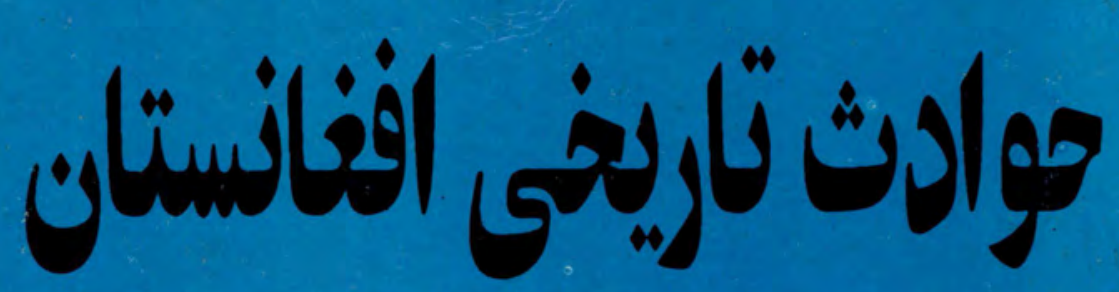

تأليف: جميل الرحمن كامكار 


\section{حوادث تاريخى}

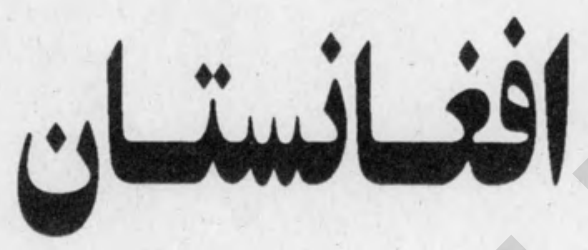

(199V 199 (از سال 199)
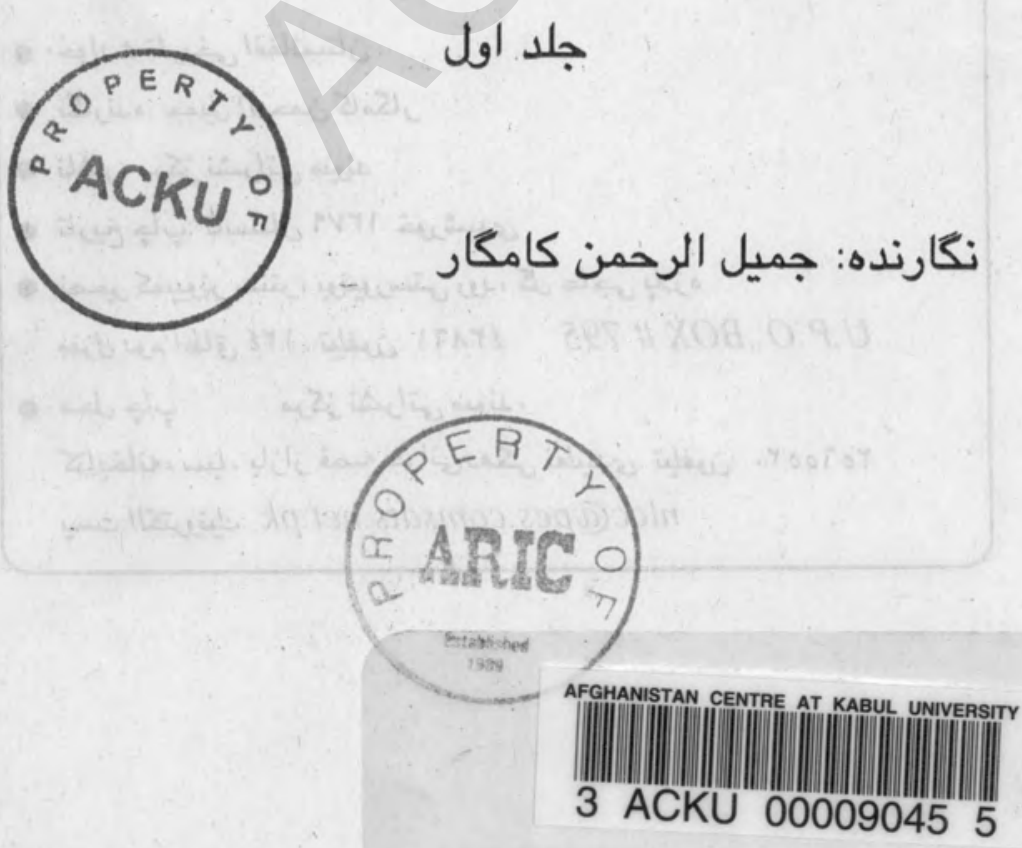


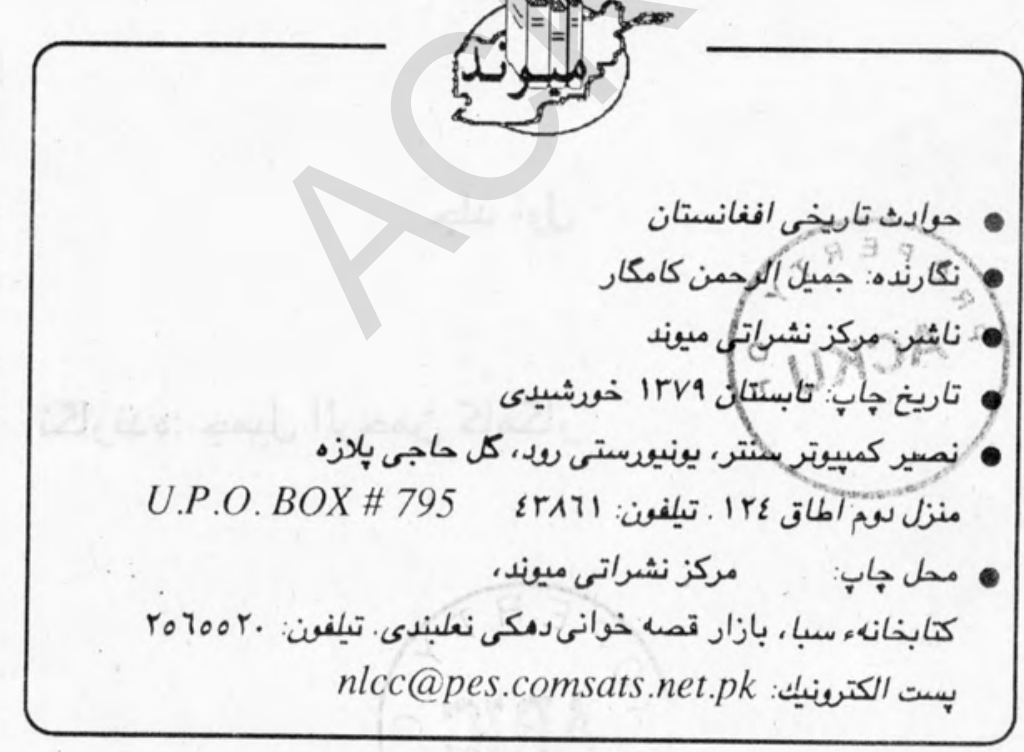



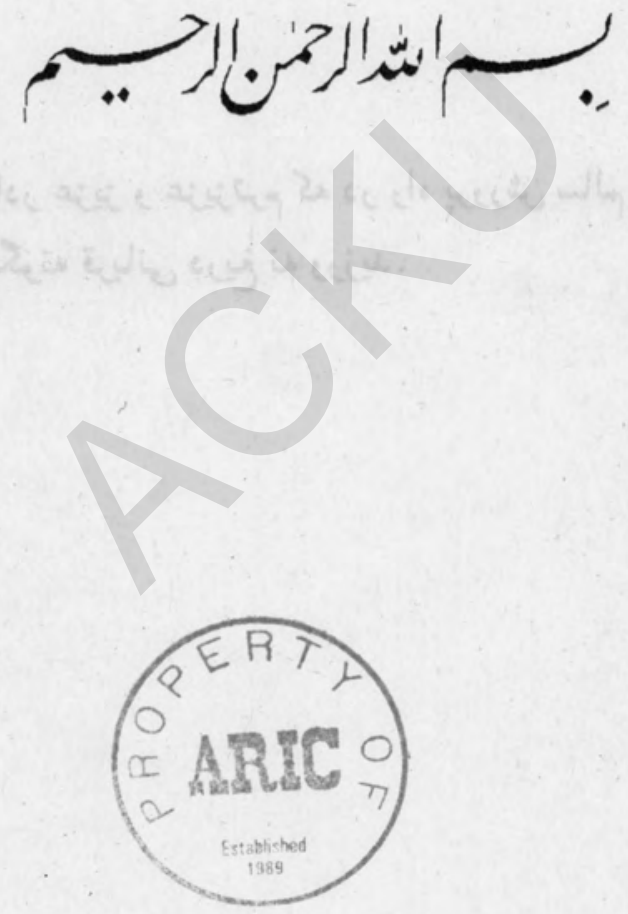
اهـــاء:

به مادر عزيز و عزيزترم كه در راه يرورش سالم فرزندان از هيحكونه قربانى دريغ نه ورزيد. 
خوانتده نهايت عزيز آنه درين كتاب ميخوانيد مجموعه يادداشت هايى هند

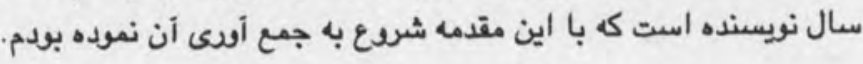

\section{يادداثشت مـالف:}

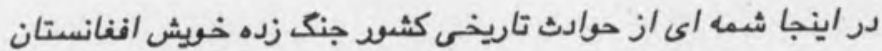

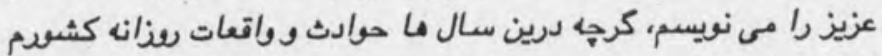

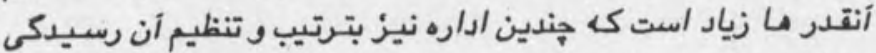

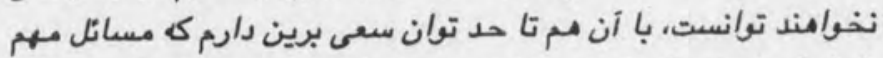

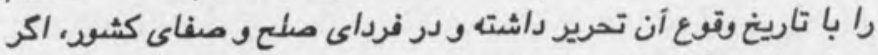

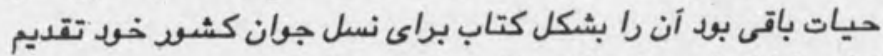

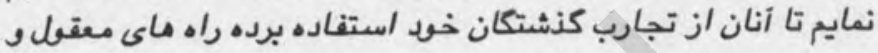
عملى زندكى را انتخاب نمايند.

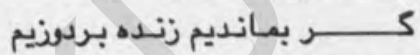

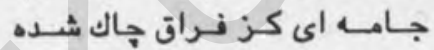

لد بمرديم عـــــر مـــــا بيـــــير

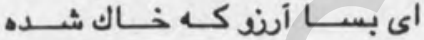

جميل الرحمن ساثل

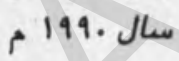

ولى متأسفانه كه فرارسيدن أن سذ خيلى طولانى شد و جنك تا هنوز در كشود عزيز ما جريان دارد.

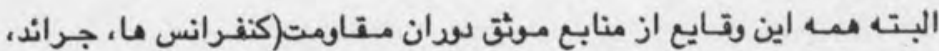

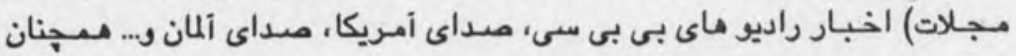

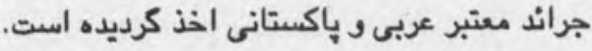

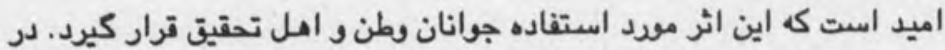

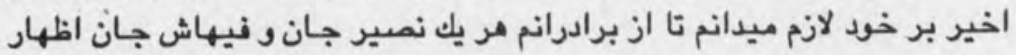

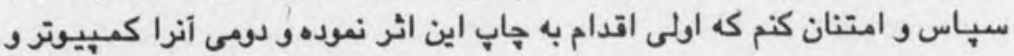

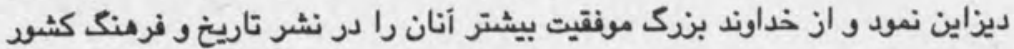




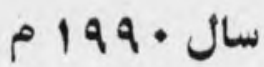

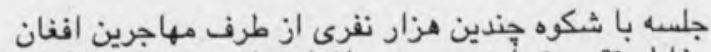

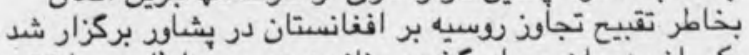

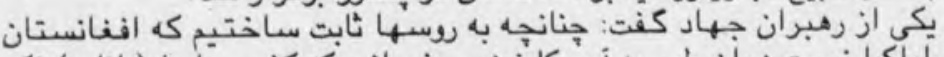

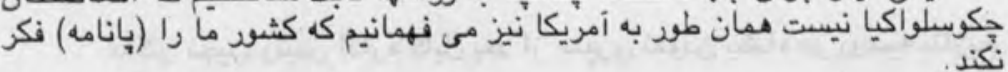

199.

$$
\text { के के }
$$

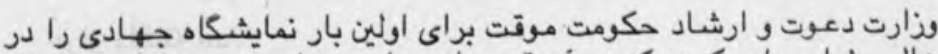

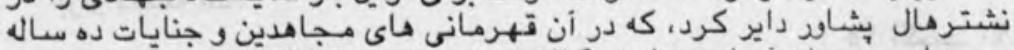

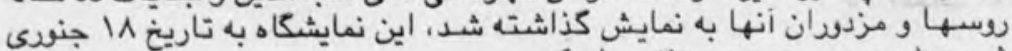
199. شروع شده بود و مدت بون هفته دوام كرد

$\$ \& 8$

قاضى نجى الأه نذير عدليه و لوى حارنوال حكومت موقت كفت: بنابه مسنوفليت

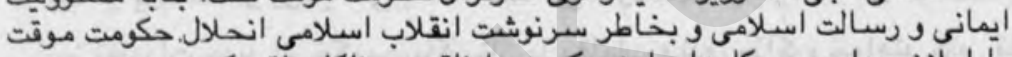

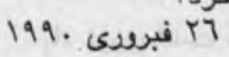

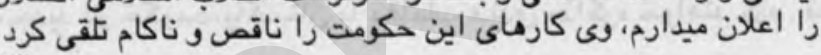

(9) 8

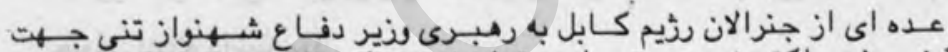

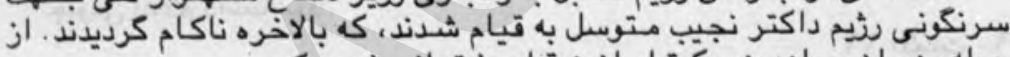
199.

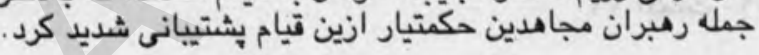

$\& 88$

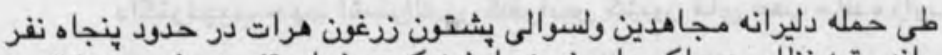

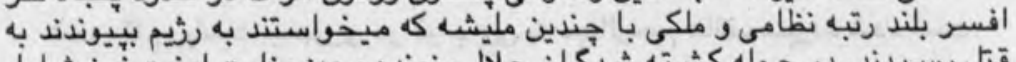

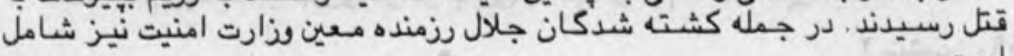
199. 7

\section{के की}

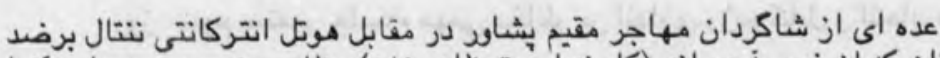

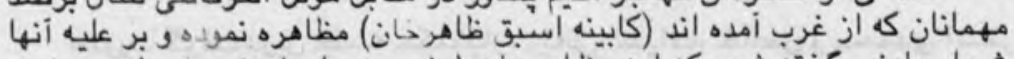

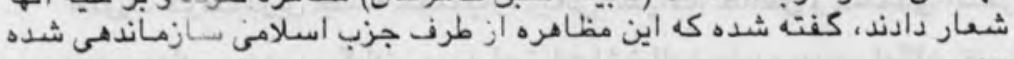

199. 


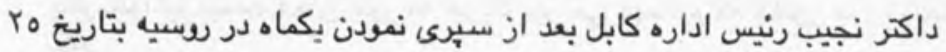

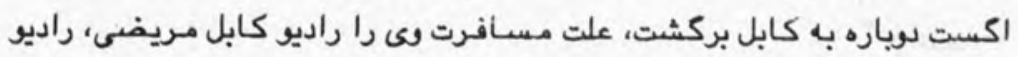

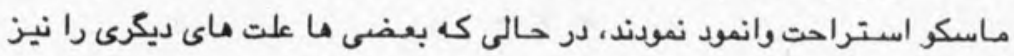
199. ابراز داشته اند. 88

راكتر نجيب بتاريخ وY اكست به هند رفت اين 'ولين سفر وكى بخارج كشود

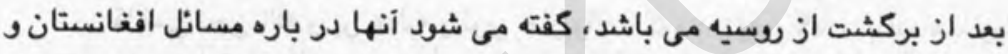

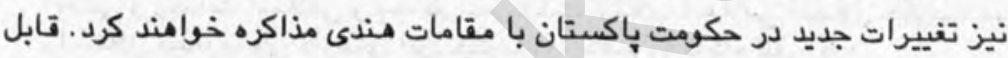

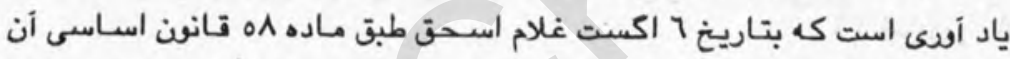

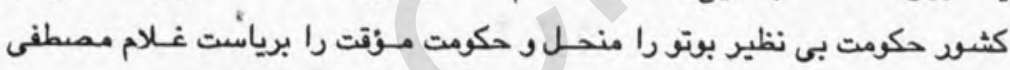
199. جتونى اعلام داشته بود بود. $\& \& 8$

داكترنجيب جهت اشتراك در كنفرانس كشود هاى عقب هانده وارن فرانسه

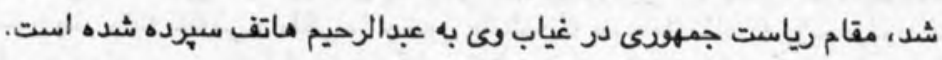

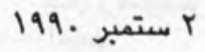

$\& 8$

رذ سوم ستمبر جلسه، مهمى بخاطر بر اندازى شذيم كابل و اتحاد مجاهدين

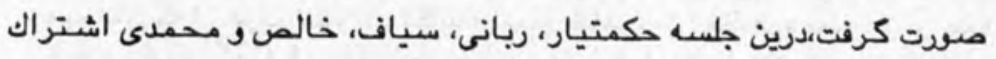

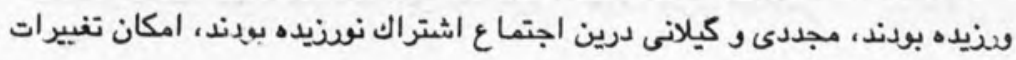
مهم در حكومت مجاهدين برده مى شود . 199. 


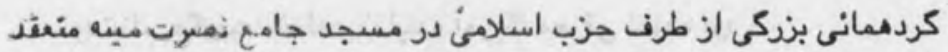

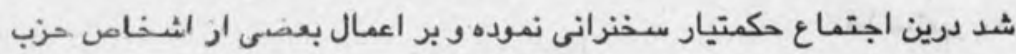

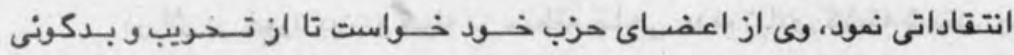

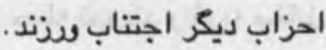

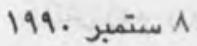

क क

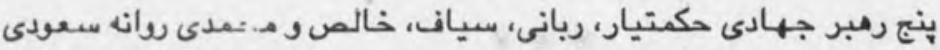
كرديدند كفته شده كه أنان بخاطر زدودن اختلافات ريات و نيز كيفيت اسقاط رئيم كابل بان

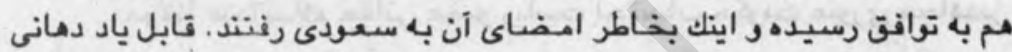

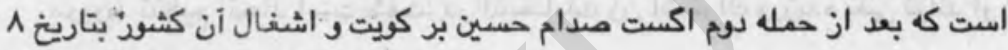

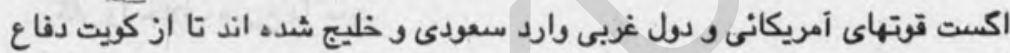

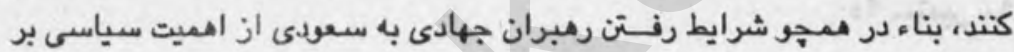

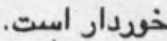

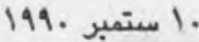

\& \&

بويس يلتسن رنيس فدراسيون روسيه از مجدىى بعنوان رئيس جمهو دعوت

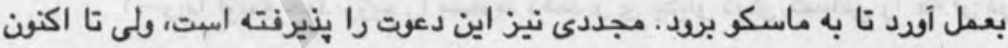

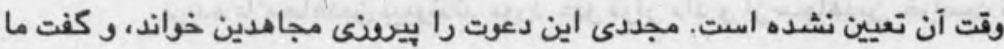
در آينده نيز خواهان روابط نيك بارسهها هستيم.

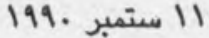

$\& \& 8$

رهبر'ن جهادى كه به سعودى رفته بودند بتاريخ عا ستمبر دوباره به يشاور

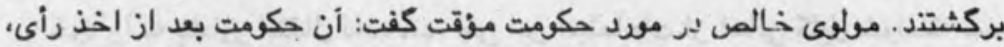

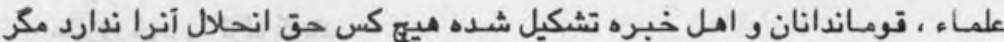

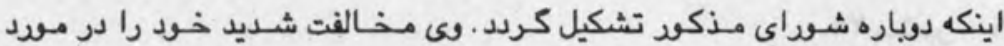

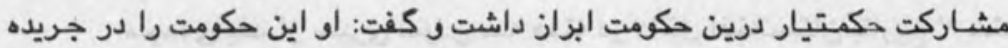


خود بنام حكومت منحله و نماينده أمريكا معرفى نموده بود.

199 19 ستمبر

در اثر بر خورد بين دو قبيله در منطقه جاجى عدهء زيادى كشته شدند. جنك

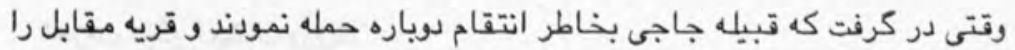

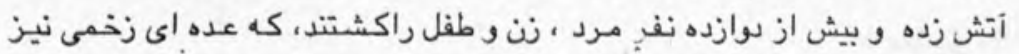

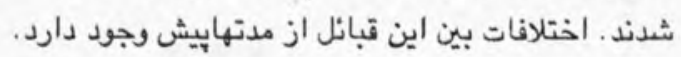

199. T. T ro

$\$ \& \$$

مولانا عبدالسلام حقانى عضو رياست احتساب حكومت عبورى مجاهدين كه أهـ

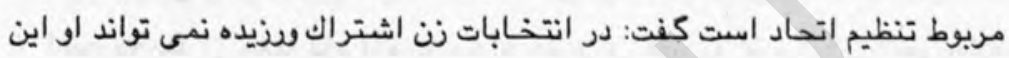

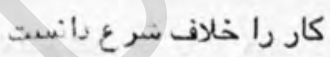

199. ro

\section{क क क}

حكــــــار به اردوى كـابل اعـلان داشــت تا يكى ازين دو راه را اختيـار نمايند:

ا-رر وقت حمله مجاهدين به كابل با ايشان همكارى نمايند.

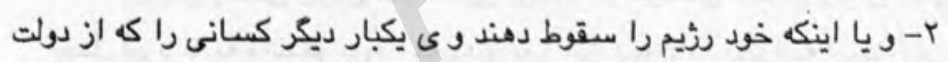

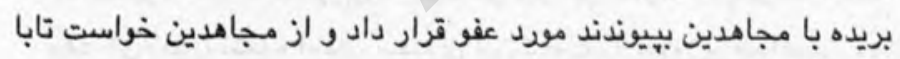
همجيو اشخاص همكارى نمايند.

199. Tr

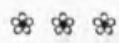

رهبران مجاهدين در حال مذاكرات اند، منظمات اففان مقيم تهران نيز دفاتر

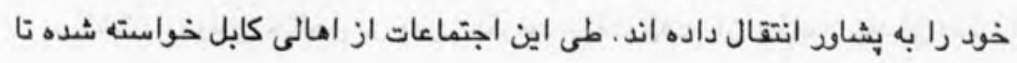
منازل خود را ترك كويند.

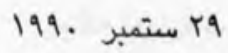

مجددى بعد از سبرى نمودن سه هفته در داخل افغانستان بتاريخ V ستمبر 
دوباره به يشاود رسيده وى با مسعود نيز ملاقاتهاى داشته بود. مجددى در مورد

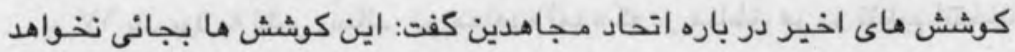

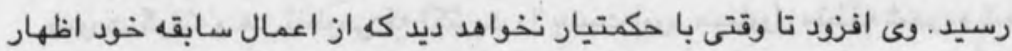
ندامت و طلب عفو كند. مجددى در مورد حمله به كابل كفت خداوند أنان را كامياب

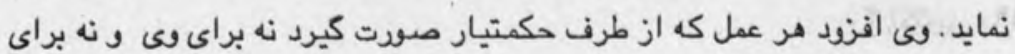

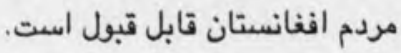

199. r اكتوبر

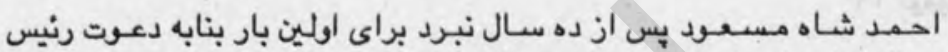

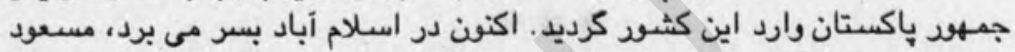

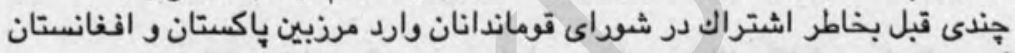
كرديده بود. 199. 19

\section{$\& \& \&$}

وذارت حج و اوقاف حكومت عبورى مجاهدين رذ ينجشنبه \ه اكتوبر فتواى

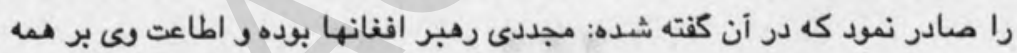

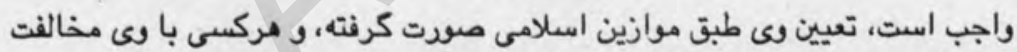

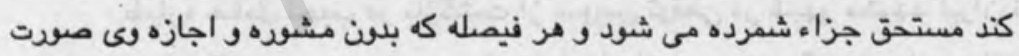
كيرد مردود و غير شرعى است.

199. 11 اكتوبر

$\$ \& \&$

رهبران جهاد به شمول خالص، مجددى و كيلانى امرزذ در منزل حكمتيار واقع

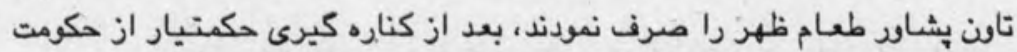
مؤقت اين اولين اجلاس همه رهبران است.

199. اكتوبر اكتو إن 
جريدهء شهادت بتاريخ ·r اكتوبر .r99 معاهده حزب، و جمعيت را كه مشتمل بر IV بند بود به نشر رساند، در معاهده أمده كه در مناطق هر دو دو تنظيم انتخابات

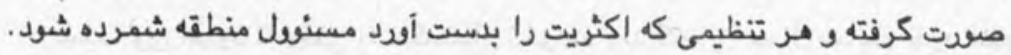

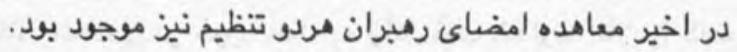

199.

داكتر نجيب رنيس اداره كابل امـرفذ وارد سويس شده ، لهى در كنفرانس كه

199. 19 بخاطر حل مسئله افغانستان تشكيل ميكردد شركت ميكند. $\$ \& 8$

رذ دوشنب ساعت 7 مببح عمليات مجاهدين بالاى كابل و جند شـبر ديكر

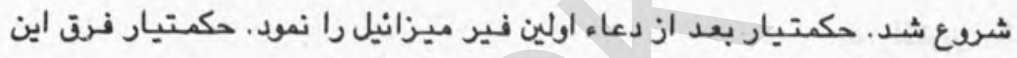

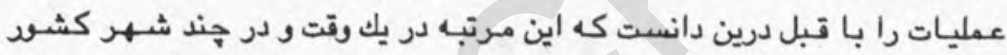
199. نومبر r. بصوت منظم شروع شده است. $\$ \&$

طياره حامل نجيب در بازكشت از سويس توتفى در شـهر مشهـد ايران نيز

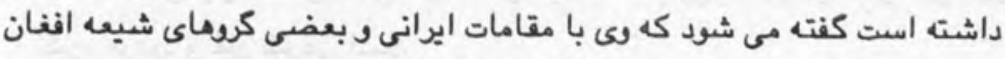

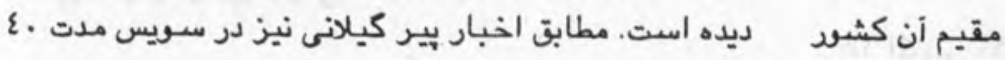
199. دقيقه با نجيب ملاقات داشته است. $\$ 8 \&$

مدرالدين أقا خان مسنول كمك هاي سازمان ملل براي باز سانى افغانعتان

199. دسمبر V بعد از تقريباً دونيم سال وظيفه مستعفى شد. 


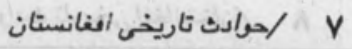

دريكى از جرايد باكستان ״نواى وقته آمده است كه براى اولين بار ملاقات بين بعضى از اعضاى ح.د.خ. و حزب اسلامى در بغداد تبل از خرج رسسها مسرت كرفته است.

199.

قطب الدين هلال رنيس سـيـاسى حـزب اسـلامى در يك كتفـرانس مطبـوعـاتى شايعات اخير نجيب مبنى بر ديدار هينت شان با حزب اسلامى را رد نمود . رى كفت نجيب از مدتها ميخواهد با ما صحبت نمايد وى اشاره به يك سياستدان باكستانى، ياسرعرفات و - نمود كه نجيب آنها را بدين منظود نزد شان فرستاده بود وى كفت جواب ما فقط تسليمى بلون قيد وشرط نجيب به مجاهدين بوده است و بس. 199. دسمبر IV 


\section{سال 1991 م}

مجددى اظهار داشته است كه امريكا از دادن كمك به حكومت مجاهدين شانه

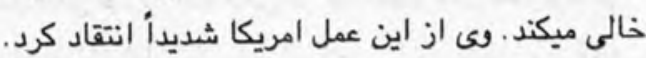

1991

به تعداد سه صد تن افغان بخاطر مشاركت در جنك خليج به سعودى فرستاده شدند. اين تصميم به موافقه همه رهبران جهادى كرفته نه شده است.

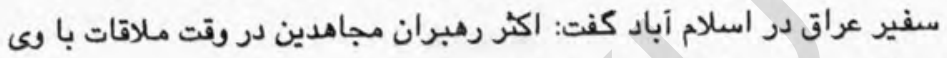

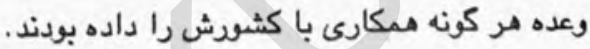

1991 فرئ

\section{$8 \%$}

سياف فرستادن مجاهدين به جنك خليج را قومانده مستقيم امريكا خواند و

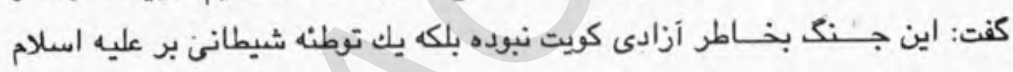
است. در ابتداء شش تنظيم مجاهدين بخاطر دفاع از حرمين حاضر شدند مجاهدين

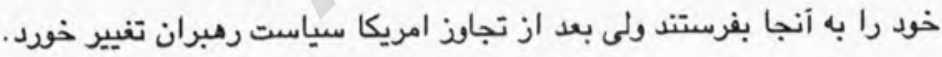

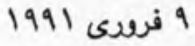

\section{कृ क क}

حكمتيار بر عملكرد عده اي از رهبرانى كه به سعودى مجاهدين فرستاده اند

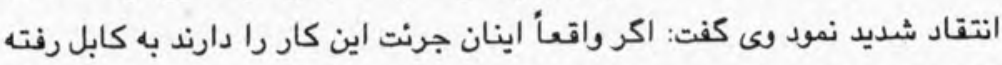
ابتداء أن را آزاد نمايند و سبس وارد ستود سعودى كردند.

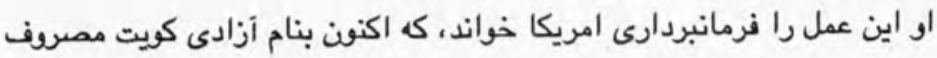
قتل و كثتار بيرحمانه مسلمانان مظلوم عراق است.

1991 فروسى 1991. 
سيد محمد على جاويد سخنكوى حركت اسلامى فرستادن مجاهدين به سعودى 1991 فروسى را تقبيح نموده و أنرا عمل ببون فاريد مايد خواند.

امرون در بشاود محملين افنان دست به تظاهرات زدند، آنان خواستار خروج

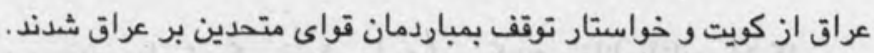

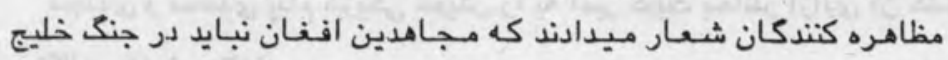

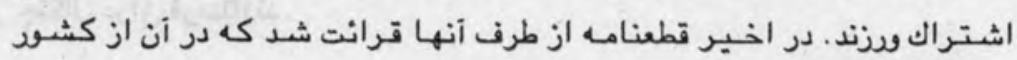
1991 19 فرئ

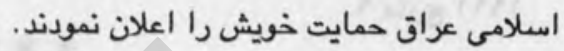

بنابه يك خبر كه در جريده هندى بنام ضانديا ابراده نشر كرديده آمده است كه

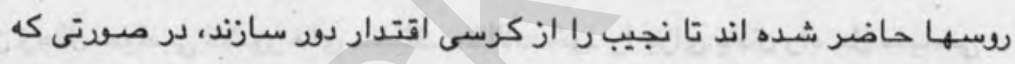

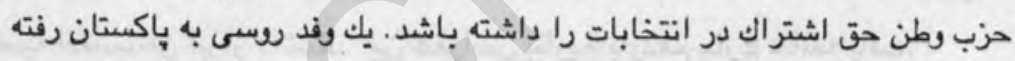
1991 Tr Tr تا با مقامات مجاهدين درين مود مذ مذاكرده نمايد. $88 \%$

شواى قوماندانان جهادى كه به تاريخ بيست و دوم دلو در جنوب غرب كشقد

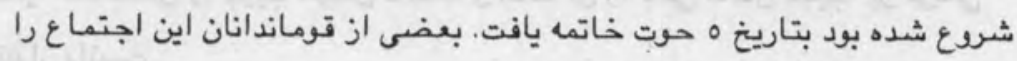
1991 فر TV تنظيم هشتم خواندند.

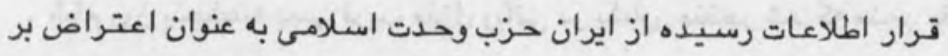

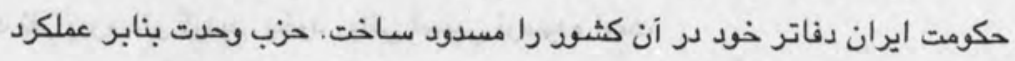

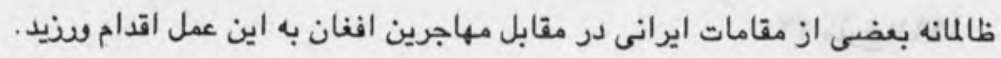

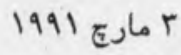


1. حوادث تاريخى افغانستان/

در جنك خليج سه نفر افغارم كثته شدند، بنابه تول يك داكتر به افنانها جنين

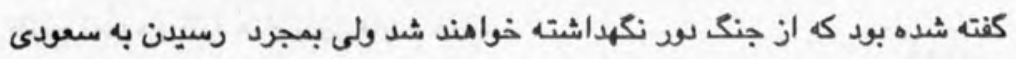
به صف اول جنك فرستاده شدند. 1991 مارع مار

مجددى و محمدى ييام تبريكى خويش را به امير كويت بخاظر آزادى آن كشود از جنكال عرات فرستادند. 1991 مارع

بتاريخ نهم مارع كنفرانس بين المللى براى حل قضيه افغانستان در موتل انتر

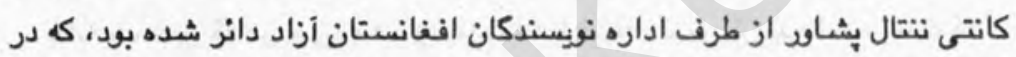

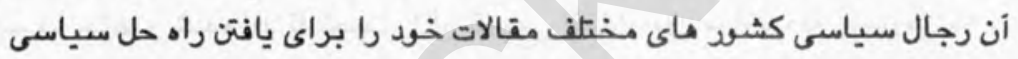
قضيه افغانستان ابراز داشتتد. اين كنفرانس بتاريخ يازدهم مارع خاتمه يافت.

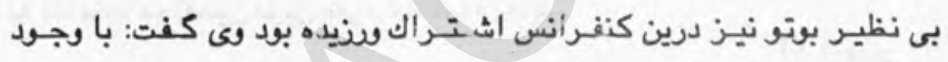

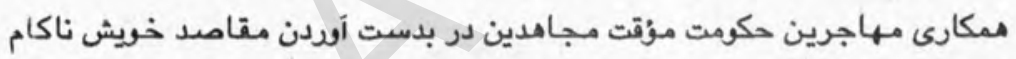

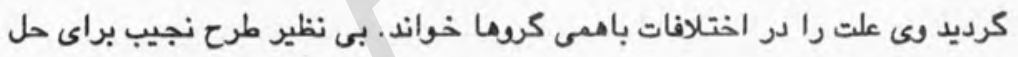

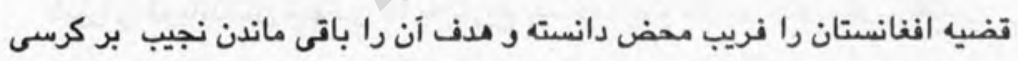
اقتدار دانست. 1991 إ مارع

شام رذ ينجشنبه بمبى قريب منزل ربانى در بشاود منفجر شد كه منبر بقتل

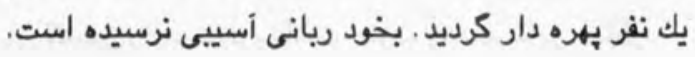

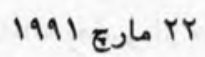


هاكتر نجيب رنيس اداره كابل خواهان بهبود رابط اقتمادى با باكستان شد،

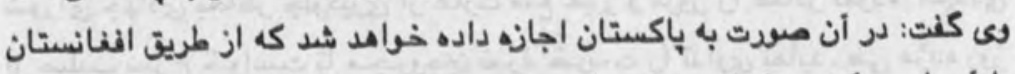

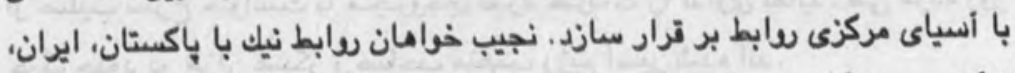

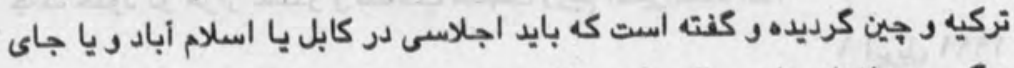

ديكرى بين افغانستان و باكستان بخاطر بهبود ورابط سياسيى سلتئين دانر كردد.

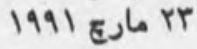

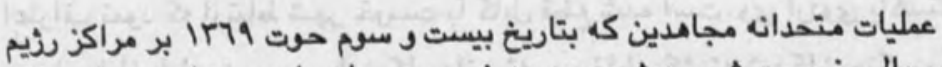

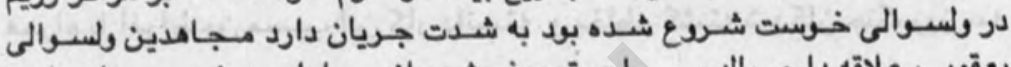

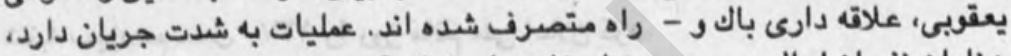

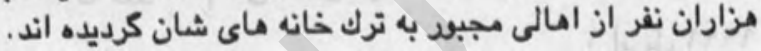

1991 E 198

مبدر اعظم شثيم كابل نفل حق خالقيار كفت: ماخواهان بهبود رابط با حكومت باكستان هستيم، لعى اين سخنان را در مجلس سناء كابل بيان داشت. 1991 عار ro

رير خارجه شذيم كابل عبدالوكيل طى نامـ اي از سر منشى مؤسسـ ملل

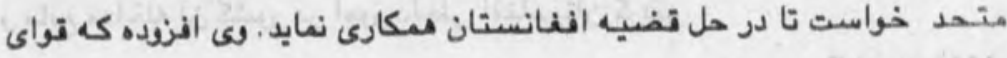
باكستانى در حمله بر شهر خوست با مجاهدين يكجا اشتراك سذيده و تواى مذكر در حمل و نتل كرقهاي مجاهدين مساعدت ميكنتد.

1991 ह ع ب.

$\% \%$

بعد از دو شغته نبرد شهر خوست بتاريخ اب مـارع بدست مجاهدين انتاد. 
شوايى جهادى بخاطر جلوكيرى از غارت منع عباد و مرد را صادر نموده. مجددى

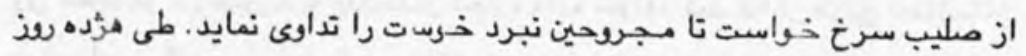
جنك حدود دو مزار عسكر و صاحب منصب رئيم اسير شده اند.

إيريل 1991

داكتر نجيب رنيس رثيم كابل با صداى كرفته و لرزان از طريق راديي كابل

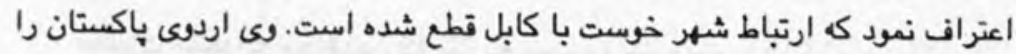

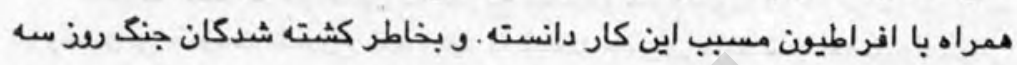
1991 ابريل شنبه سيزدهم حمل . Irv را بذ مات ماتم ملى اعلان كرد.

آقاى جمشيد ماركر سفير باكستان در مؤبسه ملل متحد در نامه اى كه به

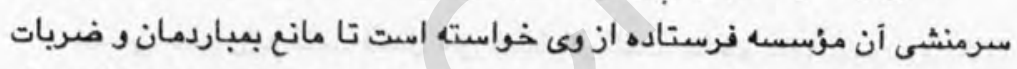

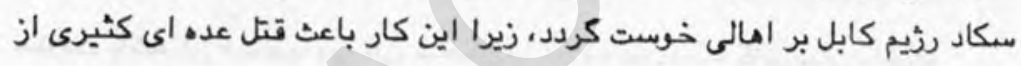
19911 ابريل

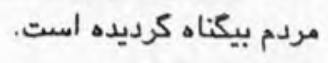

$\$ 8$

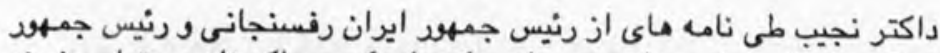

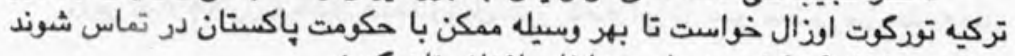
و مانع مداخله أن كشود در امورد داخلى افنانستان كردند.

1991 ايريل

$\& \&$

در شهر كراكوف بوليند كنفرانسى بخاطر كتود و فرهنك افغانستان از طرف

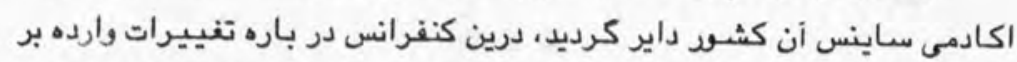

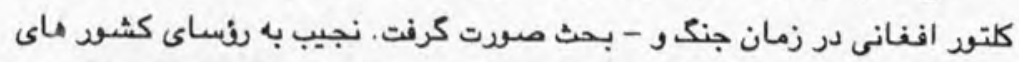

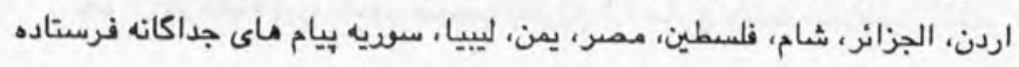


و از آنان خواسته تا از نفوذ خويش استفاده نموده مانع تجاوذ بر حريم افغانستان از طريق كشور هاى همسايه خصوصاً باكستان كردند.

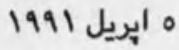

\&\&

داكتر نجيب در سلسله نامه ها اين بار عنوانى سران كثور هاى هند، نيخال،

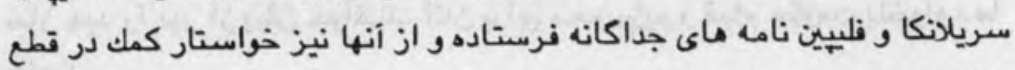
مداخلات خارجى در امو افنانستان كرديده است.

1991 ايريل

$\$ \& \$$

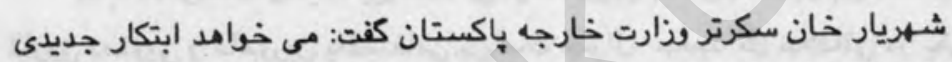

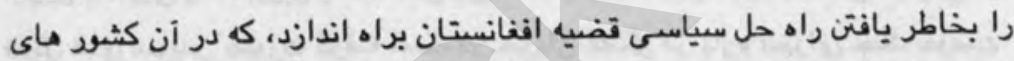

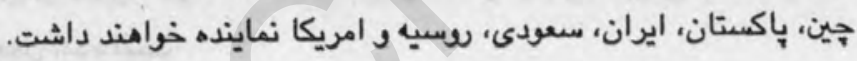
9

$\$ 88$

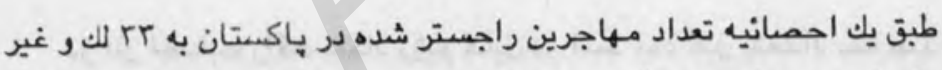

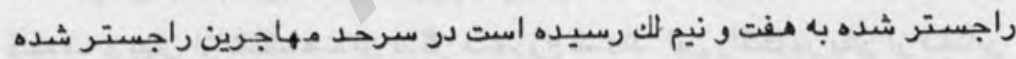

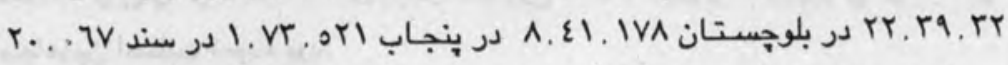

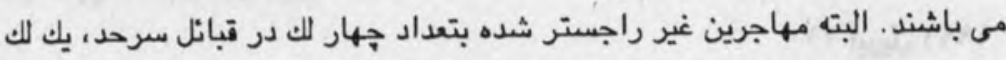

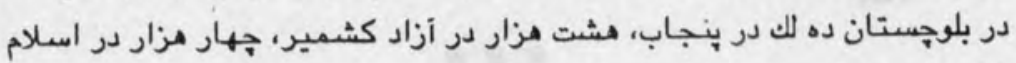
آباد و اضافه از هفتاد هزار در سند زندكى دارند.

9

\&\& \&

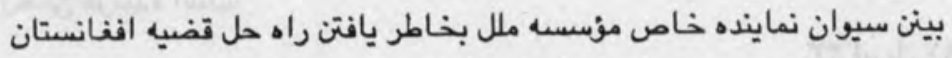

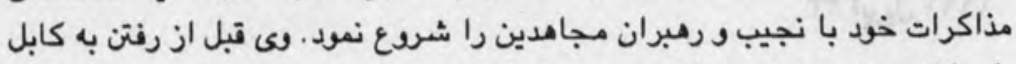
با سكرتر وذارت خارجه باكستان نيز ملاقات نمود

1991 11 11 
حكومت رسيه ابراز داشت كه بايد تضيه اففانستان در طلول مصين سال حل Sردנ. 1991 إيريل

امريذ ممادف به اول عيد فطر بود مهاجرين افغان براي بار بيست و هشتم

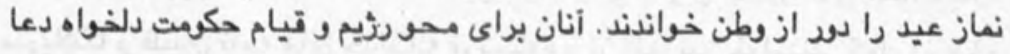
نمودند. 1991 ابريل 19

بنابه كذارشات رسيده بين عده اى از مامودين بلند رتبه كابل برياست جنرال

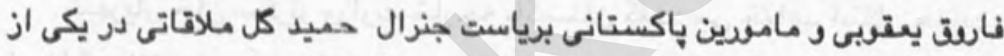

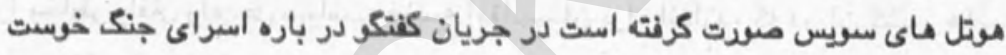
نيز مذاكره بعمل أمده است.

1991 بهريل r.

$\$ 8$

در اثر اصابت راكت سكاد بريم كابل در اسد أبأن كنر بتعداد سه مد نفر

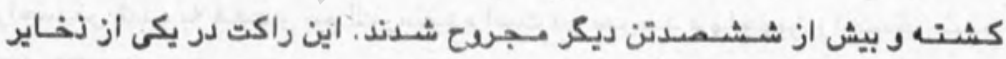
مجاهدين اصابت نموده بود بود.

1991 | 191

$\$ 8$

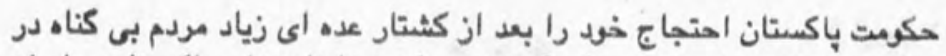

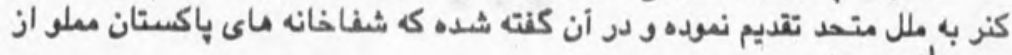
زخمئاكرديده است.

1991 ابريل 
بوليس هند اسدالل سـرى را بخاطر نداشتن باسبيرت تانونى باز داشت

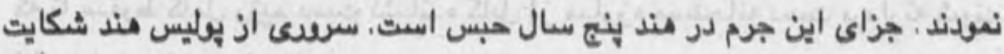

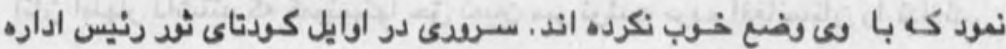

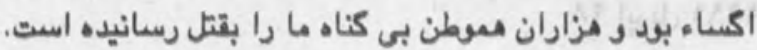

1991 ايريل

*

حكتيار سركند ياد نمد كه انتقام مردم كنر را از شئ كابل خواهد كرفت.

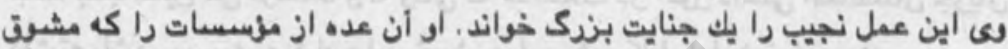
بركثت مهاجرين به كثود اند شريك جرم با نجيب دانست.

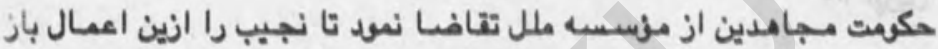

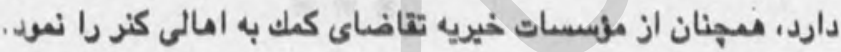
1991 بr Tr

\section{$\% \%$}

ربانى عمل طالمانه ئيم كابل در ولايت كنر را تقبيع نموده كفت: اين عمل به

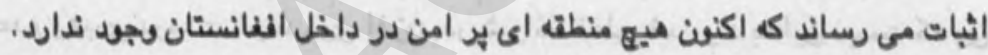

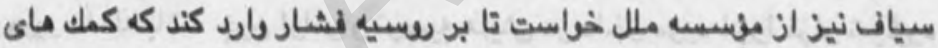

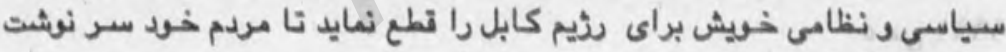
شانرا تعيين نمايند

ع 1991 ايريل

* *

شوراى جهادى رلايت بكيا مركونه معامل در مود اسراى جنك خصست را بدون مشاركت مجاهدين رد نمو، أنان كفته اند كه أسيران نزد مجامدئ مردين حيثيت مهمان را دارند و كميته مطليب سرخ ميتواند از أنان ديدن نمايد.

1991 ايريل TV 
در سيزدهمين سال سذ كودتاى ثود يكبار ديكر مجاهدين افغان اعلان نمودند

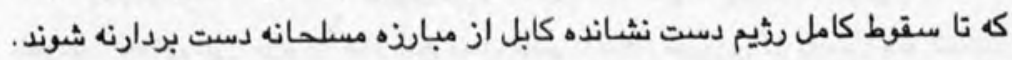

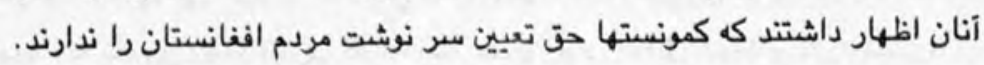

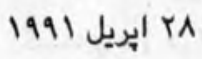

سفير روسيه در اسلام أباد كفت: بايد تضيه اففانستان از راه مذاكره حل

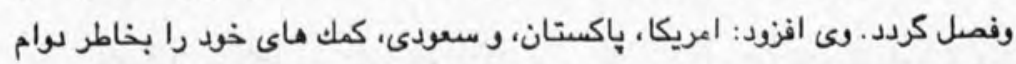
جنك بمجاهدين مى فرستند و تا وقتى كه مداخلات در امود داخلى افغانستان جريان

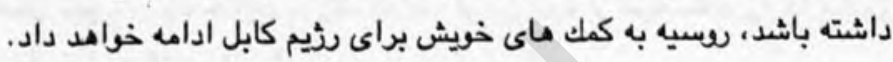
1991 ايريل

مولوى خالص طى كنفرانس مطبوعاتى در بشاور از مقامش (وذارت داخله)

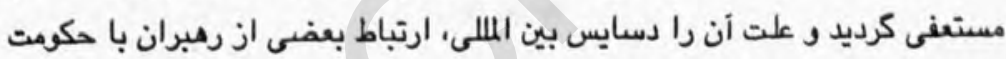

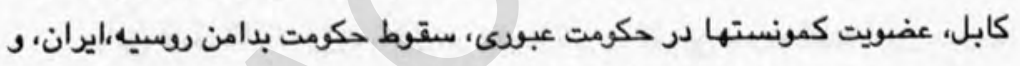

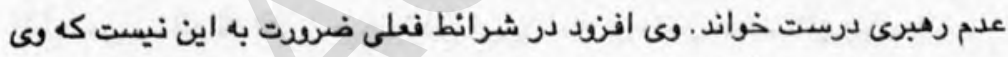
وذير داخله باشد حون اوامر و توصيه هايش در داخل مودد اجرا ترار نميكيرد. 1991 مى 0

क \& \&

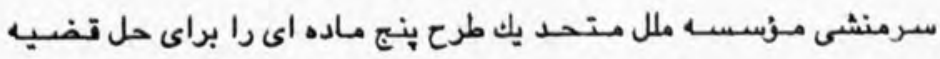

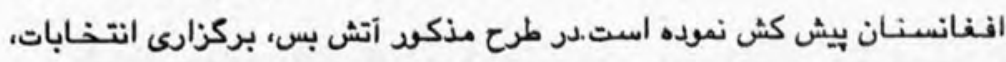

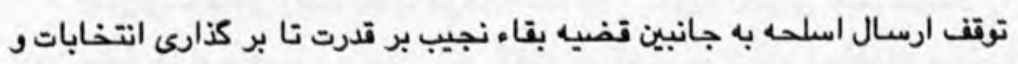
باز سانى افغانستان شامل مى باشد. 1991 r 
حكومت كابل و حكومت باكستان طرح بنج فقره اي مؤسسه ملل در رابطه بـ

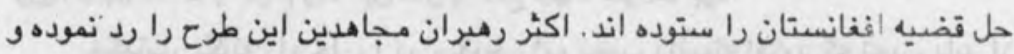
كفته اند تا وقتى نجيب بر كرسى اقتدار باشد هنين طرحها دردى را دوا نمى كنى كند. 1991 r مي

رياض احمد خان عضو بلند بايه وذارت خارجه باكستان بخاطر يافتن راه حل براى قضيه افنانستان امرون وارد ماسكو كرديد، اين دومين سفر عضدو بلند بايه بايه

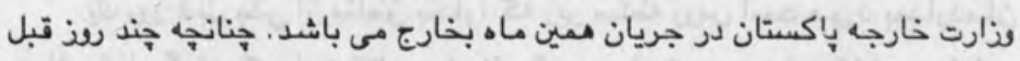
احمد ذكى بخاطر همين موضوع وارد ايران و سعودى كرديده بود . بران. 1991 م 197

$\$ \& \&$

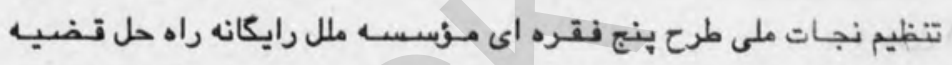

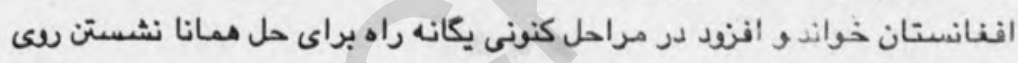
ميز مذاكره است و بس. - مان. 1991 RV RV

\section{$\$ \$$}

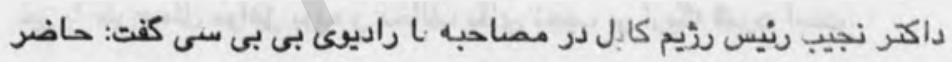

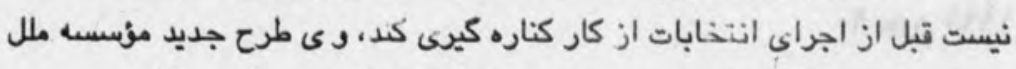

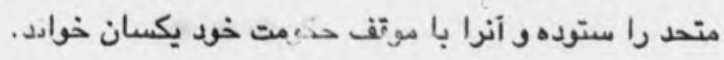

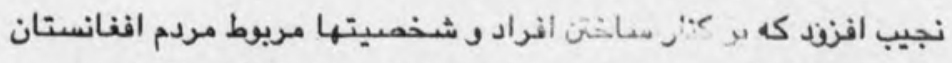
است، نجيب موقف حكومت ايرار در قبال قضيه افغانستان را مثبت تلقى كرد.

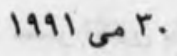

988

دكمتيار طس كنفرانس مطبوعاتى طرح جديد مزسسه ملل را يكطرنه وخلاف

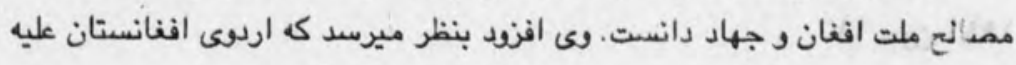


ثديم كابل دست به تيام زند اين كار به نفع جهاد خواهد بود.

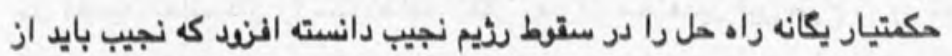

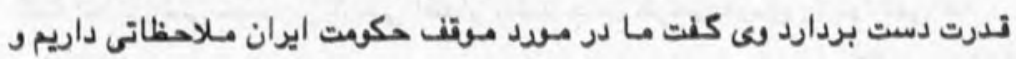

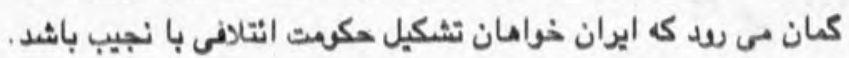
1991 riv

يك سذ تبل يكى از مناطق بخـارا كه زير سلطه سس است ميدد بمباردمان

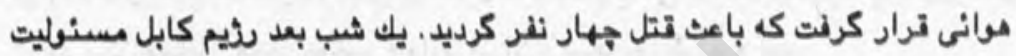

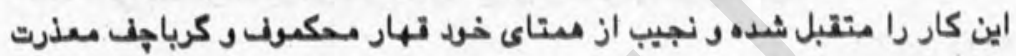

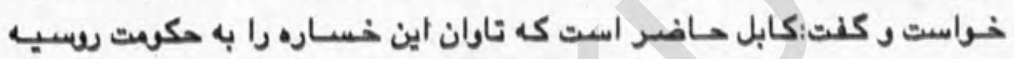

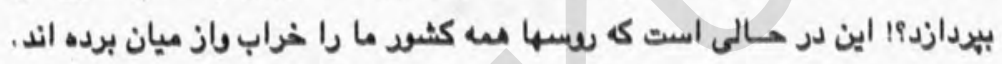

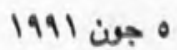

क क

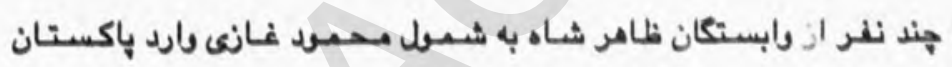
كرديدند، شخص مذكود بعد از ده سال ويزاي باكستان را حاصل نمو. . ظاهر خان

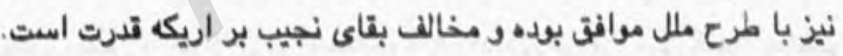
9

محمد عبدالحليم موسى لخير داخله مصر كفت: متهبين تضاياى سياسى در

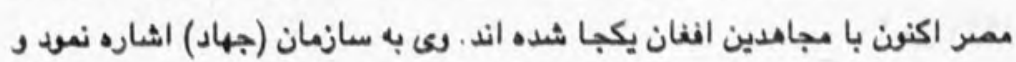
كفت اكثر اعضاى أن در افغانستان اند و در آنجا ترينت شده و بخاطر عمليات بـ بـ بان ممر بر ميكردند.

11 
رحمت الله مرتفرهى با شش رمبر شيعه انفان مقيم ايران وارد باكستان

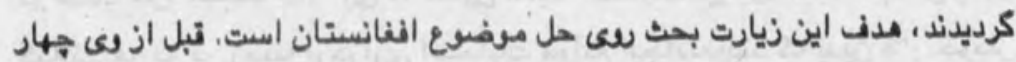

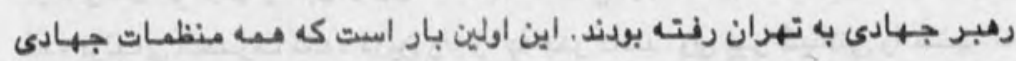
بشمل شيع و سنى و- يكجا سلى حل تضيه افغانستان محبت مى كتند.

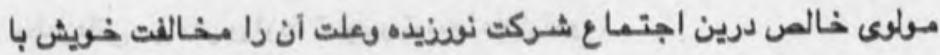
كرماه ومابى و شيع دانست است.

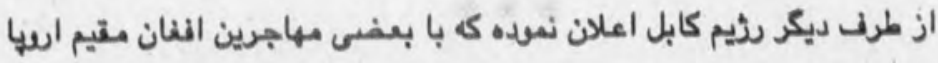

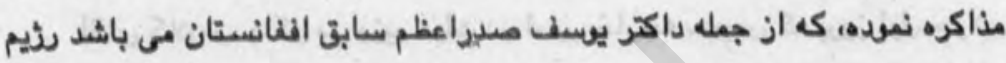
كابل با جلب و جذب اين اشخام ميخوامد براى خود مشرعيتى بدست أرد. | 19

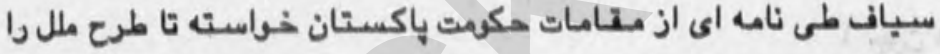

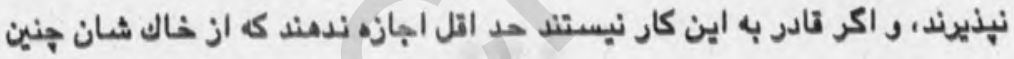

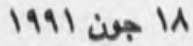

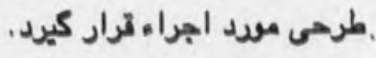

بيرك كارمل بعد از بنج سـال برده تققيف در رسيك بوباره به كابل بركشت

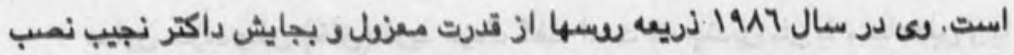
ان مقام كرديد. كارمل سوار بر تانكهاى سعى فارد كابل كرديده بود. 1991 r.

احمد شاه مسعود كفت: مجاهدين سو باره شهر خواجه غار را بدست أوردند، اين منطقه جندى قبل بدست مجاهدين افتاده بود ولى شدت بمباردعان مجاهدين را

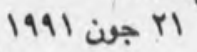

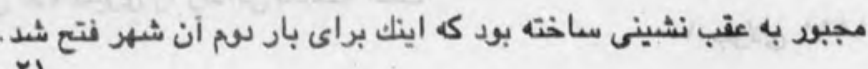


فاروق أعطم دزير نمليم و تربيا حكومت عبورى و معاون تنظيم هحاد سلى ان هر

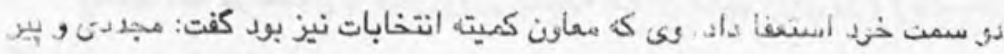

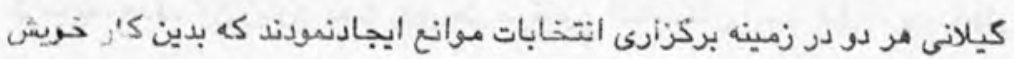

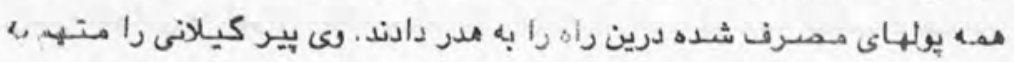

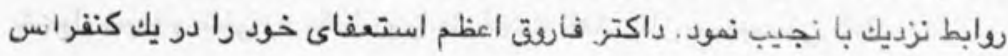

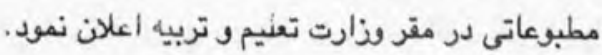

1991

$\$ \&$

أقاى كلاوس جاكو بى وذير دولت در امور خارجه سويس كه بريذ اول جولاي،

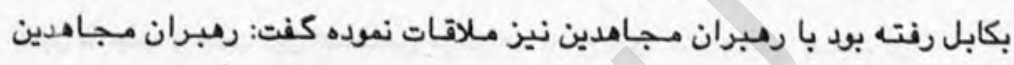

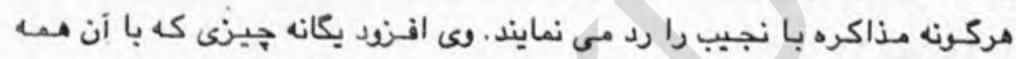
رهبران نظر متفق دارند شركت نكردن نجيب در حكومت أينده است.

1991 7

$8 \%$

مؤسسه عفو بين الملل از شئم كابل خـواست تا لست كسانى را كه در طول

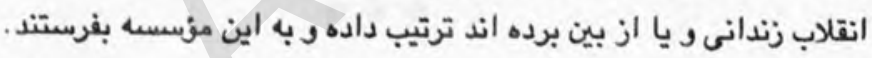

991 جن 919

$\notin \approx$

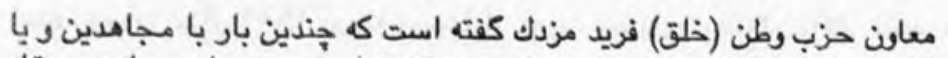

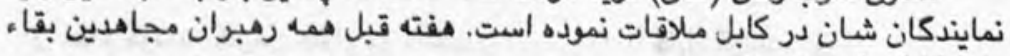
1991 انو 191. كثيم كابل را رد نمودند.

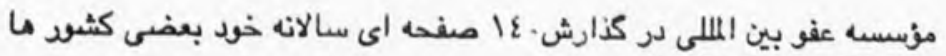

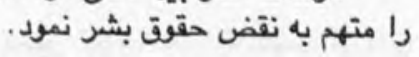

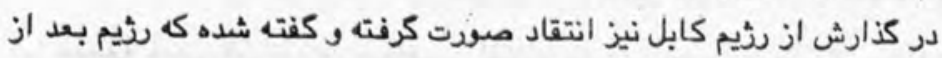

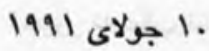
كودتاى تنى عده كثيرى را زندانى ساخته است. 
محمـد يونس قانونى نمايند هـ شـواى نظار طى كنفرانس مطبوعاتى كفت

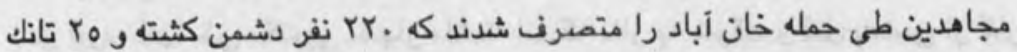
تخريب كرديده است . از مجاهدين .r نفر شهيد شده اند راند 1991 جول Tr

سه تن از رمبران مجاهدين حكمتيار، ربانى وسياف طى اعلاميه ايى ابراز

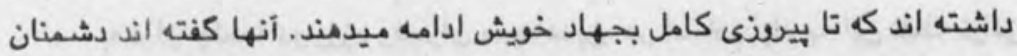

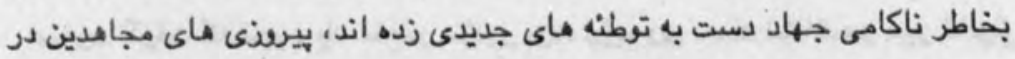

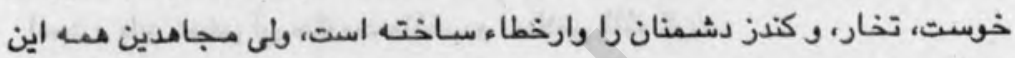

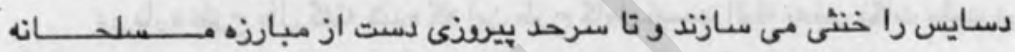

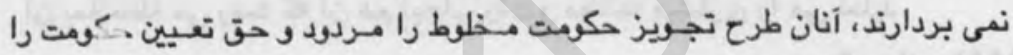
1991 إ مريوط مجاهدين دانستند بردان.

ببرك كارمل كه يكماه قبل به كابل فرستاده شده بود در اولين مصاحبه خويش

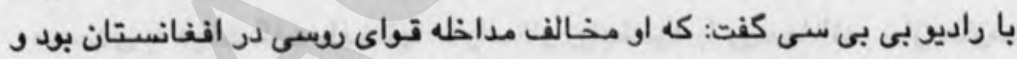

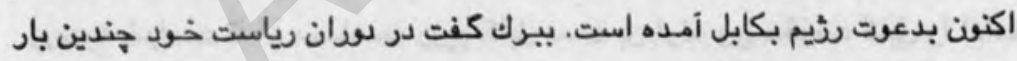

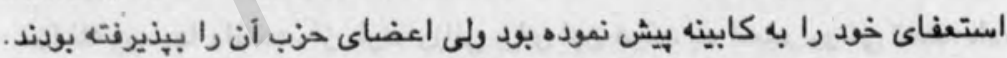

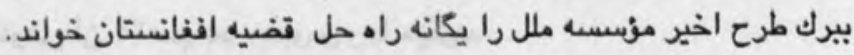
1991 - 17 17

مؤسسه مبليب سرخ همكاران خود را از افغانستان خارج ساخته و اعلان

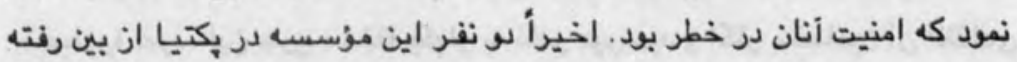

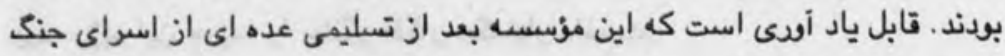
19

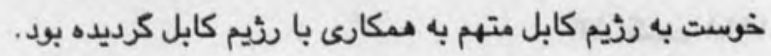


مؤسسه نجات بين الملى IRC كلك هاى خود براى الفانستان دا بحال تعليق

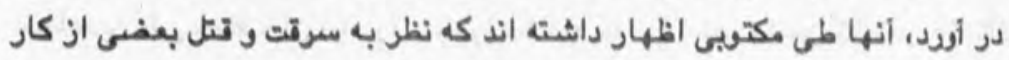

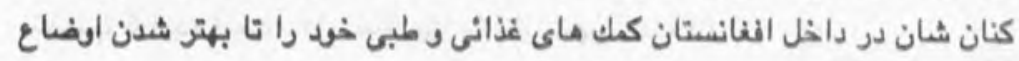

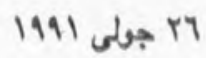

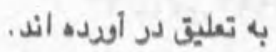

\%

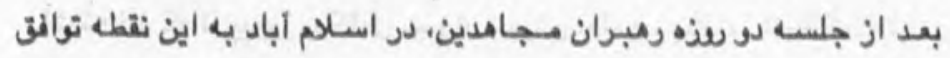

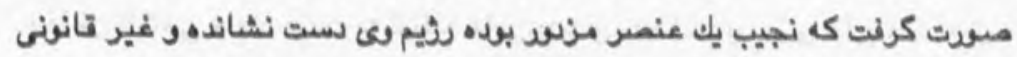

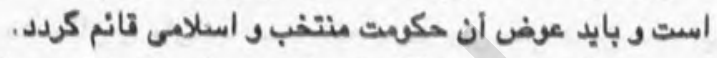

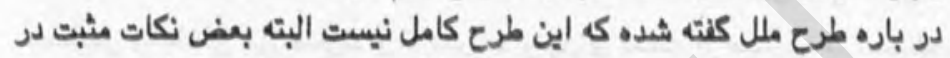

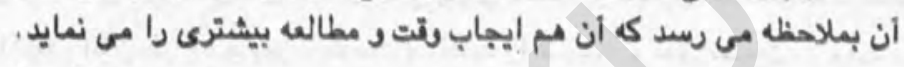

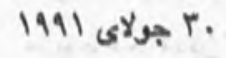

\section{*}

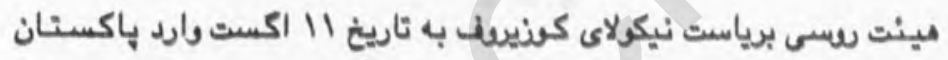

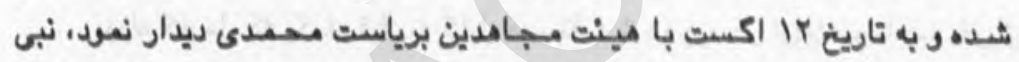

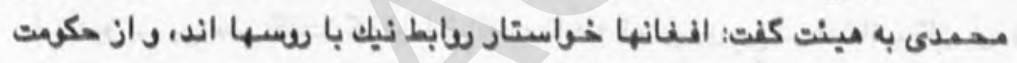

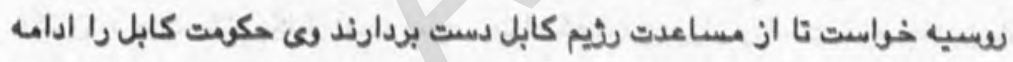

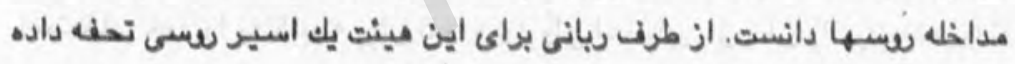

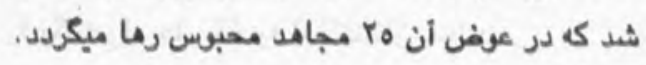

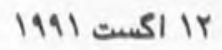

$\%$

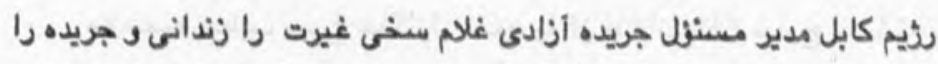

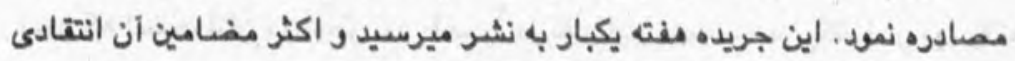

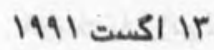
بود . ثيم اين جريده را بيانكر افكار حكمتيار دانست. 
مذاكراتى بين رسهبا و مجبامدين شوداي نظار در منطته اشكاشم صورت

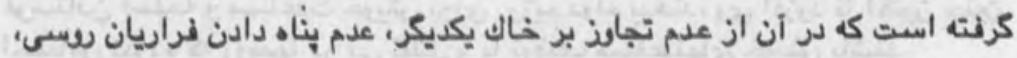

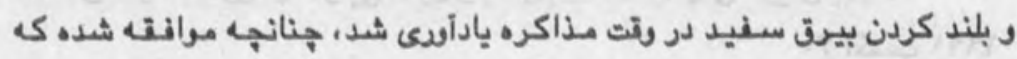

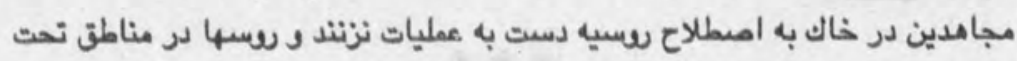
كنترل شوراى نظار كارى نداشته باشند.

1991 Ir Ir

$\notin 8$

مجددى از بويس يلتسن خواسته است تا مساعدت خويش به ثذيم كابل را

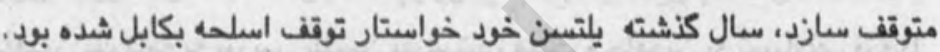

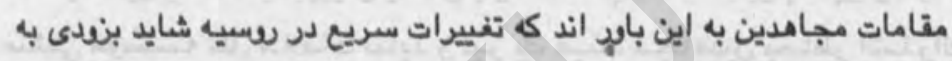

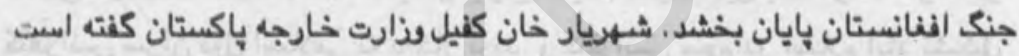

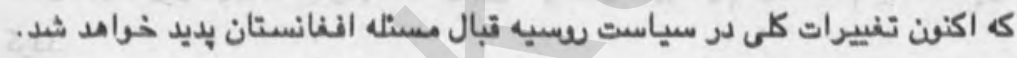

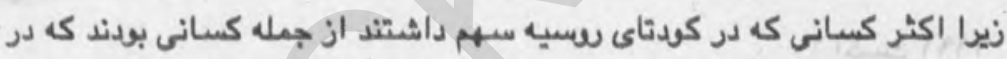

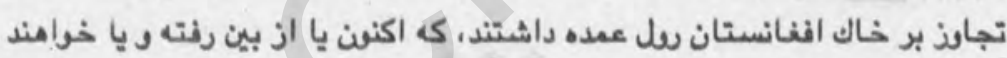
رفت.

1991 Tو

$\% 8$

سه تنظيم مجامدين حزب، اتحاد اسلاهى و حزب خالص علت عدم اشتراك

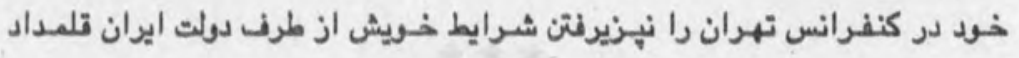

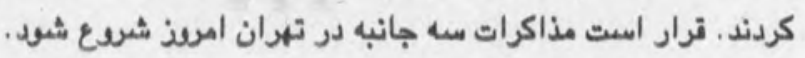
1991 TV

$\Leftrightarrow \&$

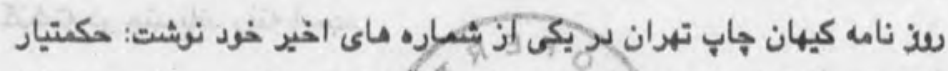

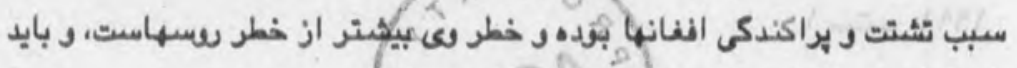

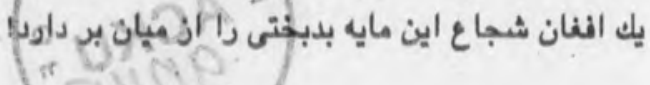

A 1991 191 


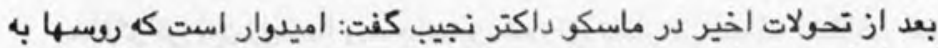

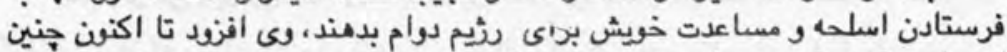

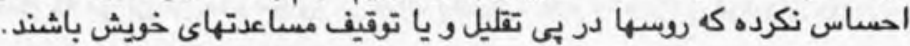

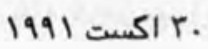

كنفرانس تهران كه در آن رمبران مجاهدين، مقيم ايران و باكستان اشتراك

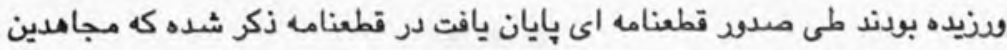

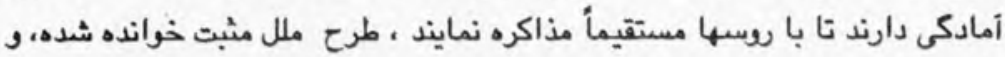

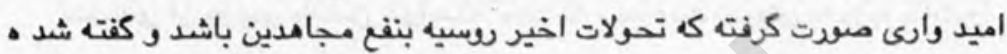

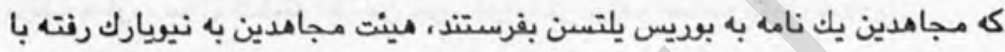

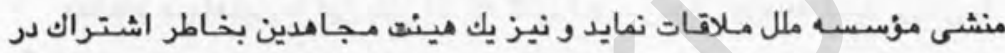

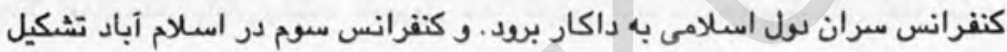
كردد. 1991 isir.

مولى جميل الرحمن رهبر جماعة الدعوة اللى القرأن و السنه كه نام اصلى اش

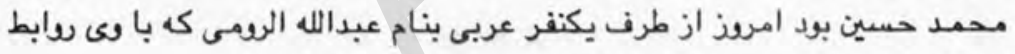

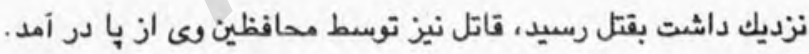
. 1991 اكست

دييلوماتهاى خارجى در كابل مى كويند كه بعد از تدولات اخير روسيه تقريباً

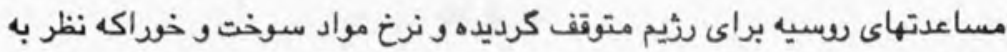
1 ستمبر 1991

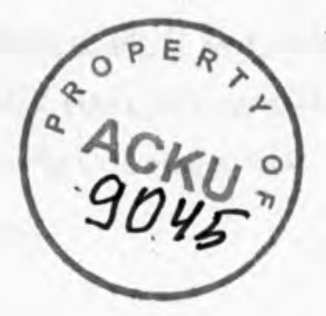
كنشته دو جند بلند رفته است. 


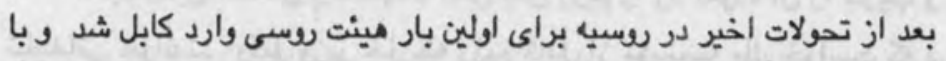

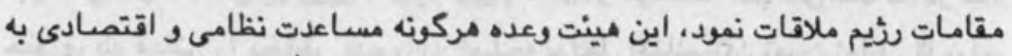
رثيم كابل را نمود.

1991 (19 1.

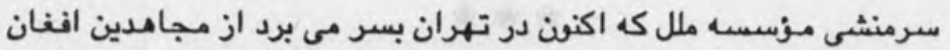

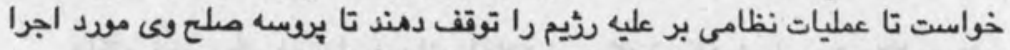

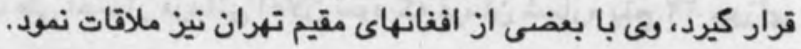
1991 إ ستمبر

$\$ \&$

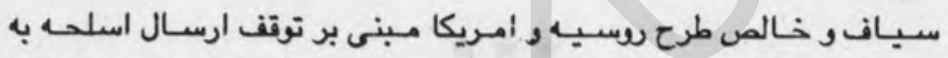

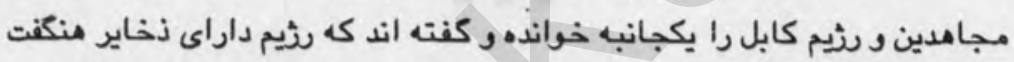

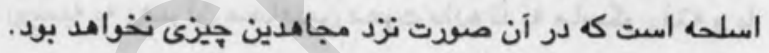
حكمتيار ازين تمميم استقبال نموده افنود همين دادن جهارماه فرصت خيانت به جهاد دانســـه ميـشود درين كـار بايد به هيـه جـناح حنين فرصت داده نمى شد.

1991 10 1910

$\$ \&$

داكتر نجيب در ييام راديو تلويزيونى خـويش از هم اطراف حتى ظامرشاه خواست تا از تمميم سب و امريكا در مودد برقرارى صلح همكارى نمايند. او از قوماندانان داخل خواست تا در مناطق مربوطه خويش اوربند را مراعات نمايند تا تصميم مذكور عملى شود. نجيب افزود بايد از استعمال اسلحه ثقيل خود دارى مريى شود . وكي وعده داد كه حكومت أينده به كشود ماى ممجوار ضردى نخواهد رسانيد. 1991 1917 17 


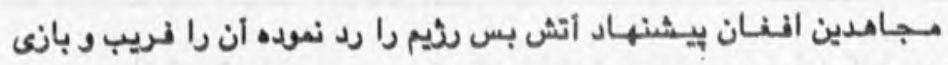

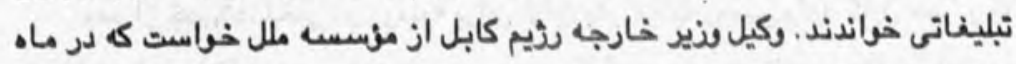

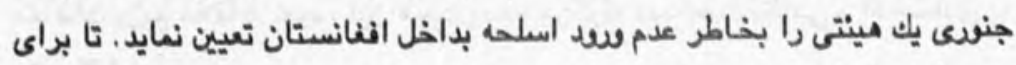

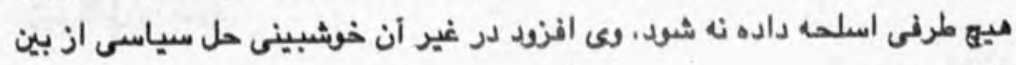

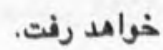

1991 19 19 19

$\$ \%$

داكتر نجيب طى اصدار فرمانى اعلان نمد كه فرمان شماره بنج rr جوذاى

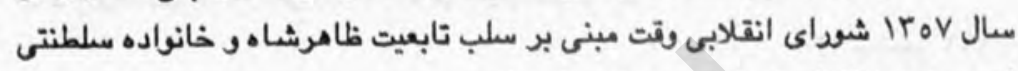

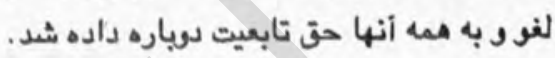

1991 19

$\$ 80$

وذارت خارجه برسيه به رمبران مجاهدين دعوت داده تا به ماسكو رفته و با

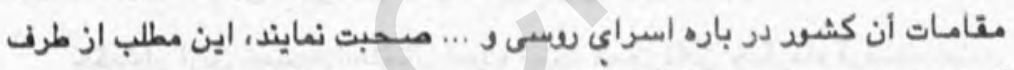

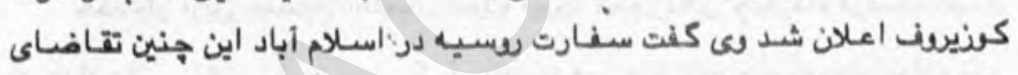
1991 11 ستمبر

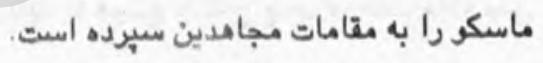

رد كذشته يك سازمان جديد بنام حزب أزادى در كابل اعلان وجود كرد، اين

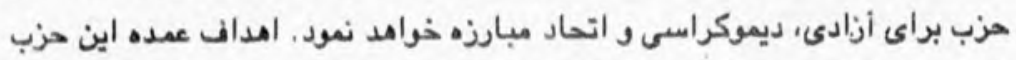

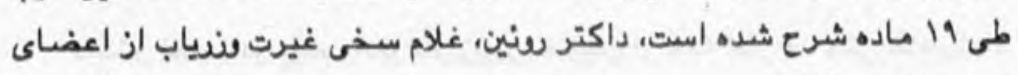
1991 11

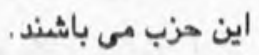

$\$ 8$

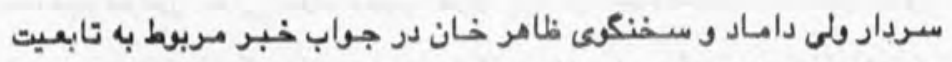

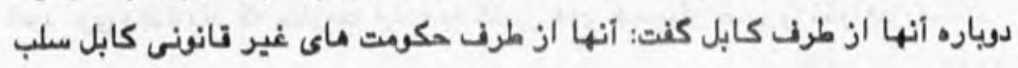


تابعيت شده بودند كه نه در آن وقت و نه اكنون اعلان همجيو اخبار مود تبول ما

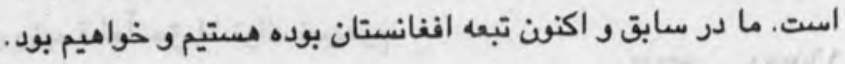

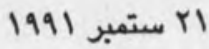

\& \& \&

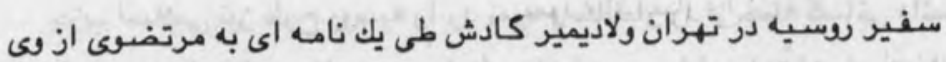

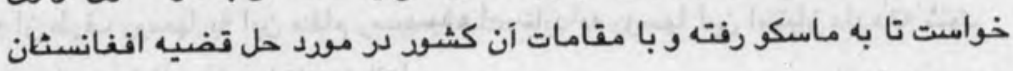
ع 1991 ستمبر صحبت نمايد.

$8 \%$

يك مينت مجاهدين برياست مجددى وارد نيويارك شد. منظمات حزب اسلامى،

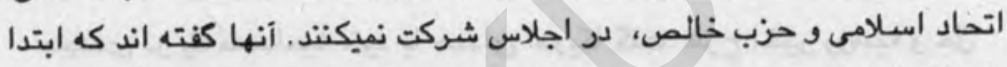

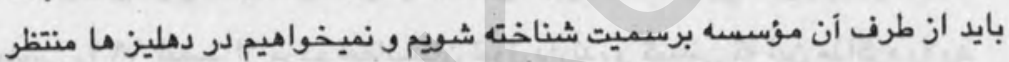
بمانيم. بإن

\section{1 ra}

داكتر نجيب طى كنفرانس مطبوعاتى از مجاهدين خواست تا در مناطق تحت

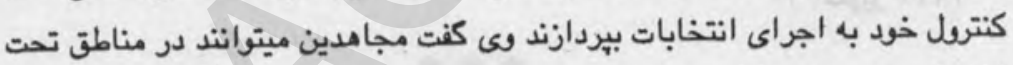

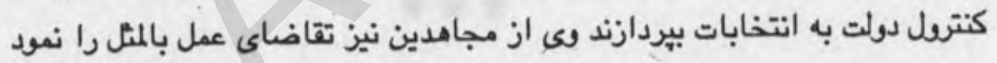
1991 r r r. r.

لذير خـارجه روسيه بويس بنكس در ملاقـات خويش با مجددى در نيويارك براى حل قضيه افغانستان حنين بيشنهاد نمود: ا- ذريعه يكى از رهبران مجاهدين حكومت انتقالى تشكيل كردد كه رمبر ئر حكومت از جمله مجاهدين و صدر اعظم أن خالقيار باشد.

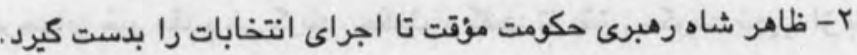

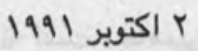

\&8 8

سياف، ربانى وخالص طرح اخيز روسيب را يك توطنه عليه جهاد خواندور 
كفتند ربسها ميخواهند ازين طريق رثيم كابل را بر ما تحميل كتند، ما را حكومت

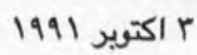
أينده بـ اعضاى رثيم قطعاً حق اشتراك نميدهيم.

$\$ \&$

حزب اسلامى نيز طرح رسسيه را رد نمود و خالقيار را از جمله كسانى دانسته

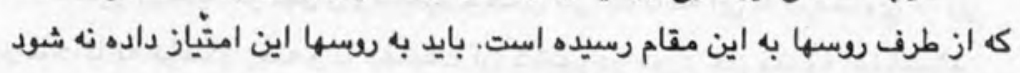
كه در امور داخلى ما مداخلت نمايند. 1991 اكتوبر

$\$ 2$

مجددى در يك ممناحبه خود با مداى امريكا كفت: طرح اخير رسسيه وحل

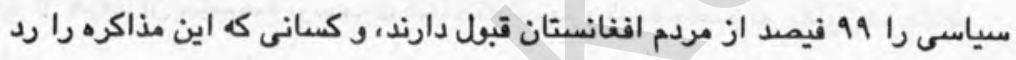

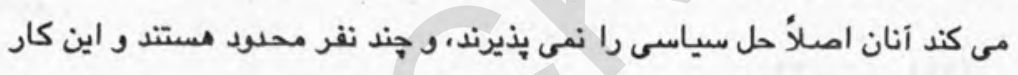

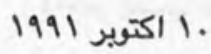
أنها ما را از رفتن به رسيه باز نميدارد. $\$ \&$

بنا بـ كذارش هاى نشر شده از طرف منابع جهادى عمليات وسيع مجاهدين 1991 ا اكتوبر

حكمتيار طرح اخير رسسيه را رد نموده كفت هركشى كه اين طرح را بيذيرد

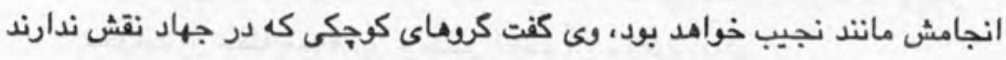

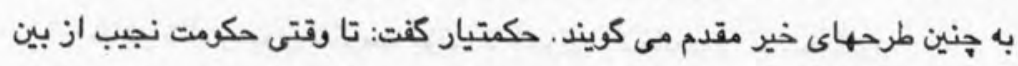
نرفته است مجاهدين اسله خويش را بر زمين نخواهند كذاشت كرئ.

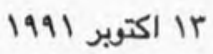


سفير روسيه در كابل بوديس با ستوخـف كفت: اكنون ضروت ستخت به

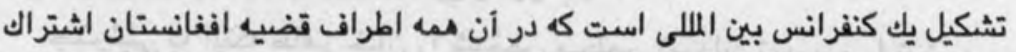

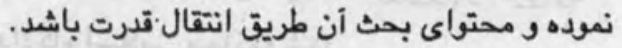

1991 1 199

و دير صافى ونير هوانى ملكى ثثيم كابل در يك مصاحبه كفت: اعضاى بلند

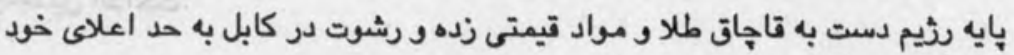

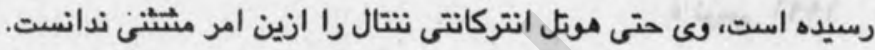

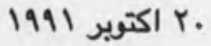

\section{$\notin 8$}

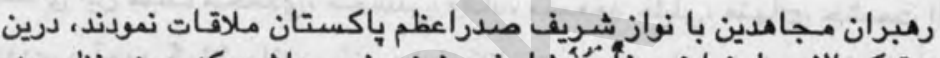

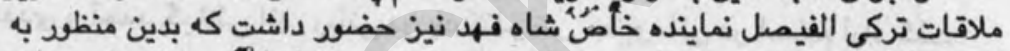

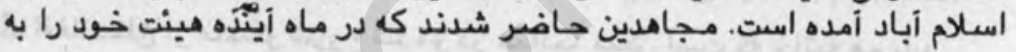
رسيه بفرستند.

1991 ع 191

$\$ 8$

محمد ظاهر بادشاه سابق افغانستان در يك سوء قصد مجروح شد ريى در

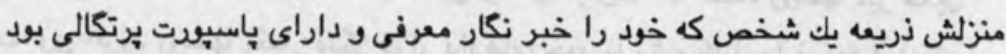
با ضرب جاقو مجرع شد درئ.

ع نومبر 1991

$\notin \notin$

مجددى حمله بر ظاهر خان را محكوم و تآّر عميت خود را ابراز داشت صى حسى

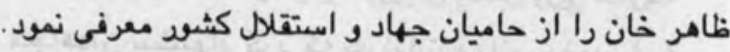

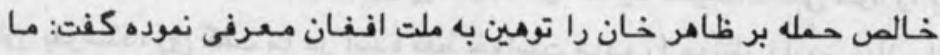

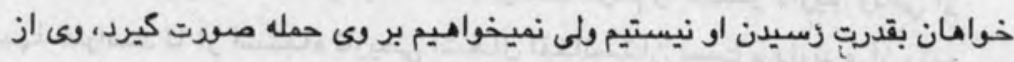




\section{r. رادث تاريخى افنانستان/}

حكومت رم خواست تا شخص حمله أود را جزا دمد.

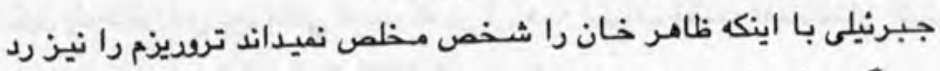

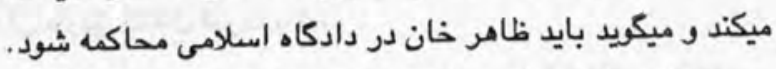

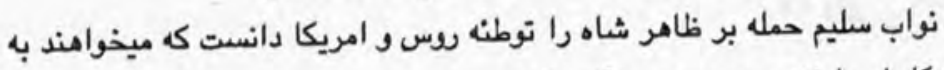
اين شكل او را نزد مردم محبوب كردانتد.

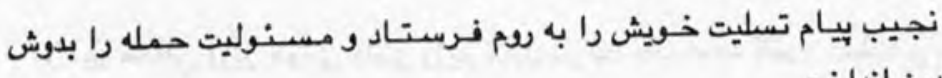

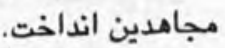
م نومبر 1991

وفد مجاهدين برياست ربانى وارد سعودى شد تا از آن طريق به ماسكو برند

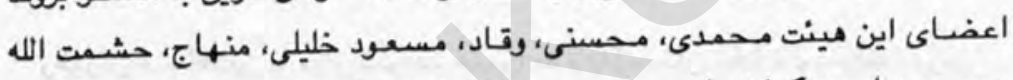

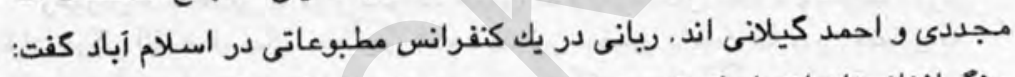

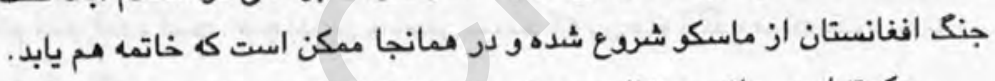

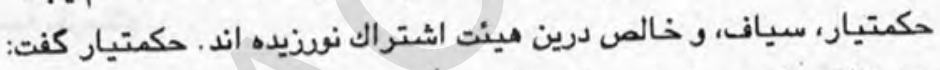

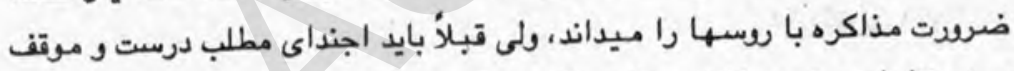

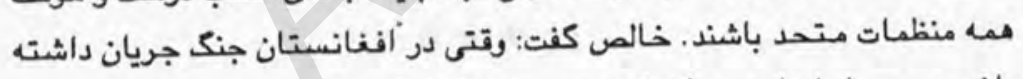

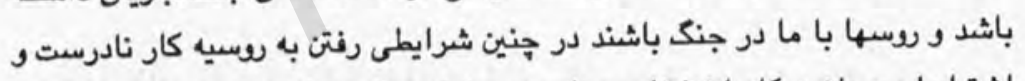

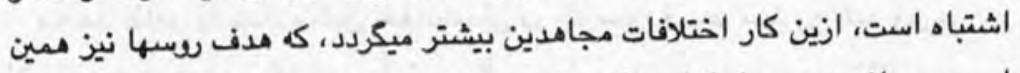

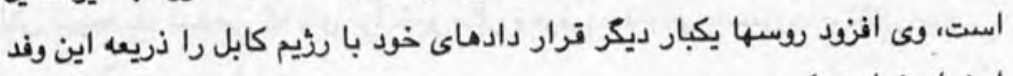

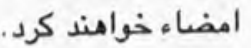

1 نومبر 1991

وفد مجاهدين بتاريخ ·ـ نومبر وارد ماسكو كرديد، بوريس بنكس وذير خارجه

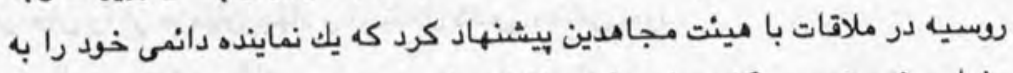

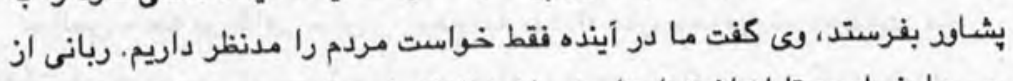

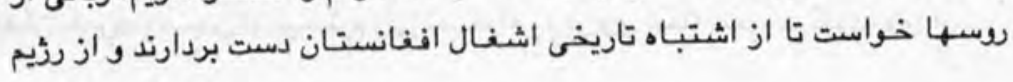


كابل حمايت نكنتد، وىى رمانى اسراى جنكى را يك قضيه انسانى دانست كفت: در

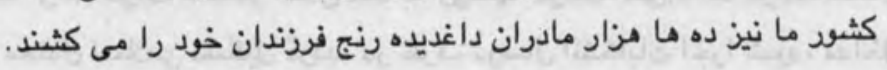

1991 ir

احمد شاه مسعود طى مصاحبه با بى بى سى كفت: فكر نمى كنم جنك بزندى

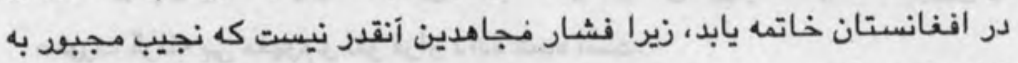

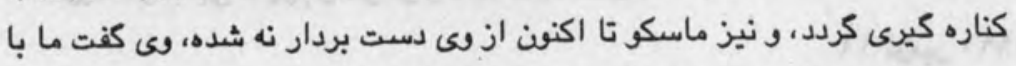

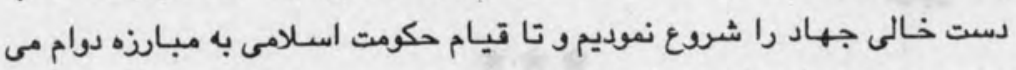
دهيم. و بدين منظود بايد فشار نظامى بر حكومت نجيب بيشتر كردد.

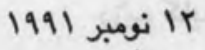

بوريس بنكس رذير خارجه روسيه كفت: ما يكبار درافغانستان مداخلت نموديم

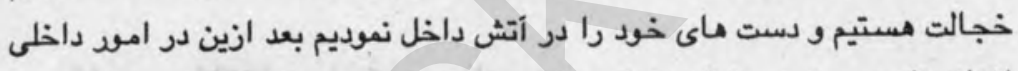

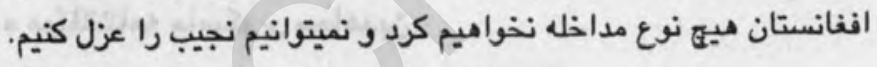
ع أنومبر 1991

$\& \& \&$

وفد مجاهدين از مقامات صسبيه طلب نمؤده تا مبلغ يكمد مليارد دالر غرامات جنك را به افنانها بيردازند.

1991 نومبر 1910

$\& \& \&$

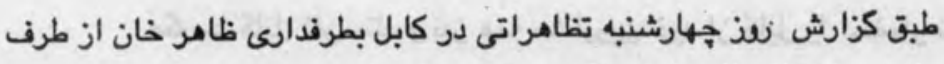

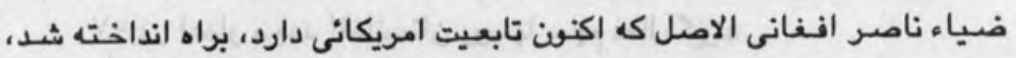

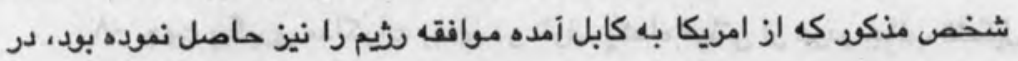

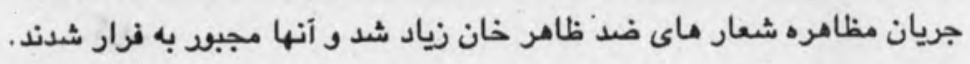
1991 ا نومبر 191 
بعد از مذاكرات ماسكو اعلان شد كه رسبها موافقه نموده اند درافغانستان خكومت معتدل اسلاهى تشكيل كردد، در ظرف دوسال انتخابات اجرا شود، مداخله

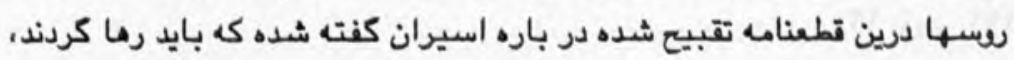

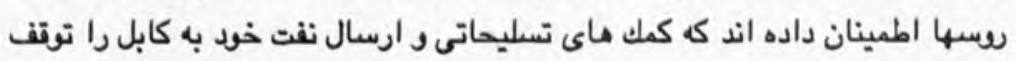

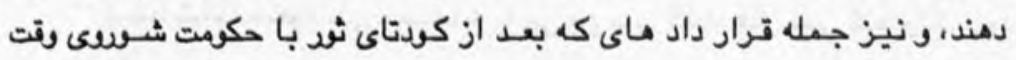

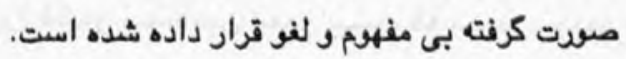
1991 نومبر 17

$\& \& 8$

رذيم كابل از مذاكرات ماسكو استقبال نموده كنته است حكرمت انتقالى صرف طبق طرح مزسسه ملل تشكيل شده ميتواند.

1991 iV

$\& \&$

\section{لشرده موافتتنامه ماسكور مجامدين:}

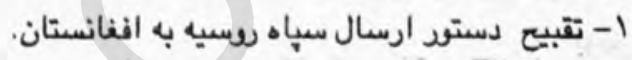

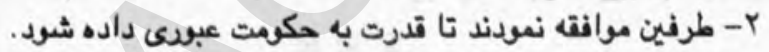

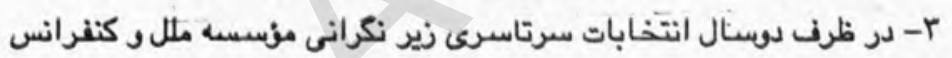

$$
\text { اسلامى صودت كيرد. }
$$

ع- رد و يا تبـول ترار داد هاى كابل ماسكو از سـال I9V^ تا انتقال قدرت

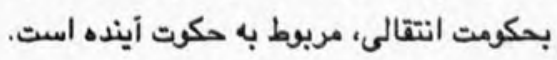

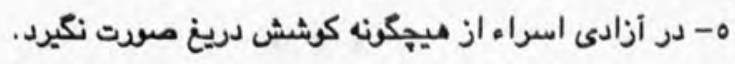

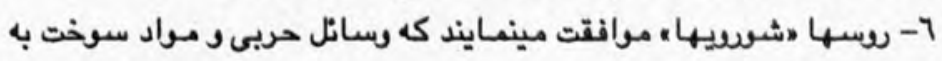
حكرمت كابل نفرستند ر نيز همه مشاودين خود از كابل را احضار نمايند.

$$
\text { - لدر اعمار مجدد افغانستان سسبها سهم فعال كيرند. }
$$

1- جهت بيكيرى مذاكرات بعدى در ظرف يكماه هيتتى از مردو جانب تشكيل

$$
\text { كردد. }
$$

1991 iV 
سياف طى مصاحبه اي مذاكره با رسسها را رد نمودو تطعنامه مادر شده آن

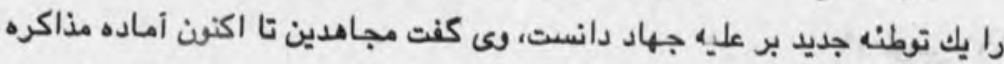

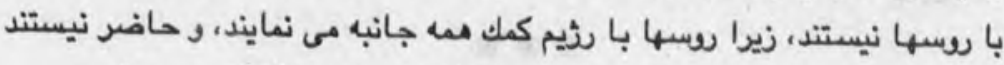

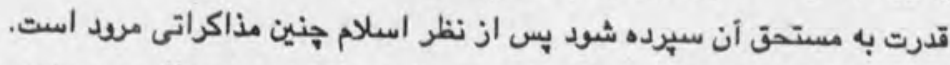

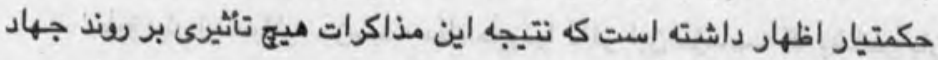

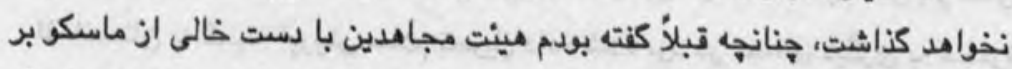

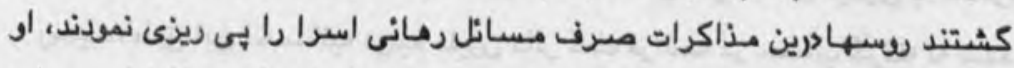

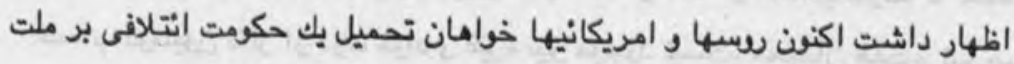

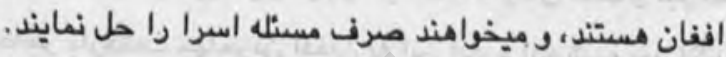

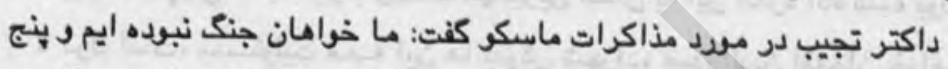

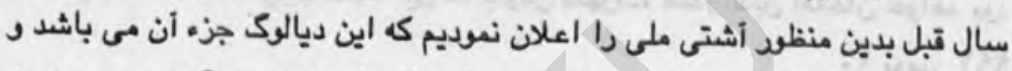

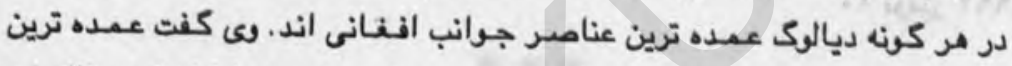

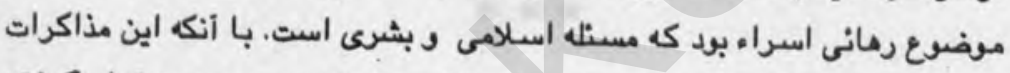

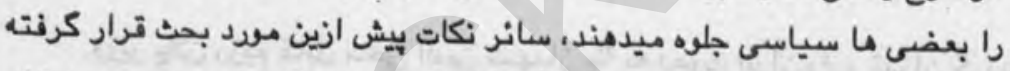

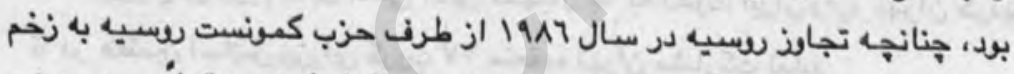

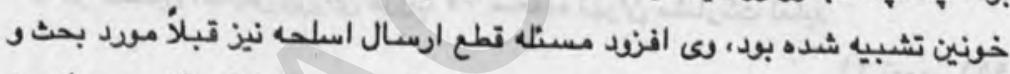

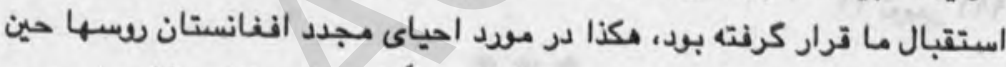

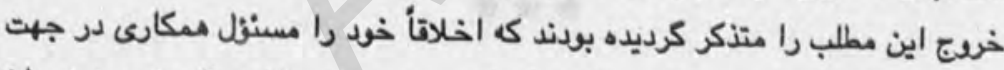

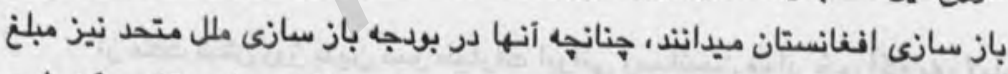

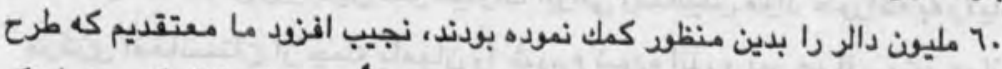

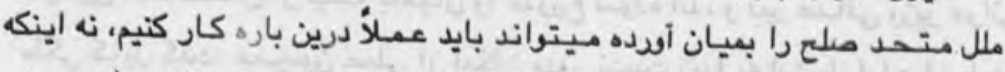

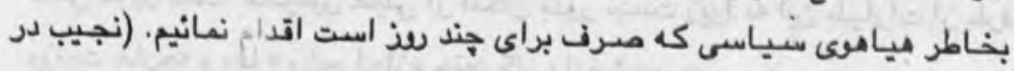
عرض كلم رسسيه-شسوى بكار مييرد ). 1991 11 نومبر

هينت مجاهدين بعد از هنج سذ مذاكره با مقامات سسى به سعودى رفتند و از 
19 نومبر 1991

$\approx \approx$

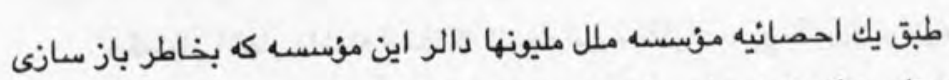

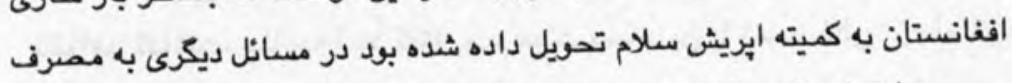

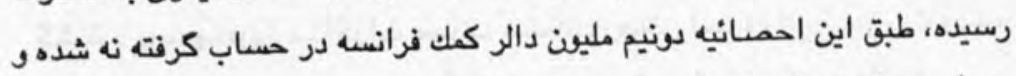

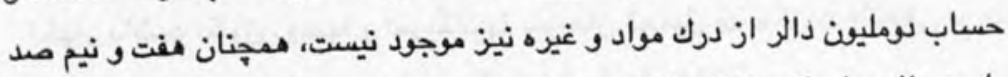

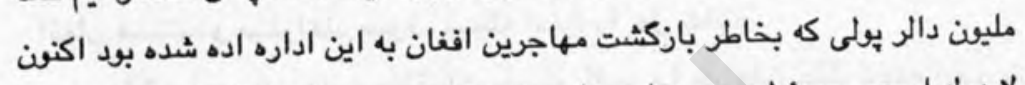

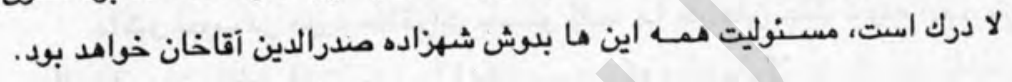

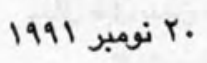

$8 \%$

تذير يلان دثيم كابل محى الدين شهباز بنا به دعوت ايران وارد تهران كرديد تا در هفتمين اجلاس منداى كربي VV منعقده تهران مشاركت نمايد. |r نومبر 1991

$\notin \approx$

از مدت شش ربذ بدين سو طيارات ايرانى رسانيدن مواد خوراكه به ولايات

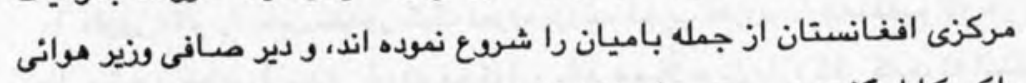

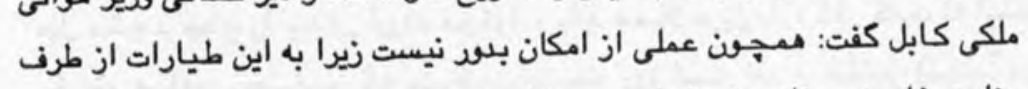

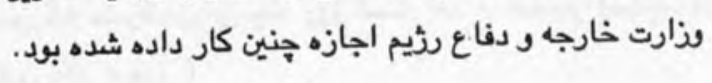

1991 r نومبر

حكمتيار طى يل كنفرانس مطبوعاتى كفت: حاضر نيست اسراى روسى را رها

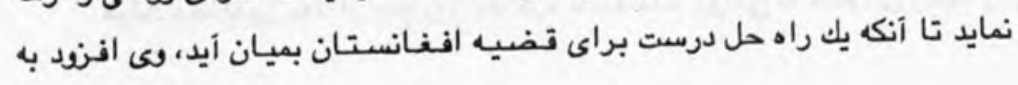




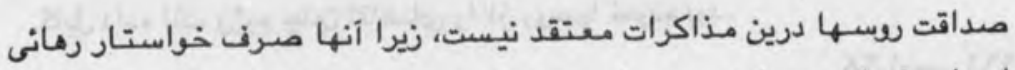

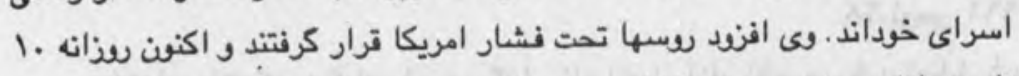
تا ـ م طياره مواد حربى به كابل مي فرستئ.

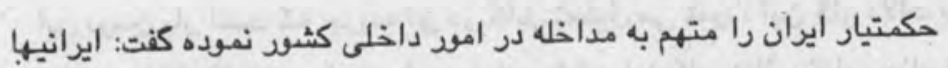

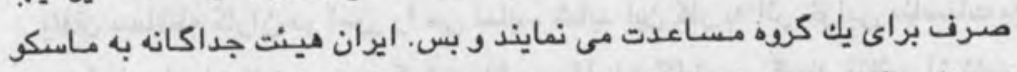

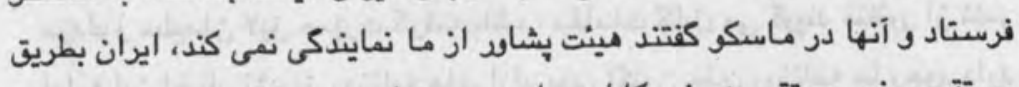

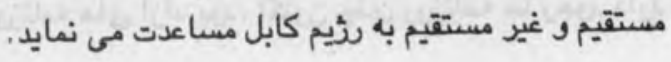
1991 نو نومبر

$\& \&$

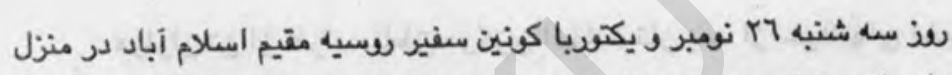

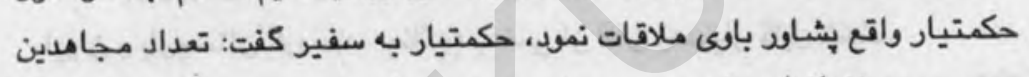

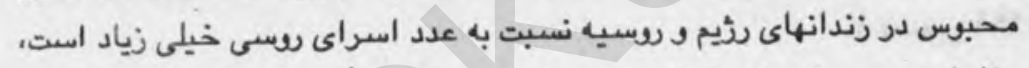

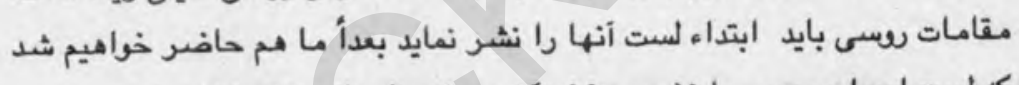

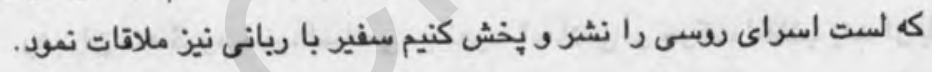

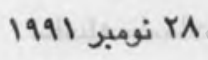

$\& \&$

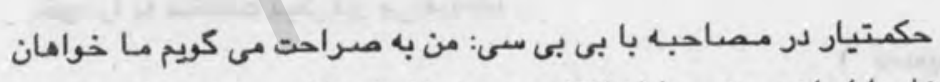

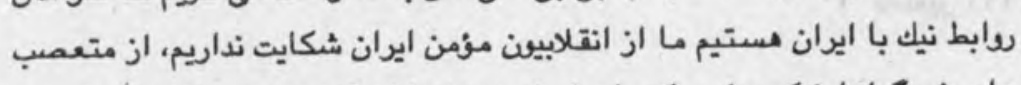

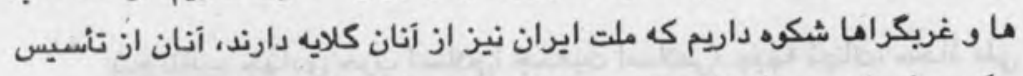

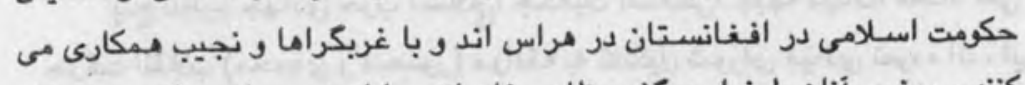

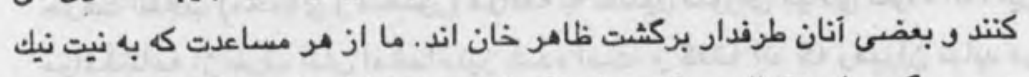

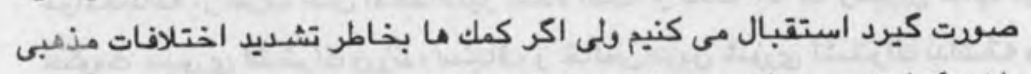

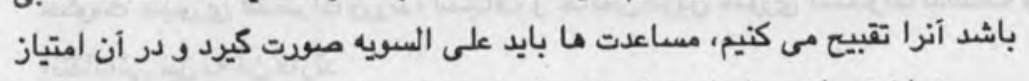

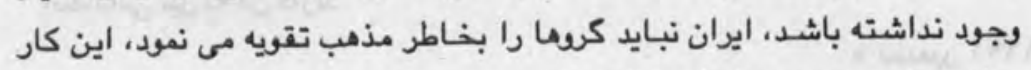

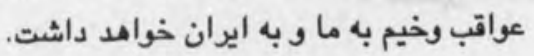

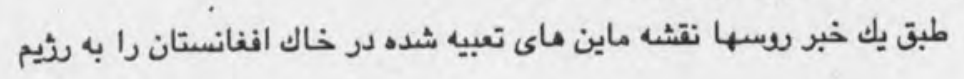


كابل داده اند، رثيم هنين تقاضاى را از سسها نموه بود.

1991 نو نومبر

اخبار هفته كه به كمك شئم در كابل بنام اخبار آزاد نشر مى شد تعطيل شد.

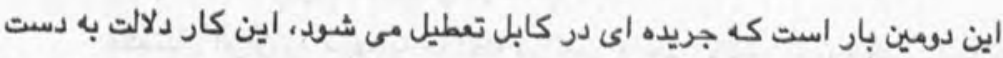

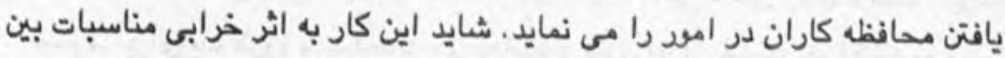

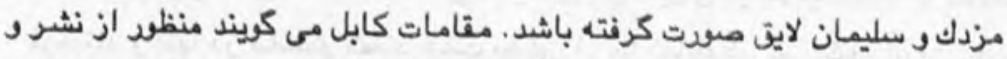

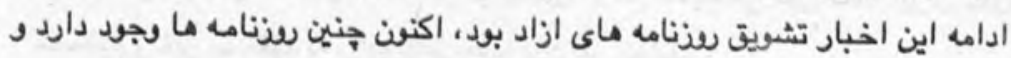
دوام اخبار هفته فايده ندارد.

1991 r نومبر.

هزاران تن از افراد مناطق مركزى افغانستان بعد از سيلابناى اخير سانه

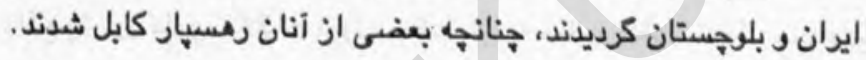
1991 دسمبر 191

رهبران سه كروه حزب اسلامى، جمعيت اسلامى وحركت انقلاب بعد از يك

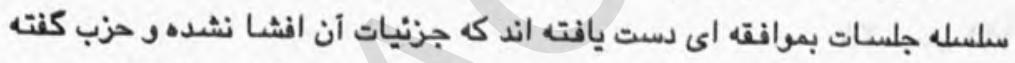

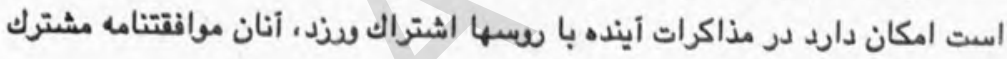

1991 دسمبر 19

خود را به منظمات ديكر نيز مى فرستند.

ينج تنظيم جهادى حزب اسلامى، جمعيت اسلامى، جبه نجات، محاذ ملى و حركت انقلاب (محمدى و منمصر) موافقه به تشكيل شوراى تيادى نموده اند، اين

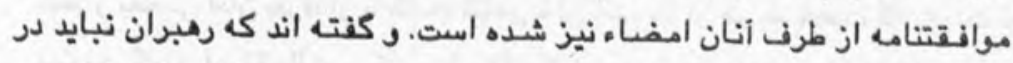

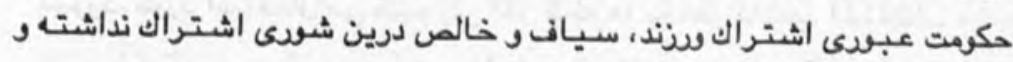

O 1991 دمعبر انتقاداتى نيز به آن دارند . 
عبدالرحمن بثاك در مردد موافتتنامه مجامدين و روسها كفت: بايد در مودد

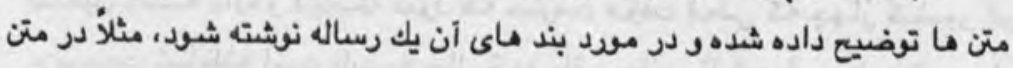

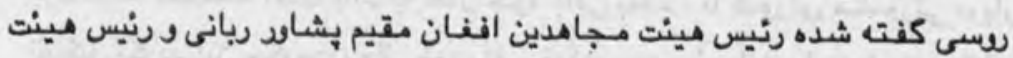

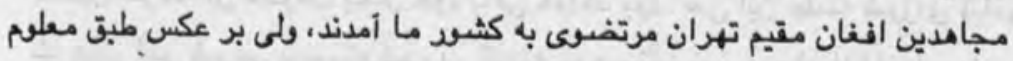

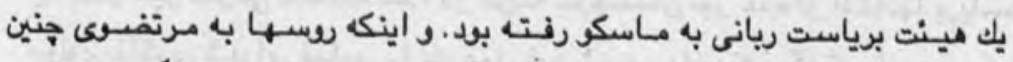

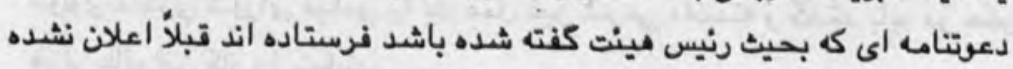

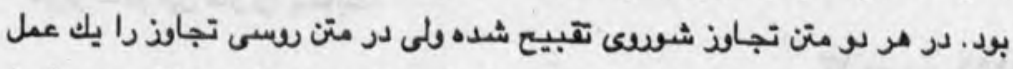

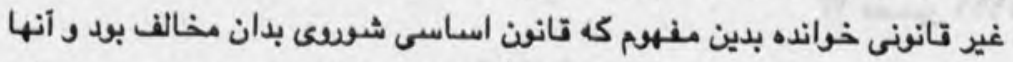

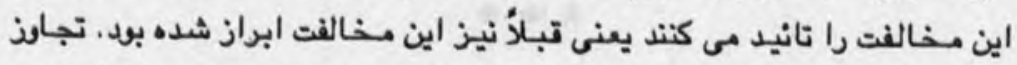

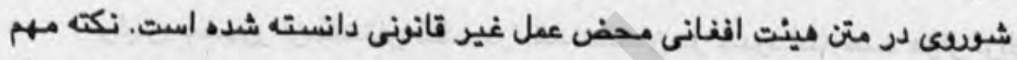

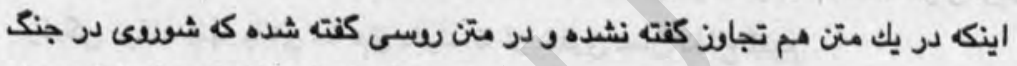

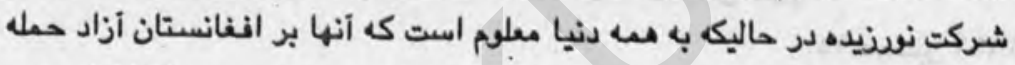

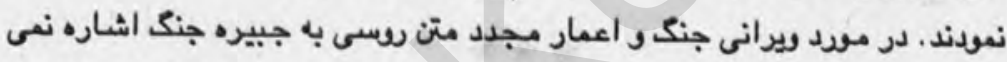

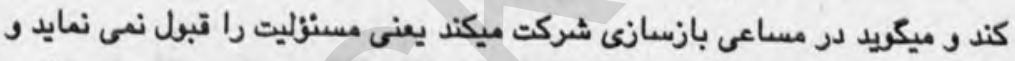

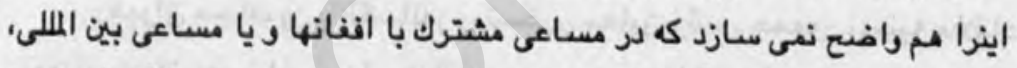

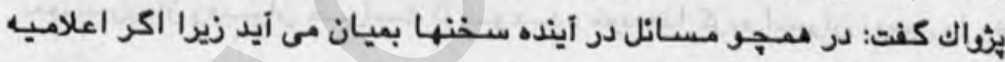

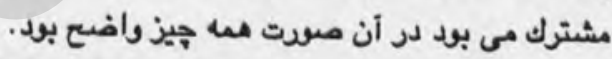

1991 مسمبر

$\& \&$

ماموين افغان كه در ملال احمر سعودى كار ميكند دست به اعتماب زده إنها

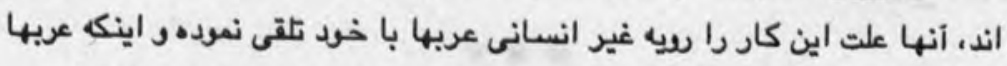

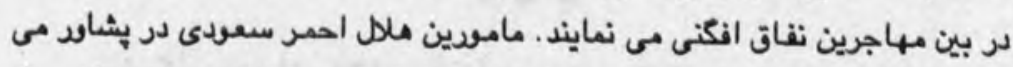

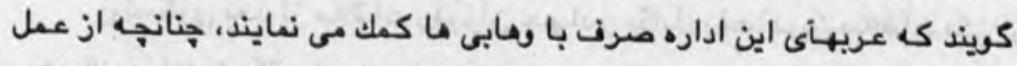

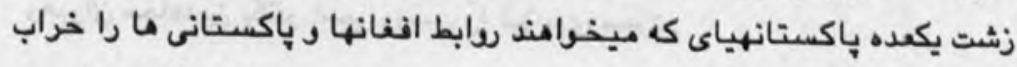

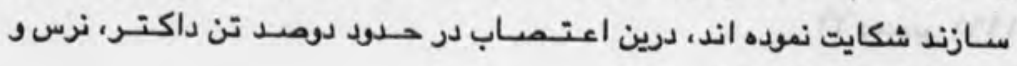

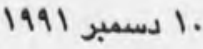
واكسيناتو اشتراك دارند. 
بس از يك هفته از سيرى شدن شوراى قيادى، شوراى اجرائيه جبه نجات

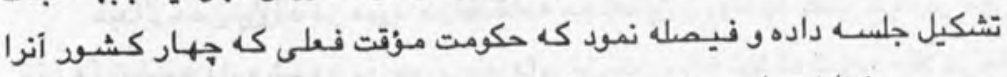

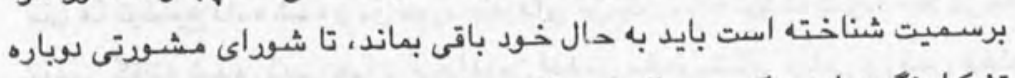

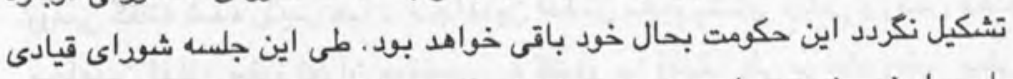

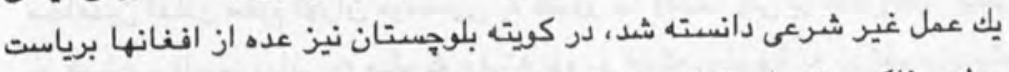

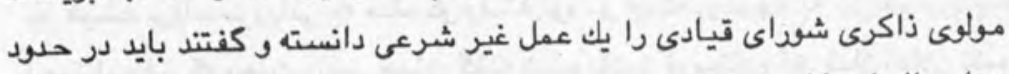

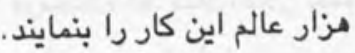

1991 1r

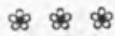

رنيس جمهرد ازبكستان كفت در افغـانستان در حدود سه مـد مزار ازبك زندكى ميكند آنها بالاى ما حق دارند تا از حقوق شان دفان دفاع كنيم.

19 ا دسمبر 1991

\section{$8 \%$}

رهبران مجاهدين بالكساندر رتسكوى معاون رنيس جمهـد روسيه ملاقات

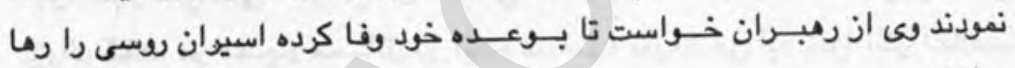
سازند.

حمتيار حاضر نه شد كه تحت قيادت مجددى با هينت روسى ملاقات نمايد.

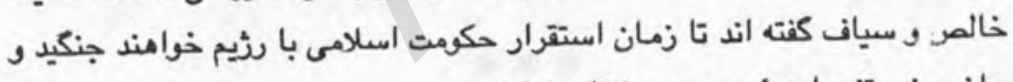
حاضر نيستد با هينت رسى ملاقات نمايند.

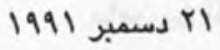

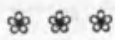

رتسكوى بعد از ملاقات رهبران جـادى بكابل رفت. درين مـاقات يكى از رمبران مجاهدين يكنفر اسير رسسى را نيز برى سبرد.

1991 Rr 


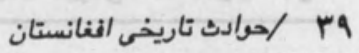

انوسف يكى از كاركنان سفارت رسبيه در كأبل ادعا نموده كه مجامدين

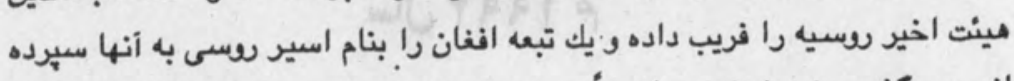

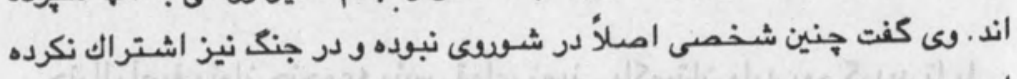
است.

محسنى اين اتهام را رد نموده كفت اين كار غير ممكن است كه ما يك نفر افنان را بنام اسير رسىى به روسها بدهيم. 1991 r 191 


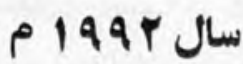

جنرال آصف نواز جنجوعه رنيس قواى زمينى باكستان وارد رم كرديد تا با

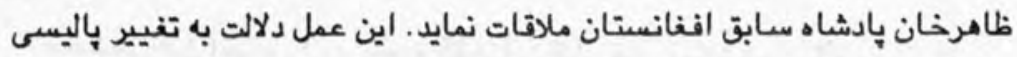
199r حاكستان در قبال مستله افغانستان رامى نمايد. $\notin \%$ حكميار طنى مماحبه از داخل افغانستان كفت: باكستان ميخواهد ظاهر خان

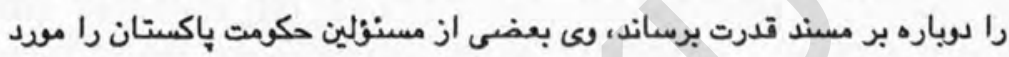

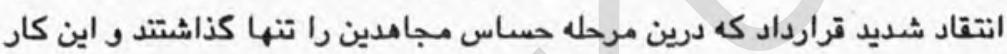
A جنوس

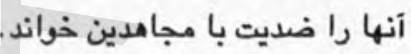
$\& \&$

ويلى برانت رنيس حزب سـوسيال ديموكرات ألمان كه زمـانى صدراعظم آن

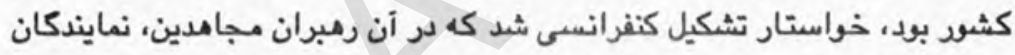

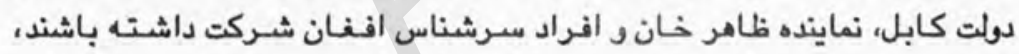

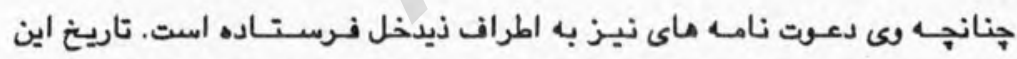
كنفرانس بيست و مفتم جنوى تعيين شده، سه تن از رمبران مجاهدين، بثيم كابل و $199 r_{\text {s.ج. }}$ 'A باكستان از ين طرح استقال نموده اند.

$\notin \%$

عبدالوكيل وذير خارجه و فارق يعقوبى وذير امنيت شثيم در سويس با محمد

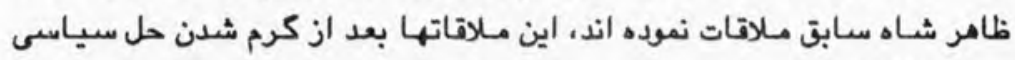

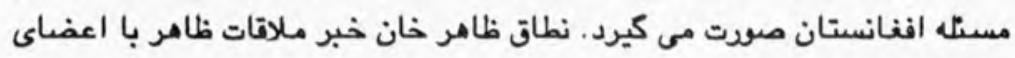
111 رثيم را رد نموده است. 
دولت ايران دو يرواز مـاد غذانى و لباس به كابل فرستاد. اين كار دلالت به

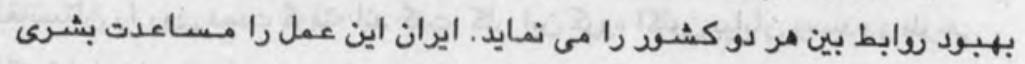
laqr sug ir خوانده است. $\$ \approx$

داكتر نجيب رنيس رثيم طى صسور فرمانى ردذ خرج رسبها' اففانستان را

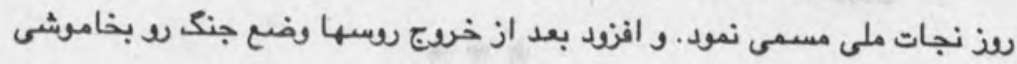
199r 10 نهاده است.

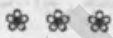

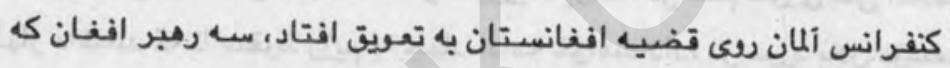

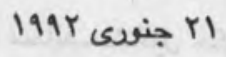

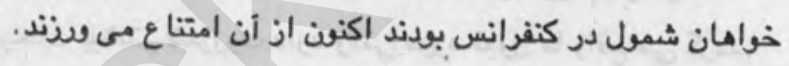
$\$ 8$

مديق كانجو وذير خارجه باكستان طرح مؤسسب ملل مبنى بر داير شدن

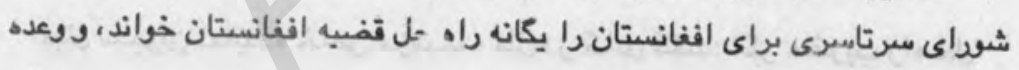
199r Trv داد كه در تطبيق أن همكارى مى نمايد.

مجددى طرح اخير باكستان را استقبال نموده كفت: اكثر افغانها ازين طرح

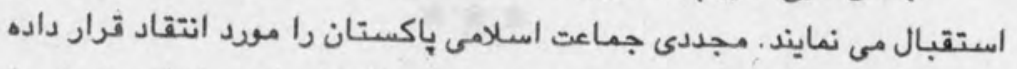
كفت: أنان در امود داخلى ما مداخلت مى نمايند. حكمتيار طى سخنرانى خويش با بال

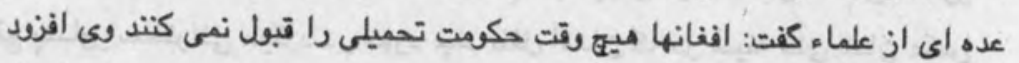

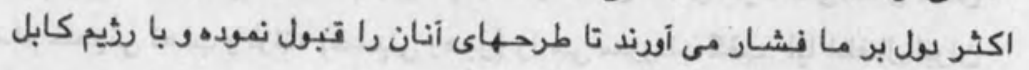
$199 r_{\text {Sug }}$ YA ملاقأت كنيم. 
محمد على جاويد عضو كره جهل و يك نفرى كه طرح جديد براى حل تضيه

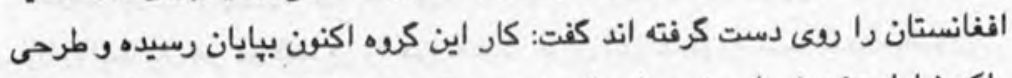

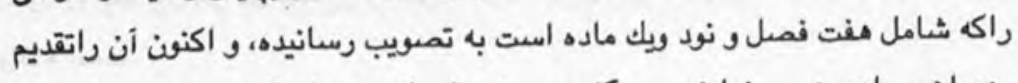

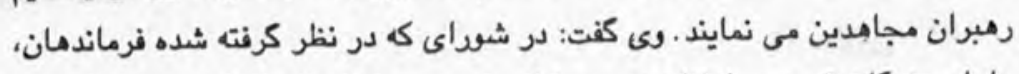

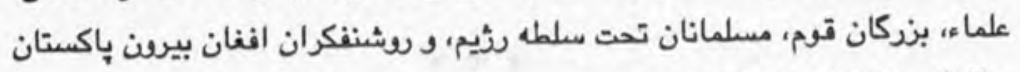

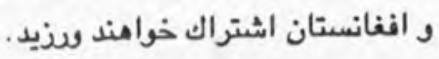

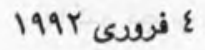

$\$ \%$

شوايى سرتاسرى قوماندانان كه بتاريخ V دلو . IrV در منطقه خوست يكيا

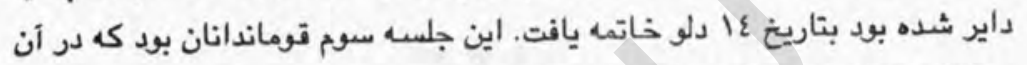

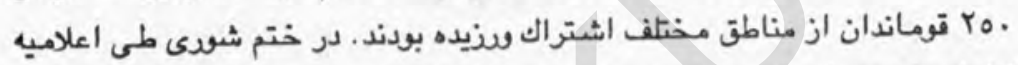

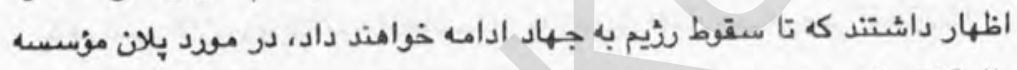

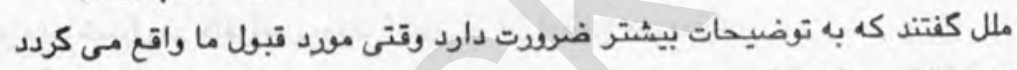

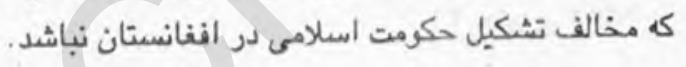

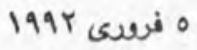

$\$ \& \$$

بينن سيوان نماينده خاص مؤسسه ملل در كابل كفت: اكر عنقريب راه حل

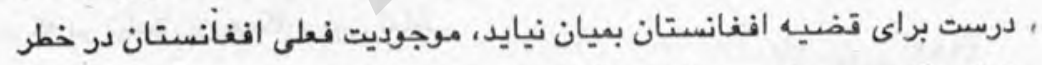

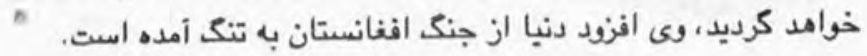

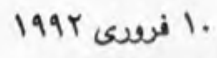

مجددى كه در مراسم تجليل سالكرد انقلاب ايران در خانه فرهنك آن كشود

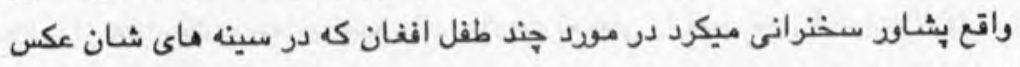

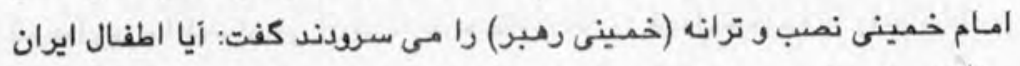

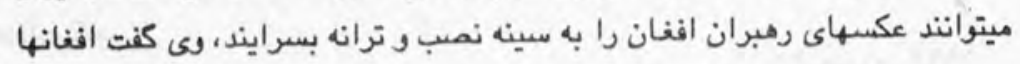


از خود رهبران دارند. ما با ايران و مردم آن علاقه داريم ولى ايرانى ايرانى است و

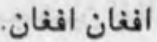

1994 ises 11

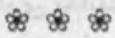

ربانى طى يك كنفرانس مطبوعاتى سه تن از اسيـران سرسى را به هينت آن كشور كه نماينده دولت ازبكستان نيز در آن مجلس حضـور داشت به أنها تحويل داد. اسراء همه ازبك بودند يكنفر أنها حاضر به بركشت و دو نفر ديكر حاضر به

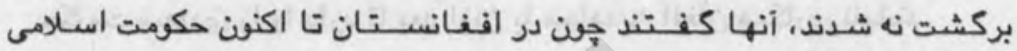
199r ir is تشكيل نه شده بناء ما نمى سويم و جهاد مئ كنيم.

$\$ \$$

اولين اجلاس تشكيل انجمن فرهنكى سه كشو ايران، تاجكستان و مجاهدين

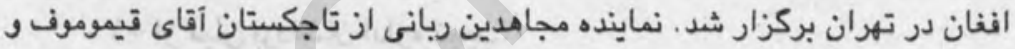

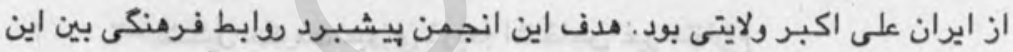
1994 ف ف T. كشور ها كفته شده است.

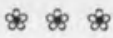

بعد از سـال .191 براى اولين بار مردم كابل بخاطر خروج سوسـيا دست به

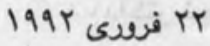

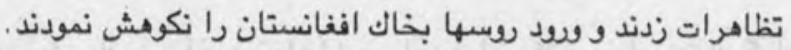

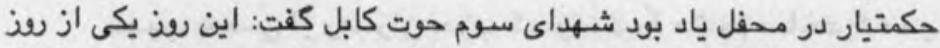

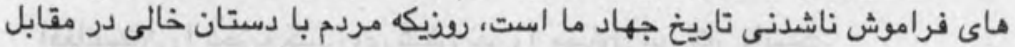

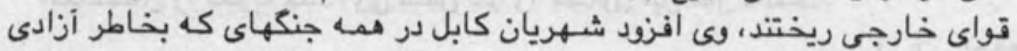

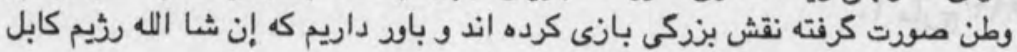

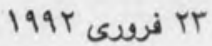

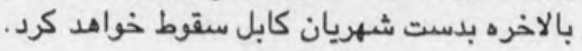


يك هيـت يوكـراينى كـ اكنون در ايران است إز رنيس جـمـهـو آن كشـور رفسنجانى خواهش نموده كه در رهانى اسراى آن كشور كه در نزد مجاهدين افران افنان

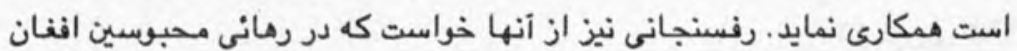
كه در زندانهاى رثيم كابل اند همكارى نمايند.

199r فر

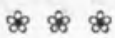

بينن سيوان بعد از ديدار باكستـان وارد سعودى شد، وعى ميخواهد مردم و حكومت سعودى را وا دارد تا بعد ازين با مجاهدين افغان همكارى نتمايند.

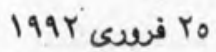

$\mathscr{8}$

حكمتيار بخاطر حل معضله افغانستان طرح حهار فقره اى را ارايه نمود كه

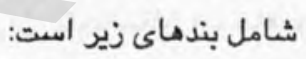
ا- از ميان برداشتن اداره نجيب. r- تشكيل حكومت عبورى ذريعه اشخاص غير بردير متنازع. r- r r r r ع- بركزارى انتخابات و تشكيل حكرمت منتخب اسلامى. ا مارع 199r

داكتر نجيب طى يك ممساحبه خواهان مساعدت امريكا در برابر بنياد كراها

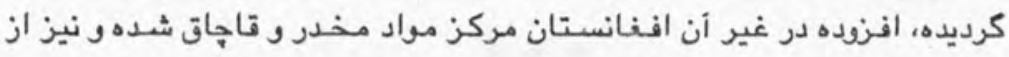

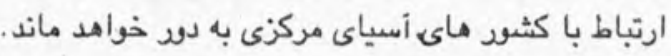

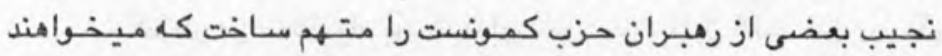
افنانستان را تجزيه كنتد، وعى شش نفر را مسنول اين كار دانست. 199Y 199 
أنعده از خلقى هاى كه با شهنواز تنى به باكستان فرار نموده بودند، مقامـات

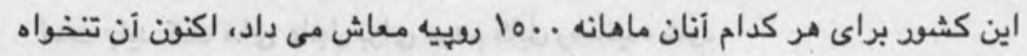

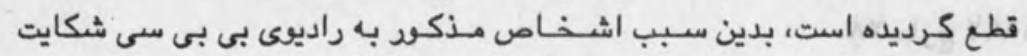

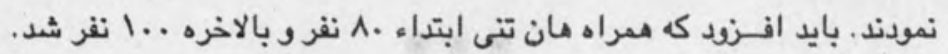

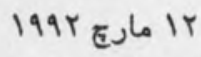

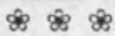

داكترتجيب رنيس رئم كابل اعلان نمود كه در صودت تشكيل حكومت موقت از طرف مؤسسه ملل حاضر است از مقام خويش مستعفى كرديده و ادعاى منمب را نكتد، وى از كروماى جهادى نيز هنين تقاضا را نمود.

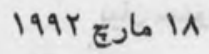

\section{$\$ \& 8$}

شهر مزارشريف كه يكى از بزركترين مراكز دولت بود بدست مجاهدين افتاد، قابل ياد أودى است كه مليشه هاى شمال نيز با نجيب سر مخالفت را كناشته اند، كه اين كار در سقوط أن شهر به مجاهدين كمك كرد. حكومت باكستان و حكومت امريكا از بيانيه اخير نجيب مبنى بر سبردن قدرت بحكومت بى طرف استقبال نموده أن را كامى مثبت در راه ملح خواندند. 199r ש 199

$8 \&$

بينن سيوان بطود غير مترقبه اسلام آباد را بقصد كابل ترك نمود، وى با نجيب و وكيل ملاقات نموده است. 199Y ع مار 


\section{حوادث تاريخى افغانستان/ وع}

رذيم كابل طى اعلاميه كفته است كه مواد ارتزاقى و ذخاير كابل رد بخلاصى است بايد كمك هاى عاجل برايى مردم كابل رسانيده شود.

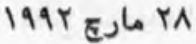

حكومت ايران از همه اطراف قضيه افغانستان خواست تا از طرح مؤسسـ

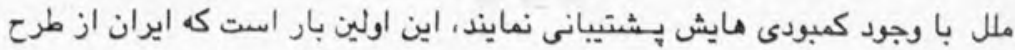
ملل بصورت علنى طرفدارى مى نمايد.

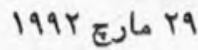

بينن سيوان نماينده خاص سر منشى ملل متحد بعد از مذاكرات خود با على

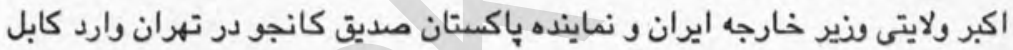

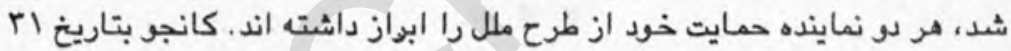
مارع بـ تهران رفته بود، دولت متبوعش خواهان ارسال مواد غذانى به كابل است.

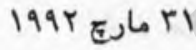

امريز ع ايريل دوطياره PIT باكستانى مملوه از مواد ارتزاقى وارد كابل شد، اين اولين همكارى علنى بولت باكستان طى حند سال اخير به حكومت كابل است. حكومت باكستان وعده داده كه به مقدار ده هزار تن كندم به كابل مي فرستد، تا از طرف نمايندكان مؤسسه ملل به مردم توزيع شود. ع إيريل

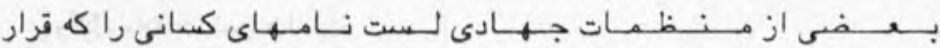

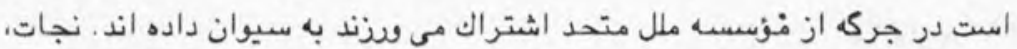

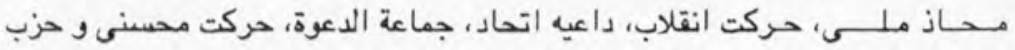


اسلامى لست اشـخاص مورد بسيند خـود را تقديم نماينده ملل نمودند، در حاليكي ع ابريل نطاق حزب اين موضوع را رد نمود مورد

$\notin \&$

حكممت كابل از ارسال كملث باكستان استقبال كرم نموده و آن را اقدام نيك

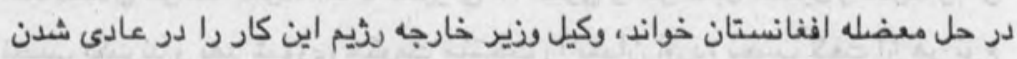

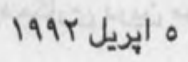
روابط دولتين مفيد خواند.

بطروس غالى ستر منشى مؤسسه ملل از همه مردم دنيا خواسته است تا به

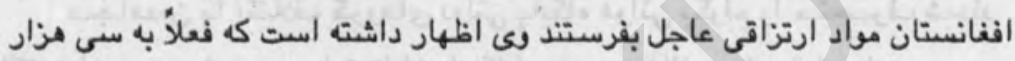

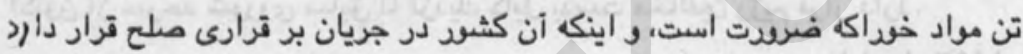

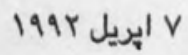

$$
\text { بايد مودد مساعدت قرار كيرد. }
$$

\section{\& क}

امريكا اعلان نمود كه مقدار ده هزار تن كتدم به كشور جنك زده افغانستان

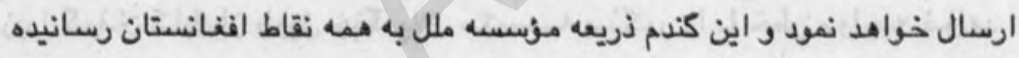
خواهد شد.

\section{9}

سيد منصود نادرى يشتيبانى خود را از تأسيس حكومت جنبش اسلامى ملى ثلى

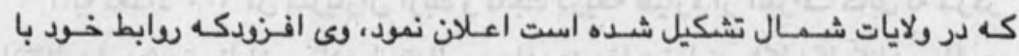
احمدشاه معسود را قطع نموده است. تا اكنون مسعود درين مودد هيزيى نه كفته 9 ابريل 1991 اولين طياره حامل مـاد غذانى از تبيل كندم، رغنن و نخود ايران وارد كابل 
شد، قرار است سلسله اين امداد ها بكابل ادامه يابد.

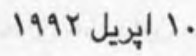

بطروس غالى سر منشى مؤسسه ملل متحد اظهار داشت كه همه اطراف قضيه

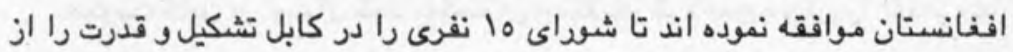

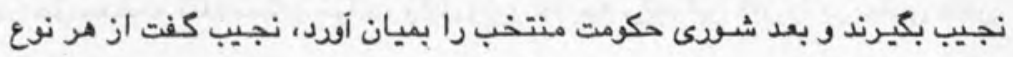
همكارى درين مودد دريغ نمى صزد و حتى حاضر خواهد بود تا كشود را ترك كويد.

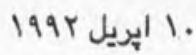

مجاهدين با ايتـلاف كردهاى دولتى يايكاه هوانى بكرام را متمبرف شـدند

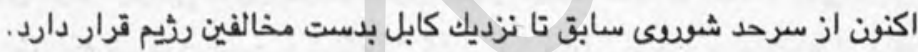

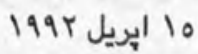

$\& \& \&$

. امريكا، باكستان و ايران جدأ از مجاهدين تقاضـا نموده اند تا رثيم كابل را

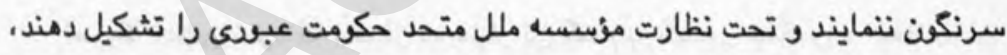

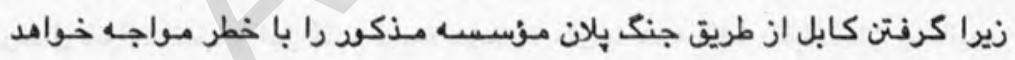

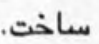

1799

$8 \& 8$

به تعداد . .7 تن سربازان ازبك و تاجل ذريعه طياره از اطراف كابل به مركز

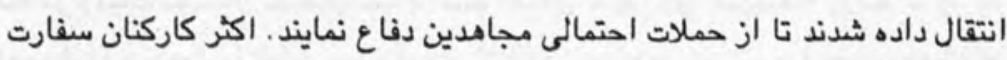
روسيه كابل را ترك نمودند.

17 ابريل1999 


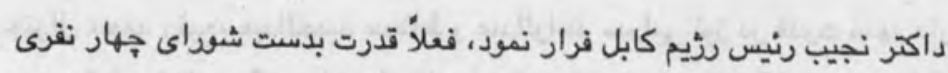

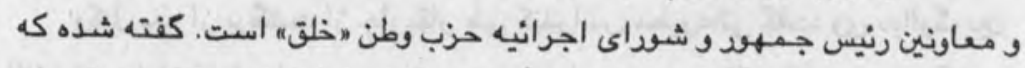

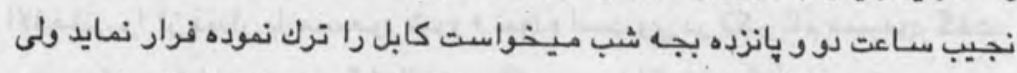

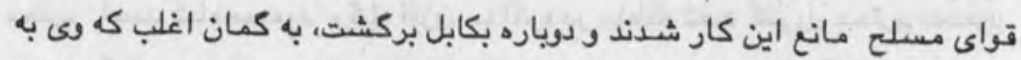

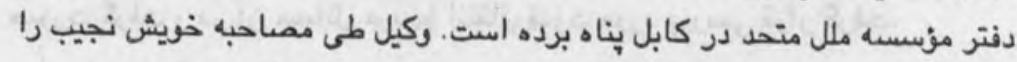

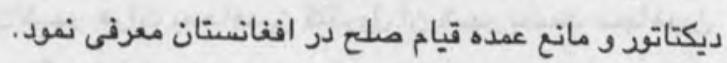

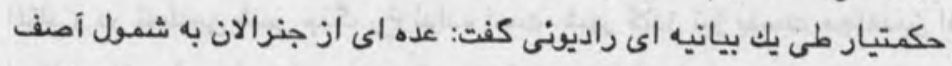

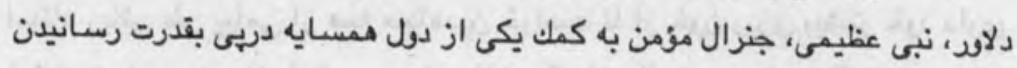

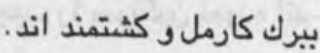

1997 ايريل 17

\section{\& क \&}

قوماندانى كارنيزيون كابل طى اعلاميه اي بـ شهريان كابل اطلاع داد كه نظم

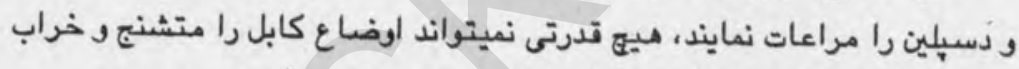
$199 r$ إيريل 19

$$
\text { سازد . مجاهدين اكنف در كرد و نواح كابل كرد آمده اند. }
$$

888

مؤسـسه ملل متحـد با تدوير جلسـ اضطرارى خـويش از مجـاهدين افنغان

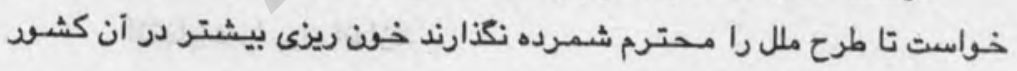

عبدالوكيل ونيرخارجه رثيم كابل را بقصد هاريكار ترك كفت وى ميخواهد با صودت كيرد.

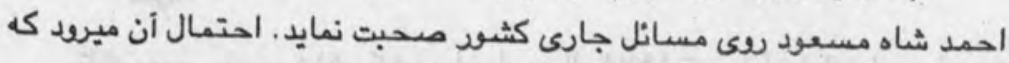
ايريل I99 IV فريد مزدك رياست حزب وطن را بدوش كيرد.

تدرت كابل فعلأ بدست جنرال نبى عظيمى، جنرال مزمن، جنرال أصف دلاور

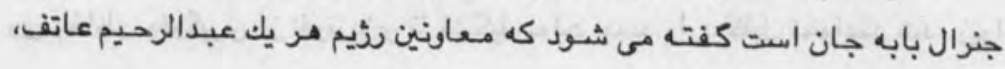


جنرال محمد رفيع، عبدالحميد محتاطو عبدالواحد سرابى نيز در قدرت سهم دارند.

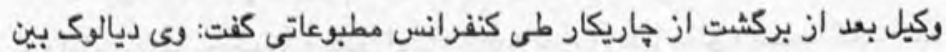

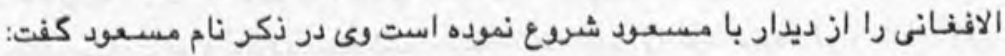

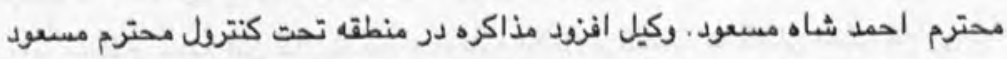

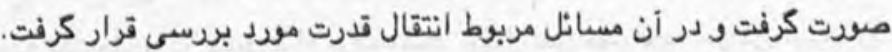

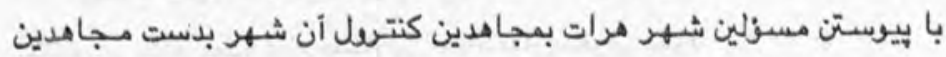
افتاد و در تسليمى شهر جنك رخ نداده است. شهر كندز نيز بدست مجاهدين افتاد.

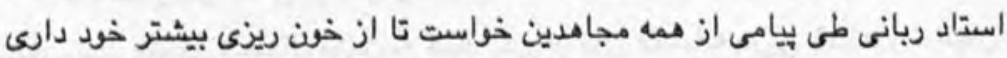

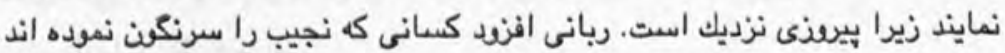

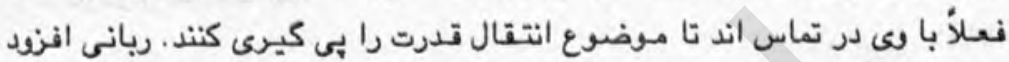
رقتى مجاهدين منطقه به مشكلى مواجه شدند با مسعود تماس بر قرار نمايند. 11 ايريل نوايند 199

حزب اسلاهى بخاطر بيرن شدن از وضص كنونى هنين ييش نهاد نمود:

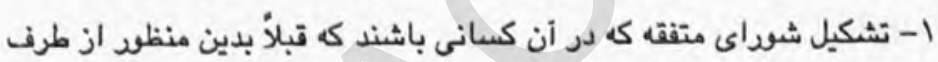
منظمات جهادى معرفى شده اند. r- تشكيل حكومت موقت از طرف توماندانان اطراف كابل تا زمينه بركزارى انتخابات را براه اندازند. r- و يا سهريبه متنانب براى منظمات جهادى جهت تشكيل حكومت داده. شود .

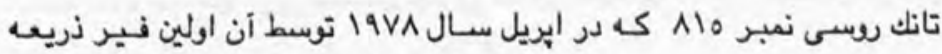
اسلم وطنجار بر ارك صودت كرفت و تا اكنون در برابر ارك قرار داشت، امروذ از طــرف مق ــامات كابل از أنجا بر داشته ور در جايش كل كذاشته شد. احمد شاه مسعود طى مماحبه مطبوعاتى در شهر هاريكار كفت: نيروهاى وى بخاطر جلوكيرى از خونريزى تا تشكيل دولت جديد وارد كابل نخواهند شد، زيرا 
در آن صسرت راه براى كروهاى بى نظم و جيارلكر باز خواهد شد.

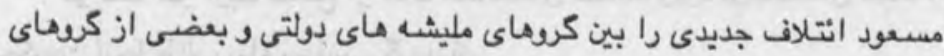

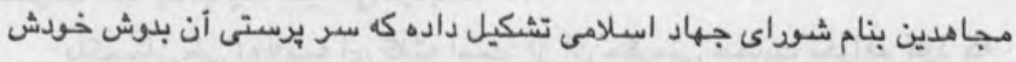

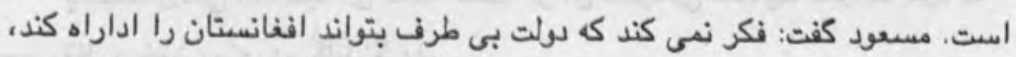

قسمت اعظم سمت شمال كثود بتمرف شوراى مذكود قرار دارد .

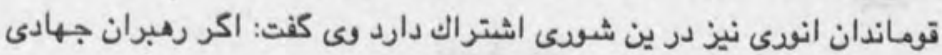

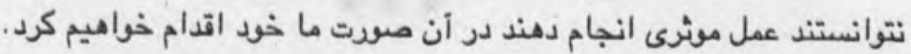

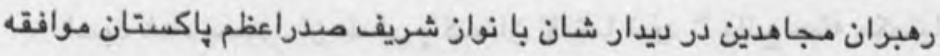

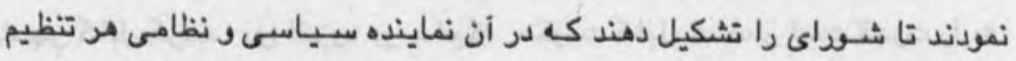

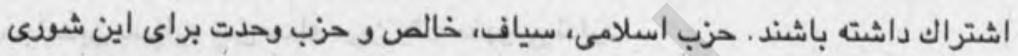

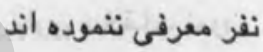
ولايات هلمند، فيض أباد ور ميدان شهر بدست مجاهدين افتاد، كرهاى دولتى 199 19 19 اين مناطق به مجاهدى بيوستند. $\notin \otimes$

حكمتيار طى بيامى كه به اداره فعلى كابل فرستاده كفته است: اكر دولت تا

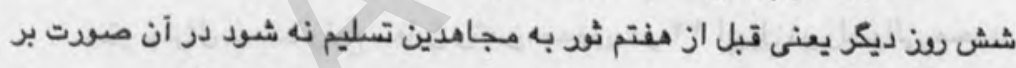
كابل حمله صورت كرفته و طرف مقابل مودد عفو نيز قرار نخواهند كرفت. 199r إيريل

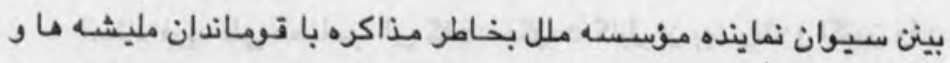
مجاهدين روانه مزار شريف كرديد. عبدالرحيم عاتف طى كنفرانس مطبوعاتى كفت:

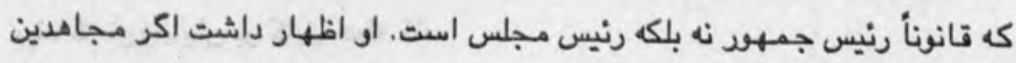

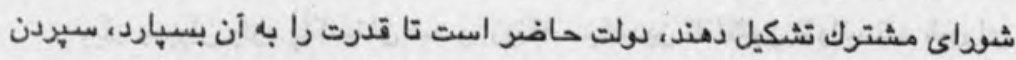
دولت بـ يك كروه خاص غير ممكن است.

$\mid 99 r$ | إيريل 
دو صد نفر ازبك مسلح از خال افغانستان كذشته وارد تركمنستان شدند، و از حكومت أنجا طالب بناه سياسى كرديدند.

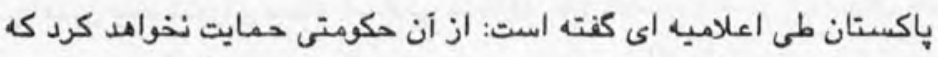
سبب قتل و خنف ريزى در كابل كردد.

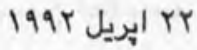

क8 क क

احمد شاه مسعود از علمايى باكستان تقاضا نمود تا مانع حمله حكمتيار بر

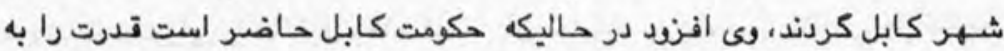
مجاهدين بسيارد خس حمله درين وقت مفهومى ندارده.

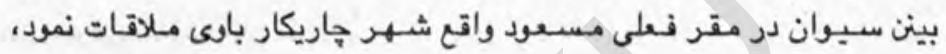

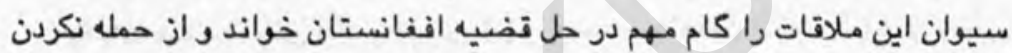

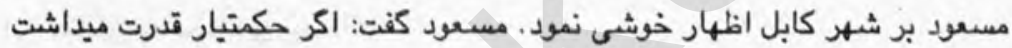
تا اكتون بر كابل هجوم مى أودرد.

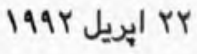

ستر جنرال محمد رفيع معاون رنيس جمهود در بr ايريل در ولسوالى محمد

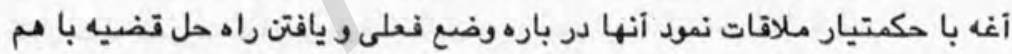
محبت نمودند، اين منطقه تحت كنترول حزب اسلامى قرار دارد .

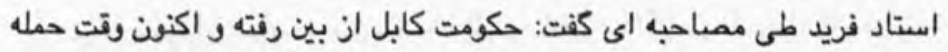

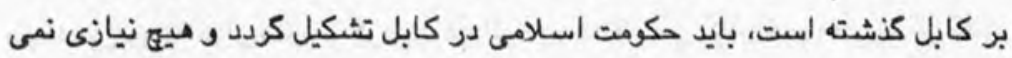
بيند كه نيروهايش بر كابل حمله كند. بينز سيوان وارد باكستان شد و ازينكه مجاهدين تا اكنون نتوانستند شرداى

$$
\text { خود را تشكيل دهند ابراز ناراحتى كرد . }
$$

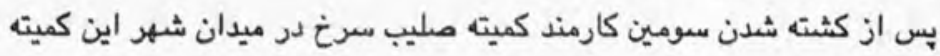
199r Tr

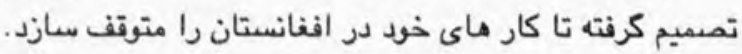


هين مخـالفت خـود با يكجانئى دين و سـياست را ابراز داشـته است. و بدين

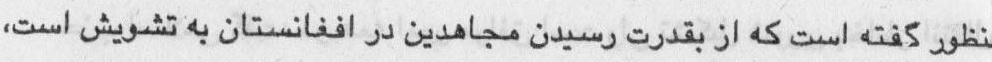

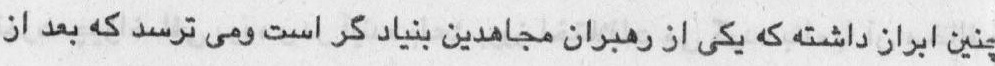

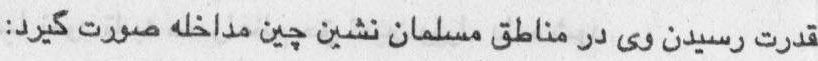

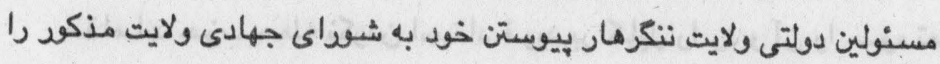

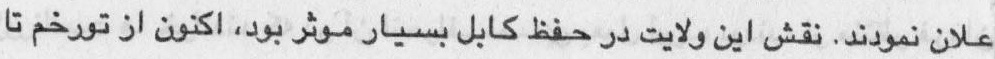
كابل بدست مجاهدين افتاد. ماسكو يك هينت خود را بخاطر مذاكره با مجاهدين به كابل فرستاد تا در باره

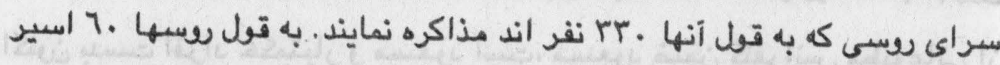
ر راخل افغانستان و بقيه در خارج اند.

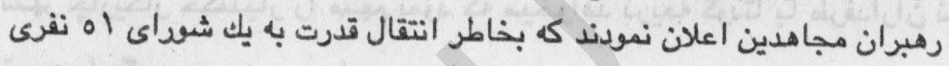

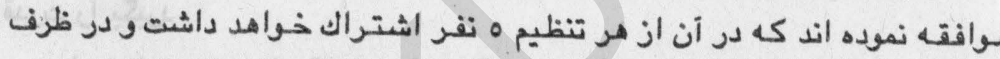

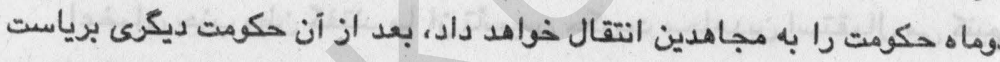

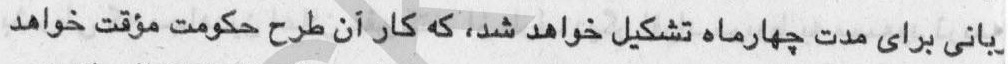

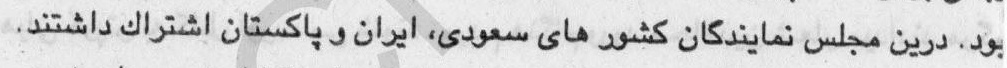

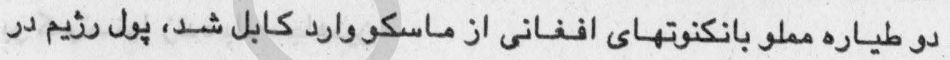

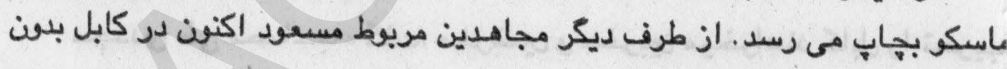

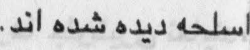

\section{9r ك آبريل}

سياف طى كنفرانس مطبوعاتى در كورنرهاوس بشاود كفت: ده تنظيم جهادى

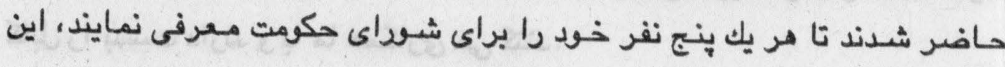

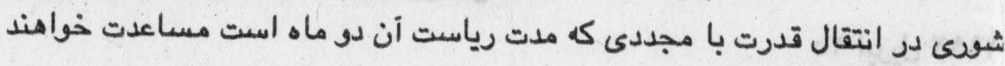

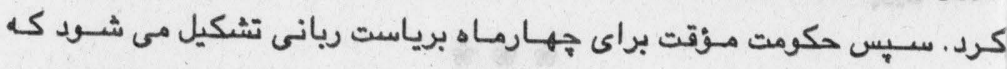

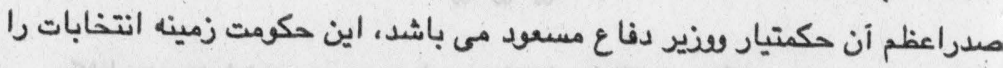

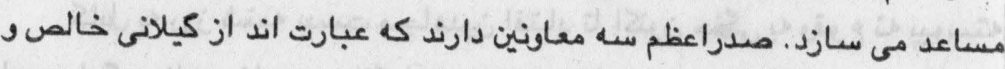
وذير خارجه احمد شاه

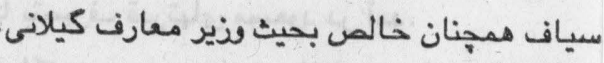
احمدزى بمفت ونير داخله و مولوى نبى بمفت رئيس ستره محكمه تعيين شده اند.

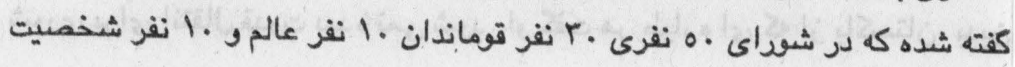




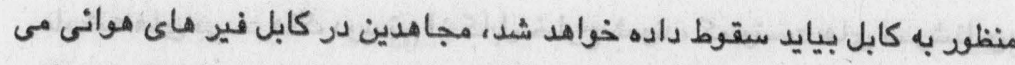

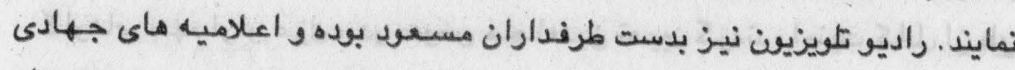

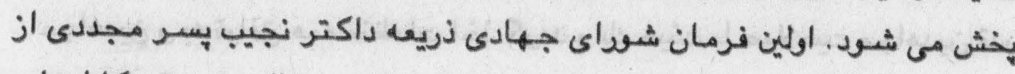

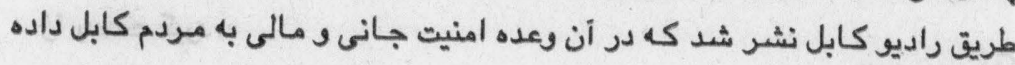

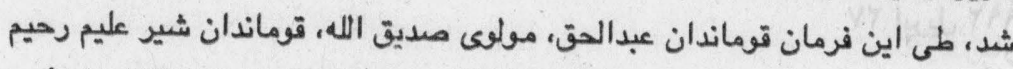

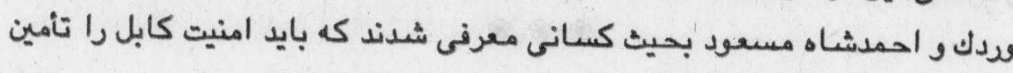
كنتد، و از مسعود تقاضا شده كه زود تر به كار خود آغاز كند.

199r إيريل

جنك شديدى بين نيروهاى مسعود و هكمتيار در شهر كابل در كرفته است،

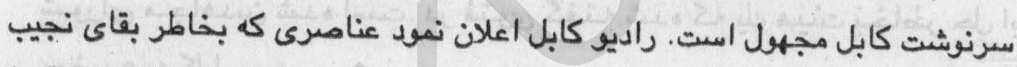

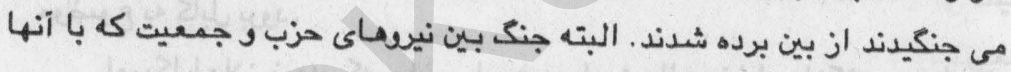

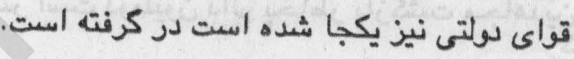

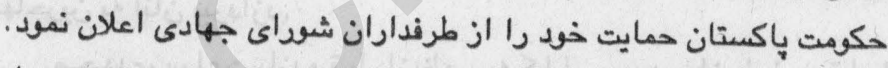

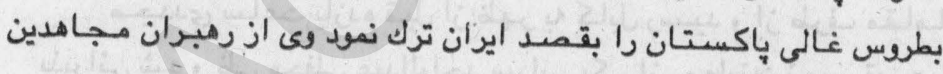
خواست تا جنك در كابل را توقف دهند.

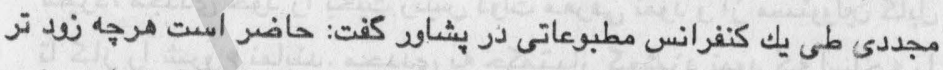

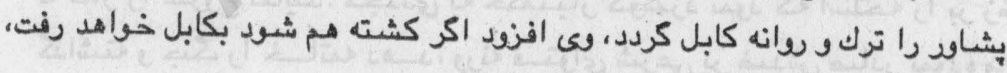
1997 Tr إيريل

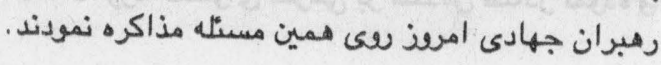

مجددى امرون ذريعه موتر از باكستان مازم كابل شـد، اودر سرهد بين

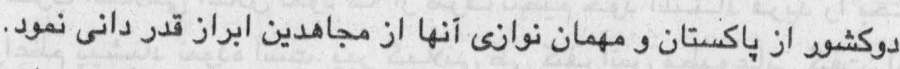

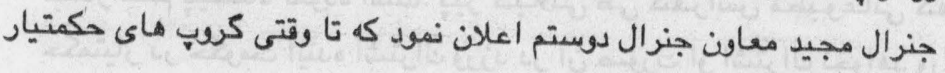

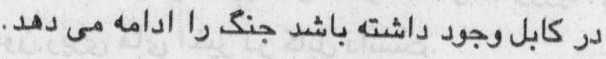

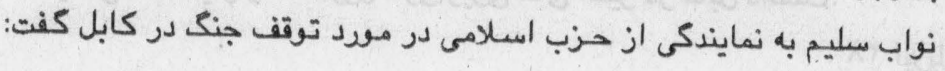


حكومت هند كـ از طرنداران رثيم كابل بود اكنون ابراز خـورسندى نمود ازينكه حكمتيار نتوانست بر كابل قابض كردرد

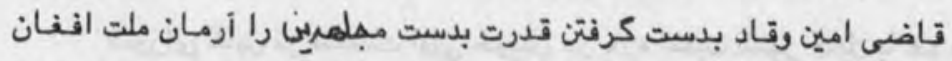

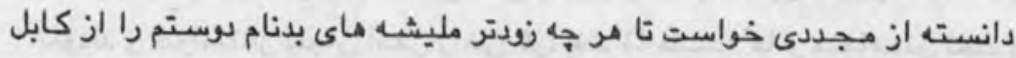

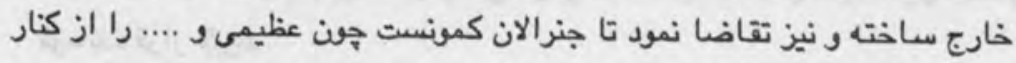

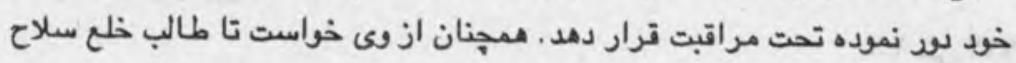

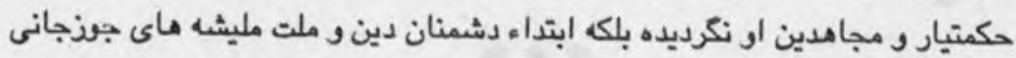

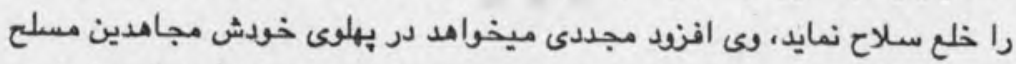
ديده شود ولى ميخواهد مجاهدين حكمتيار را خلع سلاح نمايد، اين يل اشتباه است كه بايد مجددى مرتكب أن نكردد.

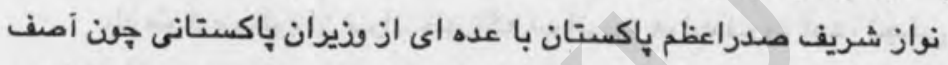

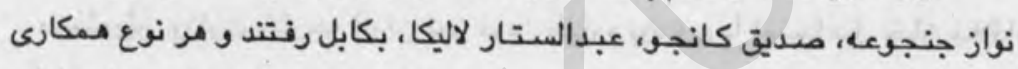

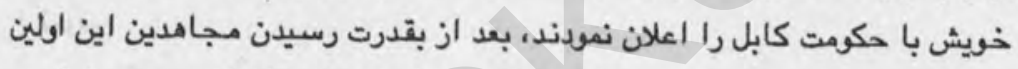

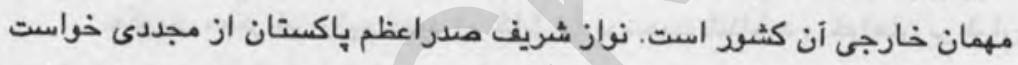

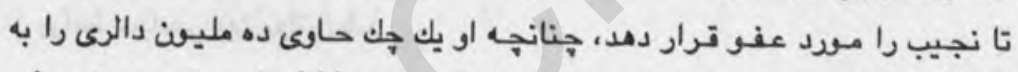

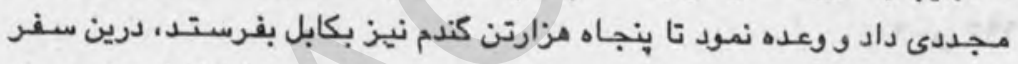

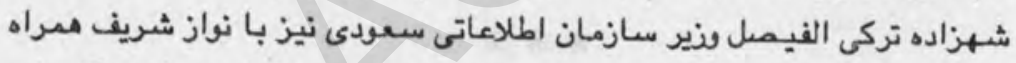

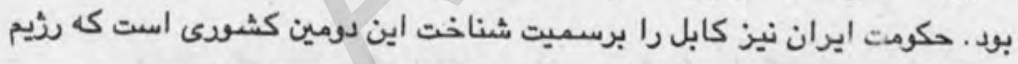

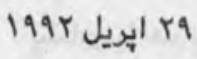
جديد كابل را برسميت مى شناسن.

$\$ \$$

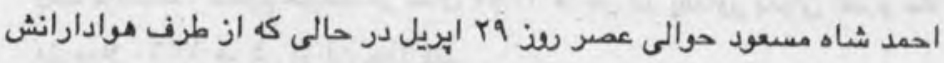
با موترها و تانكها بدرقه مى شد والى وارد كابل شد .

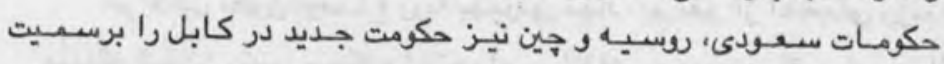

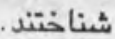
بير كيلانى كه نامزد وذارت خارجه است محمد صديق سلجوقى را بحيث سفير

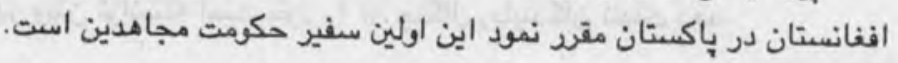

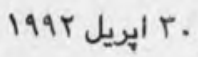




\section{هوادث تاريخى افنانستان/ مه}

هند نيز رثيم جديد در كابل را برسميت شناخت و خواهان روابط دوستانه با

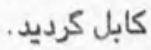

شواى كابل در نشست اولى خويش در باره امنيت شـهر كابل با هم مذاكره

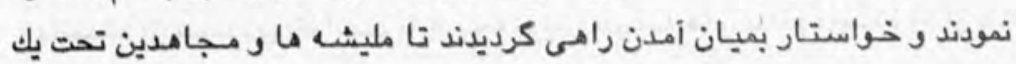
قومانده قرار كيرند.

ا مى 199r

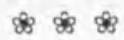

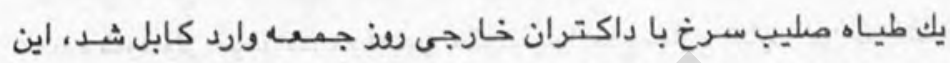

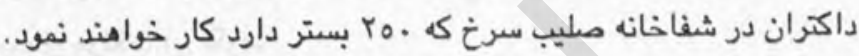

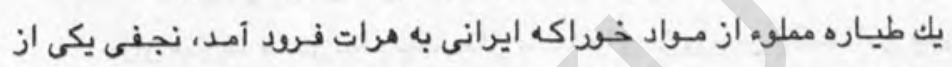

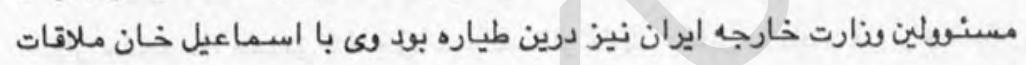
نمود.

حكومت مصر نيز رثيم جديد در كابل را برسميت شناخت و خواهان بر قراسى روابط سياسى بين دولتين شد. 199r R

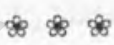

سه تنظيم كه بنام حركت انقلاب اسلامى بودند طلى يك كنفرانس مطبوعاتى در

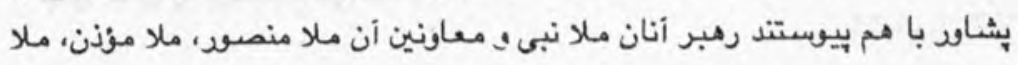

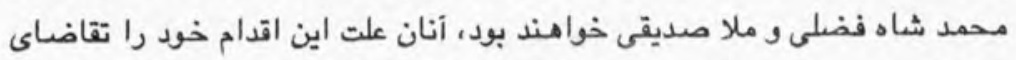

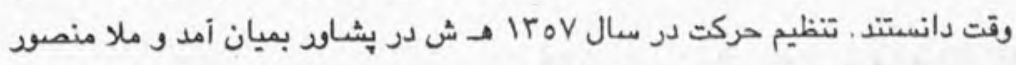

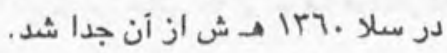

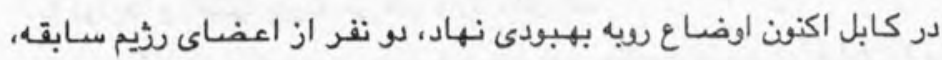

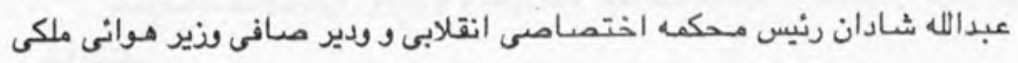

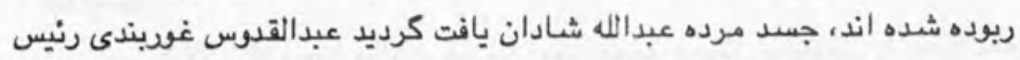

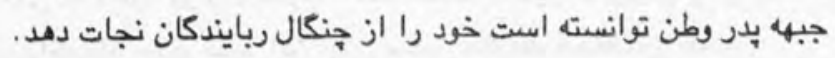
1994 nt 
بينن سيوان نماينده سر منشى مؤسسه ملل بعد از انتقال قدرت به مجاهدين

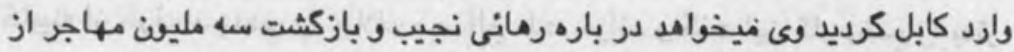
باكستان به افغانستان با مقامات كابل مذاكره ورد نمايد.

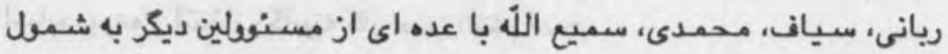

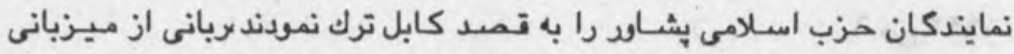

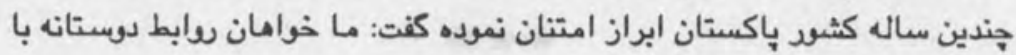
ع مى 1997 باكستان مستيم.

مجددى كه رياست .0 نفرى شوايى انتقال قدرت را به عهده دارد كابينه خود

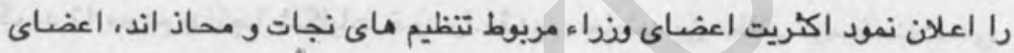

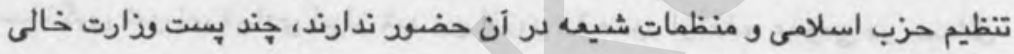
كذاشته شده است.

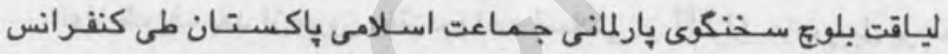

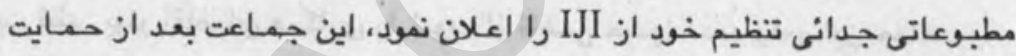

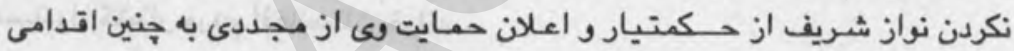
دست زد. مجددى كفته است كه مدت دوماه براى كار كافى نبوده و اين تمسميم بمورت

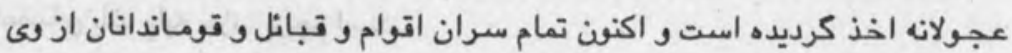
تقاضا مى نمايند كه بايد دو سال درين مقام بماند. 1994 می

\section{$\$ \&$}

عدهء ايى از قوماندانان برياست حقانى با حكمتيار ملاقات نمودند، آنان از رى

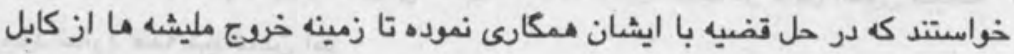

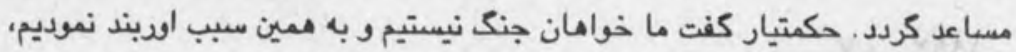

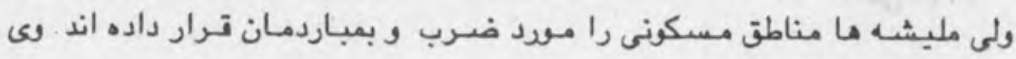


افزود: نميدانم كه مسنول اوربند مجددى است، يا رباني و يا مم دوستم! او اعلان

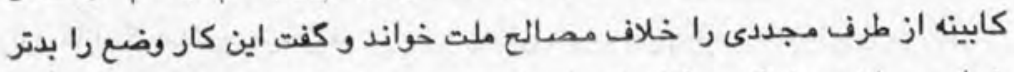

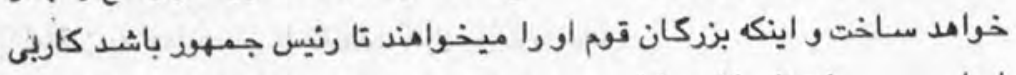

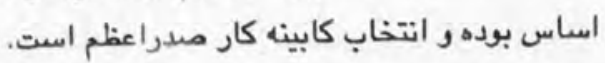

$199 r^{1}{ }^{7}$

بين رهبران مجاهدين موجود در كابل و حكمتيار موافقه صورت كرفت تا جنك

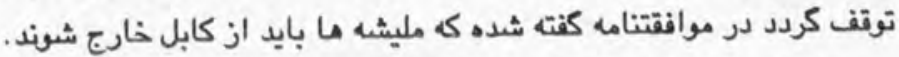

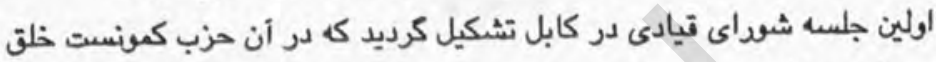

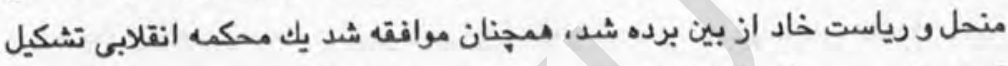

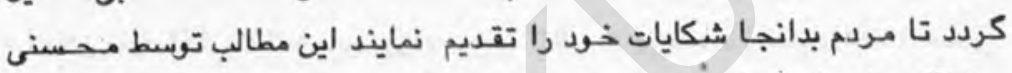

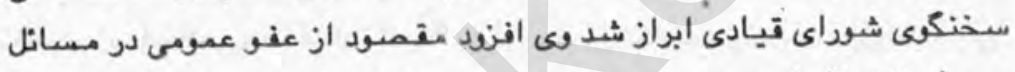

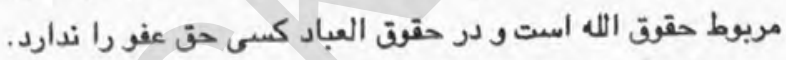

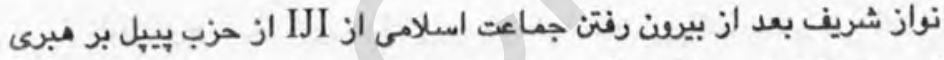

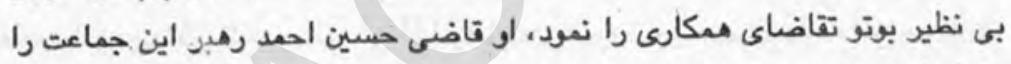
مسنول كثتار مردم افغانستان خواند. راديو كابل اعلان نمود كه جنرال رحيم دردك سهواً بحيث لوقى درستيز تعيين

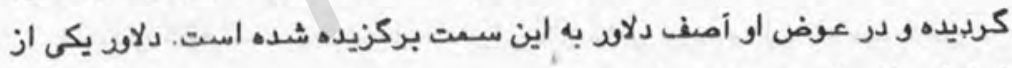

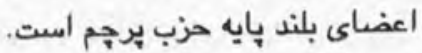

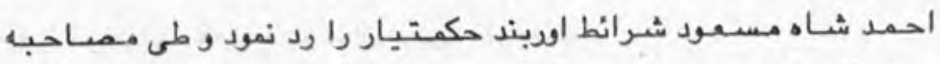

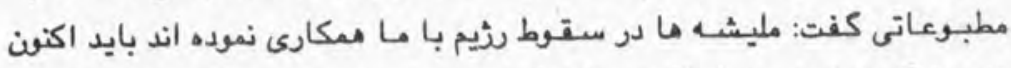

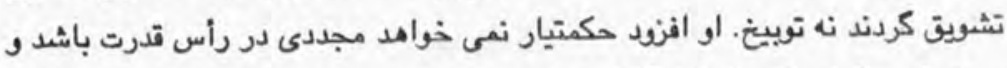

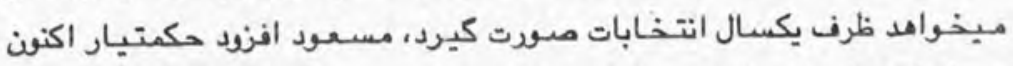

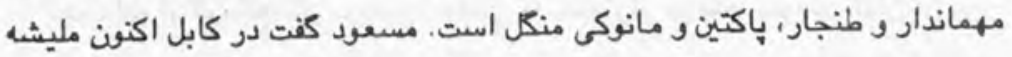
وجود ندارد مله مجامدين اند.

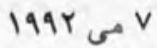


سياف كفت: تشكيل حكومت بـ معنى اثتلاف با كمونستهانيست، و حكومت

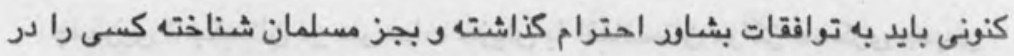

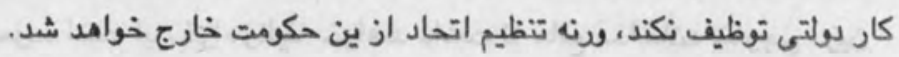
$199 \mathrm{r}$ (19

جنرال اسلم بيك رنيس قراى زمينى باكستان ابراز داشت: احمد شاه مسعود

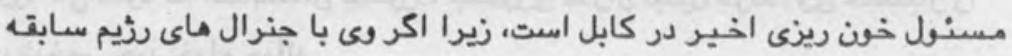
انتلاف نمى كرد و ميكناشت حكومت انتلافى مجاهدين تشكيل كردد حكمتيار مجبود

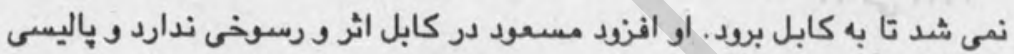

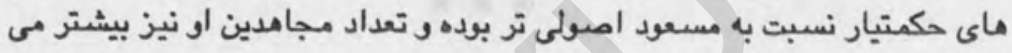
1994 م 9 باشند.

$8 \%$

حكتيار طى كنفرانس مطبوعاتى در شهر جلال آباد كفت: بايد مليشه ماى كم جمع از كابل خارج كردند، امنيت شهر را مجاهدين بسست كيرند، او افزود حزب با هيه تنظيمى در كيرى ندارد، و اكثر قوماندانان برايم نامه ما فرستاده و از موقف حزب مبنى بر خرج مليشه ها از كابل حمايت خود را ابراز داشته اند. 1997 مص 1.

شوداى جـادى طى جلسه ايى فيمله نمود تا جهار مزار طفلى را كه رثيم

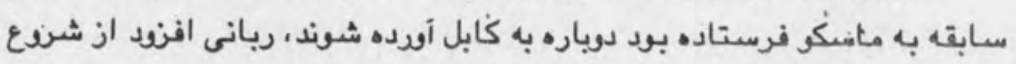

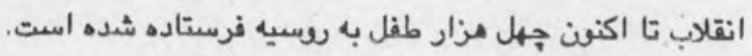
1994 r 11 
جمهرى تاجكستان در سرحدات خويش با افغانستان مراكز عسكرى جديدى

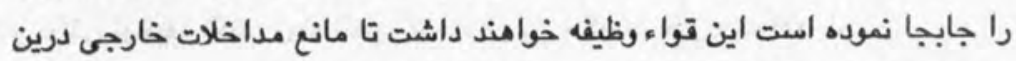

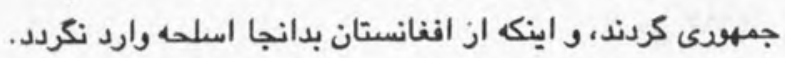

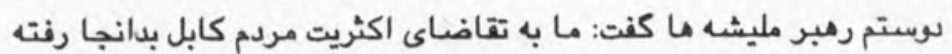

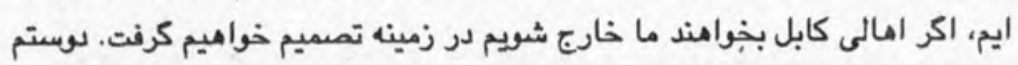

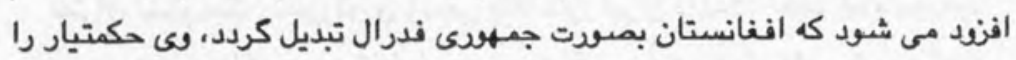

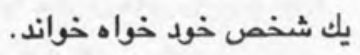

lagr ar

$\& \&$

منزل سفير سعودى در كابل از طرف اشخاص مسلح كه كفته مى شود جهل

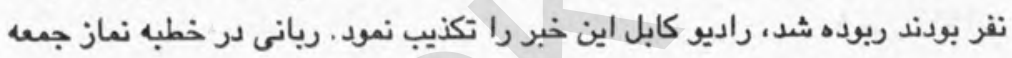

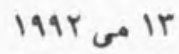
مردم سعودى را حامى جهاد افغان خواند.

$\$ 8$

بعد از ملاقات احمد شاه مسعود و كوزيروف ونير خارجه ربسيه يك اعلاميه

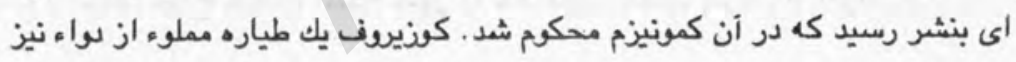

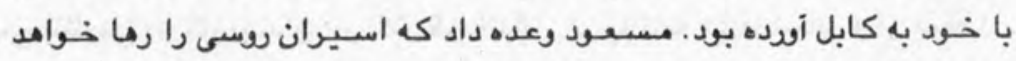

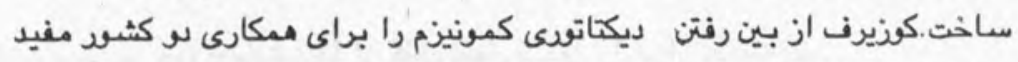

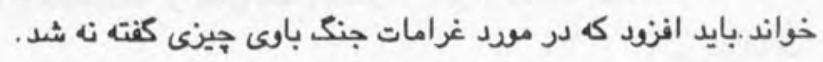
1 1994 
حزب وحدت كفته است: تا وقتى در حكومت جديد حققق اقليت هأ بـ رسميت

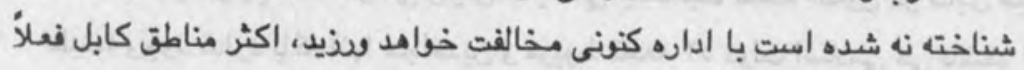
بتمرن اين حزب است.

10 مي 1999

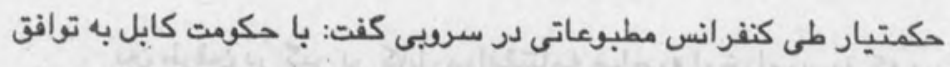

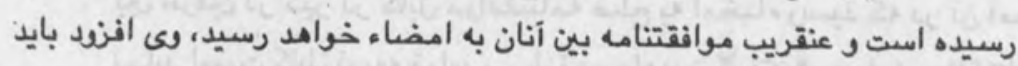
مليشه ما از كابل خارج كردند.

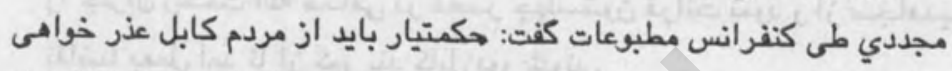
كتد زيرا باءث قتل عده ايى زياد مردم شد، او بايد عمل مفته كنشته خود را اشتباه 1994 IV بخواند.

\section{$\% \%$}

احمدشاه مسعود با يك عدها از شخميت ماى باكستانى كه در خمن آنها

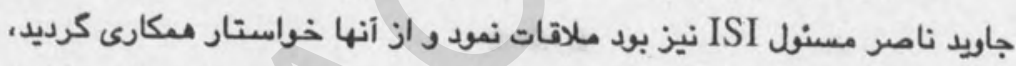

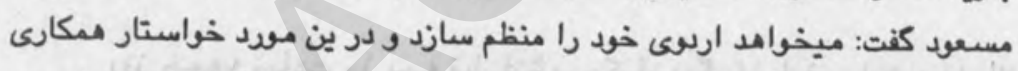

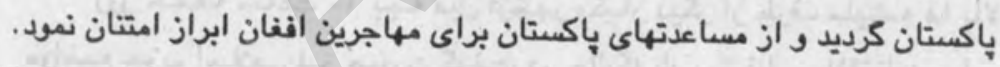
19 مي 19919

$\$ \approx$

حكومت جديد كابل اعلان نمود كه نميكذارد انقلاب از كثوش به بول همسايه la9r ror. مادر شود.

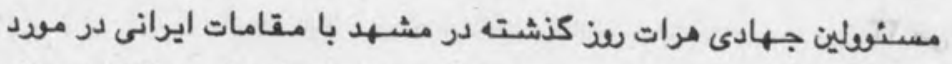

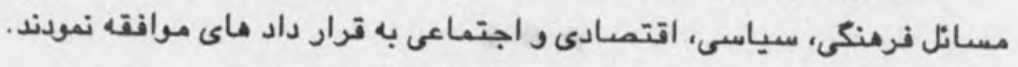
معلوم نيست كه اين نوع قرار داد ها به سود كثود است و و يا نهاء 
داكتر نجيب الله لفرانى رنيس سياسى جمعيت كفت: اكنرن در كابل ميهيه

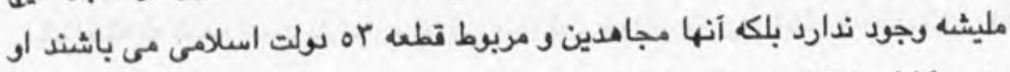
وضع كابل را قناعت بخش خواند.

1994 r.

$\$ \&$

بين طرفين در كير در كابل موافقتنامه ملح به امضاء رسيد كه در آن آمده

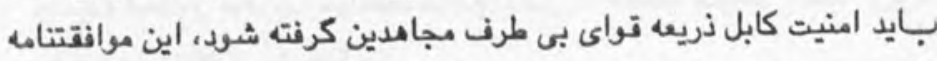

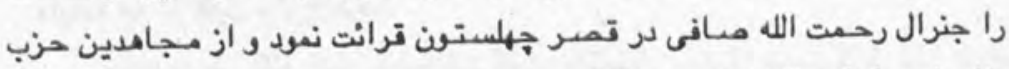

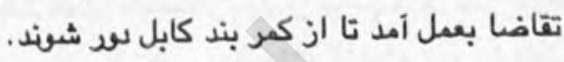
I99r

مجددى بعد از اعلان اين موافقتنامه عازم شعال افغانستان شد، وعى ميخواهد به تعداد طرفداران خويش بيافزايد. $199 Y$ Y Y Y

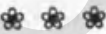

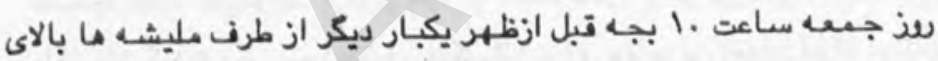

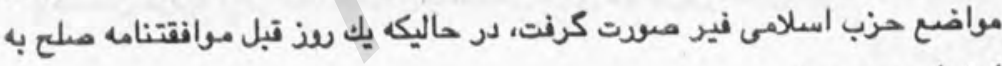
امضاء رسيده بود. مجددى در اولين ملاقات با سوستم كفت: دوستم مجاهد كبير بوده و از مدت

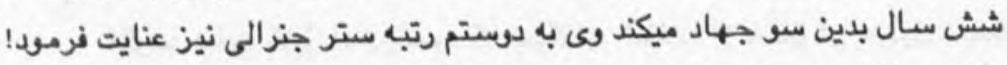

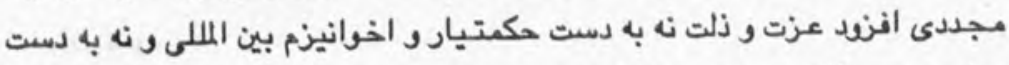

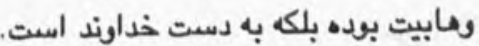
نطاق حزب اسلامى اين كار مجددى را تومين به مردم افغانستان خواند. I99r اعجـازالحت بسر ضياء الحق بخاطر از ميان برداشتن اختلافات مجـاهدين 
1994 م 19

امرن وارد كابل شد.

$\& \& 8$

حكمتيار و مسعود در شرق كابل ״بكرامى، با هم مدت هفت ساعت ملاقات

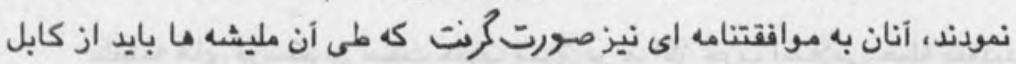
خارج و ظرف شش ماه انتخابات صورت كرفته و حكومت فعلى دوماه دوام كند. 1997 مي ro

مجددى طى سفر رسمى دو سذه وارد باكستان شد اين اولمين سفرى بخارج كشود بعد از تعيين شدنش درين سمت است. 199r مי

حامد كرنى معاون وذارت خارجه اتهامات مؤسسه حقوت بشر مبنى بر نقض

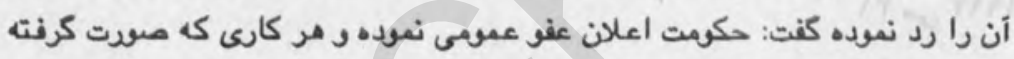
مربوط اشخاص بوده و حكمت را در أن دخالتى نبوده است.

I99T rV

$\$ 8$

محمد حسن جعفرى سخنكوى حزب الله كفت: شهر فراه بستت ما قرار دارد و

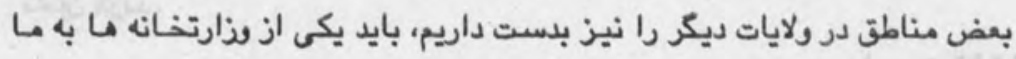

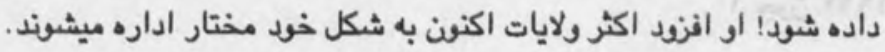
199 می TA

$\$ \$$

طياره حامل مجددى كه بيش از . . ا تن در آن سوار بودند در نزديك ميدان

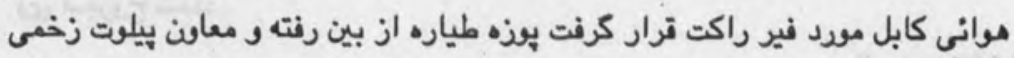

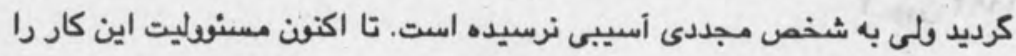

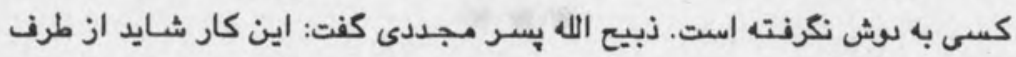


حوادث تاريخى افغانستان/

مجاهدين حكمتيار صورت كرفته باشد، در حاليكه حزب اسلامى اين عمل را تقبيع

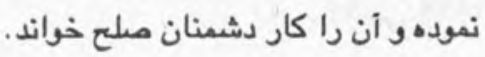

$$
\text { 1994 Ra }
$$

مليشه هاي دوستم در سمت جنوب شرت بر مراكز حزب اسلامى حمله نموند

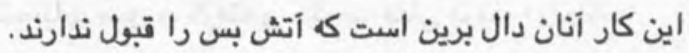

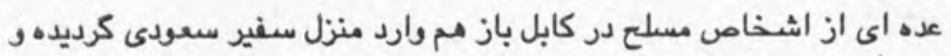
أن را مودد تاراج قرار دادند.

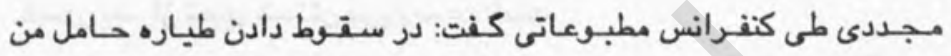

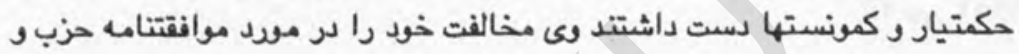

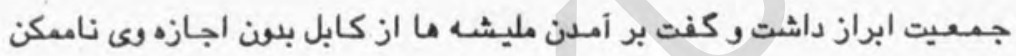
خوامد بود. 1994 M M

شوراى جـادى در قصر جهلستون تشكيل جلسه نمود، طى اين جلسه فير

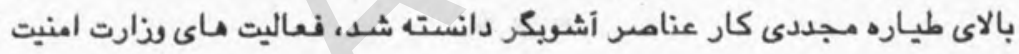

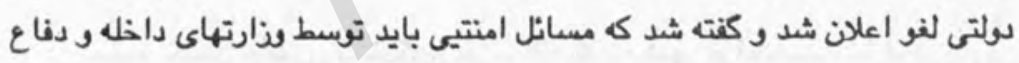
تأمين كردد. |

بر خدرد بين كرهه وحدت و كروه اتحساد در كرفت، حفانى كه ميخخواست ميانجيكرى نمايد مودد آتش نيروماى وحدت قرار كرفت و بو نفر از جمله محافظين

كى مجرح شدند. 1994 


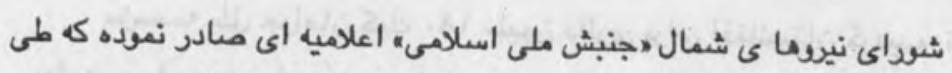

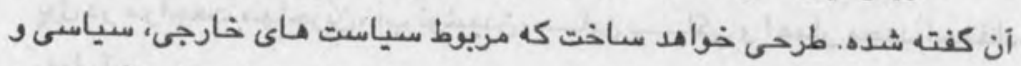

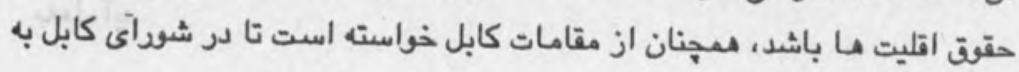
أنها جا داده شود.

بر خود بين هزاره ها و نيرعى ماىى اتحاد جريان دارد و هر دو طرن صدها

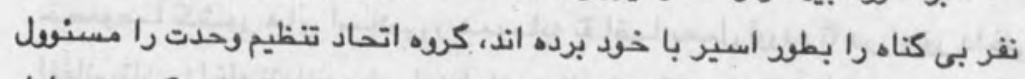

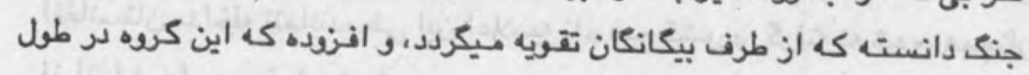

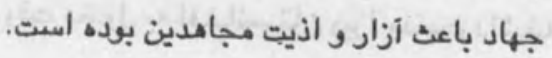

199r

$\$ 8$

حكمتيار اعلان نمود كه ما جريانات اخير كابل را دقيقاً بر رسى نموهد ودر

ع 1994

ين مود بى طرف ماند نمى توانيم.

$\$ \$$

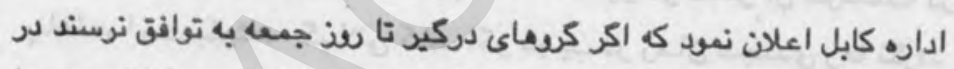

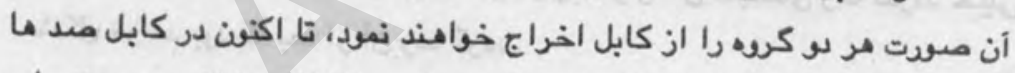

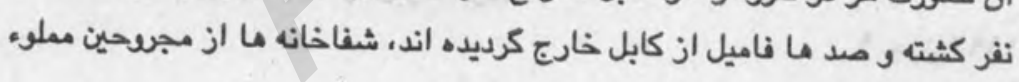
كريده است.

جنك بين كروه اتحاد و كروه وحدت به شدت جريان دارد، اكثر عمارات از بين

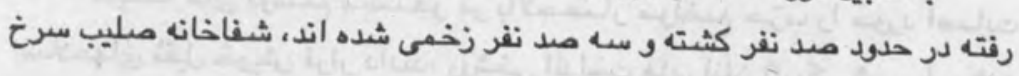
مملوء از مجروحين است.

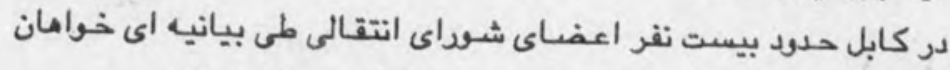
تشكيل لويه جركه كرديده و آنرا يكانه راه حل مسانل كنونى دانسته اند.

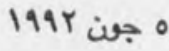


مؤسسه ملل خوامان كمك .11 مليون دالرى براى افغانستان كرديده، تا ازين

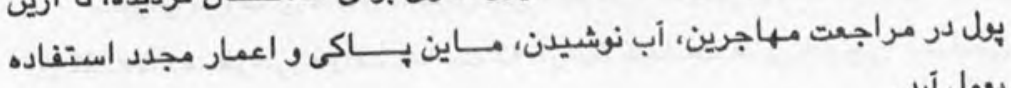
بعل آيد.

199r 199

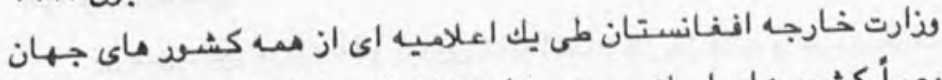

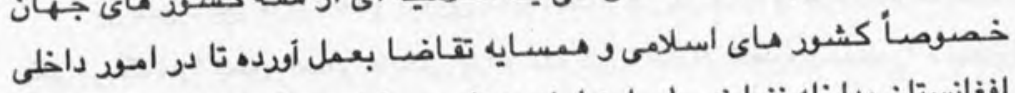

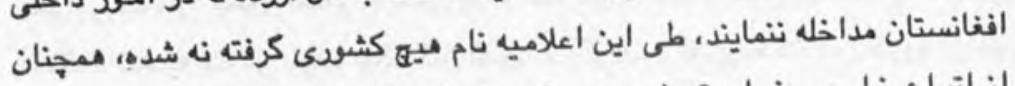

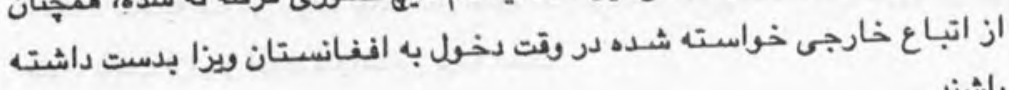
باشند.

جون V

سه سياست دان باكستانى مر يك افتخار كيلانى وذير عدليه زمان بى نظلير،

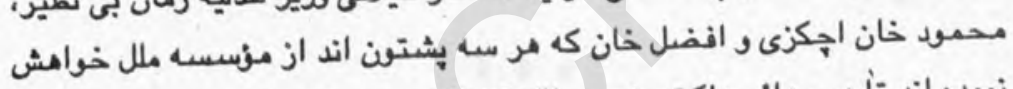

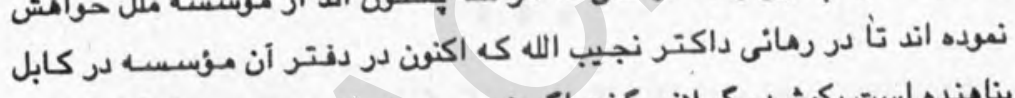

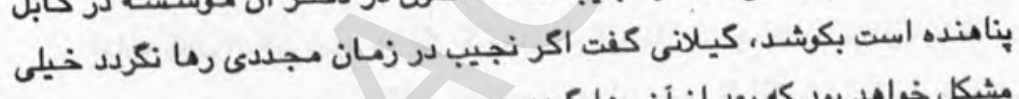

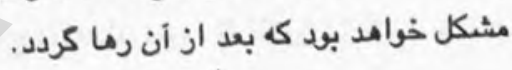
9 جون 1991

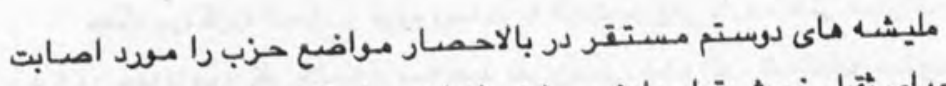

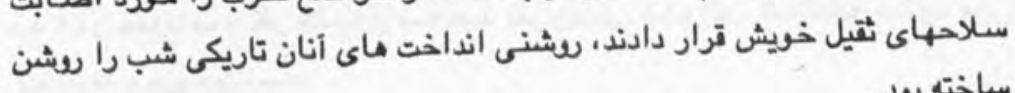
ساخته بود.

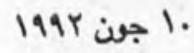

$\$ \&$

حزب وحدت موافقه نموده كه در حكومت انتقالى اشتراك وذذد مزارت امنيت به

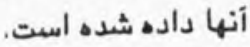


اولين شماره جريده مجاهد كه حامل بيام ربانى بود در كابل به نشر رسيد، اين

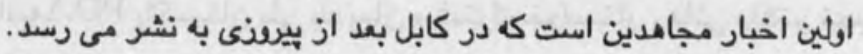
199r 11

جنرال متقاعد حميد كل سابت رنيس ISI باكستان به حكومت باكستان اخطار

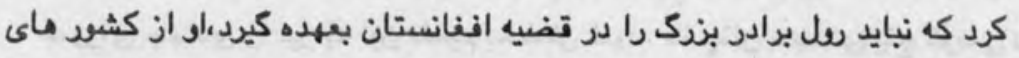

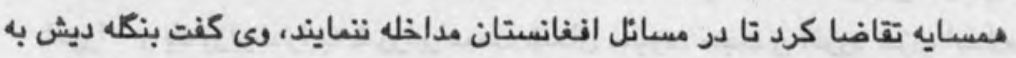

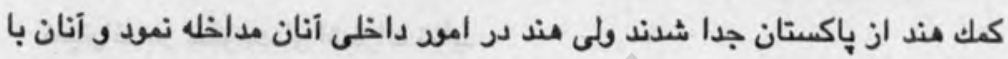

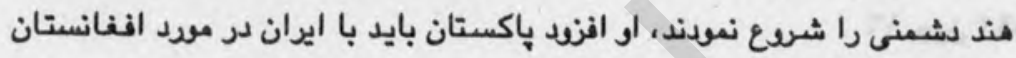

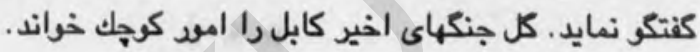

1

$\notin \notin$

يك تيم امريكانى به رياست بيتر تامسن وارد كابل شدند، أنان با مسنولين كابل

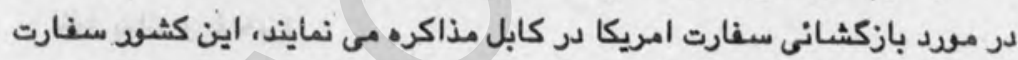

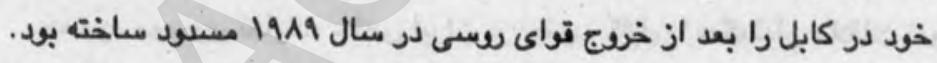
| 199 | 19

$\notin \notin$

هينت امريكانى طى كنفرانس مطبوعاتى وضع كابل را اطمينان بخش توصيف

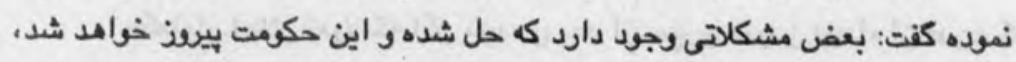

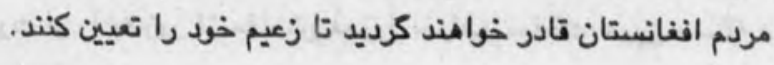

10 1991 جن 199

\section{\& \&}

غلام اسحق خان مدر باكستان با نمايندكان شش تنظيم جهادى در اسلام

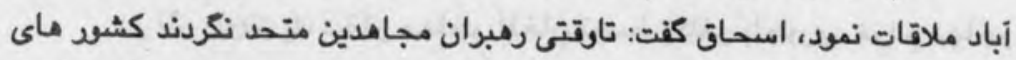

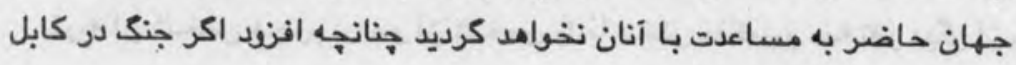


دوام كند باكستان بطود برامدار با آنان كمك نخواهد كرد.

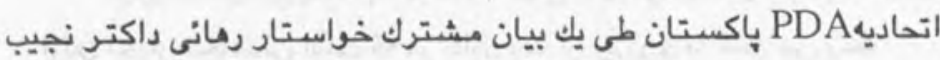
كرديدند، أنان كفتند ما در امود داخلى افغانستان مداخله نمى كنيم ولمى نجيب بايد باني

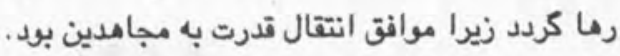

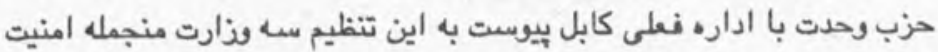

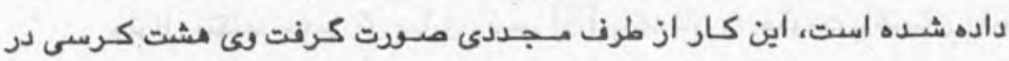

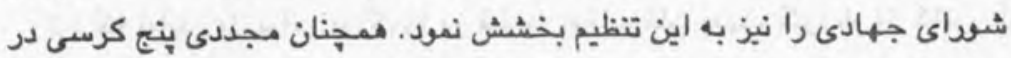

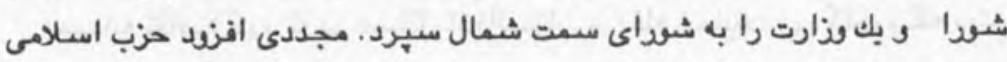
19 19 17 نميتواند در حكرمت او اشتراك نمايد.

مجددى رمبران مجاهدين را متهم ساخت كه از تعهدات خويش عدل نموده. اند، وعى رباني را متهب سـاخت كه در بهلوى حكومت او حكرمت ديكرى را تشكيل

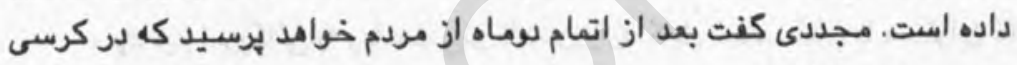
خود بماند و يا خير! محمو موسوى نماينده خاص ايران بر جنوب كابل با حكتيار ملاقات نمود، آنان در باره مساثل جارى افغانستان صحبت نمودند. IV

حكمتيار اعلان نمو كه اكر مجددى بعد از سبيرى نمون سوماه از قدرت كنار

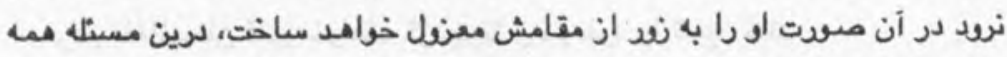
رمبران مجاها.ين متفق اند.

11 1199

$\& 88$

در ائر ربودن يك دختر مهاجر افغان توسط يكنفر باجوى، مردم مهاجر به

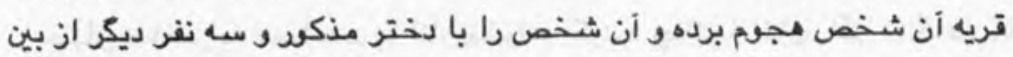


بردند. طى دركيرى جهل منزل تخريب شد حكرمت باكستان , ro مهاجر را بخاطر اشتراك در موضوع باز داشت نمودي.

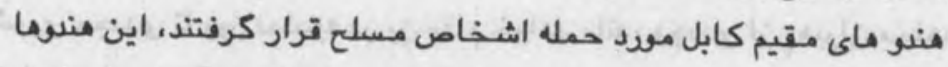

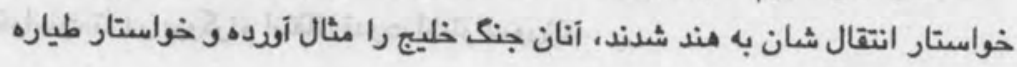

19

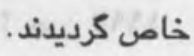

مجددى كفته است كه بعد از سبرى نمودن مدت خويش قدرت را بـ كميسيلن

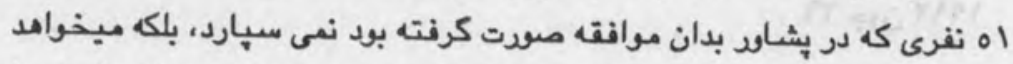

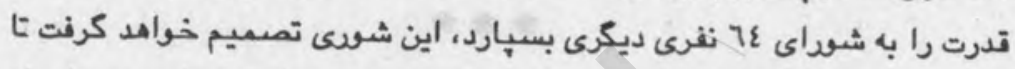

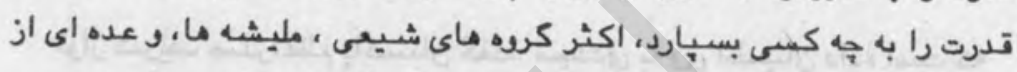

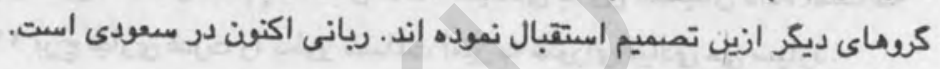

سومين جلسه حكمتيار در كرديز بود، وعى ابتداء در جلال آباد سيس در لغمان

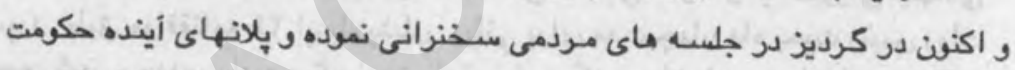

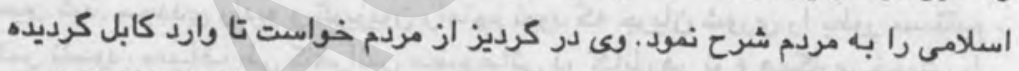

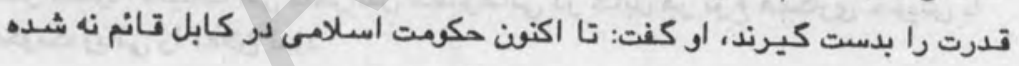
ا است، و افنود بايد كارمل و نجيب هر بو كو محاكمه شوند.

$\%$

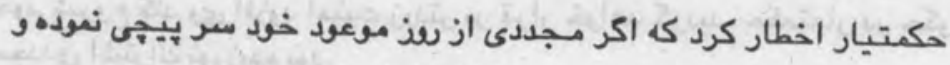

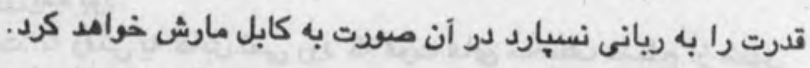

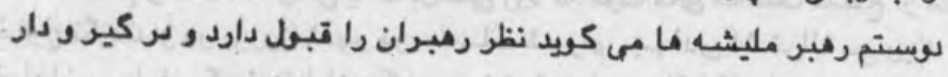
T طرف كسى را نمى كيرد. او افنوه كه كه بايد حقوق اقليتها حفظ شمو. 


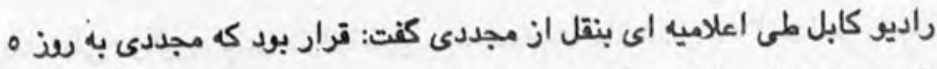

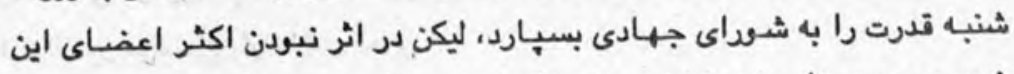

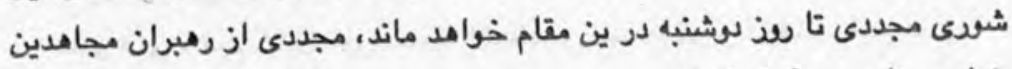

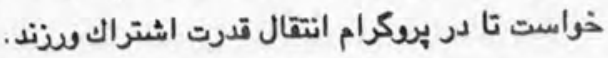

199r جون

به تاريخ ه .سرطان در شهر كابل برخود بين نيروماى وحدت و جمعيت در جرد

דri كرفت كه باعث كثته شدن عده اي از مردم كرئ كرديد.

$\notin \nRightarrow$

نواز شريف صدراعظم باكستان كفت: مجددى بـ هى اطمينان داده است كه

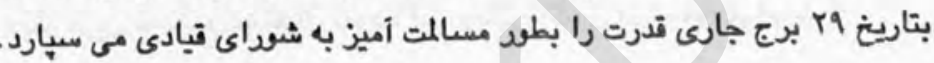

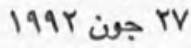

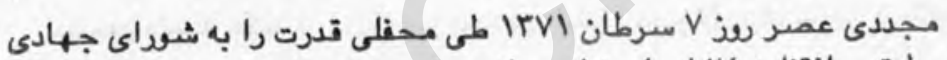

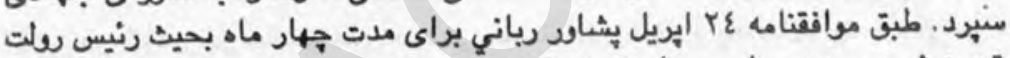

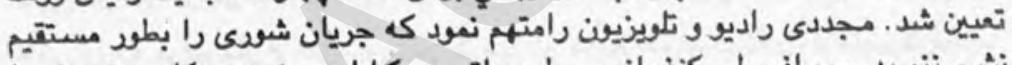

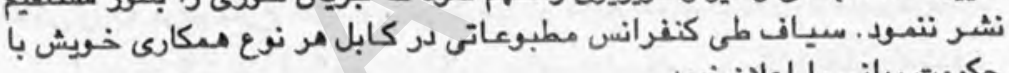
جن 1941

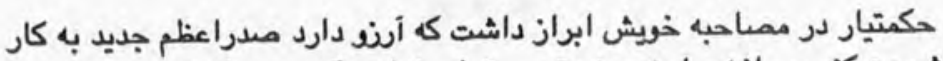

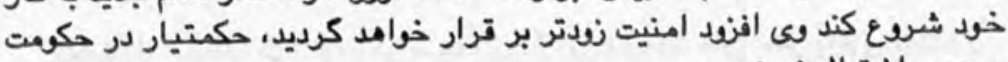

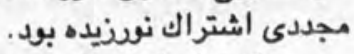

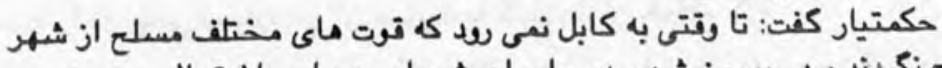

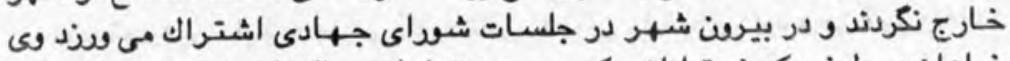

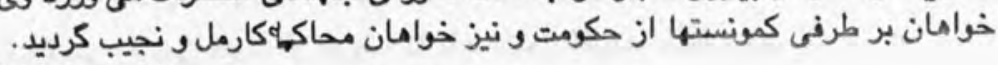

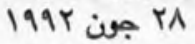


ربانى در اولين بيام راديو تلويزيونى خويش كفت: تبشكيل كربي هاى مسلح را

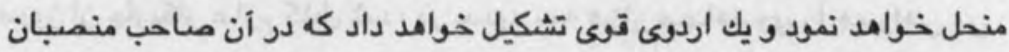

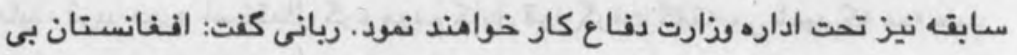

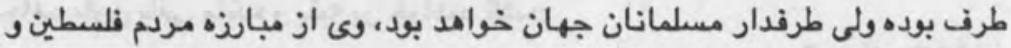

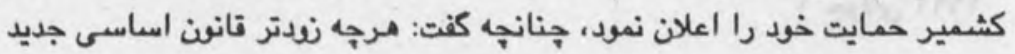

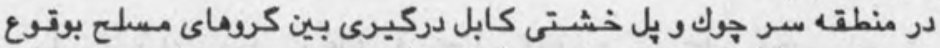

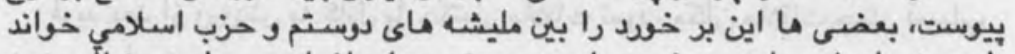

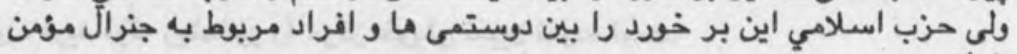

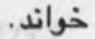
ب جولاي 199r

وذارت دفاع اداره كابل امرنذ خلع سلاح و بيرن كشيدن كريهاى مسلح از كابل را شروع نمود، عده اي درين باكسانى بقتل رسيدند. 199r

ايران بعد از جهارده سال اولين سفير خويش مصى الدين نجفى را بـ كابل

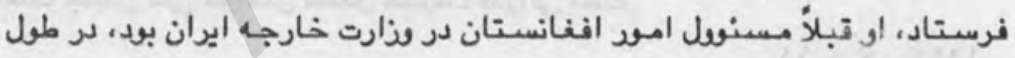

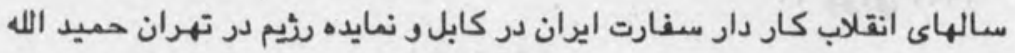
ناصر ضياءحضو داشت.

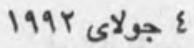

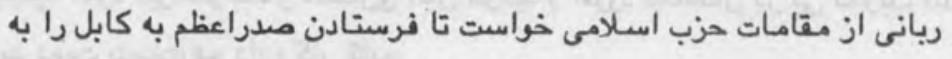

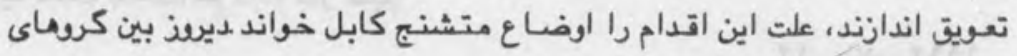
مليشه و مجاهدين بر خوددى صسرت كرفت.

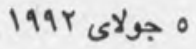


استاد عبدالصبود فريد اولين مدراعظم حكومت موقت مجاهدين بعد از ظهر

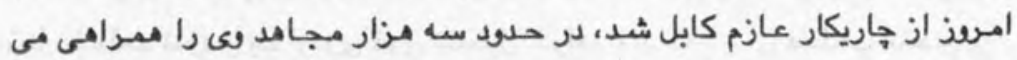

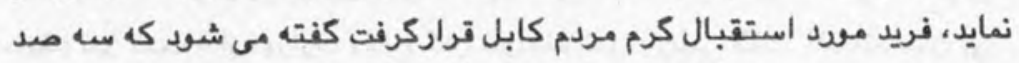
1994 (19) 1

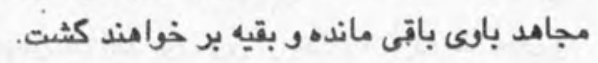
$\$ \$$

فريد بعد از صودش به كابل با حكتيار ملاقات نمود، مكان ملاقات جهار آسياب

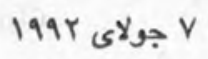

$$
\text { بود، فريد فرقه ريشخد را مركز خويش تعيين نموده است بان. }
$$

$\$ \&$

فريد از كشور هاى هسمايه ايرآ ، باكستان و نيز سعودى خواست تا در امود داخلى افغانستان مداخله تنمايند.

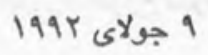

\section{$\$ \$$}

سيبد جعفر نادرى از طرف دوستم بحيث والى بغلان تعيين كرديد، او ابراز

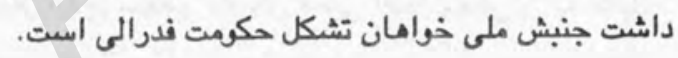
11

استاد فريد بر نامه عمل خويش را از طريق راديو و تلويزيون اعلان نمود كه إنه

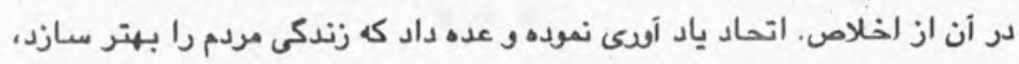

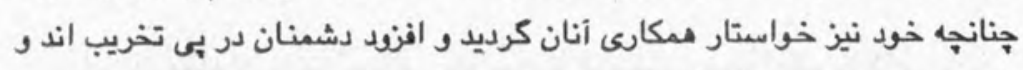
بايد دست بدست هم داده كار كثيم.

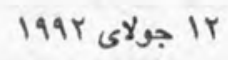


اولين هيـتت رسمى تاجكستان برياست اكبر شـاه سكندرف جـهت اظهار

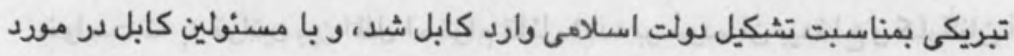
مناسبات سياسى، اقتمادى و فرهنكى صحبت نمود .

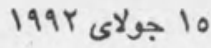

در منطقه كرته سنكى بين كروه وحدت و نير هاى رولتى جنك شديد در كرفت. هر بو طرف يكديكر را به أغاز جنك متهم نموده اند. 1994 17

استاد فريد طى مصاحبه اى كفت: سر از بذ شنبه نيرو هاى مختف از شهر

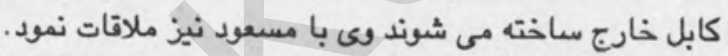
IV

\section{\& \& \&}

شواى قيادى طى جلسه اعى فيمله نمود كه بايد نيروماى مسلح از شهر كابل

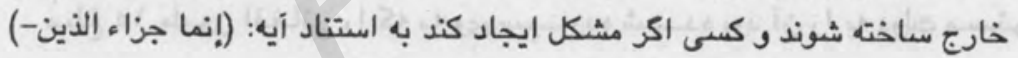

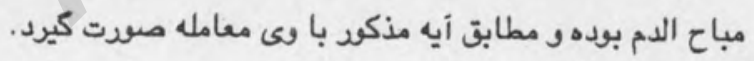

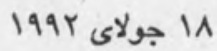

در اثر بر خود بين كروه وحدت و كروه اتحاد عدهء زيادى از مردم بقتل رسيده

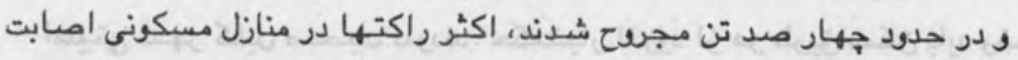
19 جولاى 1994 نمود. 
مـؤسسه صليب سرخ كه در كابل فـاليت دارد از اطراف دركير در كابل

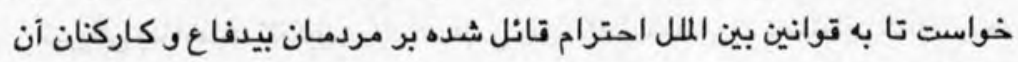
اداره فير نتمايند.

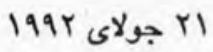

$\& \&$

مولوى خالص كفت: مادر دركيريهاى كه بين اتحاد و وحدت جريان دارد بى

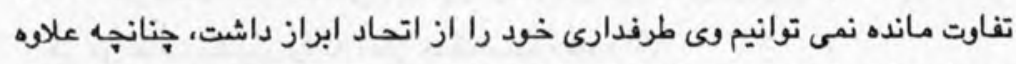

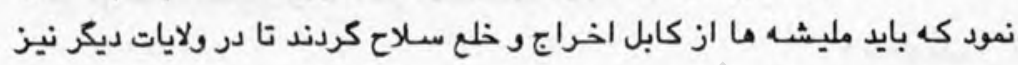
دست به جهد و جياول نزنتد.

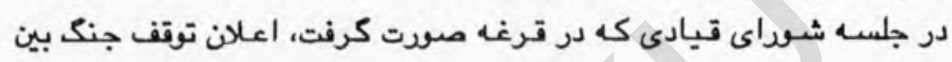

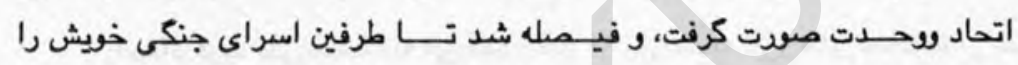
رما سازند.

توماندان عبدالحق كه از طرف مجددى بمفت قوماندان امنيه تعيين شده بود

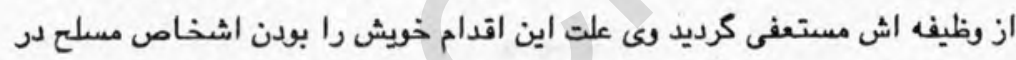

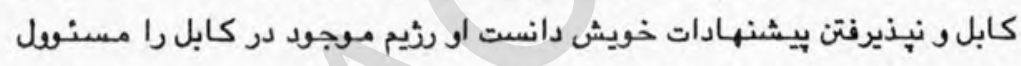

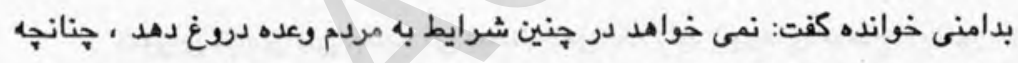

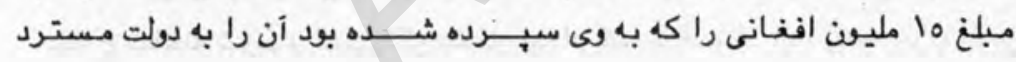
نمود.

ا Tr جولاى 1994

$\$ \&$

استاد فريد در جهار آسياب با حكمتيار ملاقات نمود. أنان درباره مسائل

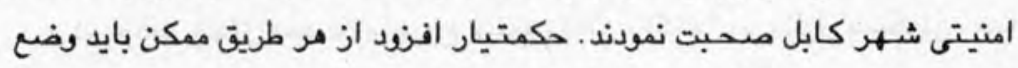
امنيت در كابل بهبود يافته و مردم در امنيت ور اطمينان زندكى نمايند.

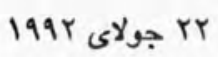


حكتيار از اداره كابل خواست تا امنيت شهر توسط وذارت داخله كرفته شده،

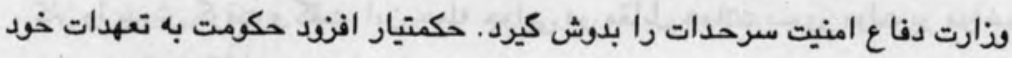

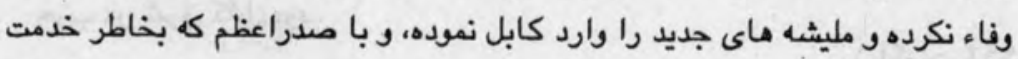

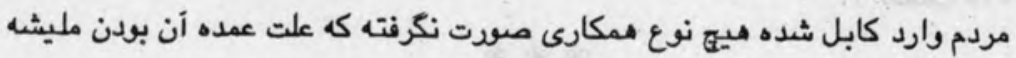

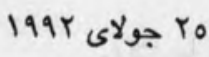
ها در كابل است.

وذير دفاع از منظمات حزب اسـلامى،اتحاد وروحدت براى خويش معاونين بركزيد. عبدالاحد ولسى كه در زمان تره كى والى غزنى و زمانى هم سفير بود، اكنف

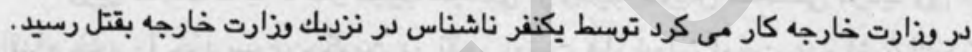

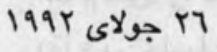

علاءالدين بروجردى معاون وذارت خارجه ايران كه اكنف در كابل حضود دارد

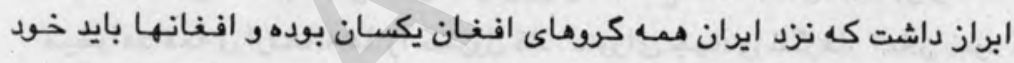
اختلافات خود را حل كنتد، وى افزود ايران تتها با حزب وحدت همكارى نمى كند.

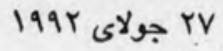

مولوى مير حمزه بحيث معاون رنيس جمهود و كفيل رياست جمهوى تعيين

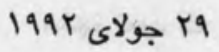

جين در حدود دو صد افغان را كه بطود غير قانونى وارد آن كشود شده بودند از خاك خويش. بيرن كرد.

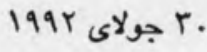


فردكادكابل هدف حملات موشكى قرار كرفت، حزب اسلامى مسنوليت اين

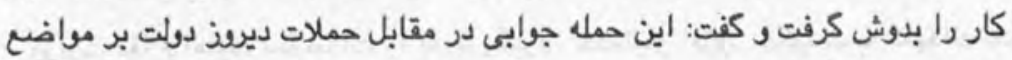
1994 199

ربانى طى فرمانى ملا نبى را بحيث معاون خويش بركزيد، در حدود . 10 فير

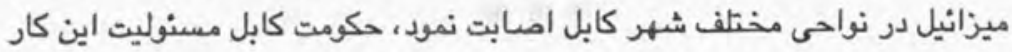

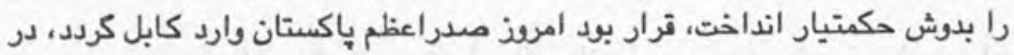

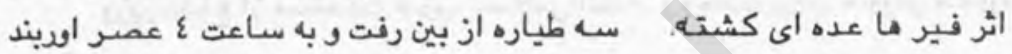

$$
\text { صورت كرفت. }
$$

وذير صحت عامه داكتر نجيب مجددى از وظيفه خويش مستعفى كرديد رى اين

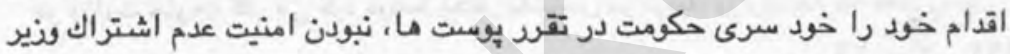

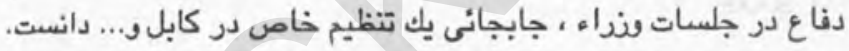

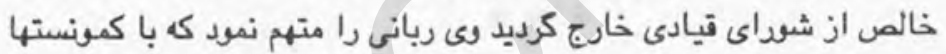

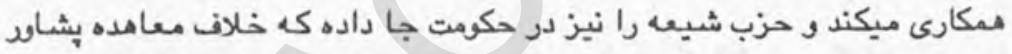

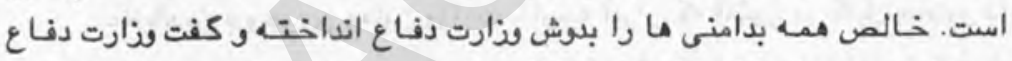

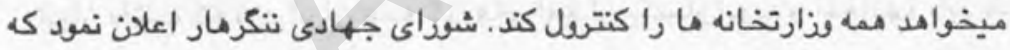
1994 اكست

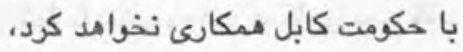

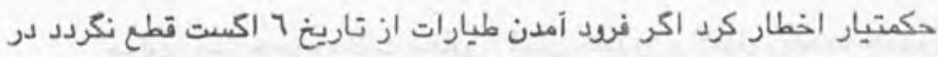

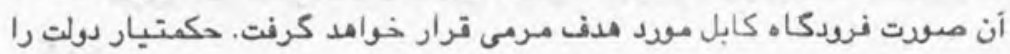

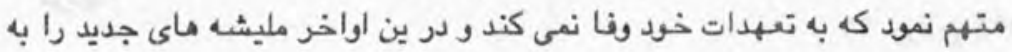

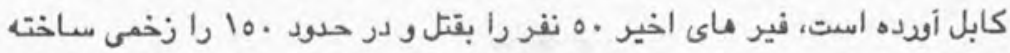

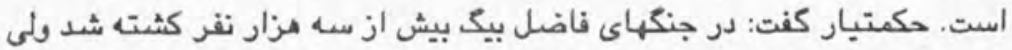
كسى بر أنها تأسف نتمود 
استاد فريد صدراعظم افغانستان وارد باكستان شد، او ابتداء وارد جلال آباد

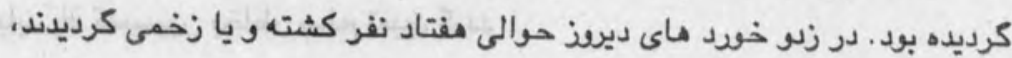
V اكست 1997 V

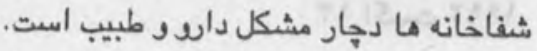

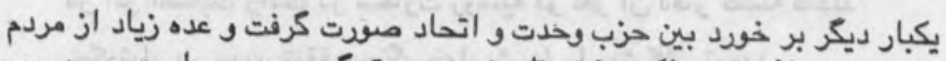

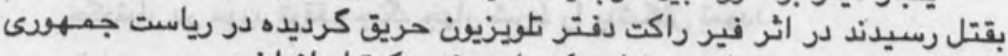

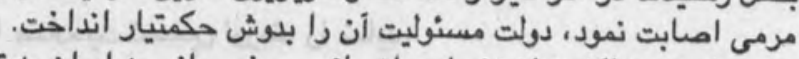
تلويزيون اكنون از نشرات باز ماند و سفر ربانى بـ بـ ايران به تعويق افتاد.

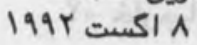

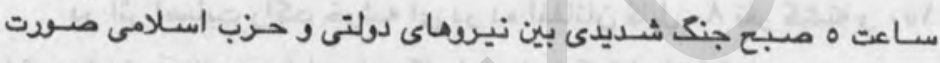

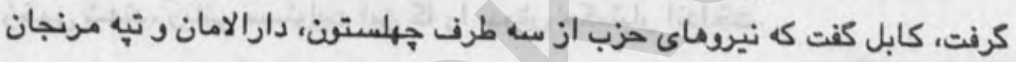

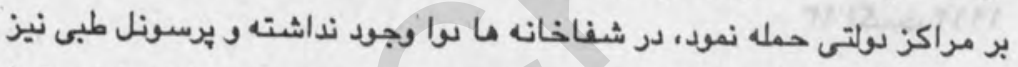

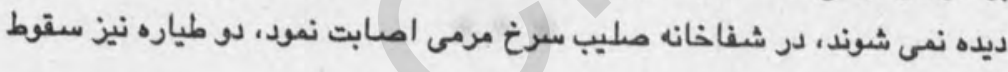

$199 r=$ داده شد.

\section{$\& 8$}

در حسود هزار راكت در مناطق مختف شـهر كابل اصابت نمود، در ميدان

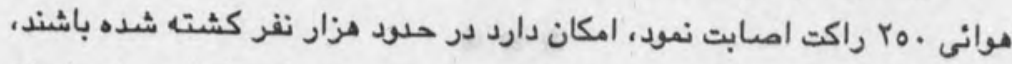

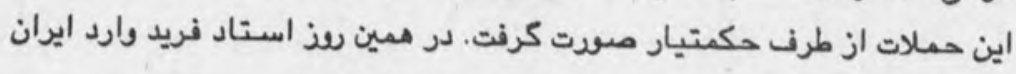
$199 r$ ISIII

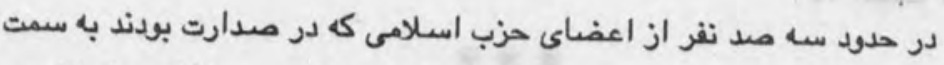

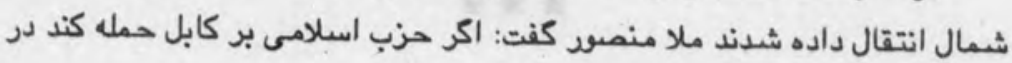


آن صورت بر مراكز حزب حمله خواهد كرد، و قاد اين جنكها را تقبيح نموده كفت: بايد يك كميسيون بخاطر صلح تعيين كردد .

r I اكست 199r

در اثر اصابت راكت در سفارت سبسيه بو نفر أن دفتر كثته شدند.

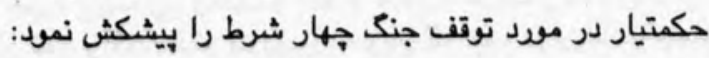

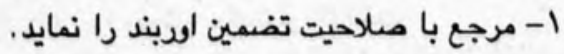

r- خارجيان ذريعه موتر از كابل خارج كردند.

r- محبوسين مربوط حزب از كابل آزاد كردند.

ع- أتش بس از جانب مقابل عملى كردد.

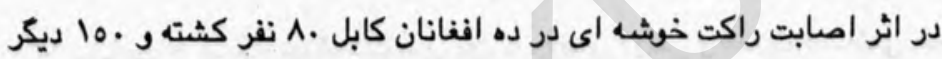
زخمى شدند، ربانى مسنوليت اين كا را ببوش حكمتيار انداخت.

199r

$\& \& \&$

جنك به شدت جريان دارد مردم كابل در حال فرار مستند، محبس بلجرخى مردي

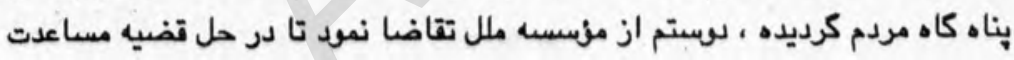
نمايد. 199r

$\$ 8$

ربانى از كشود ماى جهان خواست تا دناتر حزب اسلامى را در كثـد ماى ماى

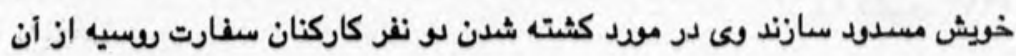
كشور معذرت خواست. $199 r$ 19 19 
انجنير احمد شاه احمد زى ونير داخله از طريق راديو كابل اعلان كرد كه من بعد بين حزب اتحاد و حزب وحدت براي دانم آتش بس بر قرار كرديده است. ما اكست 1994

ربانى اعلان نمود كه من بعد حكمتيار عضو شوداى قيادى نيست.

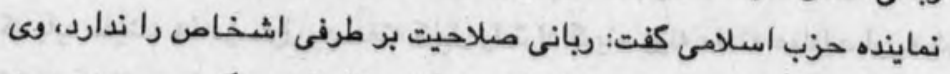

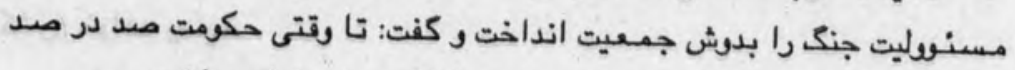

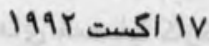
اسلامى در كشود قائم نكردد حملات حزب بر كابل جريان خواهد داشت واشت

$\$ \&$

طرفداران مسعود ميدان موانى شيندند را مود هدف مرمى قرار دادند، ربانى

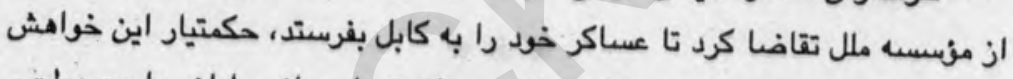

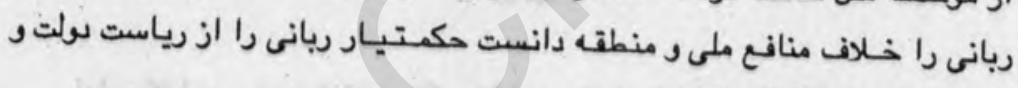
$199 r$ II I I شواى قيادى عزل نمود!

$\& \&$

عده اى از توماندانان بخـاطر توقف جنك وارد كابل كرديدند، اين مطلب را

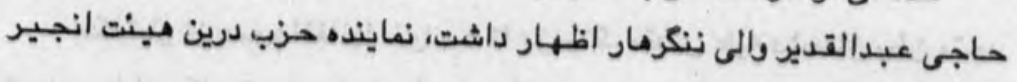
1994 19.5 19

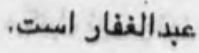

ربانى وضع كابل را بحرانى تلىى نمده از ايران تقاضاى كمك كرد.

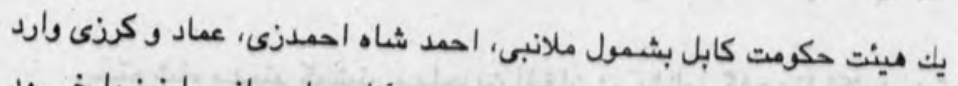

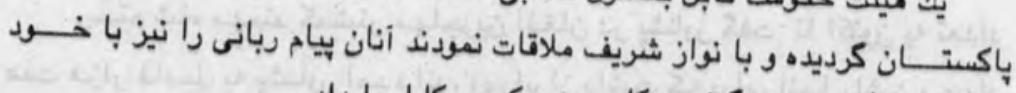

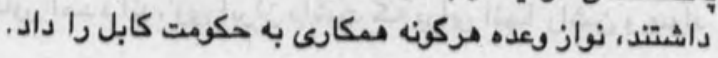




\section{Ar حوادث تاريخى افنانستان/}

عده اي از مردم كابل كه در اثر جنعها فرار نموده بودند، وارد تاجكستان

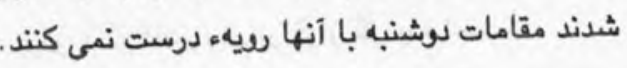

|Y اكست I99Y

حكمتيار بخاطر بيرن شدن اتباع خارجى به أتش بس تن داد، وى اخطار كرد كه بايد مليشه ها در طول يك هفته كابل را ترك كويند ورنه دامنه عمليات او بـ شئ شمال كثرد خواهد رسيد.

فرانسه و بريتانيا سفارت خانه هاع خويش در كابل را مسلود نمودند، كشود

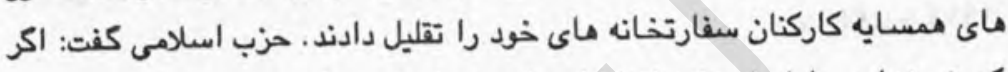

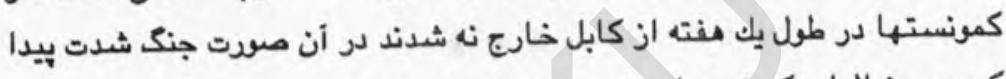

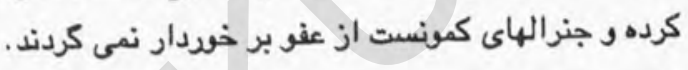

199r

$\notin \%$

اداره كابل در مودد توقف جنك بخاطر دبيلوماتها اظهار أمادكى نتمود و كفت در مود خارج شدن با آنان مساعدت مى كنيم ولى جنك را ترقف نميدميم.

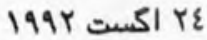

حكتيار از عموم افنانها خواست تا در جنك مقدس عليه دشمنان وطن متحد

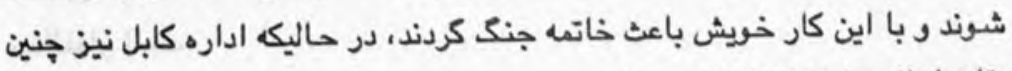
تقاضاهانى را از افغانها مى نمايد.

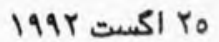

رستم شاه مههند كمشنر مهاجرين افغان در يشاور كفت: تا اكنون به تعداد

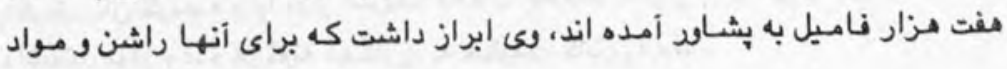


خواكه داده خواهد شد.

خالص و ملا نبى به كابل رفتند، أنها ميخوا هند با حكمتيار ودربانى ملاقات نموده در مود توقف جنك به نتيجه برسند. 199r 199 19

استاذ فريد كه اكنون در ارياست طى مصاحبه كفت: ما وقتى كابل را ترك

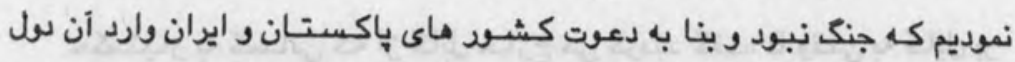

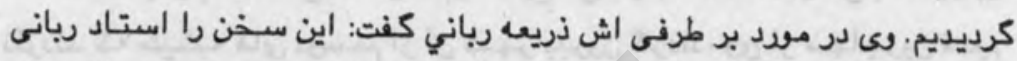

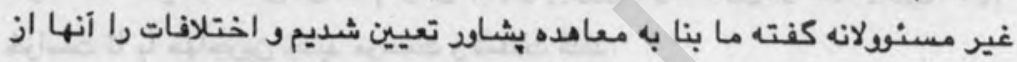
$199 r$ Trت 197

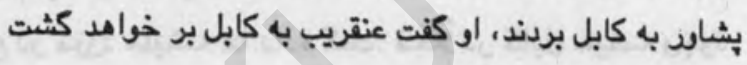

خاكستان از اطراف در كير جنك در كابل خواست تا از ساعت با بجه اليوم

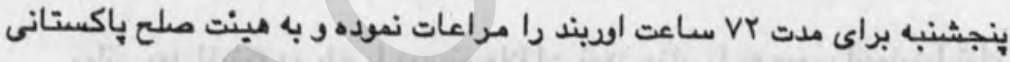
اجازه دهند تا در مرد معاهده بشاود با اطراف در كير مذاكره نمايند. 199Y نو 19

حكومت كابل براى ده ساعت الربند را اعلان نمود تا دييلوماتهاى خارجى از

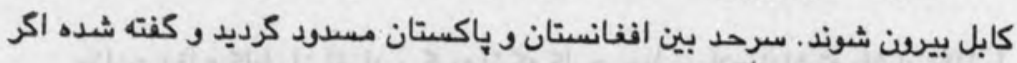

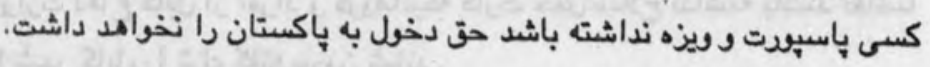

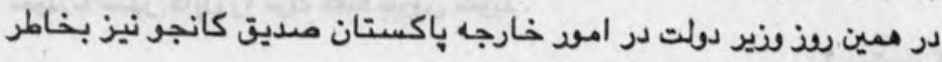
مذاكره با اطراف دركير وارد كابل شد.

1 اكست 194T 
توماندان شمالى كفت: ربانى و حكمتيار هر بو موافقه نموده اند تا معاهده

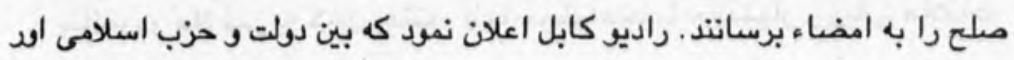

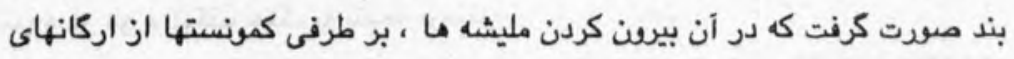

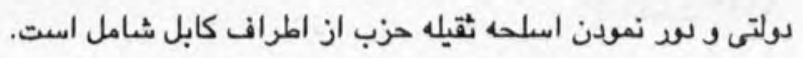

1994 r 19

حكمتيار به كسـانى كه از كابل خارج مى كردند كفت: تا وتتى به كابل بر

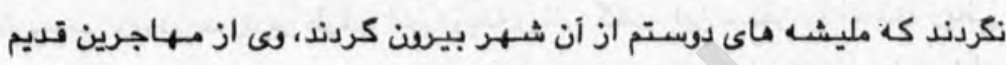

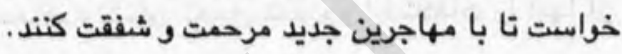

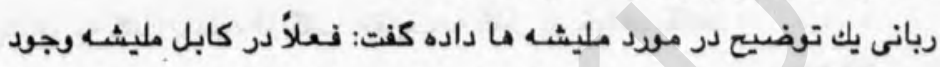

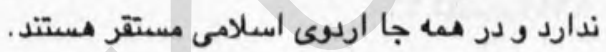
199r اكست.

\section{$\& \& 8$}

ربانى بعد ازينك در بلخ با سوستم ملاقات نمود مزار را بـ سوب انرنيزيا ترك

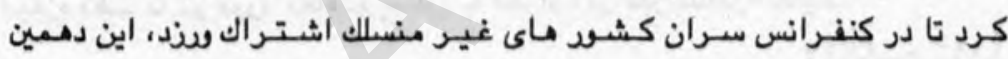

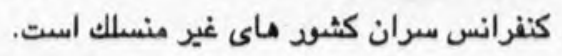

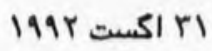

وذارت دفاع كابل از افراد و كرمهانيكه كارت حمل سلاح نداشته باشند تقاضًا

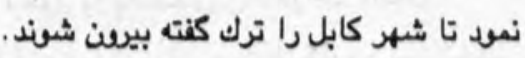

199r r

در اثر سيلاب هاى طبيعى در شمال كابل، (يل متك، غنربند و كلبهار) مزاران

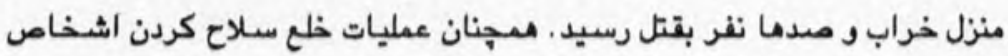


$199 r$ r 19

$$
\text { مسلح نيز در كابل شروع شد. }
$$

ربانى در جلسه جاكارتا از رسسيه تقاضاى برداخت غرامات جنك تحميل شده

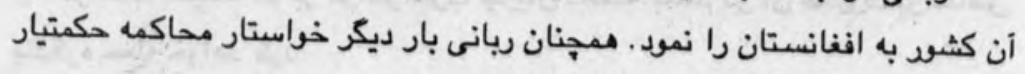

$199 r$ \& 19

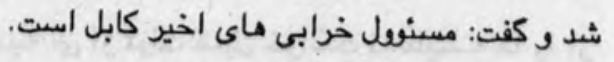

$8 \%$

باكستان در حدو دو مد نفر سك باشنده افغانستان را كه در جنكهاى اخير $199 r$ 1970 7 به آن كشود بناه برده بودند از خاك خود اخراج كرده است. بـان.

بعد از كنشت بيست سال براى اولين مرتبه سه نفر متهم به سرقت در محفر عام در شهر كابل به دار آويخته شدند، اين الشخاص متهم به قتل نيز بودند.

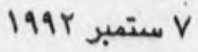

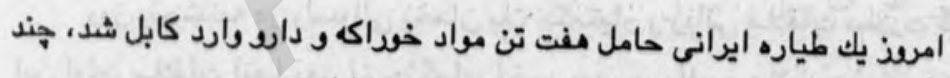
9 ستمبر 994

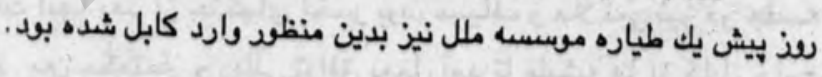
$\notin 8$

ربانى لن جمس را بخاطر كثت شدكان جنكهاى اخير كابل سنماتم ملى اعلان كرد.

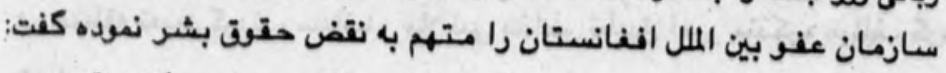

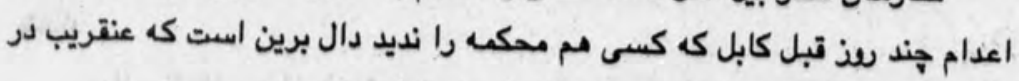
1997 11

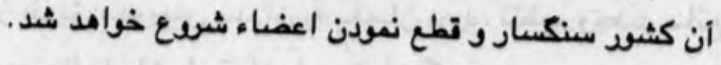


حزب اسلاهى بخاطر ميانجيكرى هيأت صلح از حمله بر ميدان هوانى كابل و

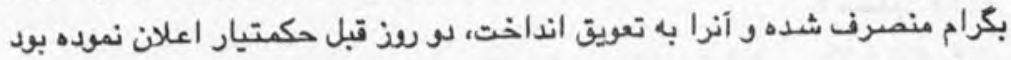

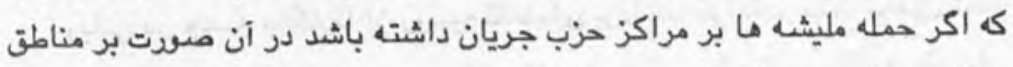

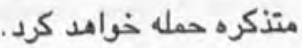

حزب اسلامى طى يك اعلاميه اي از دولت كابل خواست تا مليشه ها را را از

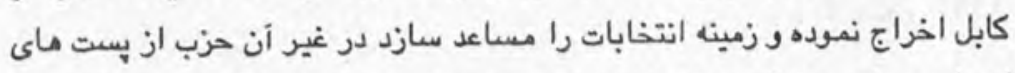

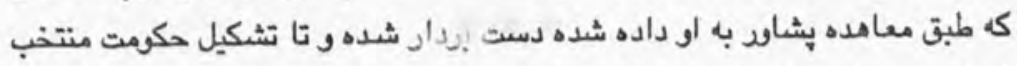

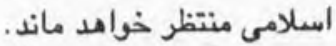

199 19

$\$ 8$

بار ديكر جنك بين حزب وحدت و اتحاد در منطقه كوته سنكى در كرنت، جنك

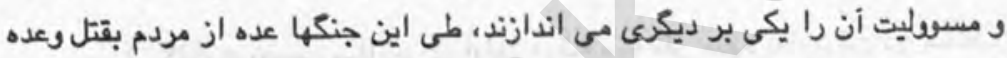
اي هم زخمى كرديده اند.

l99ץ lV

$\& \&$

رذ ينجشنب در ولموالى بغمان بين حكتيار و ربانى ملاقات صورت كرفت،

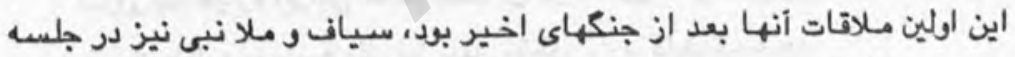

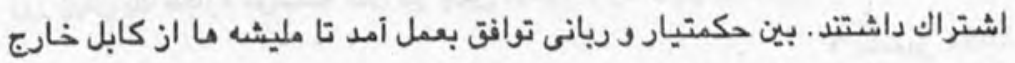

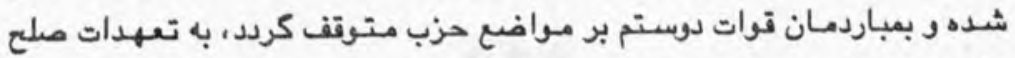

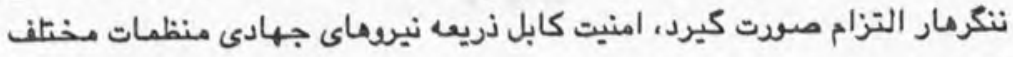

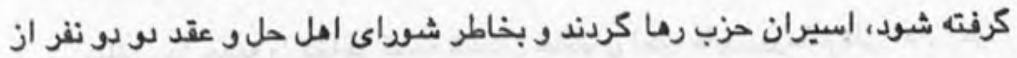

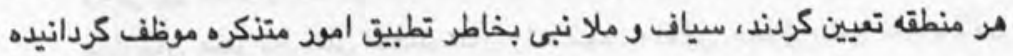
شدند. ربانى نتـوانست از طريق ميرويس ميدان بـ بغمان برود، تتظيم وحدت مـانع

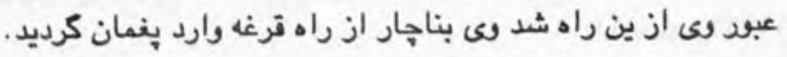
19 ستمبر 199r 
بين حزب وحدت و اتحاد بارديكر الوبند بر قرار شد، اين جهارمين موافقتنامه صلح بين طرفين مى باشد.

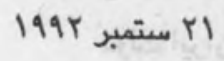

$\notin \notin$

حزب وحدت بيوستن خود با حكومت فعلى كابل را اعلان نمود، اين تنظيم در

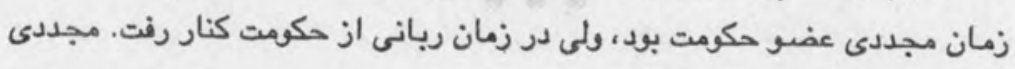

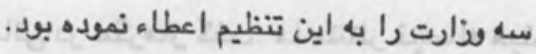

199r r

ربانى وارد بشاود شد، وكى فردا با اسحق خان صدر هاكستان خواهد ديد،

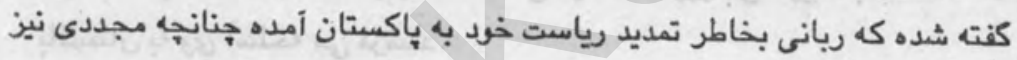
I99Y ro

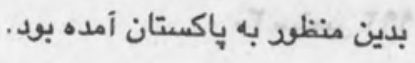

ربانى سه وذارت را به حزب وحدت داد، عبدالواحد سمرابى، مولوى احمد ننلر

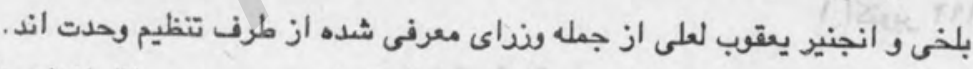

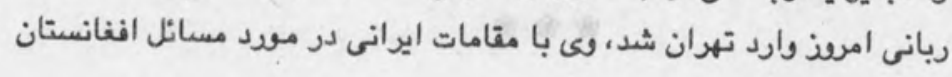
I99T YV TV و.... - محبت خواهد نمود وان.

\section{$\notin 8$}

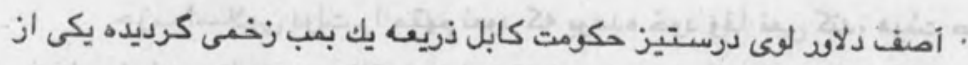

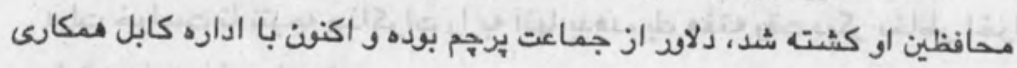

Y 1994 
امروذ جهار نفر ديكر درّاّرك زرنكار كابل بدار آويخته شدند، كفته شده كي

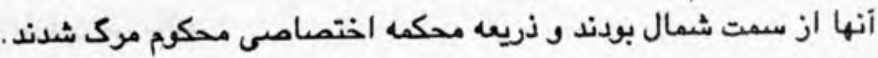

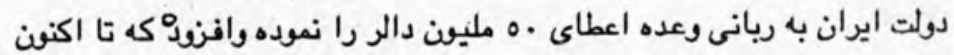

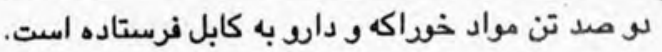
199r r.

حكمتيار طى كنفرانس مطبوعاتى در ننكرهار كفت: ما منتظر فيصله مينت

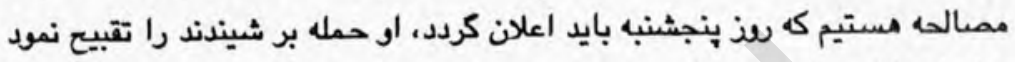

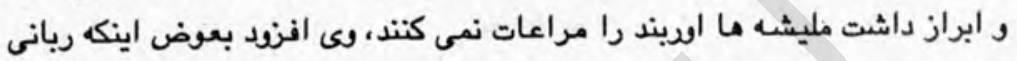

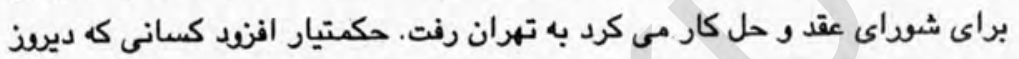

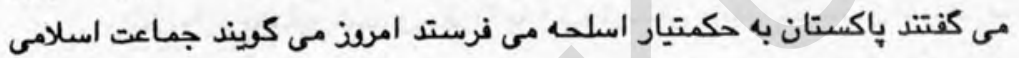
199r r. باكستان به وعى اسلحه مى فرستد.

راديو كابل طى نشر يك خبر سى نفر را در بست هاى حساس اربو مقرد نمود

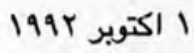

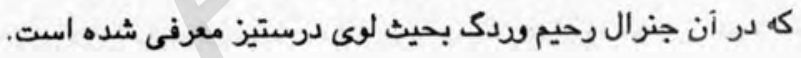

رحيم وردك كفت: اربو بايد بى طرف بوده و در امورات سياسى مداخله نكند.

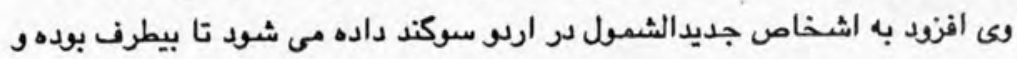

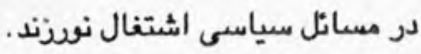

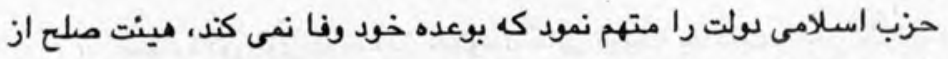

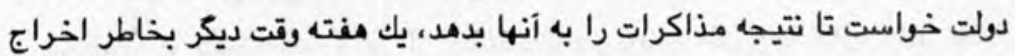
مليشه ها به دولت داده شد. r اكتوبر 1994 
دولت كابل موافقه نمود كه در ظرف يك هفته مليشه ها را از كابل بيرن سازد.

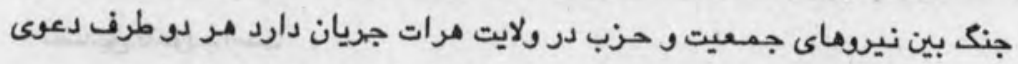

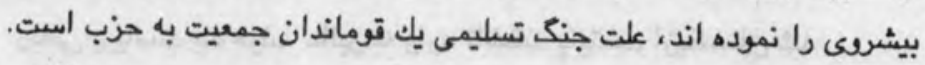
م اكتوبر 1994

ربانى از موسـسـ ملل و سـازمان كنفرانس كشـود هاى اسـلامى تقاضاى

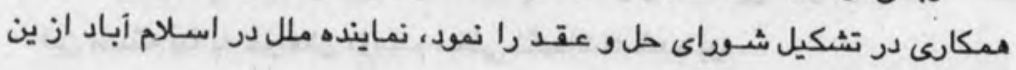
7997 تقاضاى رى اظهار خورسندى نمود.

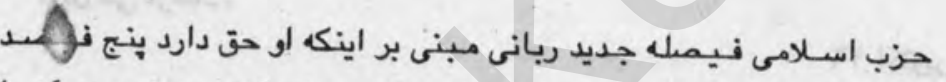

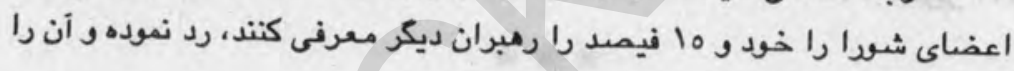

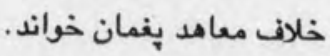

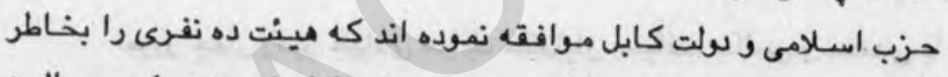

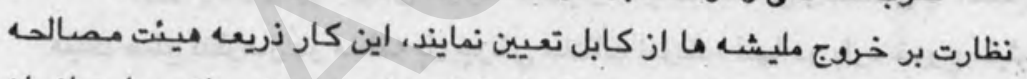

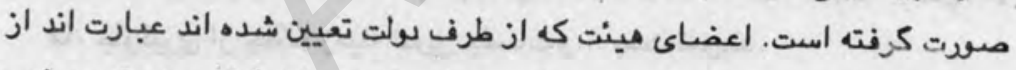

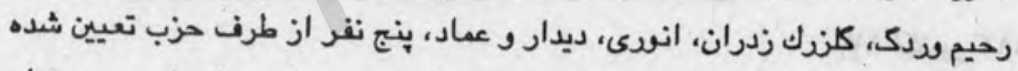

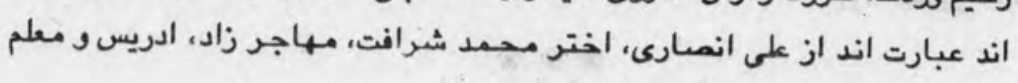
$199 r$ اكتوبر اكوبر

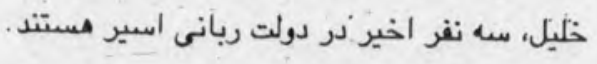

ربانى كفت: كسانى كه اوامر ما را تبول مى كنتد مليشه نه بلكه جزء اردوى اسلاهى شمرده مى شوند بدين سبب در كابل مليشه وجود ندارد. 199r نير هاى بولت توانستند كنترل ميدان هوانى شيندند را از نير هاى حزب 
اسلامى بدست أوند، حزب ميكويد جنك جريان دارد و تا اكنون خبر سقوط را تمديق نتموده است. بات اوند،

ربانى بريأست يك هينت عاليرتبه وارد تاشقند بايتخت ازبكستان شد.

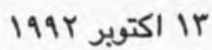

حكومت خاكستان سرد دوستم به باكستان را تصديق نمود ر كفت: تا اكنون اين مسئل بنا به خواهش دوستم مخفى نكهداشته شده بود.

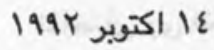

حكومت سعودى بيست و بنج هزار تن تيل را عنقريب از طريق ياكستان به كابل مى فرستد. 19

امرنذ جهار رهبر جهادى هر يث حكمتياز، سياف، خالص و محمدى با اعضاى

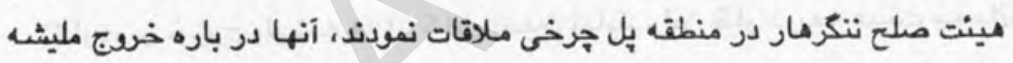

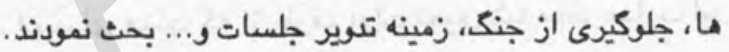

iv اكتوبر iq9

$\$ \& 8$

دولت كابل طى اعلاميه ابراز نمود كه در اخير ماه اكتوير قدرت را به شوايى

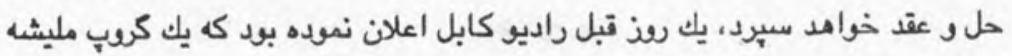

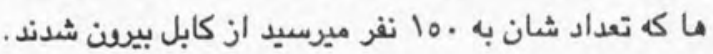

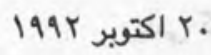

شوراى قيادى طرح تشكيل شوداى اهل حل و عقد را به تصويب رسانيده و 


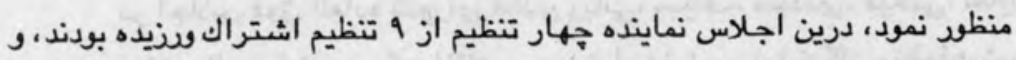
بع رنيس دولت حق داده شده تا ينج فيمد اعضاى شورى درى را انتخاب كند.

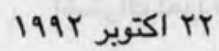

قاضى وقاد بيوستن بلا قيد و شرط خويش با حزب اسلامى را اعلان نمود، ويى

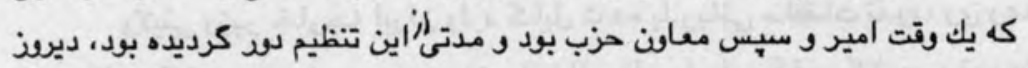

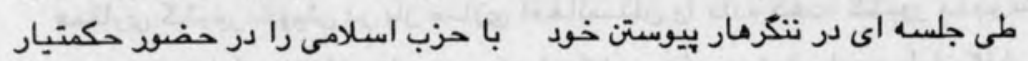
ابراز داشت.

199r

ربانى طى كنفرانس مطبوعاتى در كابل اعلان نمود كه سذ ب اكتوبر كه زمان

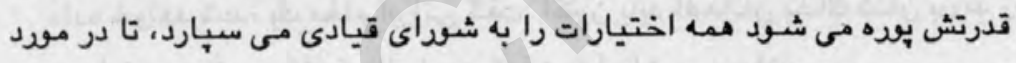
تعيين زعيم مؤت أينده تصميم بكيرند.

$199 r$ ro

قرار بود امريذ جلسه شوراى قيادى بخاطر تعيين زعيم آينده كشور تشكيل

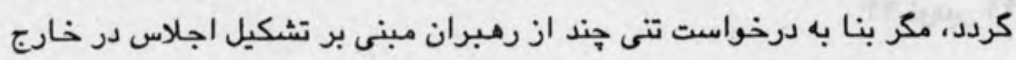

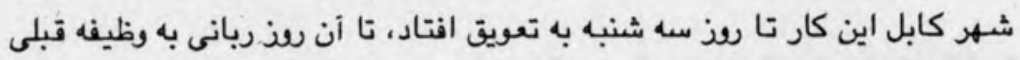
اش ادامه خواهد داد كاند 9

راديو كابل اعلان نمود كه در اجلاس فوق العاده شوراى قيادى كه در قصر

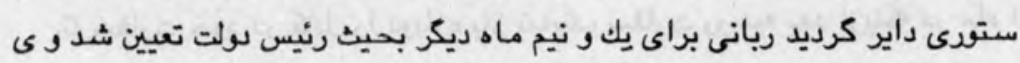

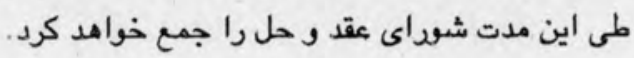


در اجلاس فوق العاده شواى قيادى ربانى، سياف، مجددى، كيلانى، نماينده

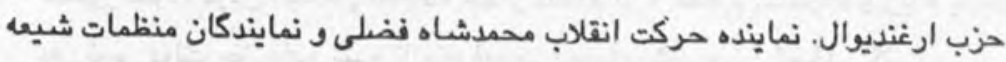

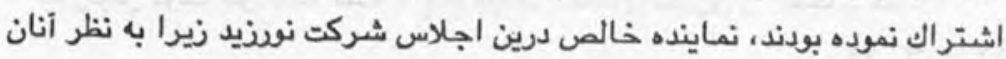
در كار هاى شوراى قيادى تمرفات بى مورد رخغ داده است.

اك اكتوير 199r

رلايتى هذير خارجه ايران وارد كابل شـده با. ربانى ملاقـات نمود، وي وعده

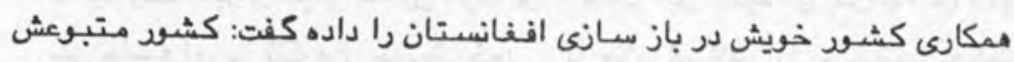

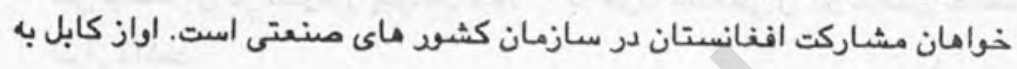

9 نومبر 1997 دملى رفت.

مقامات ايرانى و افغانى در مودد بازكشت مهاجرين افغان بخاك شان به توافق

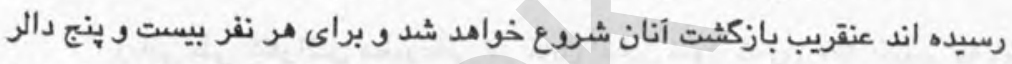

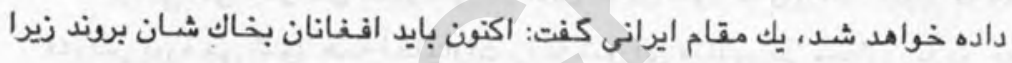
مصارف هر نفر سذانه ع دالر است كه آن را را ايران مي بردازئ.

1994 نومبر 19

هوستم سر كرده مليشه ها وارد سعود شد، اين خبر قبلأ خش شده بود و اكنفن به حقيقت بيوست. درين سفر بسر سيد كيان نيز دوستم را همرامى ميكند.

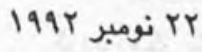

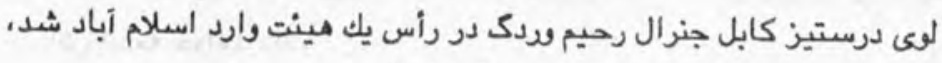
199r

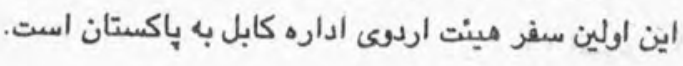

ربانى از هينت بلند بايه روبى برياست اندريوف كه وارد كابل شده خواست

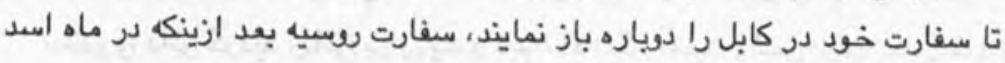




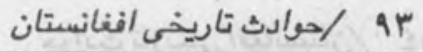

سال كذشته مورد اصلابت راكت قرار كرفت مسدود شد، مينت مذكود از مسنولينين كابل يكبار ديكر تقاضاى رهانى اسراى خود ران ران نمودند.

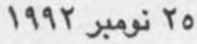

$\& \& 8$

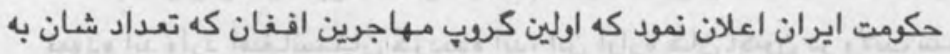

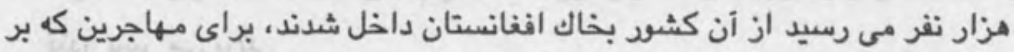
مى كردند بيست و ينج دالر و ينجاه كيلو كندم داده مى شود.

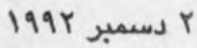

$\$ \&$

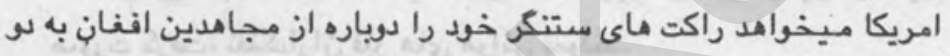

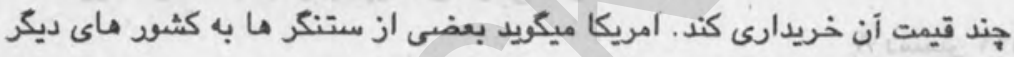
فرخته شده است. قيمت يك فير ستتكر از بيست و بنج تا سى و بنج هزار دالر الر است.

r

\& \& \&

در كابل جنك بين نيروهاى حزب وحدت و شوراى نظار دركرفته است، جنك در

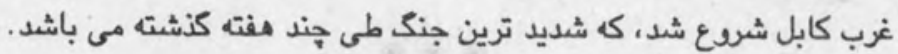

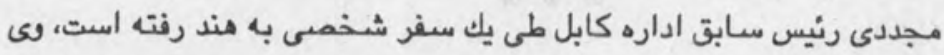

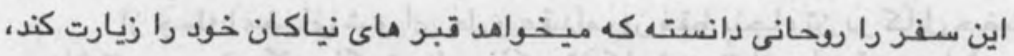
صدراعظم و وزير خارجه مند با وى ملاقات نمودند، حكومت هند بدين منظود تدابير

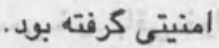

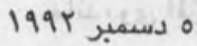

جنك براى رعذ سوم در كابل جريان دارد و امروذ در حسد يكمد و ينجاه نفر 
كشته و زخمى شدند تا اكنون مذاكره نيز صورت نكرفته است.

I دسمبر V9Y V

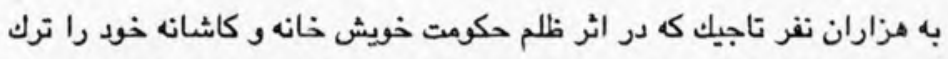

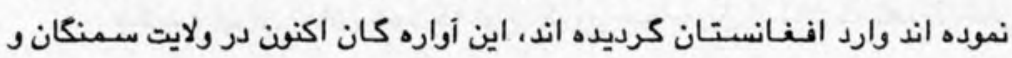
قندز بسر مى برند.

1997 دسمبر 199

\& 3

راديو كابل ساعت 1 شب اعلان نمد كه بين كروهاى دركير در كابل آتش بس صوت كرفت، تفنكاران فير ماي موانى نمودند.

A 1997

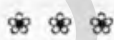

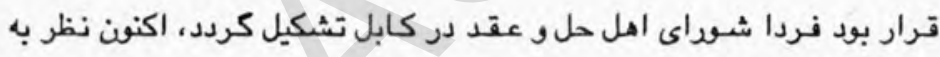

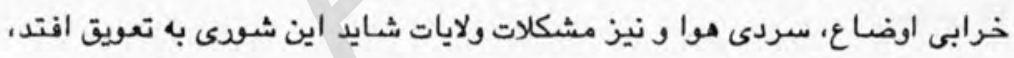

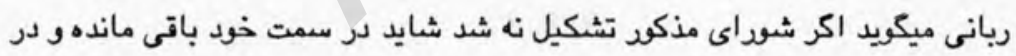

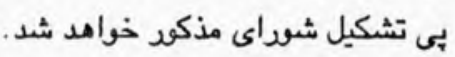

1994

(8)

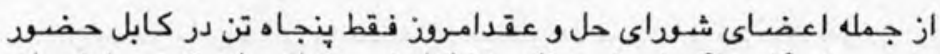

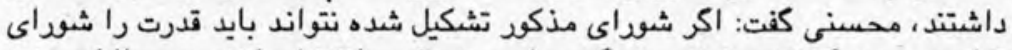

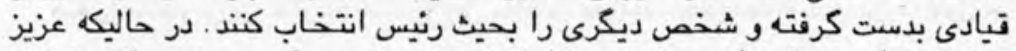

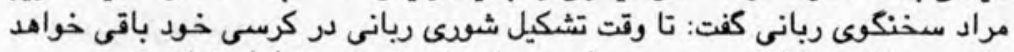
ماند، وعى افزود تا اخير دور دوم رياست ربانى اين شوري تشكيل خواهد شدر.

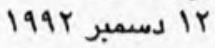




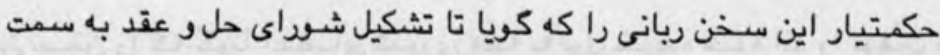
خود باقى خواهد ماند، اعلان جنك با مردم خواند.

1994 19 19

ربانى كفت: نمايندكان شوداى حل و عقد كه از ميان علماء و قوماندانان ولايات

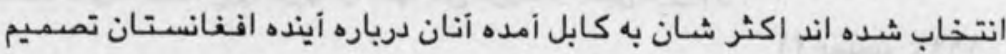

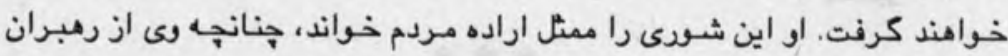

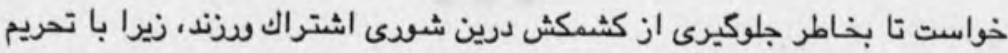

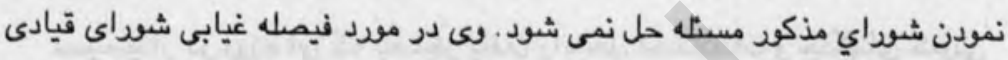

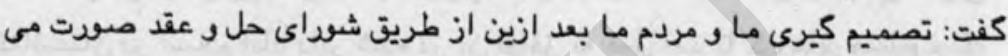

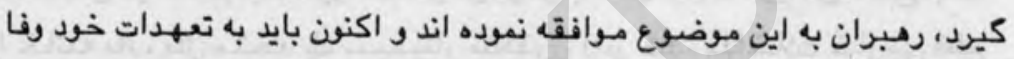
كنتد!

1997

$\$ \$$

اجلاس مقدماتى شوراى اهل حل و عقد در كابل شروع شد، نماينده تنظيم اتحاد اعضاى اين شورى را نمايندكان ملت خواند.

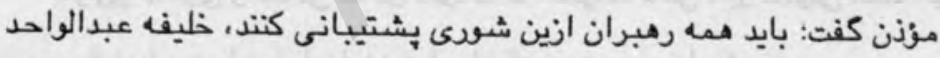

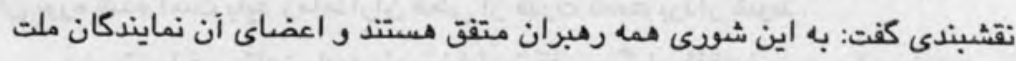

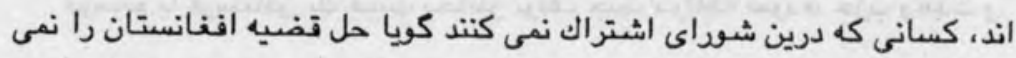
خواهند. 1997 19 19

در برخوديكه بين نيروماى دولتى و نيروهاى حزب در كابل رخ داد حد اقل ده نفر بقتل رسيد. عزيز مراد كفت: نمايندكان بانزده ولايت در كابل رسيده اند، وكى كانديد شدن

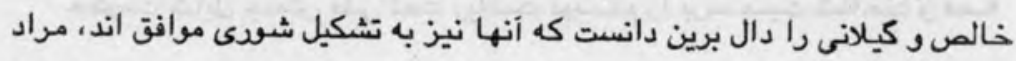




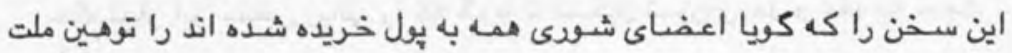
خوانده آن را رد نمود.

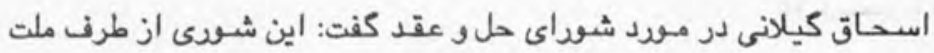

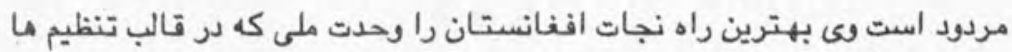

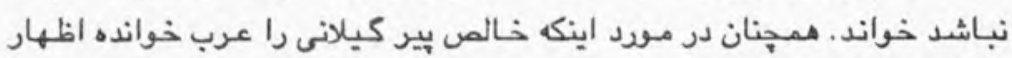
تأسف نموده كفت: بول عربها را أنها مى كيرند ما نمى كيريم و .....

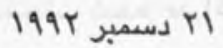

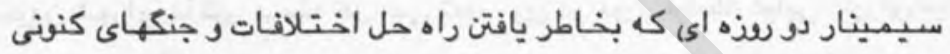

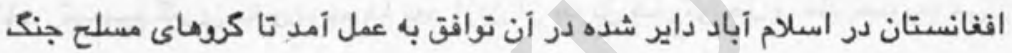

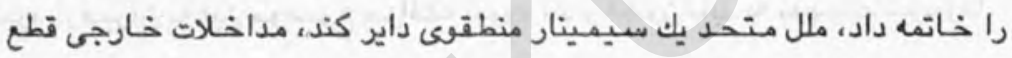

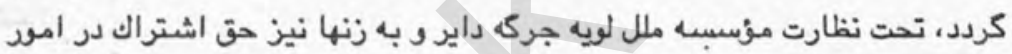
بولتى داده ثـود .

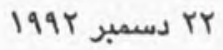

مولوى ذاكرى و حقانى اعلان نمودند كه حكومت فعلى غير قانونى است ميعاد أن يوده شده است بايد زمامداران فعلى از قدرت دست بردار شوند.

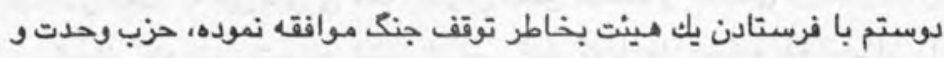
حزب اسلاهى نيز نماينده فرستاده اند، و نماينده دوستم نيز با أنها مى بيوندد، اين ابتكار از طرف حزب وحدت شده كه شامل آتش بس، تعويق انداختن شواى حل I99Y M Tr وعقد و تعيين سه نفر هينت از هر تنظيم منياشد.

$8 \& 8$

حكومت كابل جنبش ملى تحت رياست دوســم را برسـمـيت شناخت و ملــ 
خواست هاى آنان را تبول نمود كه از جمله اشتراك دوستم در شوراى قيادى نيز

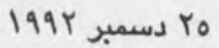

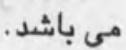

$\& \%$

سيد نور الله عماد طى مماحبه اي اعلان نمود كه از جمله اعضاى شوراىى اهل حلو عقد تا اكنون Irro نفر أن در كابل حاضر شده اند و عنقريب شورى داير خواهد كرديد. مراد كفت: در مورد برسميت شناختن جنبش ملى اطلاعى ندارد.

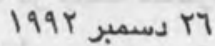

نماينده مؤسسه ملل در امود افغانستان أقاى موستويس در مورد انعقاد

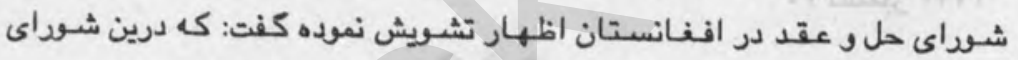

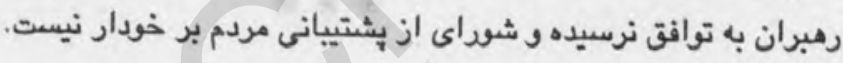

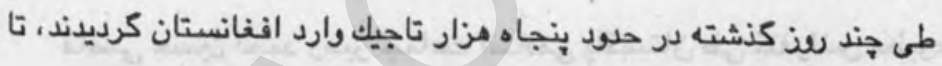

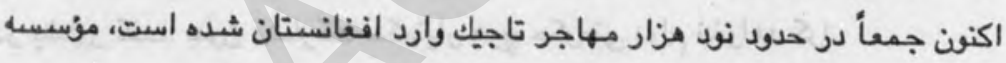

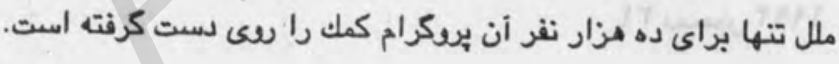
I T99 دسمبر TV

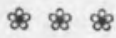

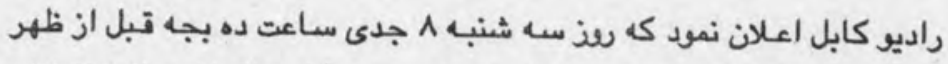

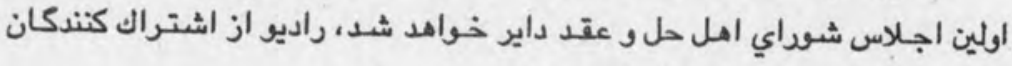
خواست تا بـ وقت معينه داخل تالار شوند.

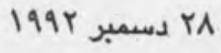

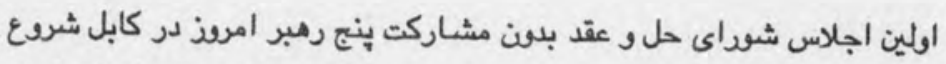

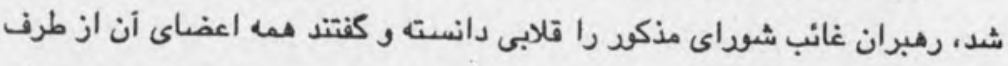

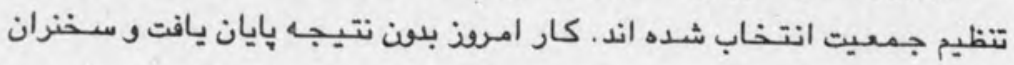


افتتاحيه بروكرام ربانى و سخنران دومى، سياف بودد.

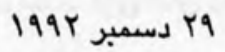

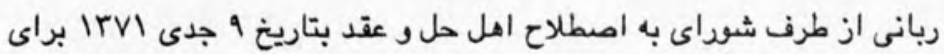

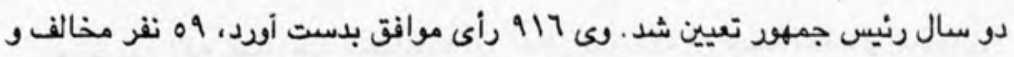

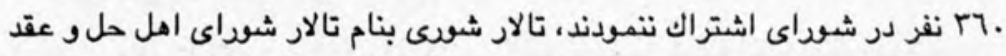

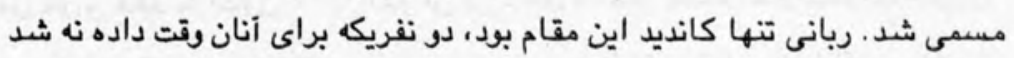

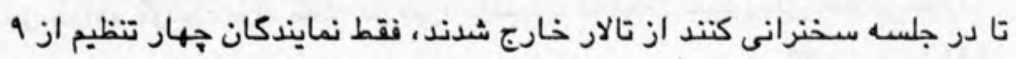

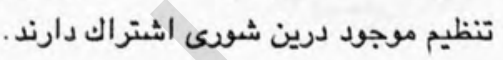

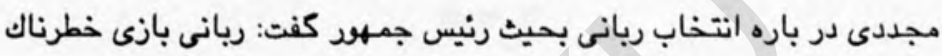
را شروع نموده است، حكمتيار انتخاب ربانى را اعلان جنك با ملت افنان ناميد.

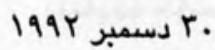

$\& \&$

تاضنى حسين احمد رمبر جماعت اسلامى باكستان طى كنفرانس مطبوعاتى در بشاور كفت: بدون مشاركت حكمتيار هيه حكومتى دوام نخواهد كرد.

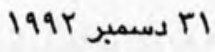




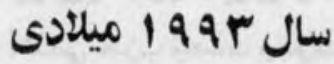

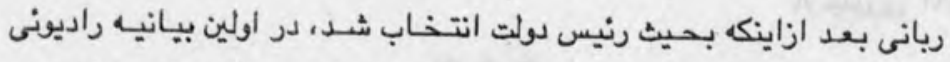

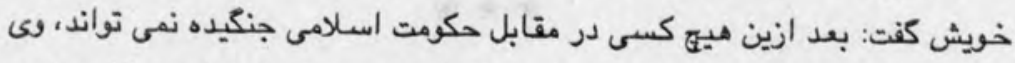

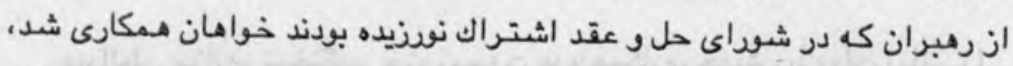

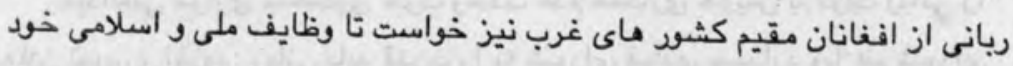

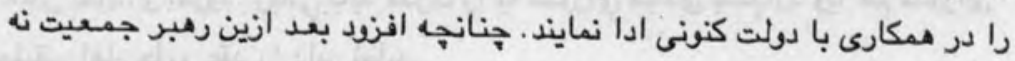

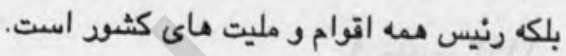

199r

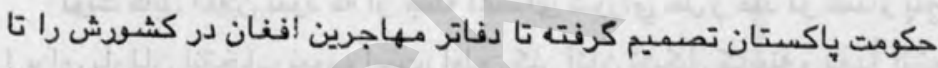

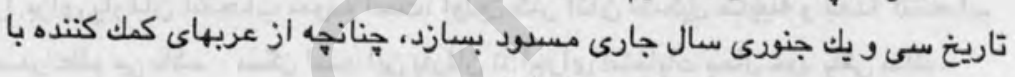

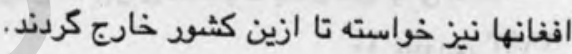

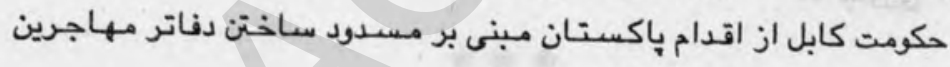

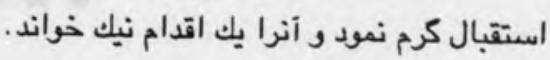

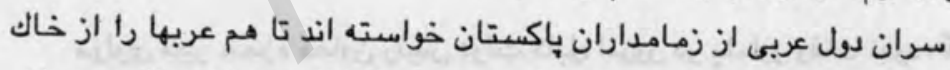

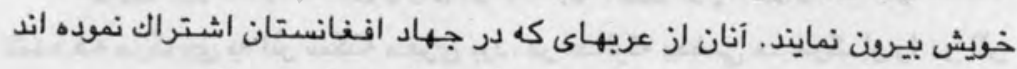
سخت در هراس بوده و ايشان را سبب بربادى مقام خويش مى دانتد. 199r

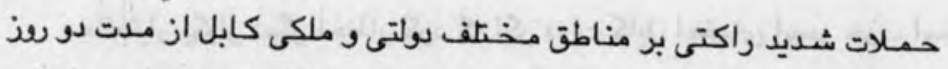

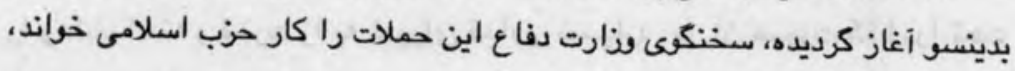

جنو V V

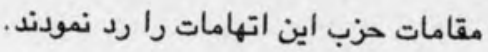


حوادث تاريخى افنانستان/ . 1.

عالوالدين برجردى معاون ونير خارجه ايران از مدت يك مفته بدين سو در

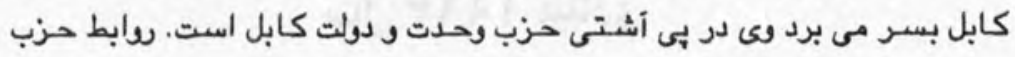
1

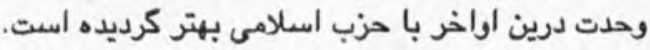

عبدالعلى مزارى سخنكوى حزب وحدت عدم همكارى خويش با دولت رباني را

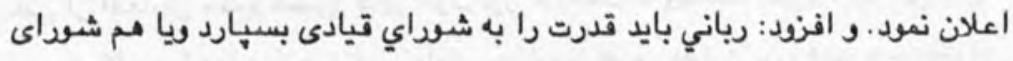
حقيقى اهل حل و عقد را داير نمايد. 9 جنويى 1994

بولت كابل اعلان نمود كه از جمله اعفناى شوراي حل و عقد بو صد و بنج نفر

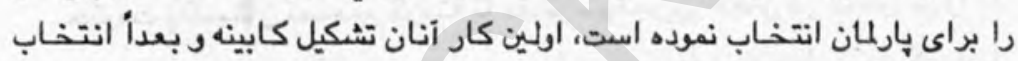

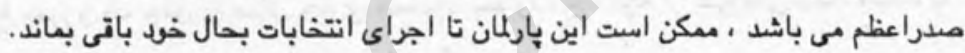

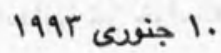

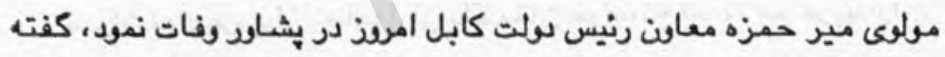

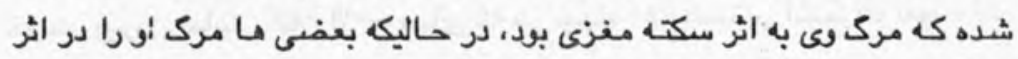

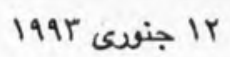
زخمى شدنش در جنكهاى اخير ميدانتد.

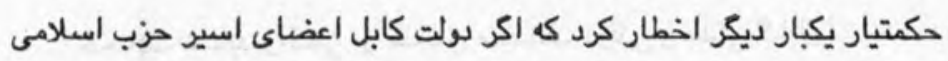

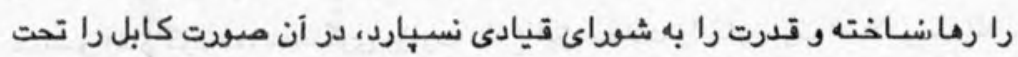
ضربات موشكى قرار خواهد داد. 199r Ir 


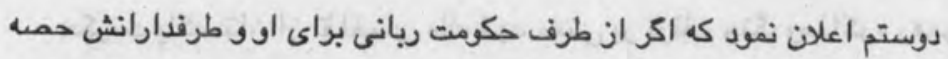

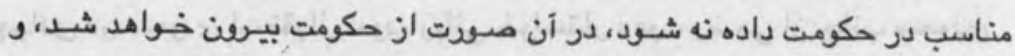

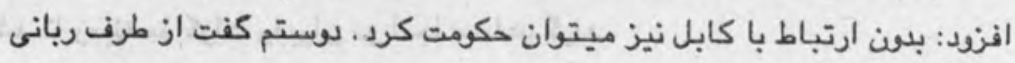

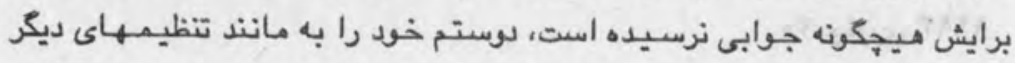

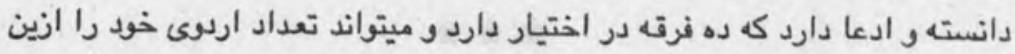

|

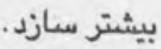

دولت كابل در شرق أن ولايت دست به يك سلسله عمليات تمفيوى زده استى

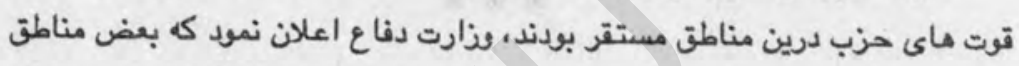

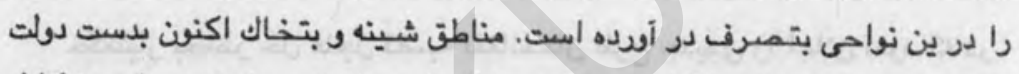

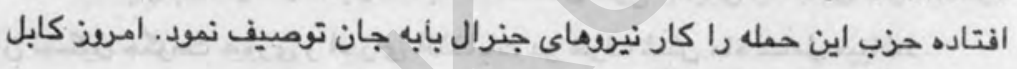
1994 sugu 19 تحت ضربات موشكى شديد قرار دارد.

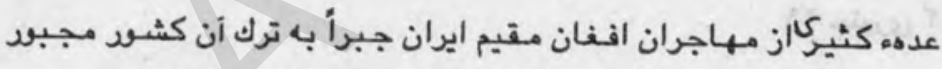

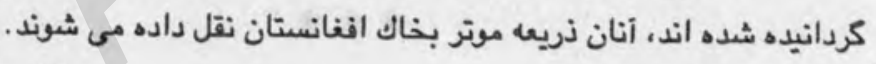

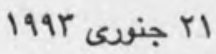

از مدت بنج عن بدين سو جنك شديد بين حزب اسلامى و بولت جريان دارد،

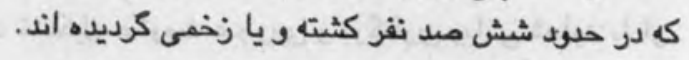

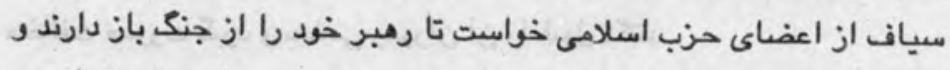

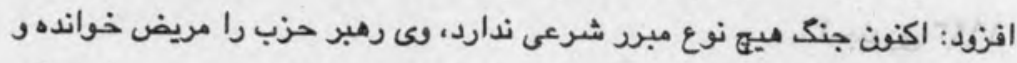

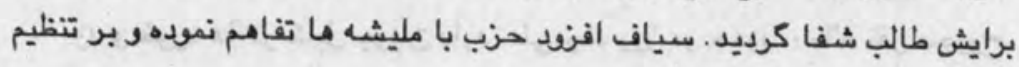

199r sur Tr

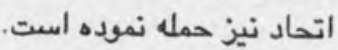


حكومت باكستان از تقاضاى ملك فهد مبنى بر توقف جنك ومذاكره رهبران

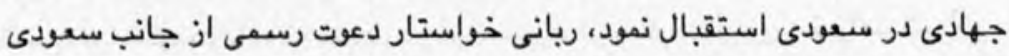
شد تا زمينه مذاكرات رهبران در أنجا مساءد كردد.

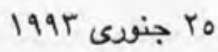

$\& \%$

جنك در كابل به شدت جريان دارد، ديلومات اخير خارجى سفير ايتاليا بود كه امرئ كابل را ترك نمود. در سفارت مذكود دو راكت امعابت نمود د.

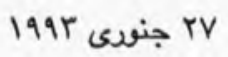

$\notin \circledast$

حكمتيار بخاطر حل عاجل تفضيه افغانستان طرح جديدى را اعلان نمود كه در

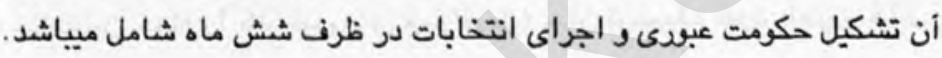

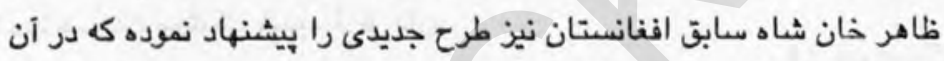

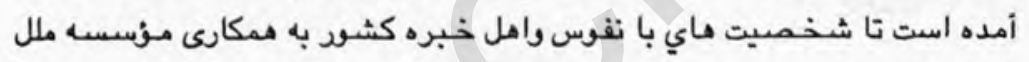
لويه جركه را داير و جرك، مذكود رنيس دولت را انتخاب نمايد.

1994 sug ra

$\$ \$$

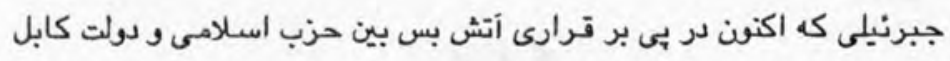

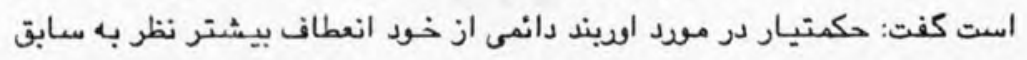

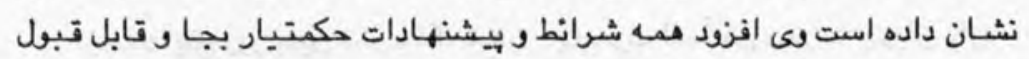

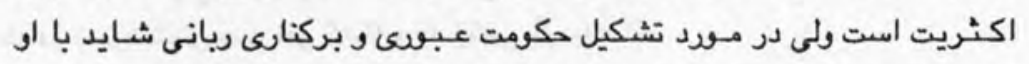
مخالفت صورت كيرد و بعضى رهبران أن را قبول نكئ نكتد.

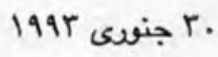

زد و خود ها در كابل جريان دارد، طى جند ريذ در حدود . .71 نفر مجروح

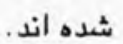

رهبران شش تنظيم به شمول نمايندكان حزب اسلامى و حزب وحدت در شهر 
جلال أباد تشكيل جلسه داده اند.

نماينده دولت درين جلسه اشتراك ندارد، دولت كابل كار تدوير شوراى قيادى التى

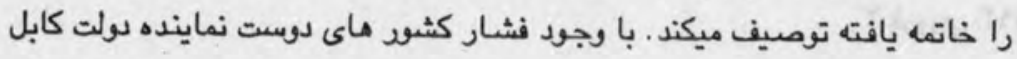

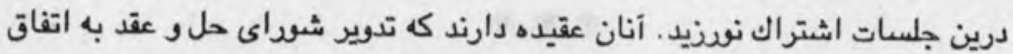

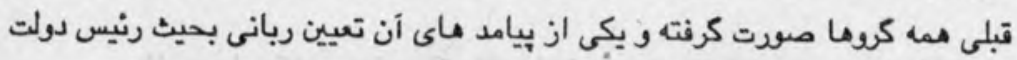

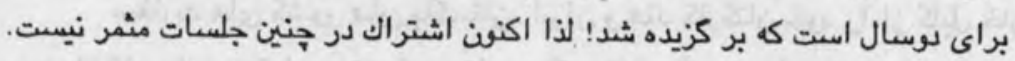

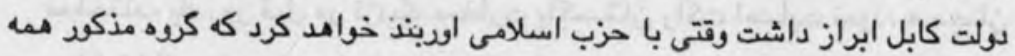
سلاحهاى ثقيل خود را به دولت كابل تسليم نمايد.

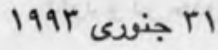

دولت كابل اعلان نمود كه عمليات تمفيوى را كه بر ضد حزب اسلاهى شرقع

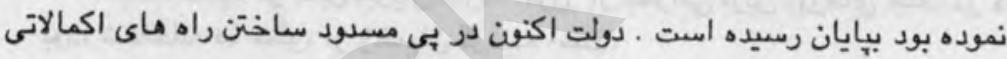
اين حزب است.

از طرف ديكر بولت كابل اعلان نمود كه جنرال دوستم نيز وعده همكارى با

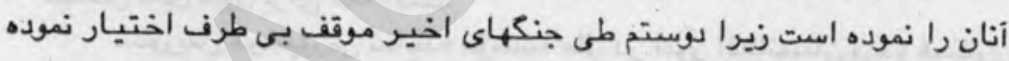
199r 19

نماينده دوستم در خشاور كفت: دوستم ميخواهد يك دفتر فرهنكى در بشاود.

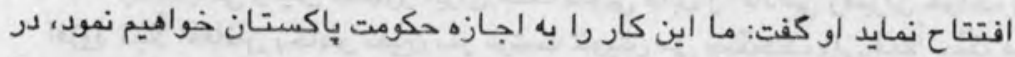

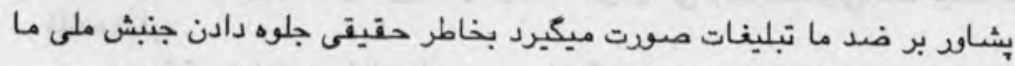

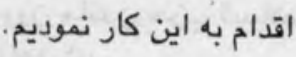

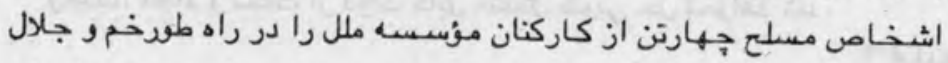

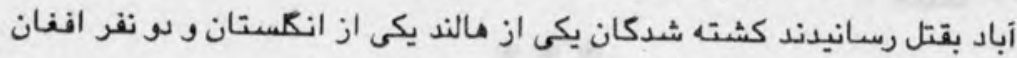
بودند.

امريز در حدود بيست نن در نزديك دفتر ملل متحد جمع شده بر ضد باكستان 
و ملل متحد شعار داده مى كفتتد: باكستان جرا بـ حكمتياراسله مي دهد و مؤسسه ملل جرا در حل مسنله افغانستان مداخله نمى كند.

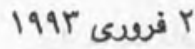

سفارت هأى كشود هاى باكستان، ايران و هند كاركنان خود را از كابل خارج

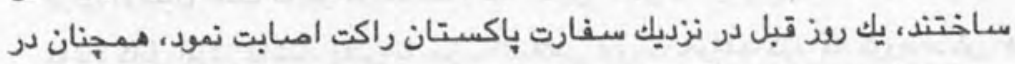

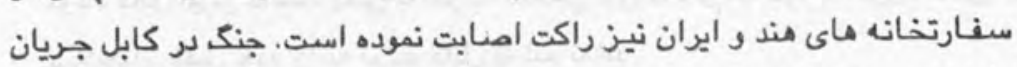

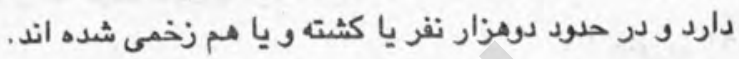

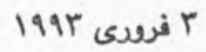

جنك شديد در كابل جريان دارد، امرنذ از بحرانى ترين سزهاى جنك در كابل

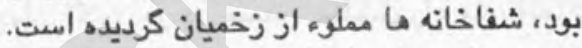

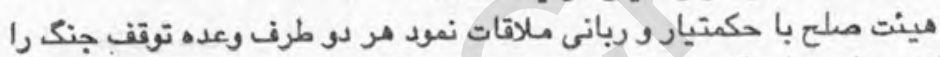

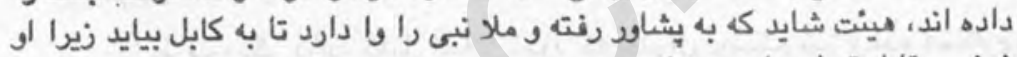

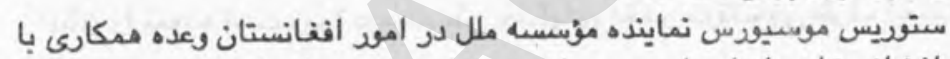

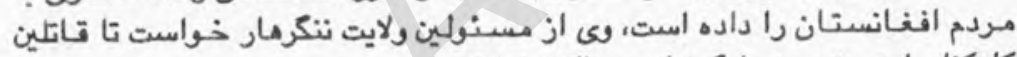

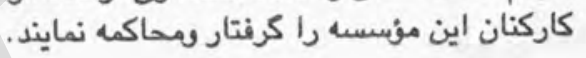
ع فري 1994

$\$ \&$

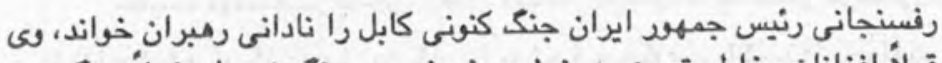

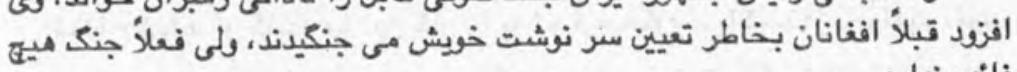

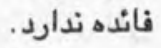

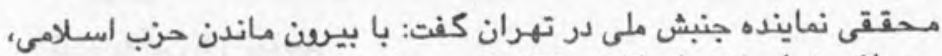

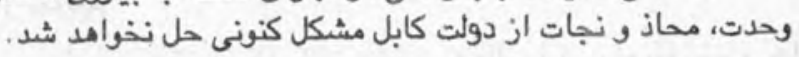

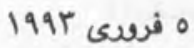


مزارى مركونه معاهده نظامى با حزب اسلامى مبنى بر سقوط دادن دولت كابل

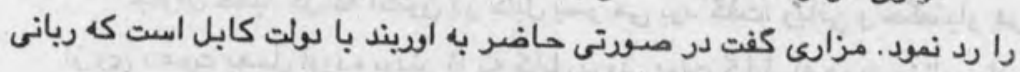
قدرت را! به شوراى قيادى بسيارد.

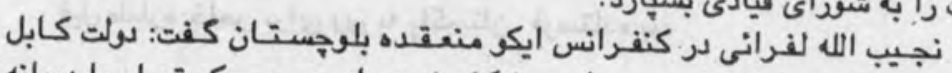

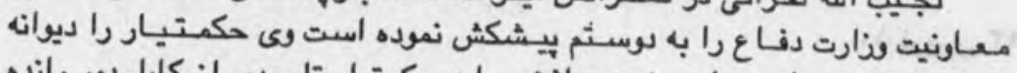

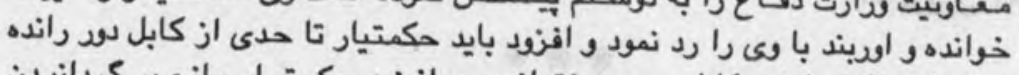

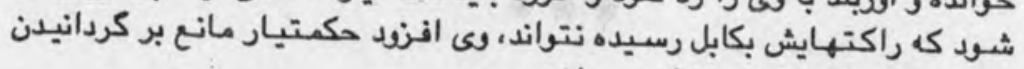
199r 7

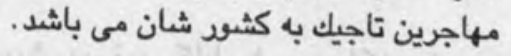

$\$ \&$

نماينده سوستم كفت: وستم وظيفه جديد در وذارت دفاع را تبول مى نمايد،

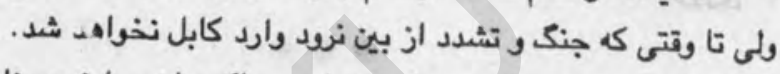

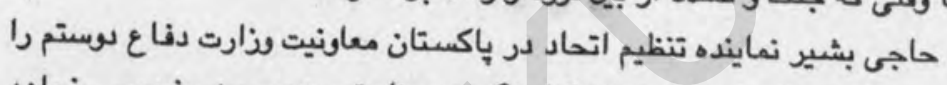

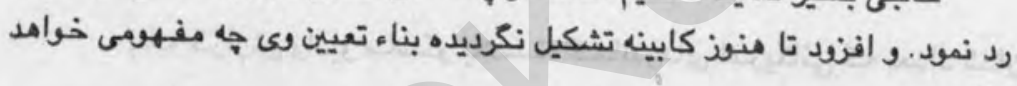
داشت.

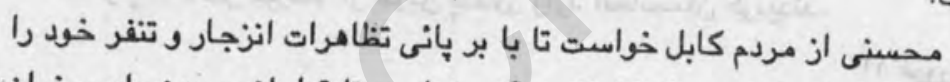

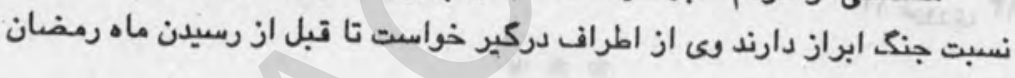
is V به توافق برسند. $\$ \&$

مولويى نمرالله منهود يكى از رهبران مجاهدين در بكيا در اثر ماين تعبيه شده در موترش بقتل رسيد.

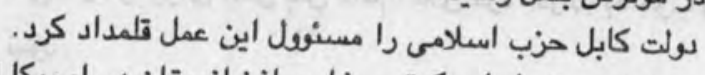

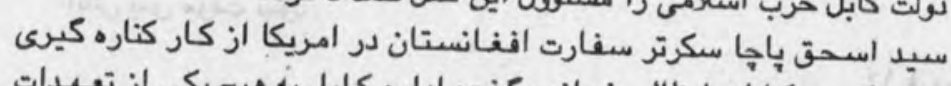

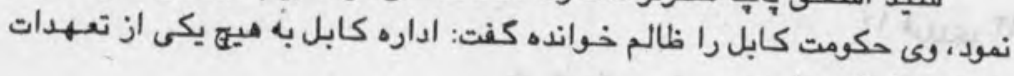
9 فريكى 991 خويش وفا نكرده است. 
جنرال حميد كل كه اكنون در كابل بسر مى برد كفت: ربانى و حكمتيار هر مو

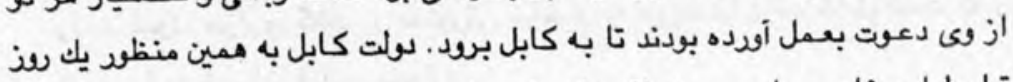

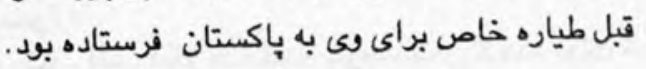

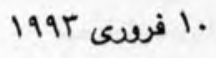

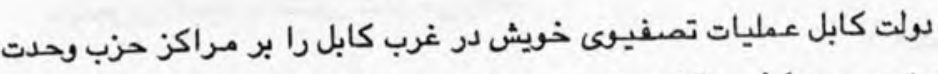

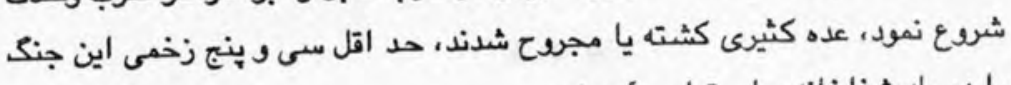

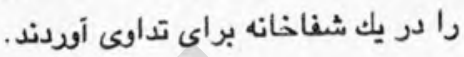

11

بنابه كزارش راديو مـاسكو يكسـته كماندوماى امريكانى كه تعداد شـان به هدو ينجاه نفر ميرسد از طريق بشاود وارد افغانستان كرديدند.

1994 (19

\section{\&8 \&}

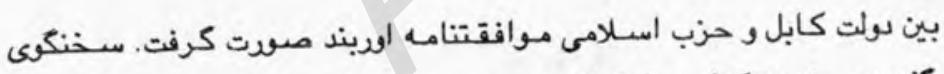

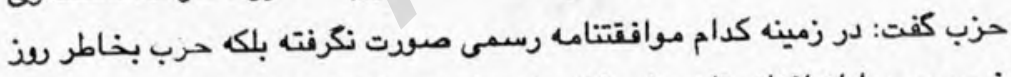

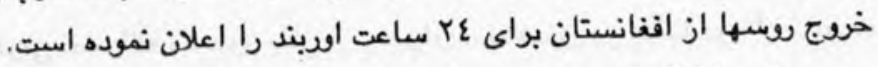

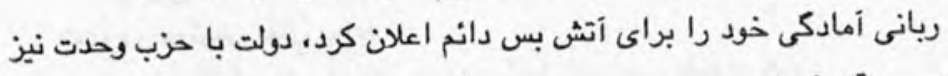
آتش بس موقت نمود.

ا فرون

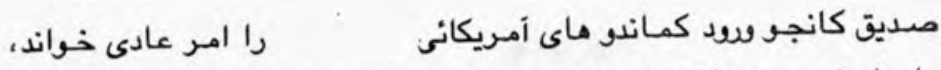

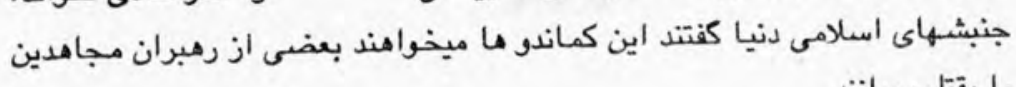
را بقتل رسانتد. 
تاضى حسين احمد نيز وارد كابل شد تا با رمبران مجاهدين ملاقات نمايد.

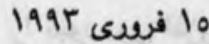

حكمتيار كفت: ما ديرن اوربند يكطرنه را اعلان نموديم، و بعد از ين تا وقتى

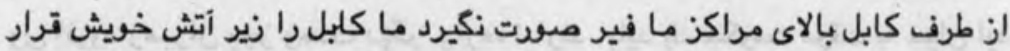
تخواهيم داد. حكمتيار كفت: ما شرانطى براى صلح دارئ داريم كه شامل سبيردن تدرت

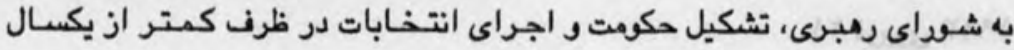

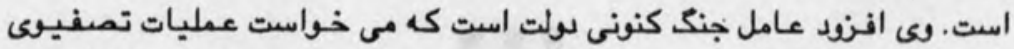

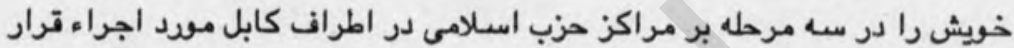

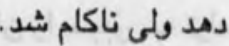

1994 فرئ17

$\$ \& \&$

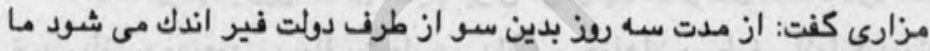

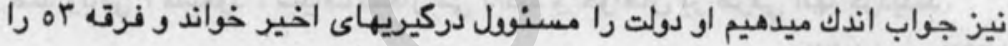

1994 فرسكى قوه بيطرف ناميد.

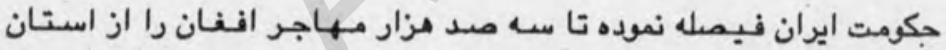
خراسان به داخل افغانستان بفرستد.

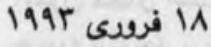

$8 \% 8$

غلام محمد آرين بود والى بدخشان ، سيف الرحمن سايف همراه با صوفى

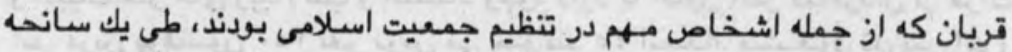
هوانى (تمبادم ميليكويتر با كوه) به قتل رسيدند.

19 فرسى 1994 


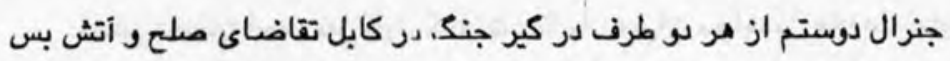
را نمود، وى افنزد بايد به كشور ماى بيكانه حق مداخلت در امور داخلى درئ افغانستان داده نشود.

قاضى حسين كفت: ما با خود طرح خاصى براى حل تضيه افنانستان از

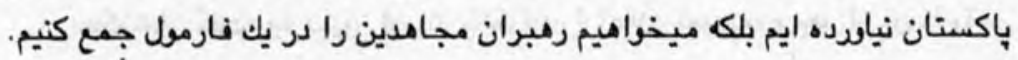

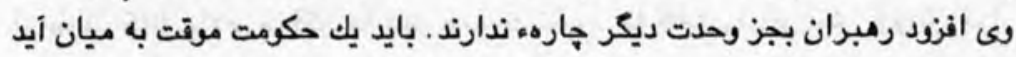

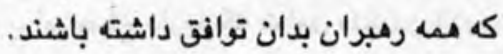

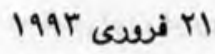

محقى نماينده دوستم بر حكومت ايران انتقاد كرد كه افغانان را مجبود به ترك

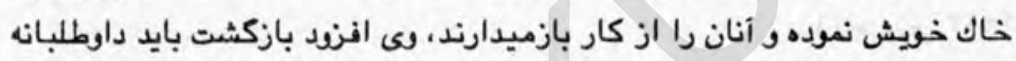

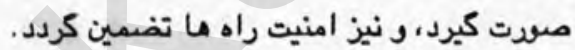

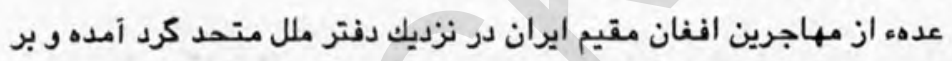

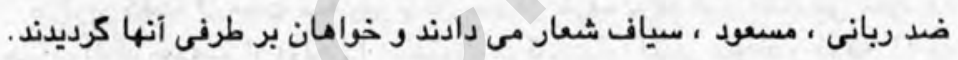

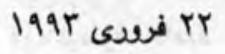

داكتر فضل احمد ابراهيمى رئيس بوهنتون ننكرهار كفت: بوهنتون نتكرهار

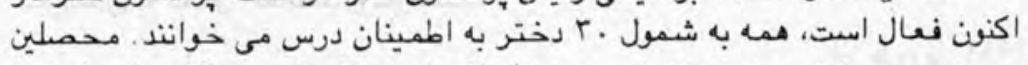

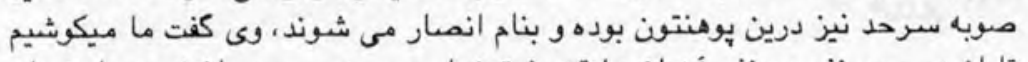

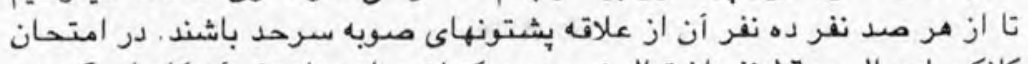

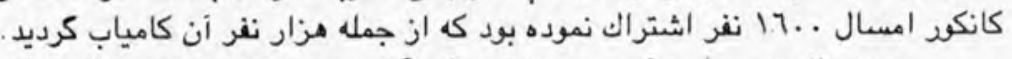

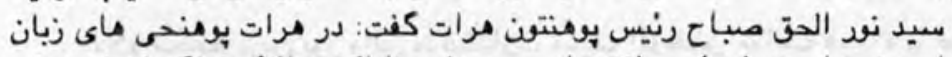

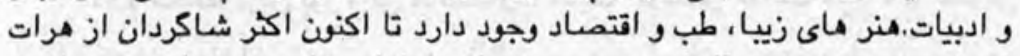

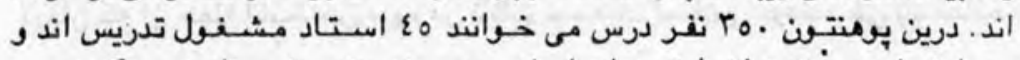

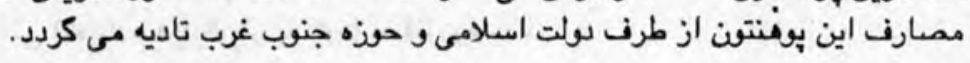

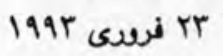


هفته كنشته دوستم وارد باكستان شده و با صدراعظم و وذير خارجه باكستان ملاقات نموده بود.

طى جند رذ وضع كابل خوب بود، در حدود سه صد تن از فاميلهاى شهبداء در دمن درازه رياست جمهودى مظاهره نموده خواستار حقوق خود كرديدند.

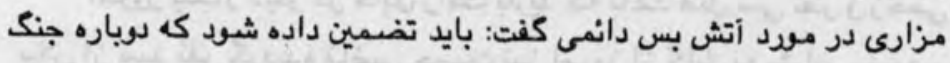

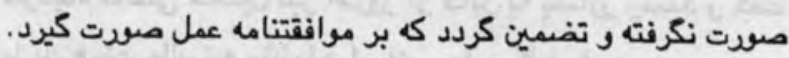

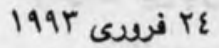

حكومت باكستان از رمبران مجاهدين درخواست نمود تا به اسلام أباد أمده و

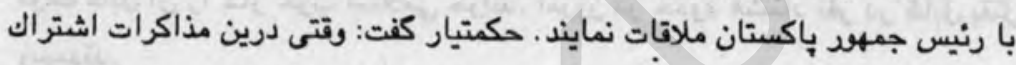

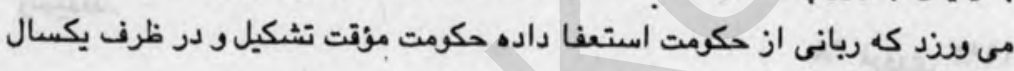
انتخابات صورت كيرد.

199r Tre

بولت و حزب اسلامى يكبار ديكر مراكز همديكر را مودد ضربات شديد اسله 199ז 199 سنكين قرار دادند.

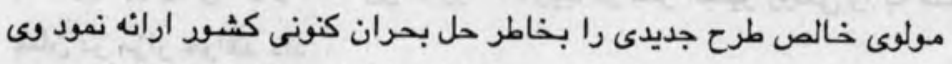

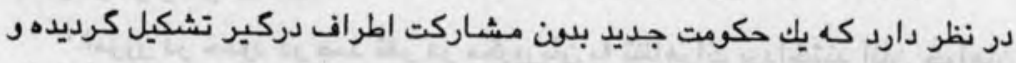

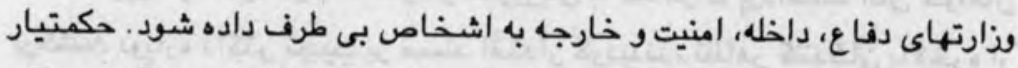

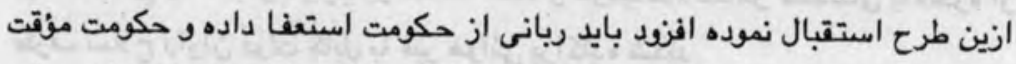

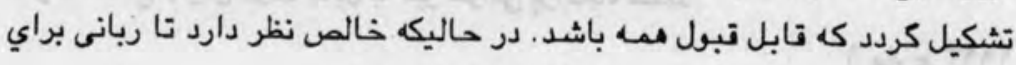
دوسال درين سمت باقى ماند صرف كابينه اش تغيير يابد.

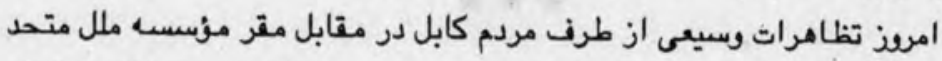

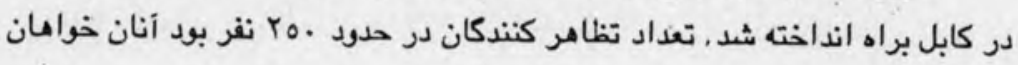


حقق خويش بودند كه براي شان معاش كوين و ... داده شود.

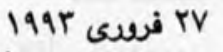

امروذ يكبار ديكر در كابل راكت باريد كه باعث تتل سى نفر و زخمى شبدن

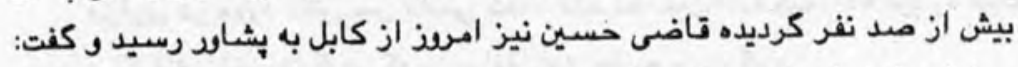

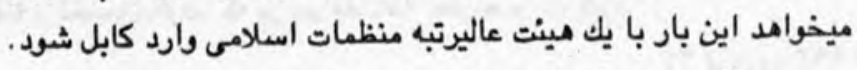

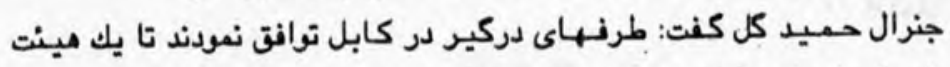

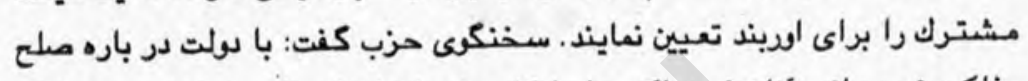

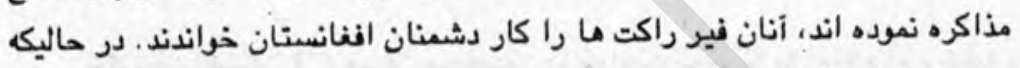

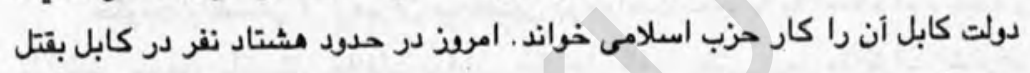
برسيند.

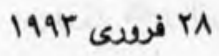

$\$ \& 8$

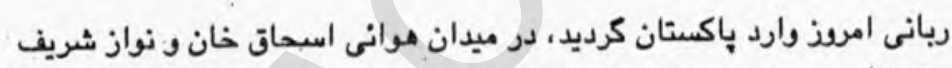

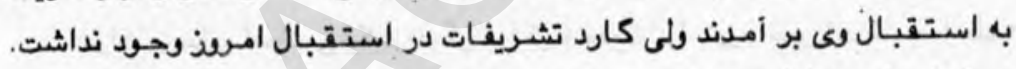

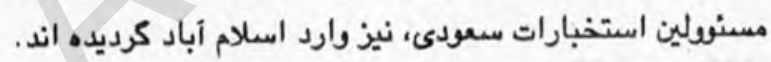

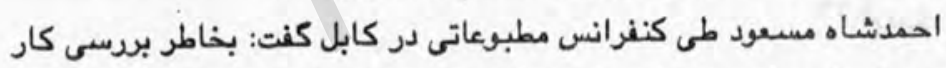

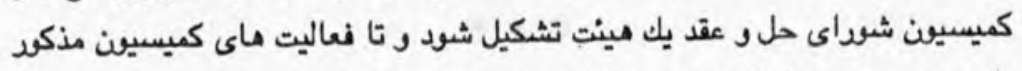

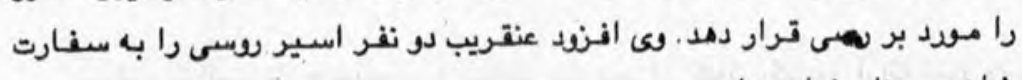
شان در مزار خواهد داد.

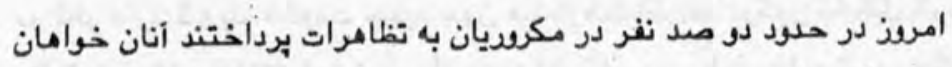

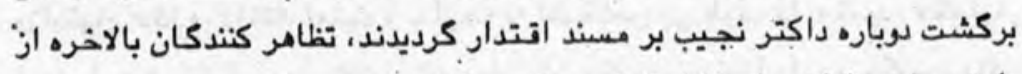

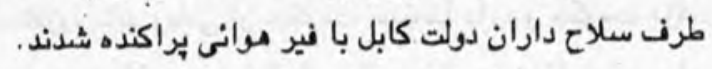
1994 


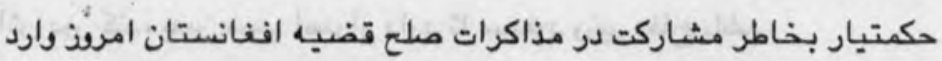

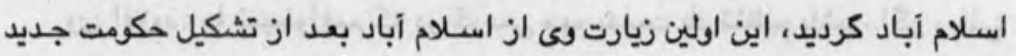
در كابل است.

فيمل التركى وذير امنيت سـعودى و بروجردى بنماينده ايران نيز بخـاطر

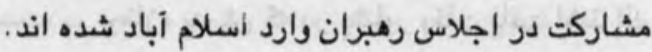

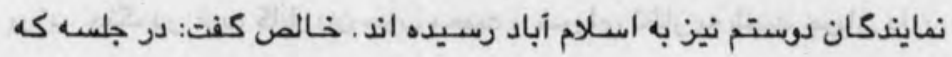

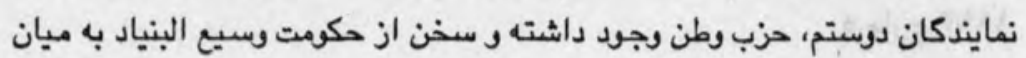
أيد اشتراك نخوانداند دوسند حزبد

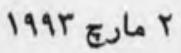

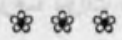

ربانى و حكمتيار با هم ملاقات نمودند. نماينده حزب وحدت كفت: در سابق

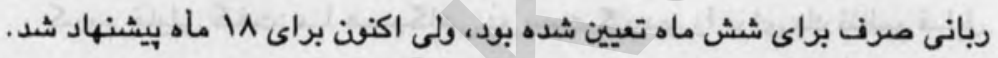

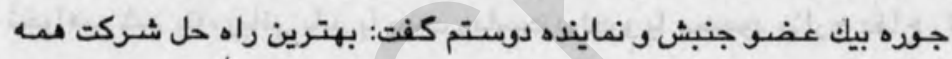

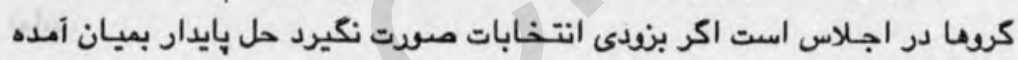
نمى تواند. حكمتيار به برجردى كفت: هر زعيمى كه مودد تبول همه باشد او را تبول خواهد كرد ـ رى نقش ايران در امو افغانستان ردا تعيين كنتده خواند. $199 r$ r مار

$8 \& 8$

رهبران مجاهدين اكنون در منزل نواز شريف بسر مى برند . دى در بى كرفتن

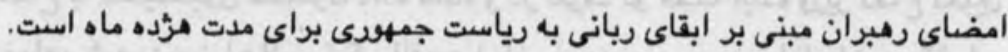

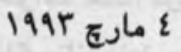

حكتيار در يك اجتماع منعقده نصرت مينه بشاور كفت: تا اكنف با ربانى در

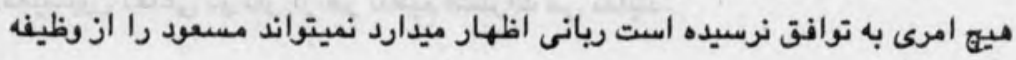


اش در كند، بدين سبب اصرار دارد تا مسعود وزير دفاع باشد.

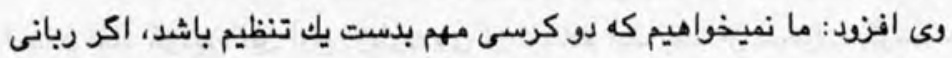

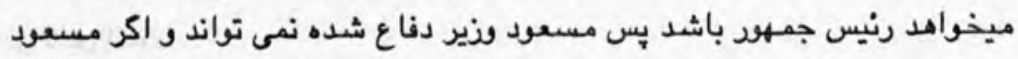

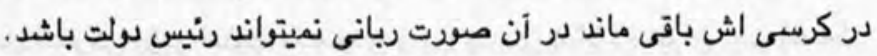

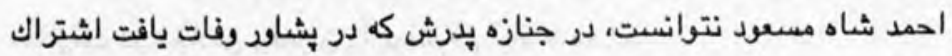

رذد . جنك در غرب كابل بين حزب وحدت ر شوراى نظار به شدت جريان دارد.

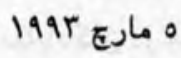

$\& \& \$$

امرئ دو نفر اسير رسسى از طرف بولت كابل رما كرديد آنها اين كار خود را

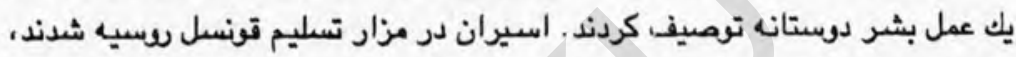
لى كفت هشتاد اسير بوسى نزد مجاهدين باقى است.

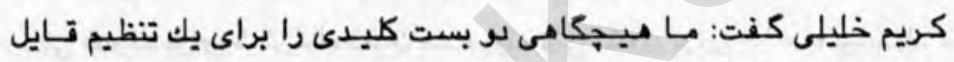
نخواهيم شد بناء ربانى بايد يا بست رياست دولت و يا مسعود رذارت دفاع را ترك برك نمايد. 1994 19

رمبران مجاهدين به شمول ربانى و حكمتيار موافقتنامه صلح را در اسلام آباد

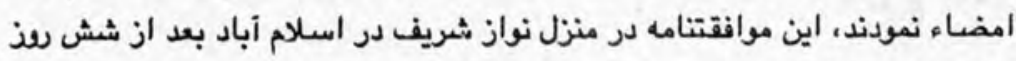
مذاكره به امضاء رسيد. ربانى براى هزده مـاه در مقامش خراهد مـاند، حكمتيار مسدراعظم ودذارت

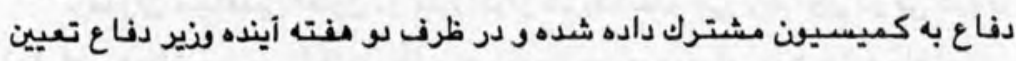

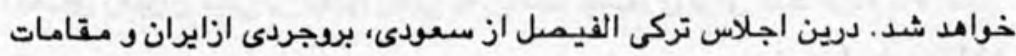
باكستانى نيز حضور داشتند. از طرف ديكر احمـشـاه مسـعود در كابل كفت: تا اكنون در باره كذاشتن

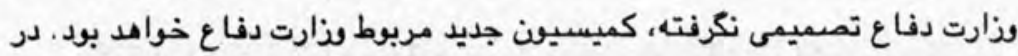
كميسيون دفاعى دو نفر از هر تتظيم اشتراك مى نمايند. 


$$
\text { اين نهمين قرار داد صلح بين حزب و جمعيت است. }
$$

1991 مارع

\&ै \& 8

رهبران مجـاهدين همراه با نواز شريف وعده اى از ونداى باكسـانى عازم سعودى شدند و با ملك فهد ملاقات نمودند.

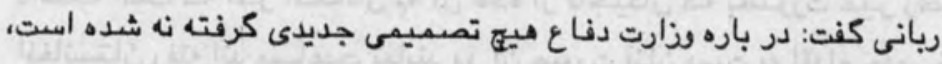

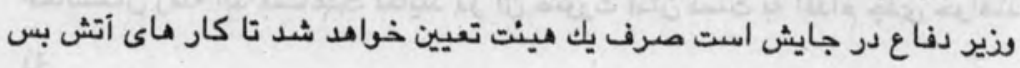
را بردسى كند.

مولوى خالص كفت: از ييمان اسلام آباد بوى خون مى آيد، ولى از كار هاى

1991 مارع اسلامى أن بشتيبانى مى كند.

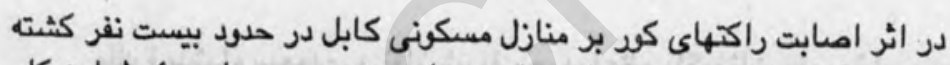

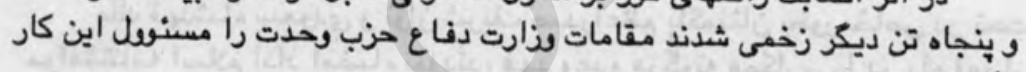
دانستند. مقامات سعودى موافقتنامه اسلام أباد را يك كام نهايت اهم و مفيد خواندنره

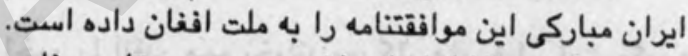

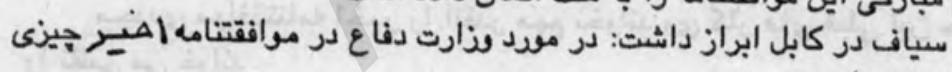
1994 مارع كفته نه شده است. $\& \&$

طى لو ماه اخير در حدود هردّه هزار نفر از افغانستان به بشاود أمده اند.

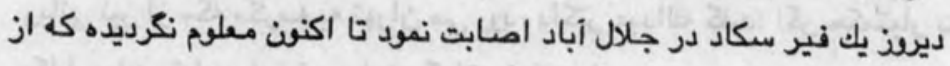
1991 (199 مارع

$$
\text { كدام سو فير شده بود. }
$$


احمد شاه مسعود طى مماحبه اي ابراز داشت: در صورت موافقه رمبران از

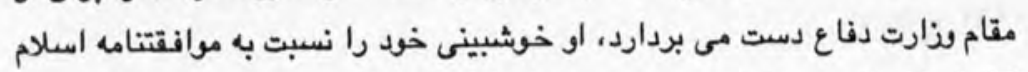

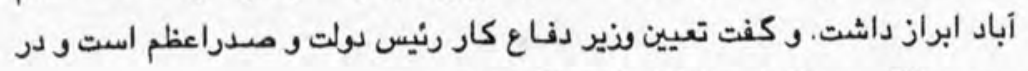

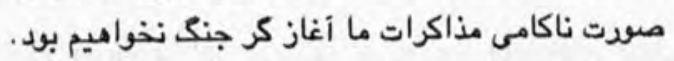

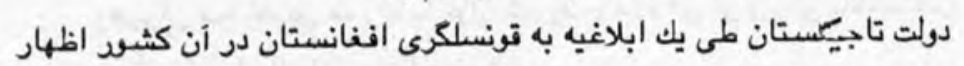

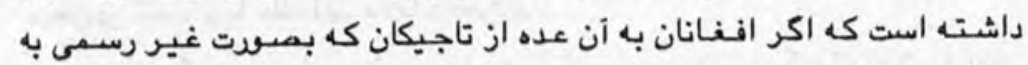

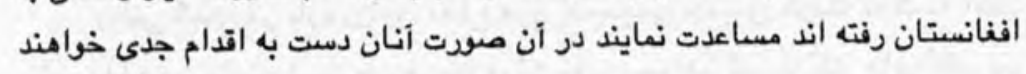

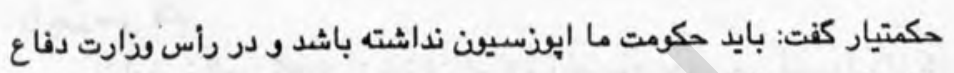
كسى باشد كه در جنكهاى اخير اشتراك نكرده باشد تا همه قوماندانان اسلحه ثقيله خود را به دذارت دفاع بسيارند.

1994

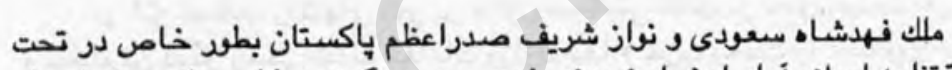

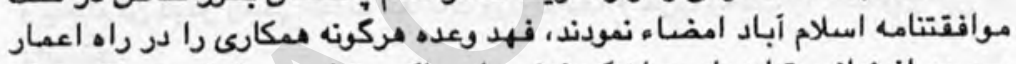

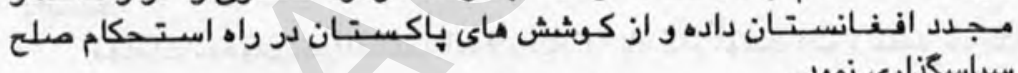
مجددى موافقتنامه اخير را آنقدر مهر نخواند بى كار ماى قبلى اين حكومت را تقلبى مى خواند. 1994 إ مارع

$\$ \& \&$

نواز شريف وحكمتيار بخاطر ملاقات با رنيس جمهرد ايران به تهران رفتتد،

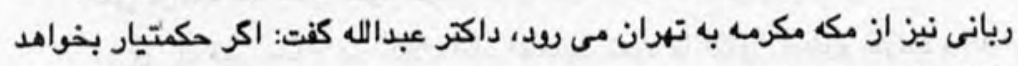

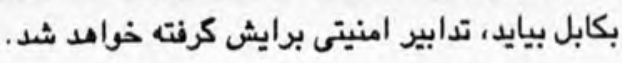

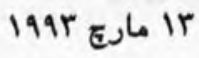


نطاق نيروى ها شمال اعلان نمود كه موافقتنامه اخير رهبران در اسلام آباد

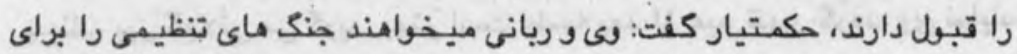
هميش از ميان بردارند.

1994 E 18

امرئ ربانى از تهران به كابل رفت. ربانى كفت: اكر مسعود ونير دفاع نباشد.

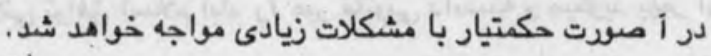
حكمتيار از رهبران جهادى خواست تا بخاطر تشكيل كابينه وارد جلال آباد

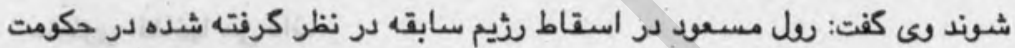

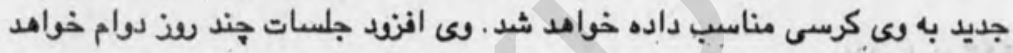

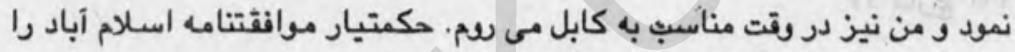
جدا از شواى حل و عقد دانست. سياف و خالص مخالفت شديد خوب را در مقابل جابجا شدن قواى صلح در افغانستان ابراز داشتتد و آن را ازدياد اختلافات معرفى نمودند.

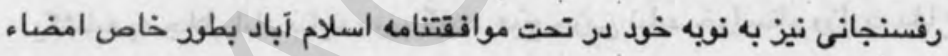

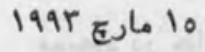

تا اكنون حكمتيار، مجددى و نماينده حزب وحدت در جلال آباد رسيده اند،

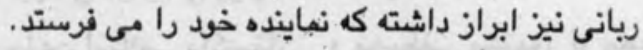

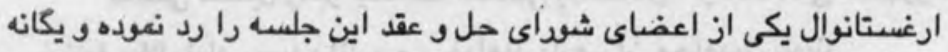
راه رسيدن به ملح برا تشكيل لويب جركه عنعنوى افغانان دانست.

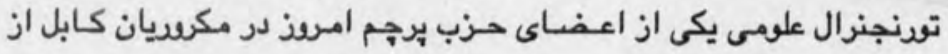
1994 ש 19 طرف اشخاص مجهول بقتل رسيد. 
سخنكوي ربانى كفت: بايد حكمتيار و ربانى قبل از اجلاس جلال أباد با هم ببيند. يير كيلانى مى كويد: بهتر است جلسه بعد از عيد تدوير كردد . وكى نماينده

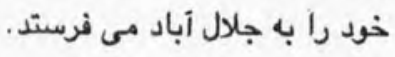

شـواى تفاهم كه از هندى بدين سـو در بشـاور تشكيل شـده مس كويد : بايد

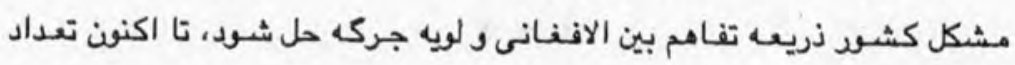

$$
\text { شواى تفاهم به صد نفر مى رسد. }
$$

سيد اسحاق كيلانى توافق اسلام آباد را غير قانونى دانسته و ميكويد بهتر آن بود تا اين كار در داخل افغانستان صودت مى كرفت. او يكانه راه حل را لويه جركه عiعنوى افغانها مى داند.

199r IV مارع

\section{\&8}

حكمتيار از رهبران مجاهدين خراست تا بخاطر تعيين كابينه جديد الى شذ يكثنبه به جلال آباد بيايند، وكى كفت: هيه حزبى نبايد خواستار وذارت دفاع كردد. نماينده اتحـاد در اجلاس جلال آباد انجنير احمد شاه مى كويد: بهتر ميداند تا

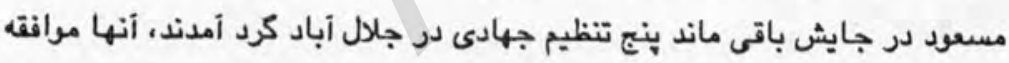
نمودند تا به هر تنظيم بزرك جهادى بركرسى وذارت داده شود .

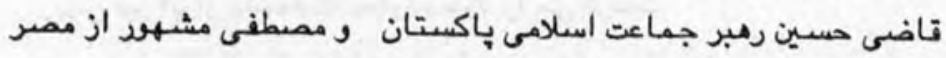
نيز به جلال آباد رسيده اند و مى خواهند بارهبران مجاهدين بينتد.

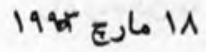

رهبران و نمايندكان منظمات جهادى در شهر جلال آباد حاضر شدنمذاكرات در مودد تعيين وذير دفاع نيز شردع شده است. بيشنهاد شده كه به هر تنظيم بو وذارت داده شود و هر تنظيم براى يك دذارت ينج نفر را هعرفى كند و در باره اينكه به جمعيت رياست جمهردى و يا وذارت دفاع مرهاع 
داده شود بحث جريان دارد، نماينده خالص در مذاكرات مذكور اشتراك نونيده است.

1994 E 19

$8 \& 8$

در مذاكرات جلال آباد ييشرفت صودت كرفته، رمبران مجاهدين موافقه نموند

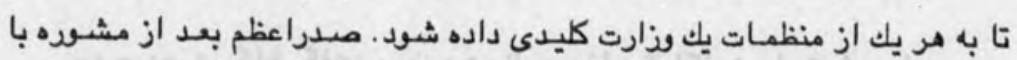

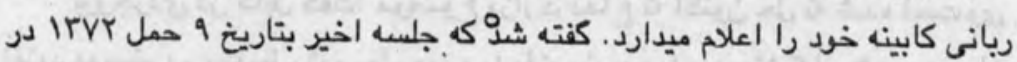

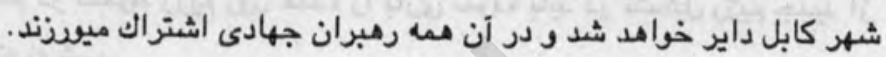

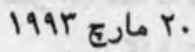

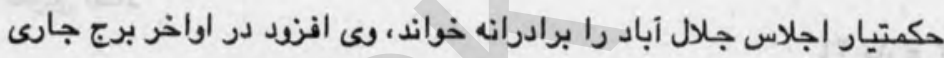

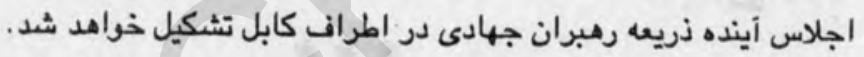

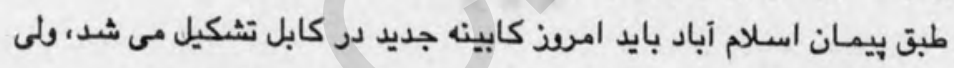
بحث رعى موضوع وذارت دفاع تا اكنون به نتيجه نهانى نرسيده است.

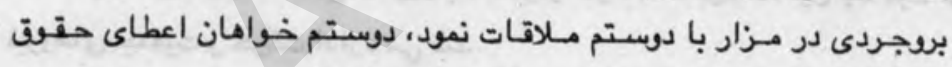

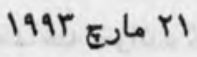

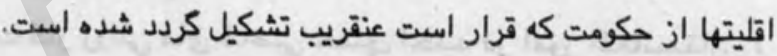
\& \& \&

حميد كل جنرال متقاعد باكستان از اطراف دركير قضيه افغانستان خواست تا نوتر كابينه را تشكيل داده و حكمقت جديد خود را اعلان نمايند.

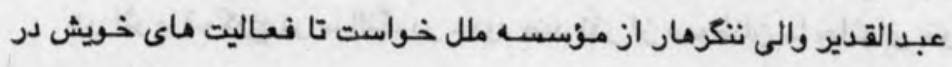

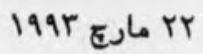
شهر جلال آباد را آغاز كثد.

ربانى طى ممساحبه اي كفت: حكمتيار از ين اصرار خود كه كويا مسعود وزير 
دفاع نباشد بايد دست بردارد،بكى افزود اين كرسنى به مسعود داده شود او اين امر

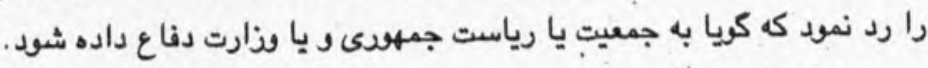

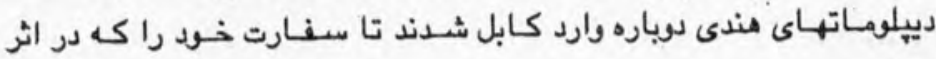

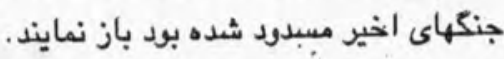

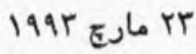

بروجردى در كابل كفت: موضوع حذارت دفاع تا اكنون حل نه شبده است رىى

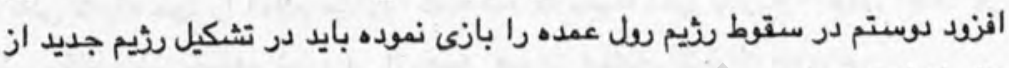
نظر انداخته نه شود. رذ كذشته ربانى وقتى مودد حمله ترار كرفت كه ميخونست با حمتيار در

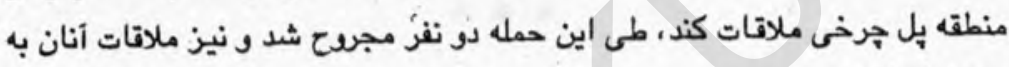
تعويق افتاد.

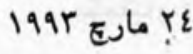

نيرهاى حزب اسلامى كتترل بند نغلو را در دست كرفتتد، اين بند قبلأ توسط

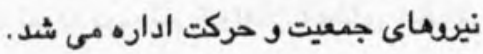

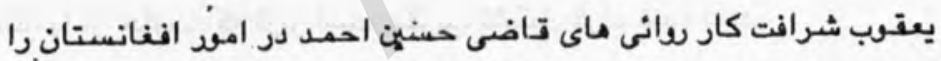

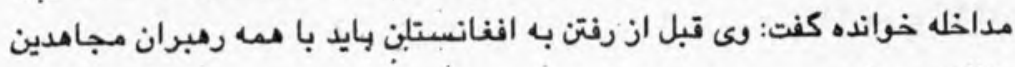

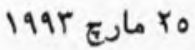

در اثر برف كوع در سـالنك در حدود صد نفر از هموطنان ما جانهاى خود را

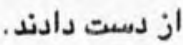

199r 
سياف بخاطر جلسه رمبران جهادى كفت: بايد رنيس جمهرد جايى جلسه را تعيين كند تا همه رمبران حاضر شوند و ى افزود بايد مسعود در وذارت دفاع باقى رئى

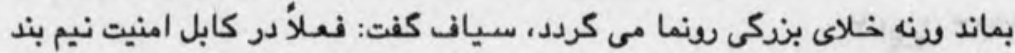

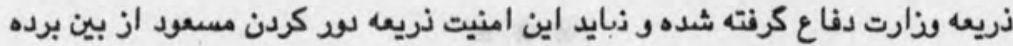

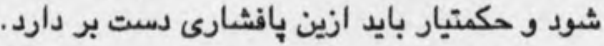

199T مار TV

कृ

عزيز مراد سخنكوى رياست جمهودى كفت: ميجكونه لستى را در باره كابينه

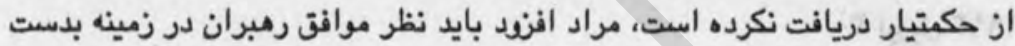

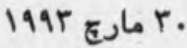

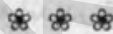

امرن اعلان كرديد كه فردا نمايندكان مشت تنظيم در جهار آسياب جمع شده و كابينه جديد اعلان مى كردد. مذاكرات بين ربانى و قاضى وقاد و نيز حكمتيار ور سيد نورالله عماد جريان دارد.

199r 199 مارع

\&

حكمتيار با سفراى باكستان و ايران و نيز با جنرال مثقاعد حميب كل مالاقات

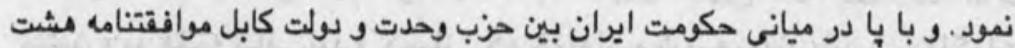

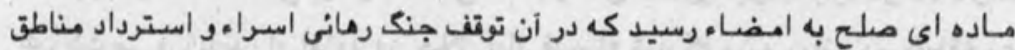

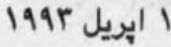
يكديكر شامل است.

صدراعظم حكمتيار در جهار آسياب طى كنفرانس مطبوعاى ابراز داشت: لست كابينه جديد را به ربانى فرستاده است و در يكى دو رعذ آينده كابينه جديد

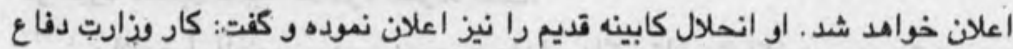


را شوراى تنظيمهاى جهادى بدست خوامند كرفت و امكان دارد كه رياست شورى بدست مسعود باشد. تا اكنون ربانى در مورد هيزى نكفته است. برديت

ايريل ra9

سياف طى كنفرانس مطبوعاتى در كابل كفت: در زمينه كابينه جديد با وى هيجكونه مشوره صروت نكرفته است.

ربانى طى بيانيه اي كفت: تا اعلان كابينه جديد ونداى سابق كار هائ خود را به بيش مى برند. از طرف ديكر سياف افنود حكمتيار حق انحلال كابينه را ندارد.

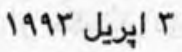

صادق بروانى و محسنى كفته اند در تشكيل كابينه حكمتيار با آنان مشروه

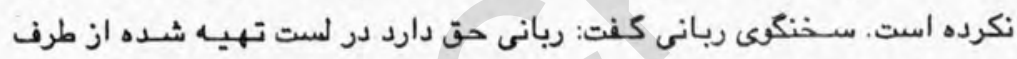
صدراعظم تعديلاتى بميان آودد ودر حجم كابينه واقعيتها مدنظر كرفته شود د. ع إيريل 1997

\section{$\$ \$ 8$}

حكمتيار طى مصاحبهء مطبوعاتى در جهار آسياب كفت: رمبرانمدر مودد

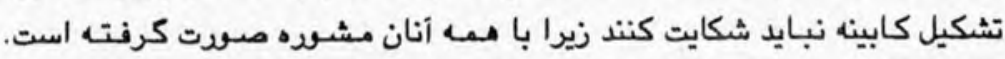

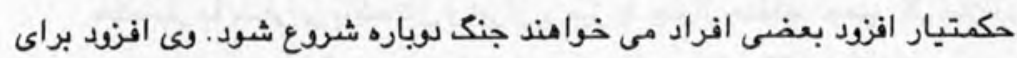

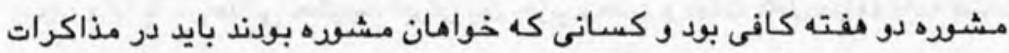

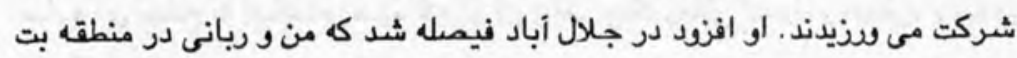
خاك با هم ببينيم ولى ربانى نتوانست أنجا بيايد.

1 1994 ايريل

مديق الله قوماندان حركت در ده سبز بنقل از ملا نبى كفت: حكمتيار با بى در مود تشكيل كابينه مذاكره نتموده است

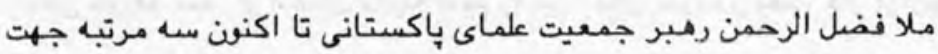


بافتن راه حل قضيب به داخل افغانستان رفته است وى كفت در جند روذ آينده بين

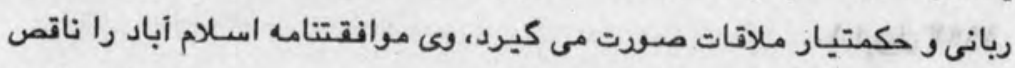

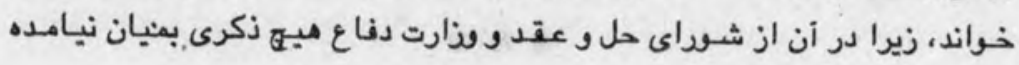

17 ايريل 1997

است.

$\nLeftarrow \%$

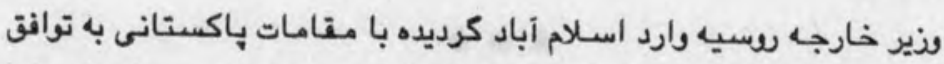

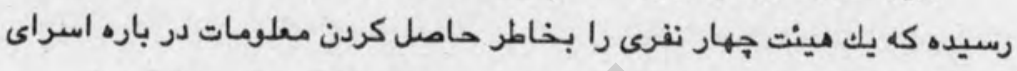
رسىى تعيين نمايد.

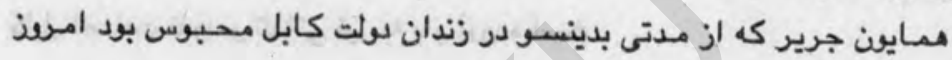
ذريعه وذارت دفاح كابل از حبس رمها كرديد.

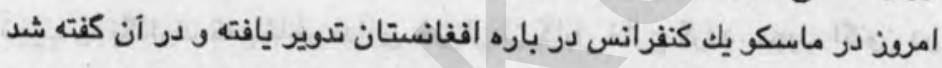

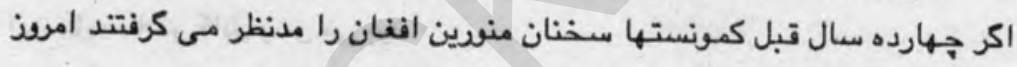
ايريل ra9 V در افغانستان جنين وضع حكمفرما نمى بوده

$8 \%$

ربانى و حكمتيار در منطقه بل جرخى براى بنج ساعت با مم ملاقات نمودند،

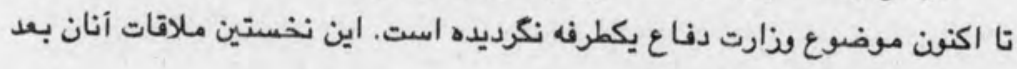
ايريل 199r از معاهده اسلام آباد مى باشد.

اكرم ذكى سكرتر جنرال وذارت خارجه باكستان وارد كابل شد، يك لقذ قبل

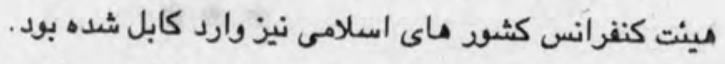

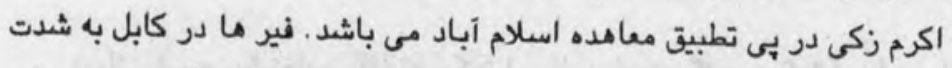

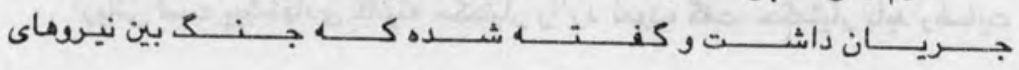




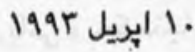

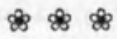

شب كنشته كابل زير ضربات شديد فير هاى راكت قرار كرفت، داكتر عبدالله حزب اسلامى را مسنول اين كار وانمود كرد.

199r إيريل

بنا به كزارش راديو كابل هفتاد و بو راكت از استقامت غرب و جنوب بر شهير

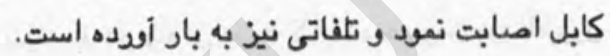

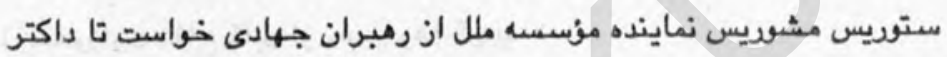

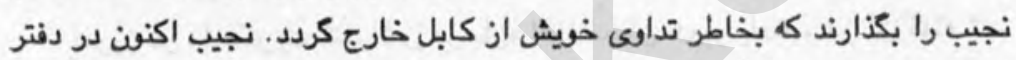

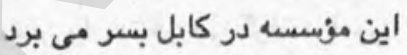

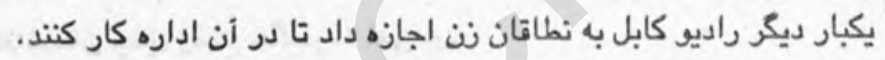

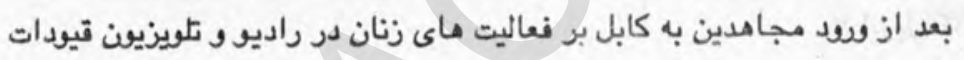
وارد شيده بود. 199r إيريل

مزارى در مودد موافتنامه اسلام آباد كفت: تا اكنون عملى نه شده است و هر رل عده اى از مردم كثته مى شوند . وعى در مردد سه كشور ضامن كفت: بايد آنان در مود فشار وارد نموده و متخلف را سرزنش كنتد.

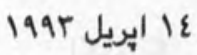

88

ربانى لست يشنهادى كابينه حكمتيار را رد نموده كفت: حكمتيار بايد رضايت 
ينج كروه جهادى را در زمينه بدست أودد.

19910

يك هينت از طرف جنبش ملى وارد تاجكستان شـد تا با مقامـات تاجيك در

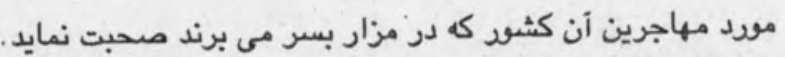

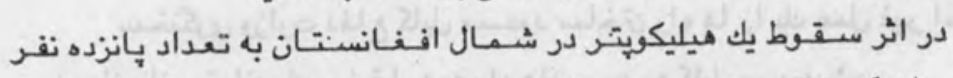

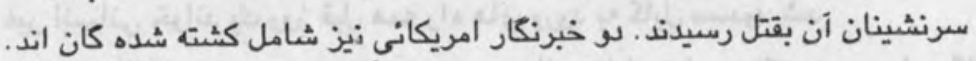
1997 إيريل 19

قطب الدين ملال در مورد كيفيت لست ييشنهادى حكمتيار رششنى انداخته كفت: در آن استاد فريد و احمدشاه مسعود بحيث معاونين مدراعظم معرفى كرديده بوند.

ابريل IV IV

$\& \& 8$

در جنك جهار ردذه قندهار حد اقل جهل نفر كشته شدند و اكنون جنك خاتمه يافته است. 19

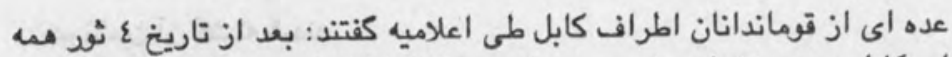

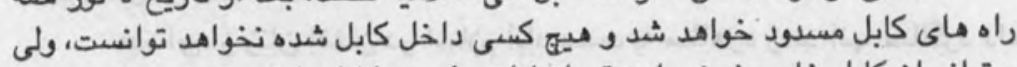

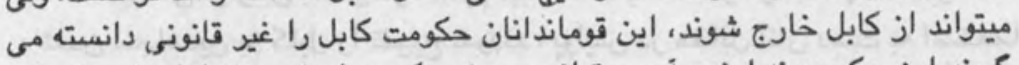

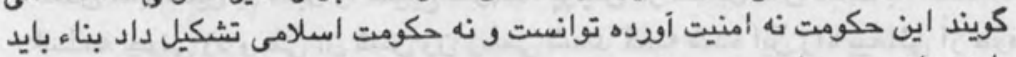

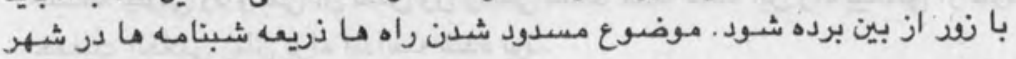

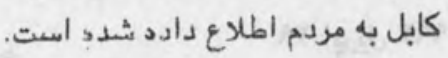

199r r Tr 


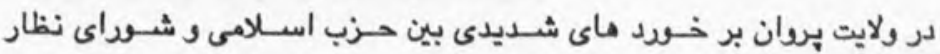

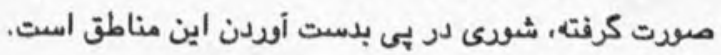

ع إيريل ra

سخنكرى وذارت دفاع كابل مسبرد ساختن راه ها را يك عمل غير اسلامى د

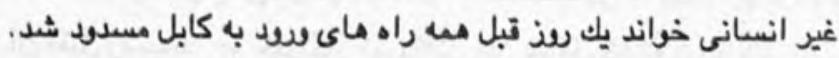

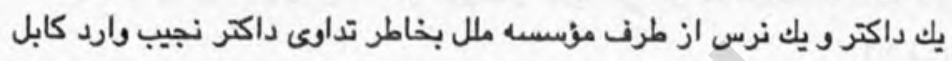

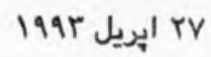
كرديدند.

امريز اولين سالروذ ورد مجاهدين به كابل بود و بنا بـ كذارش راديو كابل اين

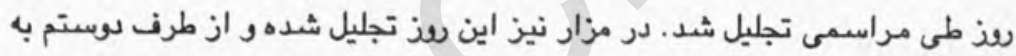

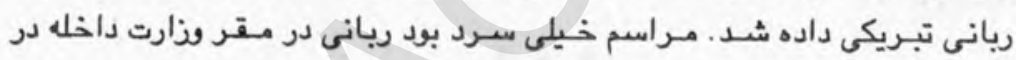

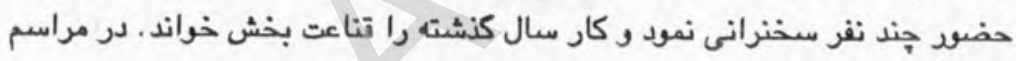
نماينده حزب اسلامى و حزب وحدت اشتراك نونيده بودند.

199r T ايريل

يك هوا بيماى مربوط به بوستم در منطقه تاشقرغان سقوط كرد هفتاد نفر سرنشين أن كثته شدند. عده ايى از زنان افغان در اسلام آباد دست به مظاهره زدند أنها سالكرد داخل

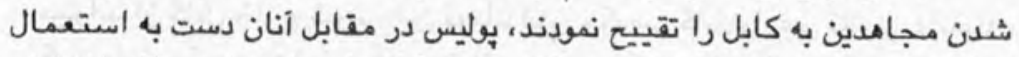

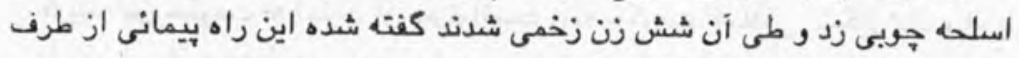
199r Tو إيريل

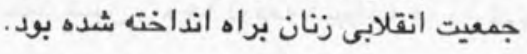


امرون ربانى از كابل وارد بشاود شد و بعد از توقف اندكى بـ جلال أباد رفت

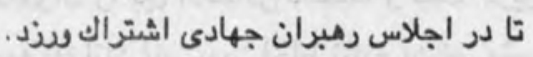
$199 r$ ايريل

جلسـات نتكرهار جريان دارد، فـارق اعظم كفت: در جلسـات جـلال آباد بـ

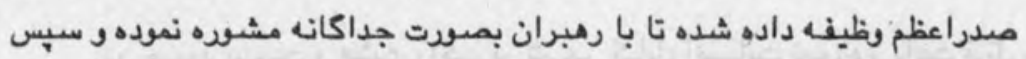
نتيجه مذاكرات خود را به هينت بكويد. عاصم اكرم اولين ديبلوماتى بود كه بعد از ورديت بكريد مجاهدين به فرانسه ارسال

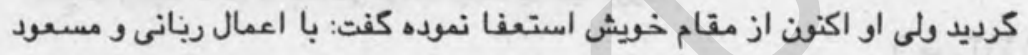

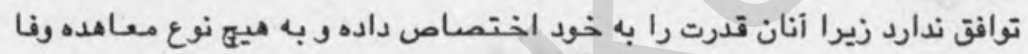

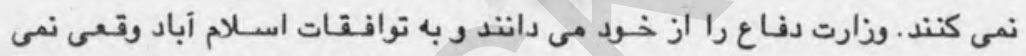

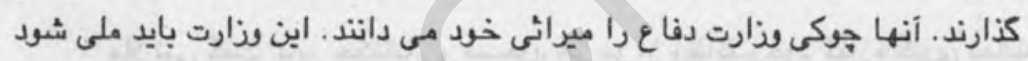
و همه منظمات در آن سهم داشته باشيند. lagr ir or

$\$ \$$

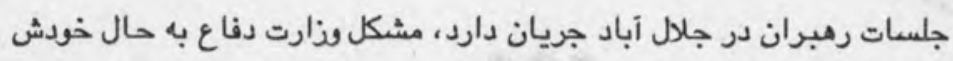

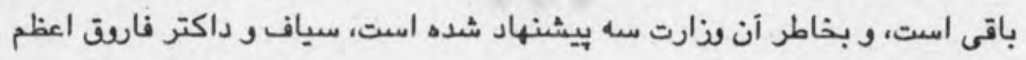
بدين منظور نزد مسعود رفته اند. 1997 ع ع

بخـاطر نبـودن سـياف جلسـات امـرنى نتكرهار مــوقف بود، از جمله سـ

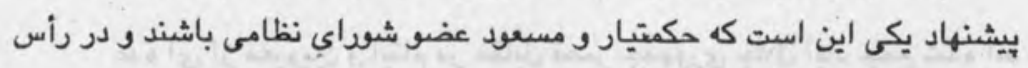
وذارت دفاع شخص سومى باشد.

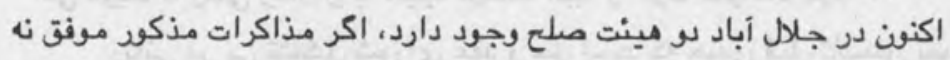

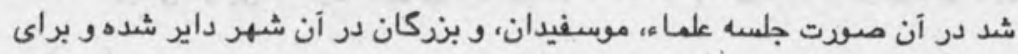


أينده افغانستان تمسيم ميكيرند. حاجى قدير والى ننكرهار اين مذاكرات را بين الافغانى دانسته و كفت: درين

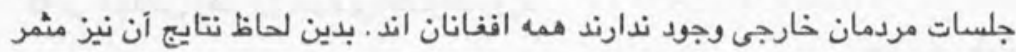

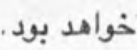
199r مى D

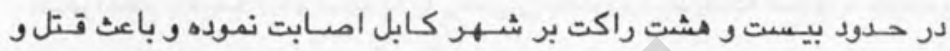

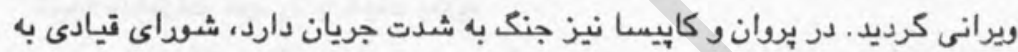

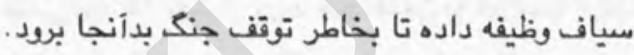
1994 o 7

ملا نبى كفت: بايد حكمتيار و مسعود هر بو از وظائف خود كتاره كيرى نمايند

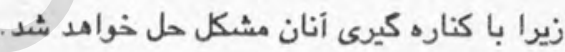
ربانى كفت: بايد حكمتيار بخاطر كابينه خود رأى اعتماد از شودان مداى حل ور عقد

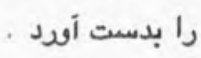
199r 9

از مدت بنج رعذ بديسنو جنك شديد در كابل جريان دارد و اضافه از ـ10 نفر

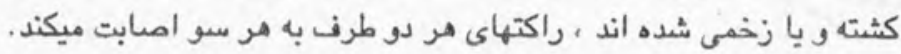
1994 مي 19

عده اى از معيوبين و ايتام در مقابل قمر جمهوىى جلال آباد جمع شده اند و

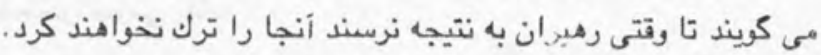

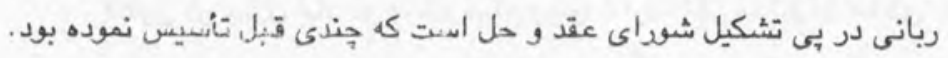


و امرفز يازدهمين سذ جلسات رهبران است تا اكنون به نتيجه نهائى نرسيده اند. و

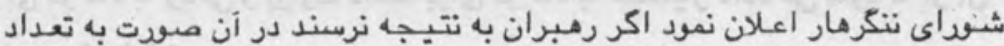

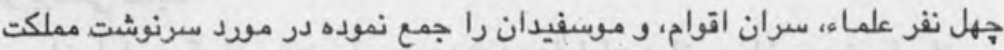
تمسميم نهائى خواهند كرفت

1994 o 11

طى جنكهاى كابل حدود . .7 تن زخمى و يا كشته شدن. غرب كابل مملوء از اجساد كثته شدكان است.

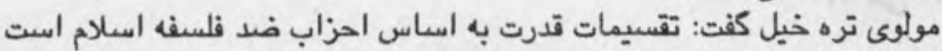

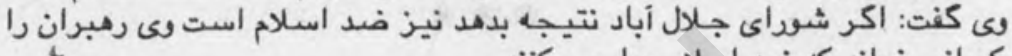
كسانى خواند كه ضد ضدائ اسلام عمل مي كنتد. 199r or

حكمتيار كفت: جانب مقابل به معاهدات خويش وفا نمى كثد، روسيه بانك نوت

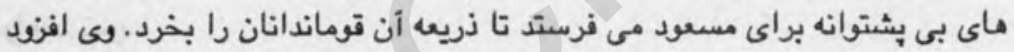

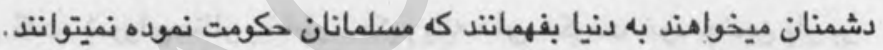

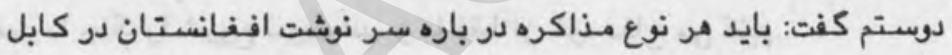
صوت كيرد نه در جا هاى ديكر. 1994 مي 10

جنك در كابل جـريان دارد، طيارات وذارت دفاع مـواضع جانب مقــابل را

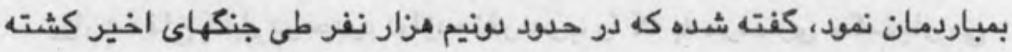
شده اند.

در جلال أباد بيشنهاد شده كه بايد وذارت دفاع و داخله ذريعه يك كميسيون به يش برده شود كه در رأس آن افراد حزب و جمعيت نباشند. 1994 
فارق اعظم كفت: موضسوع اختلافى مذارت دفاع حل شده است رذارت دفاح

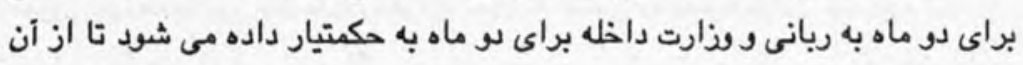
سر برستي نمايند.

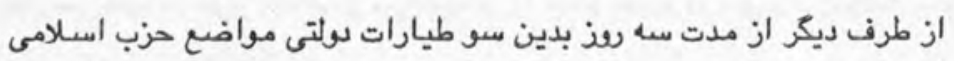
و حزب وحدت را بمباردمان نموده است و در منطقه جهار آسياب در حرد حسود هفتاد نفر زخمى كرديده است.

محمدظاهر شاه سابق از ملل متحد خواست تا در تشكيل حكردان مردم افغانستان همكارى نمايند.

1994 IV IV

$\$ \%$

طبق اخبار بى بى سى در جنكهاى اخير كابل در حسود سه هزار نفر كثته و هزاران نفر ديكر مجروح شده اند.

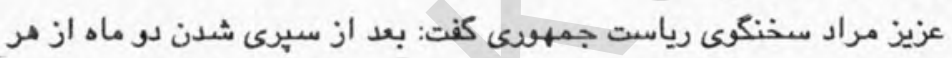

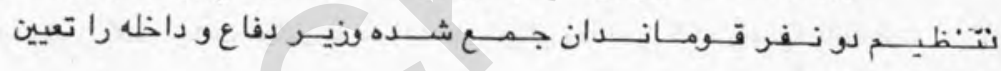

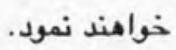

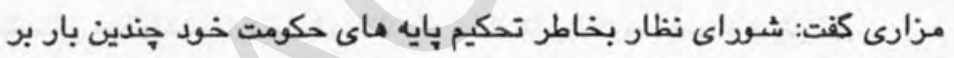

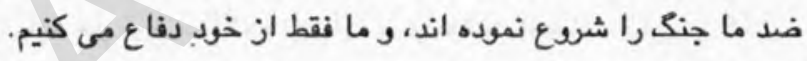
1994 o 11

جلسات نتكرهار آخرين ردزهاى خود را ستخرى ميكند، رهبران بموافقه رسيده

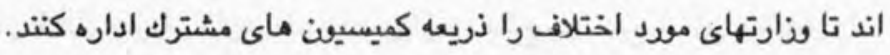

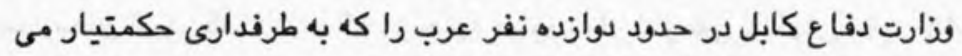
جنكيدند توسط ملا صديق الله دستكير كرد .اكثر آنان الجزائرى و يمنى هستتد. 1994 s 19 
امربذ در تمر جمهردى شهر جلال آباد كابينه جديد از طرف جاجى دين

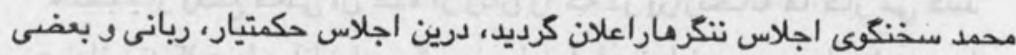
از رهبران ديكر صحبت نمودند. la9r or.

امرذ يكبار ديكر در كابل بعد از بو رن آتش بس مداى فير هاى ثقيل بكوش

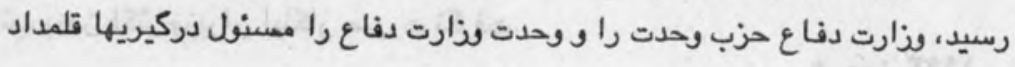

1991 (

ஜ

حكميار كفت: اكر در انتخابات بيريذ شد مسعود را بحيث وذير دفاع خود تعيين خواهد كرد.

1997 s ro

88

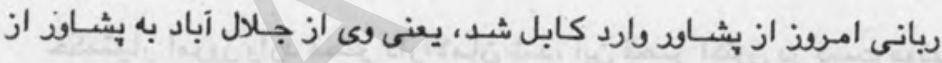

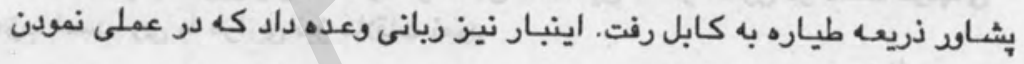
1994 ort

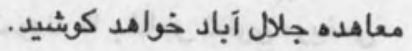

ربانى در مود به كابل آمدن حكمتيار كفت: او خود بايد به كابل داخل شده و

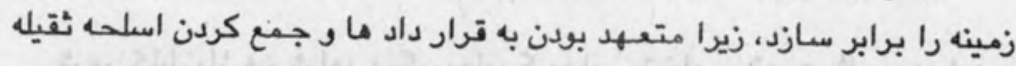
1994 مو شرط اساسى صلح در افغانستان است. 
حكمــــار وضع فـلى آن عده از زنان را كه در وزارتخـانه ها كار مى كنتد

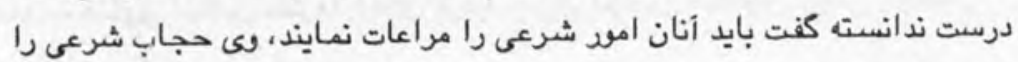
زيو زنان دانست.

ا جن 1991

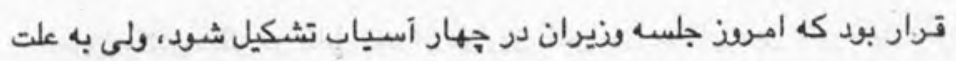

0 جن 1997

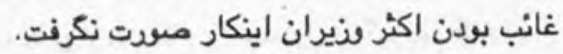
\&\&

كابينه حكمتيار امرون در حضـو ده وزير تشكيل جلسه داد، وزيران مربوط بوريط

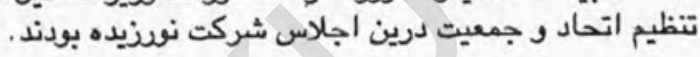

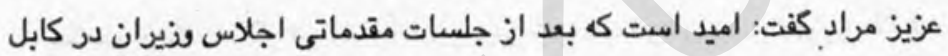
داير شود. قريب الرحمن سعيد كفت: هون شرانط كابل خوب نيست لذا وزيران در

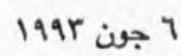

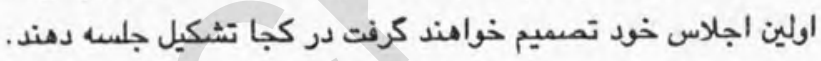
$\$ \$$

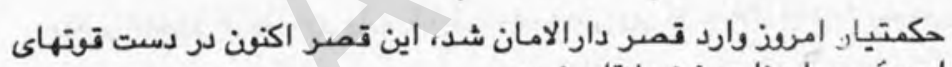

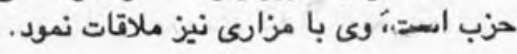

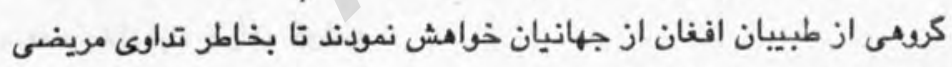
9 سل و ملاريا به كابل دوا بغرستند. कळ

شهـر كابل باز هـ شاهد دركيريهاى كروماى متخامس قدرت طلب بود، اين

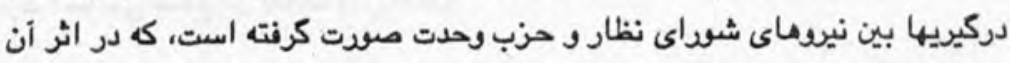

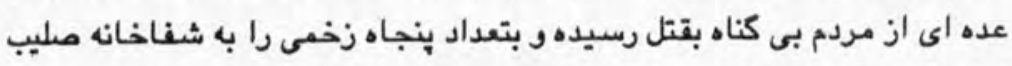
سرخ أودده اند.

|r 
ربانى و حكمتيار در منطقه بغمان در حالى كه سياف نيز وجود داشت باهم

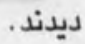

199r

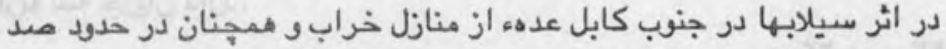
نفر جان ماى خود را از دست دادند، در حاليكه يكعده لا درك كرديده اند. 10 10

امهذ براى اولين بار كميسيون مشترك دفاعى به سر برستى ربانى در تمر

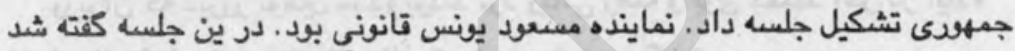

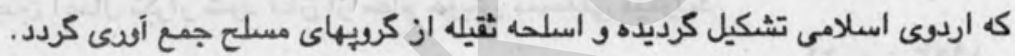
199r 19

\&\&

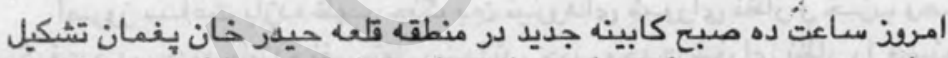

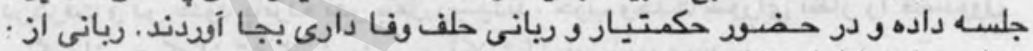

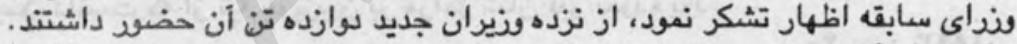

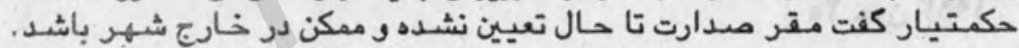

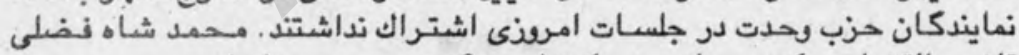
قاضى القضات حكومت ريانى به حكمتيار سوكتد عهده جديد رات ران داد.

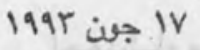

\&\& \&

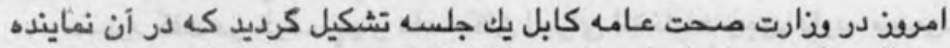

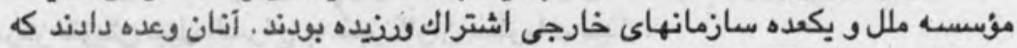
199r Tr در بخش صحت عامه با افغانان ممكاري كنياند. 
يكبار ديكر جنك بين نيروهاى شوداى نظار و حزب وحدت در كرفت. كابينه

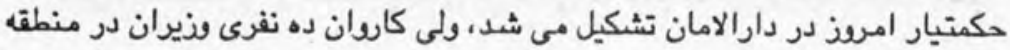
يل جرخى از طرف شواسى نظار توقف داده شد ورذيران مذكود توهين شدند.

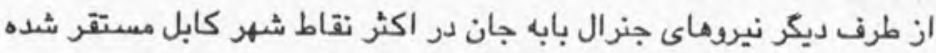

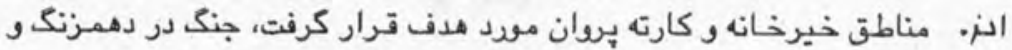

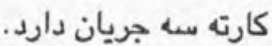

r r r

يكى از مامـوين مؤسسه ملل در غرب افغانستان اعتراف كرد كه افغانان مهاجر مقيم ايران بند از آن كشود بيرين رانده مى شوند

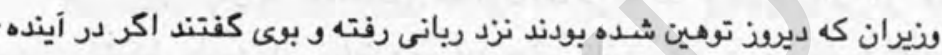
جنين اعمال تكرار شود أنان از مقام خويش مستعفى ميكردند.

ع ع

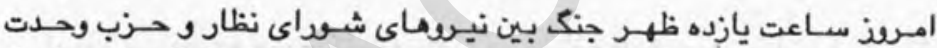

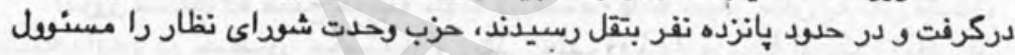
199r ro ro

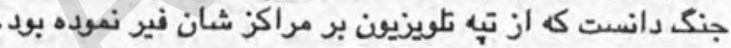

احمدشاه مسعود كفت: نظر خودش حنين بود تا شـوراى متشكل از همــ

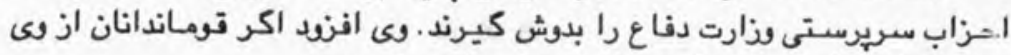

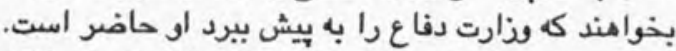

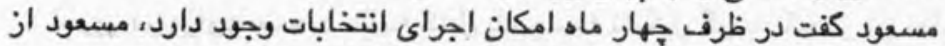
199r ra

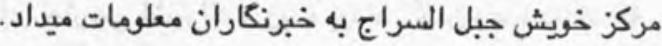


حكمتيار در بى تشكيل يك تقوت مشترك دفاعى از همه منظمات است تا امنيت

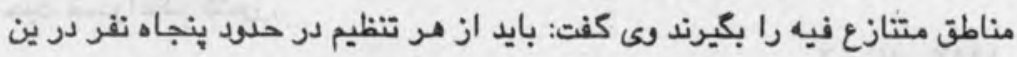

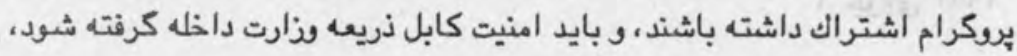

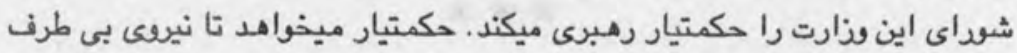
به قسم حايل در مناطق دركير جابجا شوند.

199r ror.

بوستم با شمست تن از همراهان خويش ذريعه بنج طياره بكابل آمد، اين اولين

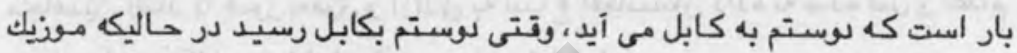

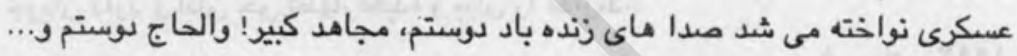

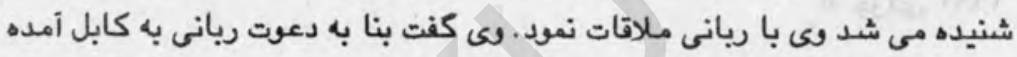
تا در باره مشكلات خويش با آنان مذاكره نمايد.

r

ربانى در رأس يك هينت به تركيه رفت و كفيل وكى در رياست جمهوبى دوبتم

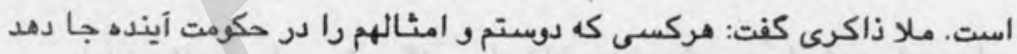

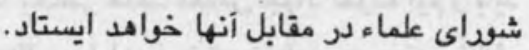
ع جولاى

از مدت سـ سذ بدين سـو كابل زير ضـربات راكتهاي كور قرار دارد، راديو كابل مى كويد كه فير از طرف جنوب كابل صورت مى كيرد.

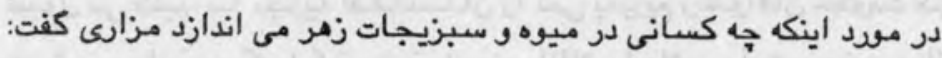

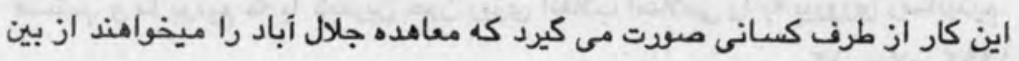
ببرند و مدراعظم جديد را بدنام سازند. بوستم كفت: حاضر است با حكمتيار بحيث رئيس يك تنظيم ملاقات كند نه به به 


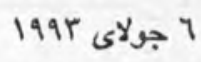

$\& \&$

حكمتيار كفت: دوستم ميتواند در بر قرارى صلح در افغانستان نقش مهمى را

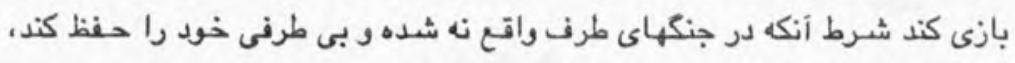

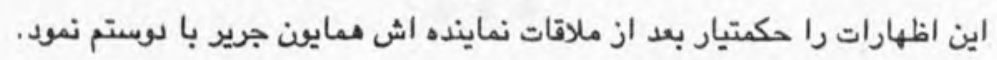

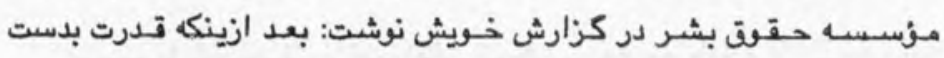

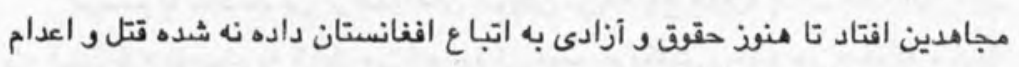
جريان دارد و آنان حق اظهارعقيده و بيان را ندارند.

1 جولاي 1994

امروذ دوستم در منطقه بالاحمعار در يكى از مراكز حزب اسلامى با حكمتيار

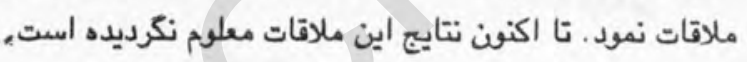

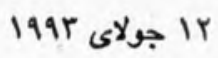

$\$$

نماينده اتحاد حاجى بشير كفت: ما بخاطر مدف مقدس جهاد نموده ايم و بايد

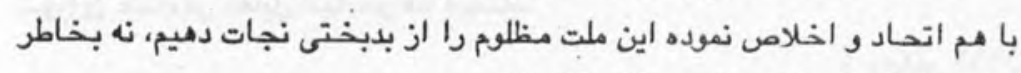
رقابت با يكنيكر با كروهاى مخالف كنار آنيم.

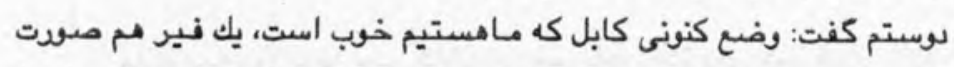

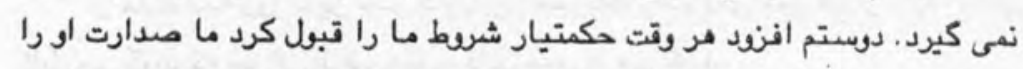

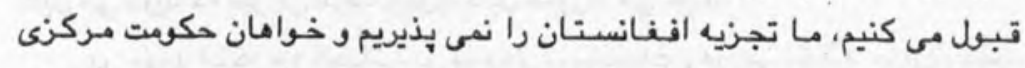
هستيم. و ما بوديم كه با كترين خون ريزى انقلاب اسلامى را به بيرنئى رسانيديم.

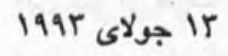


سياف كفت: بعد از تشكيل حكومت موقت كه زريعه آن قدرت به مجاهدين

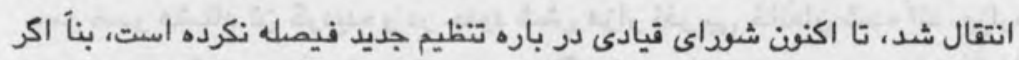

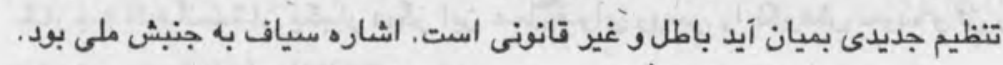

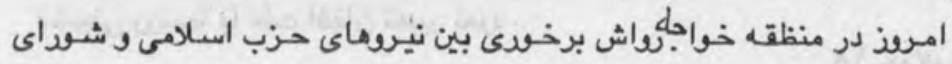

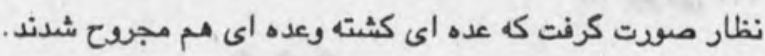

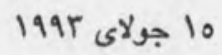

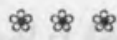

وزير دفاع روسيه باول كرافتجك به تاجكستان رسيده، درين اواخر مهاجرين

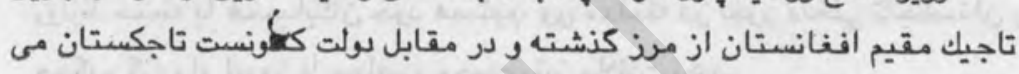

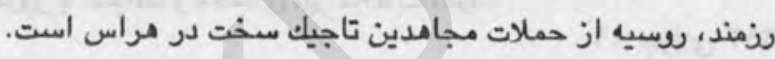

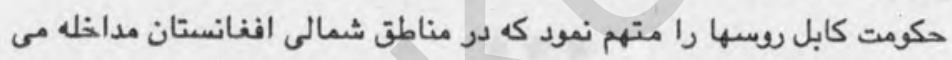

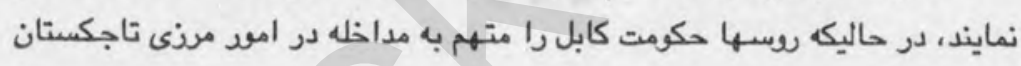
179 مى نمايند.

\section{की मे के}

وذارت خارجه افغانستان حملات كشور هاى مشترك المنافع روسيه از خال

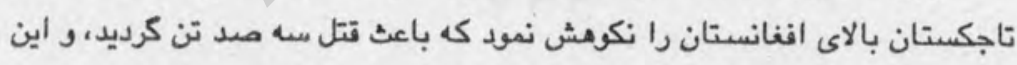

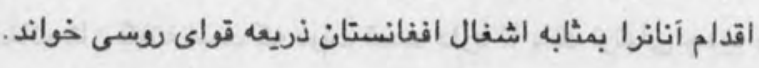

امرئ جلسه فوق العاده وزيران داير شده و در أن همله روسها تقبيح شد و

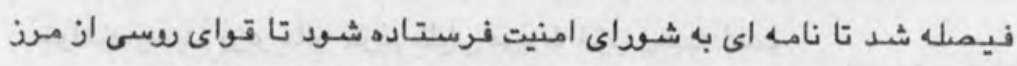

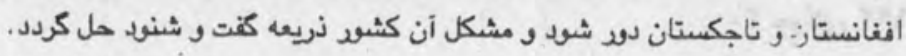

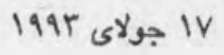

$\$ \approx$

حملات تويخانه بوسبا بر مناطق مختلف ولايت تخار ادامه دارد كه باعث قتل 
سه مسو هشتاد تن كرديده و در حدود شش هزار نغر بى خانمان شده اند ـ وذارت

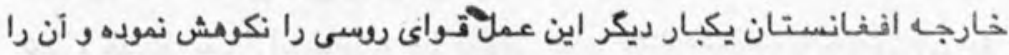
11 دشمنى رسبها با ملت افنان تعبير نمود.

حكمتيار كفت: ما حملات سسبها را شديدأ محكوم مى كنيم و به رسبها توصيه

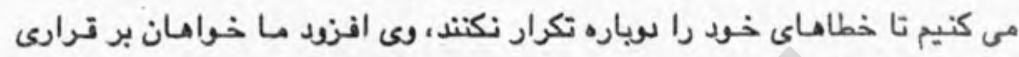

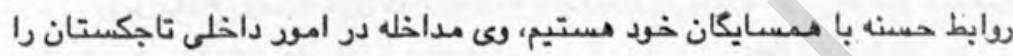

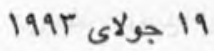

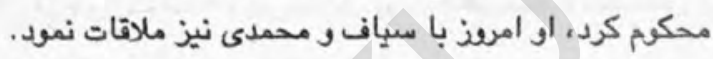
$\$ \$$

حكمتيار از نماينده مؤسسه ملل تقاضا نمود تا تحت نظلارت اين مؤسسه

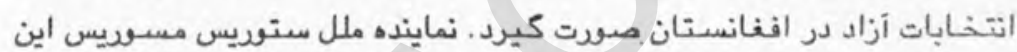
تقاضا را يك اقدام نيك خوانده و خواهان معلومات در باره جكونكى انتخابات كرديد.

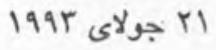

وذير ماليه افغانستان كفته است كه دولت قمد دارد تا بانك نوتهاى جديد را طبع و در عوض نوتهاى سابقه توزيع كند، در ين مودد رئيس دولت نيز موافقه نموده

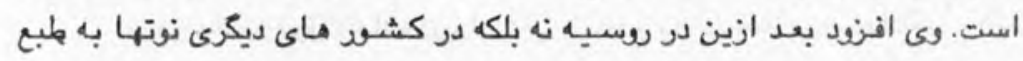

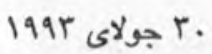

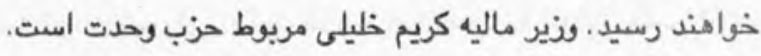
$\& \&$ حمتيار كفت: حاضر است شيخ عمر عبدالرحمن را بحيث يك مـهاجر در كشوش جا دهد، ولمى نميخواهد در زمينه برايى حكومت مصر مشكلى ايجاد كند

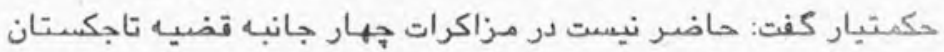




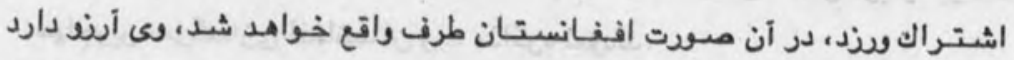

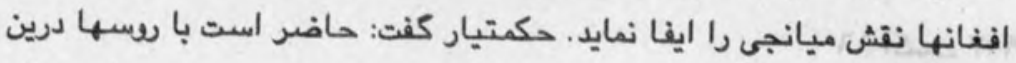

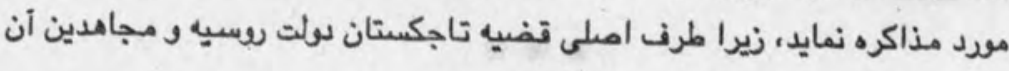
سر زمين اند.

ا 1994

\section{$8 \%$}

كابل يكبار ديكر زير ضربات موشكى قرار كرفت. عزيز مراد كفت: اين راكتها

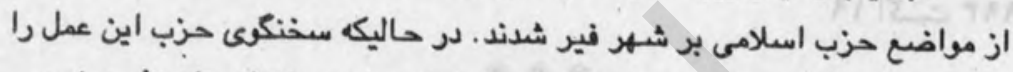

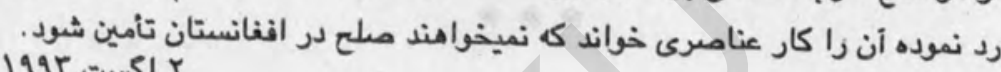

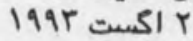

يك نفر افغان بنام اكبر بهائى در قروقريشى در كشمير اشغالى ذريعه عساكر

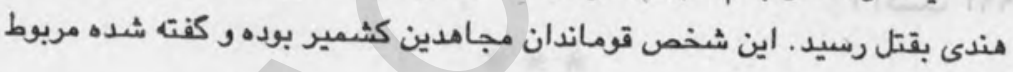
V I I I I تنظيم حكمتيار بود.

$\approx \%$

در اثر زد وخود هاى امرنىى (جنك قدرت) در كابل ليسه حبيبيه نيز طعهـ

1994 ت 19 حريق كرديد و جندين نفر بقتل رسيدند.

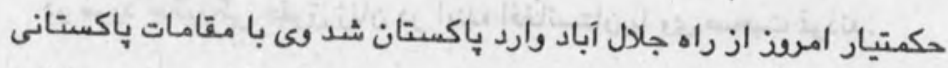

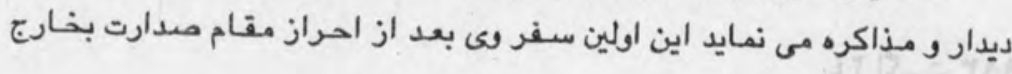

1 1995 199 كشقر مى باشد. 


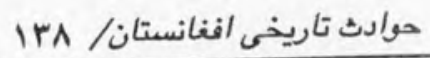

هـين قـريشى صسدراعظم با حكمتيار مـلاقـات نمود، أنان درباره بركشت

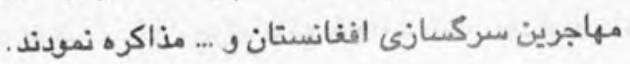

$199 r=5117$

888

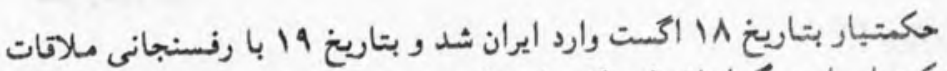

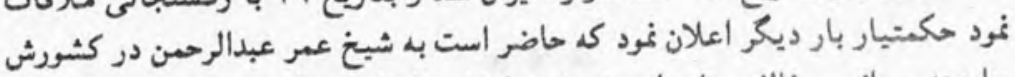

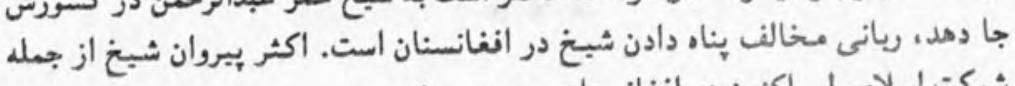

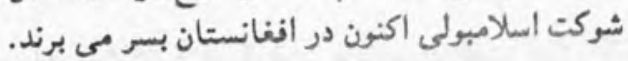

$1994=319$

$\& \&$

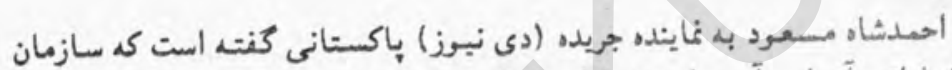

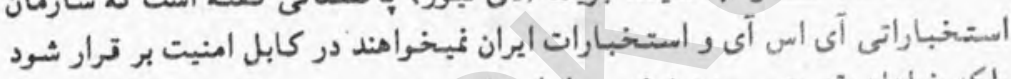

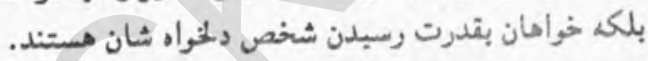

$199 \%=$

در اثر بنكهاي ذات البـينى مسجاهدين در قندهار در حدود بانزده نفر بقـل رسبد.

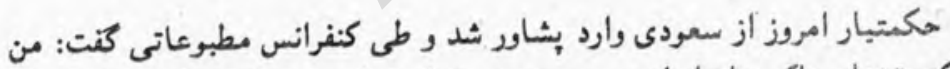

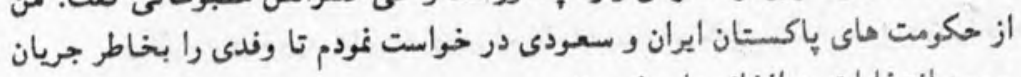

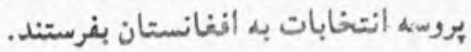

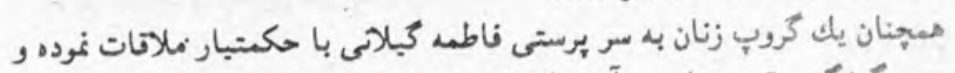

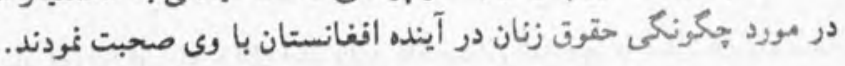

1994 ت

$\$ 28$

توماندان شيالى ذريعه اشـاض ناشناس در شهر جلال آباد بقتل رسبد، وى 
استمبر V V

عضو شوراى جلال آباد بود. بنج تن ديكر نيز با وى كشته شدند.

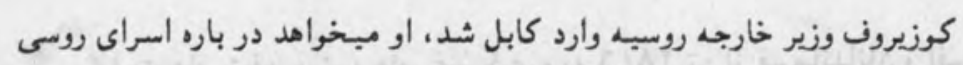

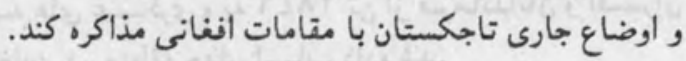

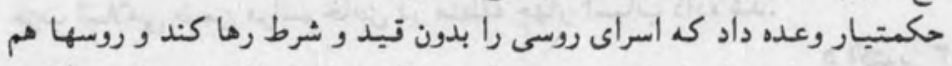

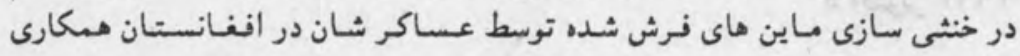
1994

جلال الدين حقانى در مورد حكومت كابل كفت: اداره فعلى كابل اداره مشترك ادرك

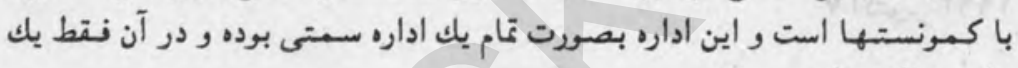
1994

$$
\text { مليت شركت دارد. }
$$

\section{$\& \& 8$}

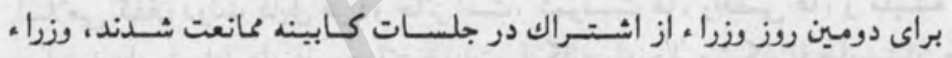

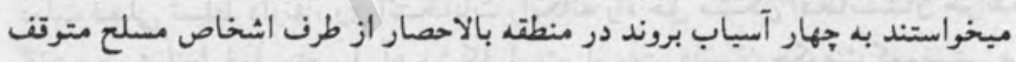

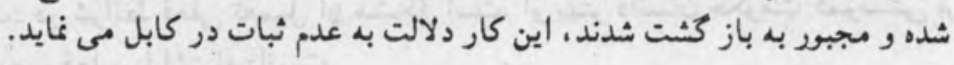
1994 و 19

هكتيار در باز3شـائى بوهنتون كابل كفت: همه اعضاى كابينه بايد استعفا

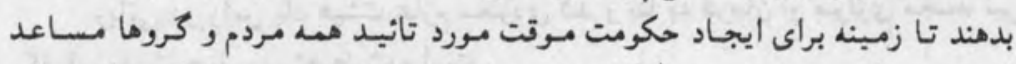

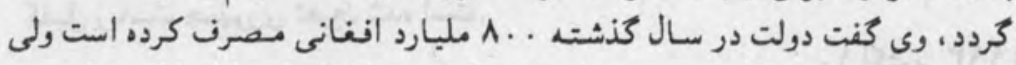

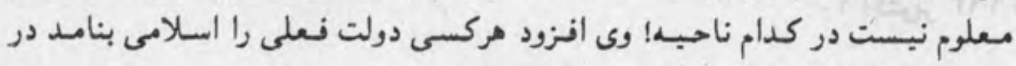
1994 r r r حقيقت اسلام را بدنام كرده است. 


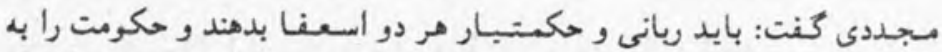

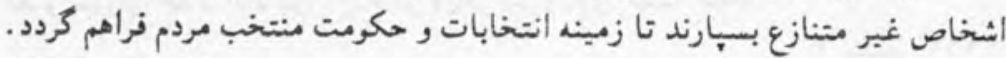

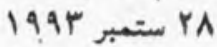

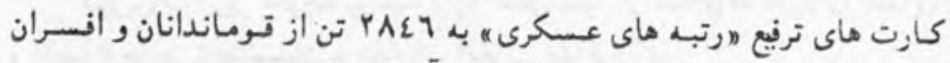

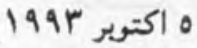

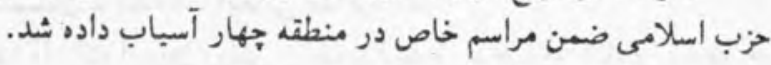
$\not 8$

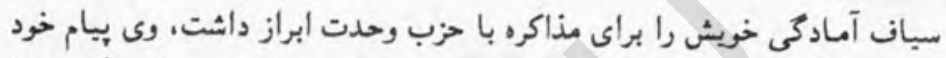

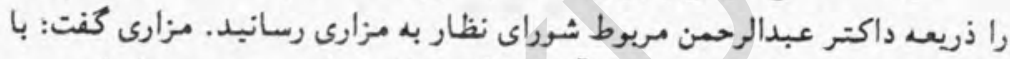

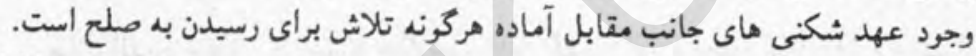

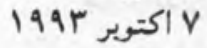

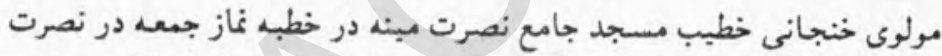

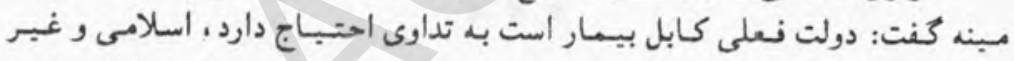

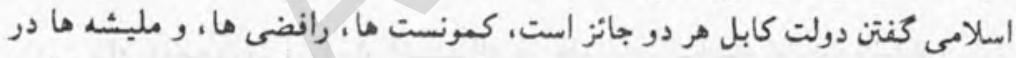

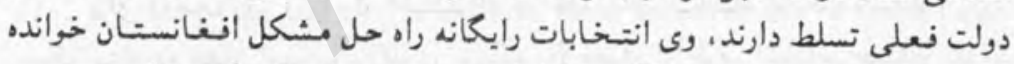

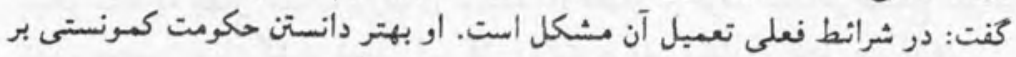
19

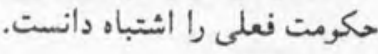

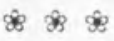

ربانى در رأس يك هييت عازم سعودى شد و بنا به فرمان او مولوى محمد نبى

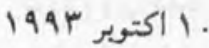
كفيل رياست جمهورى تعيين شده است.

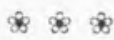

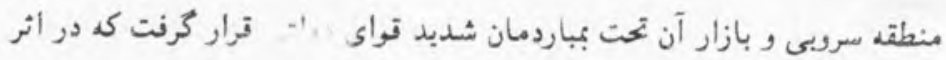


آن قريم ها خراب و عده زيادى از مردم بقتل رسيدند كتته شده كه بند برق نغلو نيز از

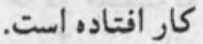

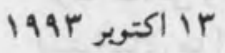

$\$ \& \&$

حكتبار و مزارى در تصر دارالامان ملاقت نمودند، اين ملاقات بيش از يكنبم

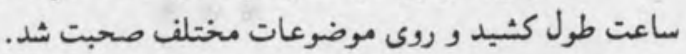

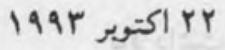

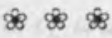

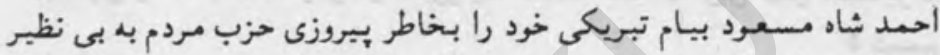

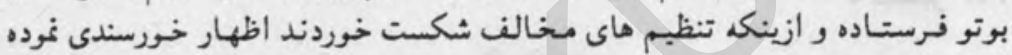

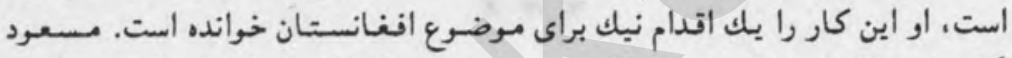

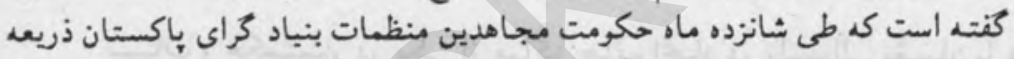

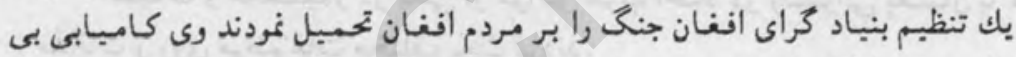

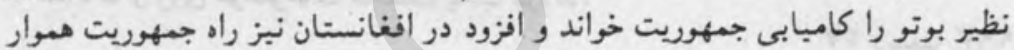

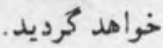

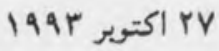

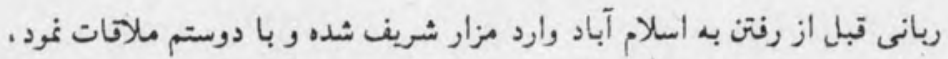

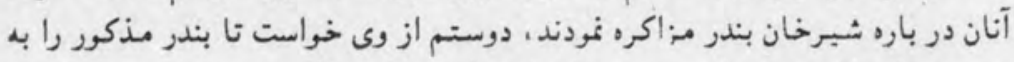

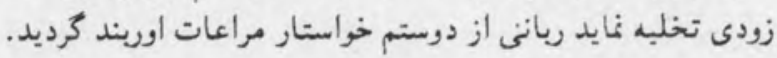
19

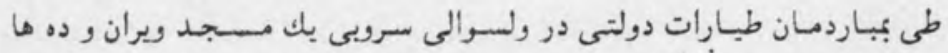

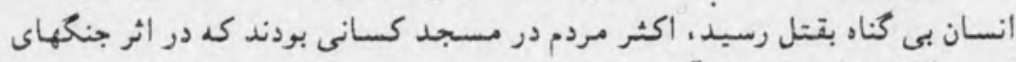
اخير نكاب به سروبى يناه آورده بودند.

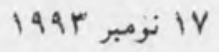


حوادث تاريخى افغانستان/

احمد شاه مسعود در كفتحو با (مجله الوطن العربى) كفت: ما در حقيقت نه با

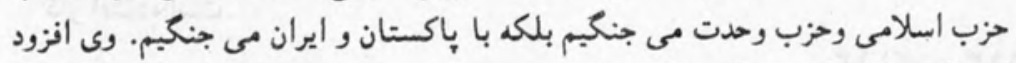

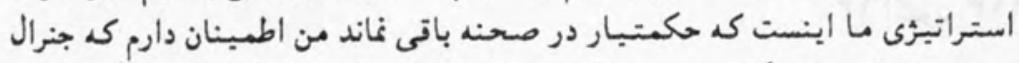

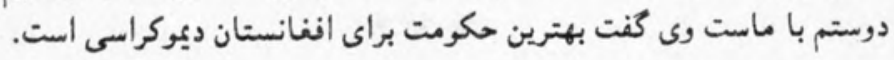
1994 r

ياد داشت احتتجاجيه حكتبار به سفير روسيه در اسلام آباد داده شـد. در ياد

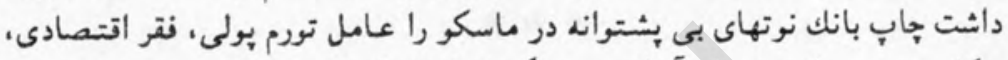

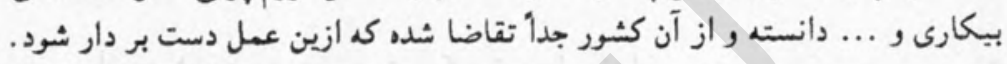
1994 دمبرو 19

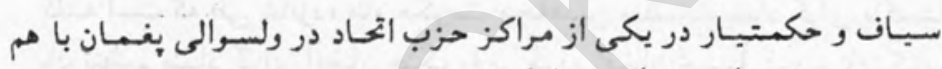
ملاقات و روى موضوعات منتلف بحث نمودند. 1997 TrV 


\section{مال 1994.}

جنح شـديدى در كابل از اول جنورى سال عاله شروع كرديد تا اكنون اكثر نقاط 1992 اجنوزى 1

شهر بدست نبروهاي مخالف افتاده است.

$$
\text { * * * }
$$

ربانى بر ضد جنبش ملى اعلان جهاد نود ، و, كروهاى مقابل هـ شامل فتواى جناب ربانى مبباشند. 1992 جنور

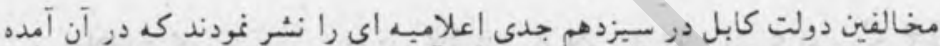

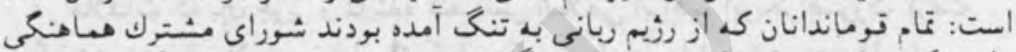

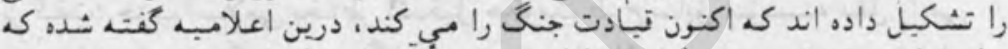

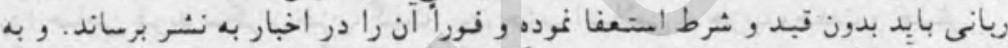

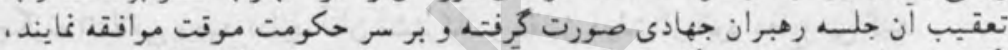

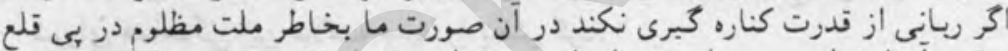

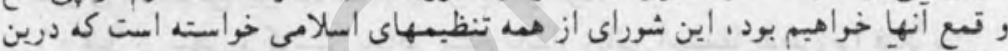
r برنامد با آنان همقدم شوند.

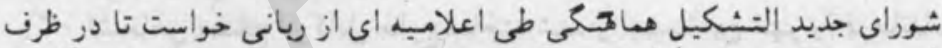

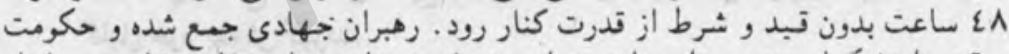

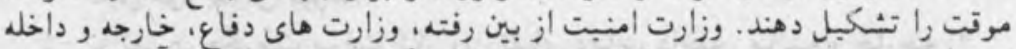

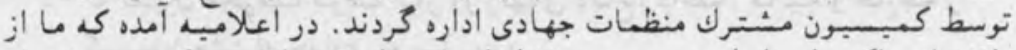

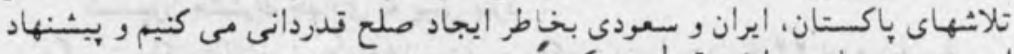
1998 (19.

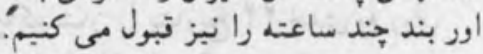

(2) क्ष

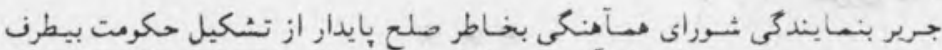

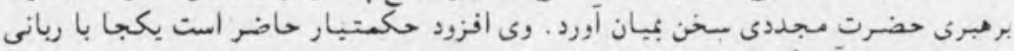

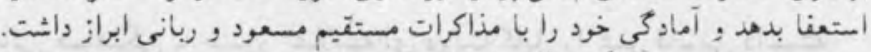
V

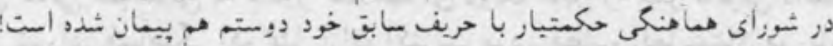




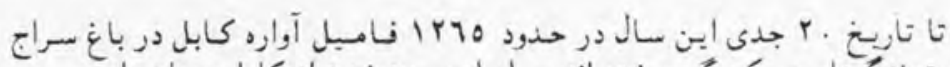

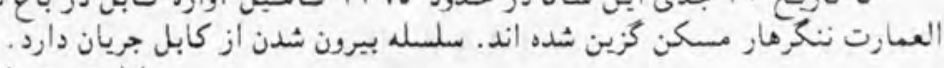
1992 (1) 11

$x+\infty$

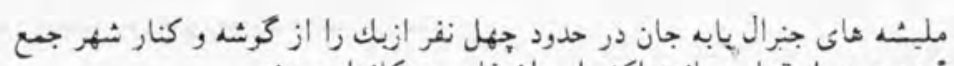

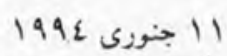

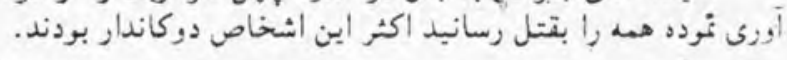

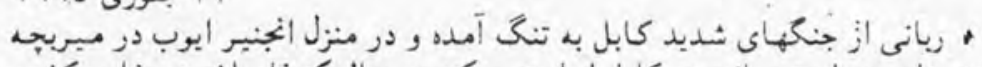

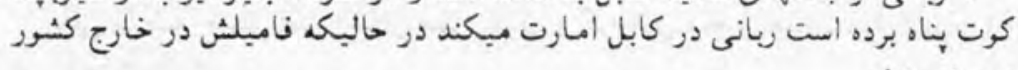

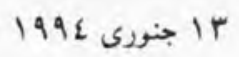
بسر مهى برد .

\section{$\dot{*} * \hat{x}$}

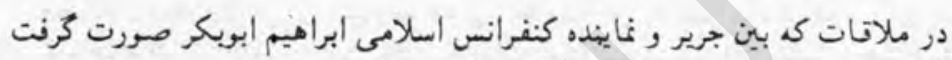

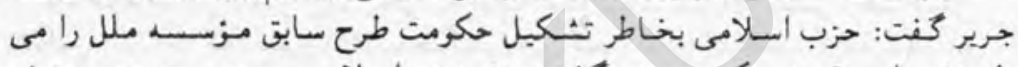

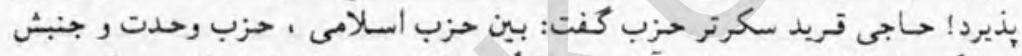

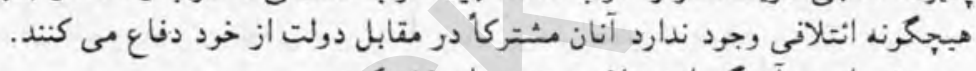

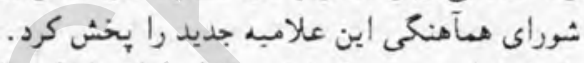

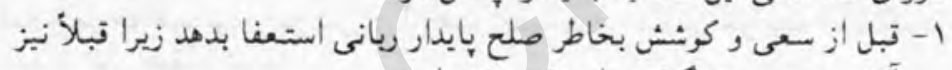

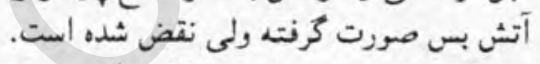

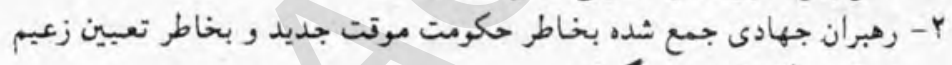

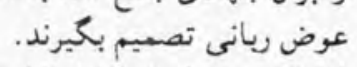

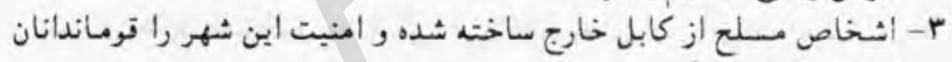
كابل خود بدوش كيرند.

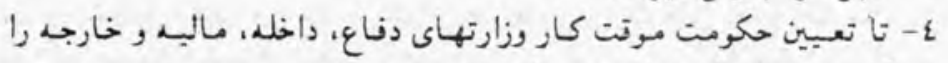

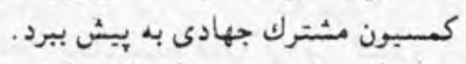

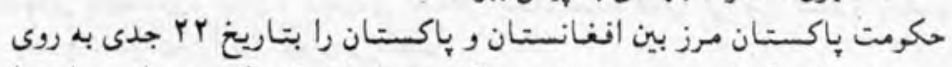

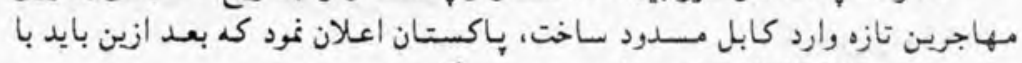

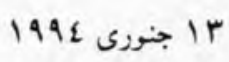
مهاجرين در داخل افغانستان مساعدت صورت كابل كيرد.

$$
\text { 2. } 20
$$

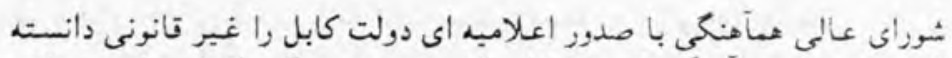

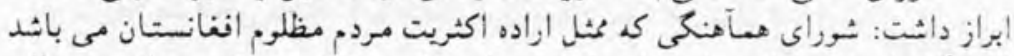

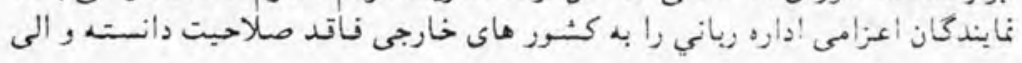


تشكيل حكومت قانونى موقت و طرن تائبد همه تنظيمها و مردم افغانستان، هركونه

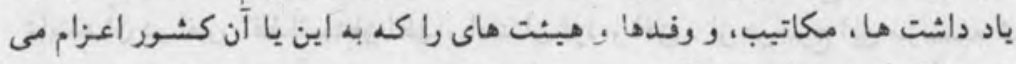

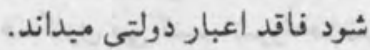

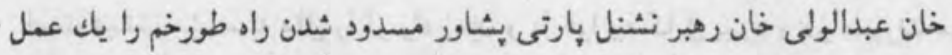

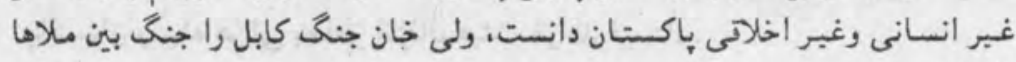
باد كرد.

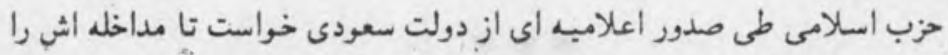

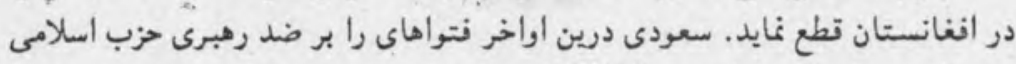

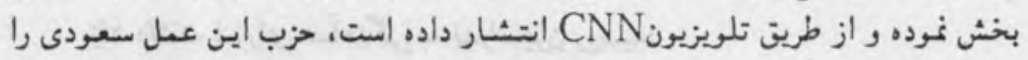
1992 محكوم كرد.

\section{8}

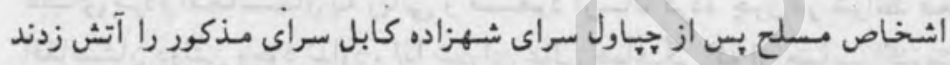

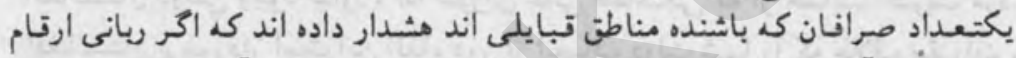

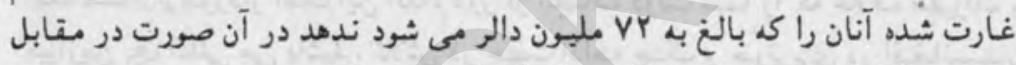

\section{$199 \varepsilon$ إين 19}

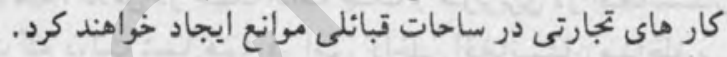

شوراى همآهنكى در اعلامبه اش جنين كفت: قوماندانان اين شورا در كابل طي جني

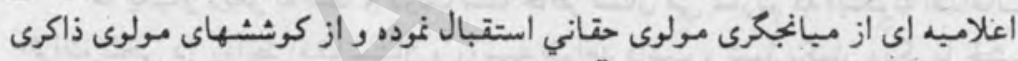

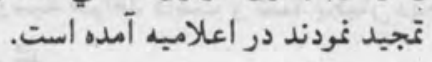

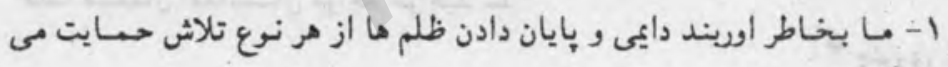

$$
\text { كنيم. }
$$

r- اكر جانب مقابل اصرار به جنگ كند ما برايش جواب داب دندان شكن ميدهيم.

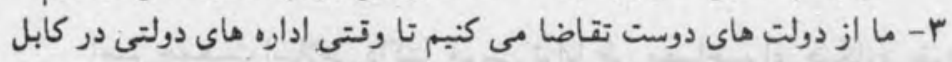

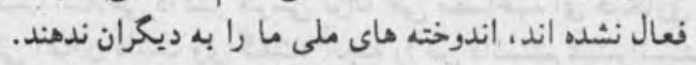

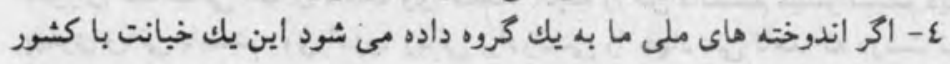

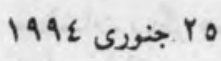




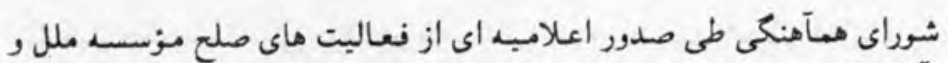

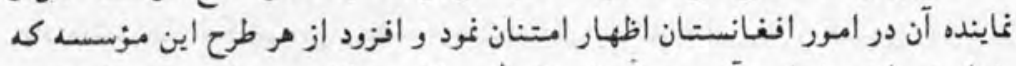

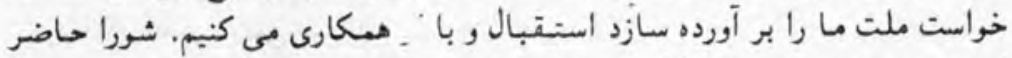

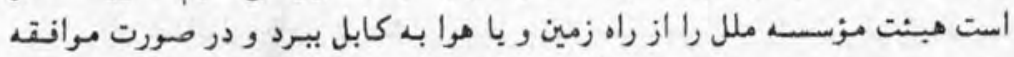

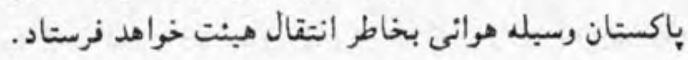

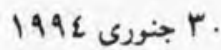

\section{ياذ داشت شوراى مهآهنكى به فدراسيون روسبه:

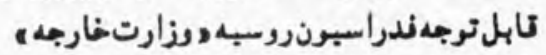

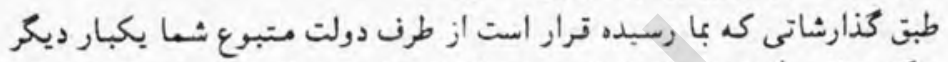

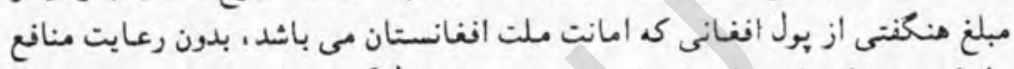

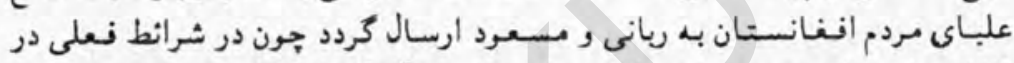

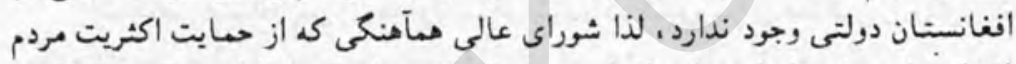

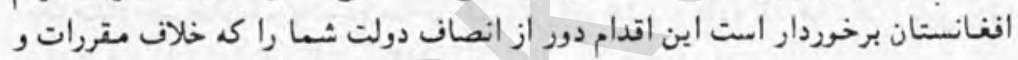

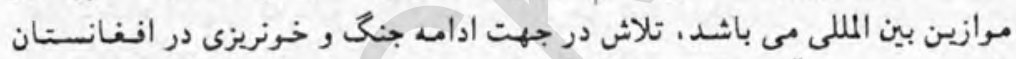

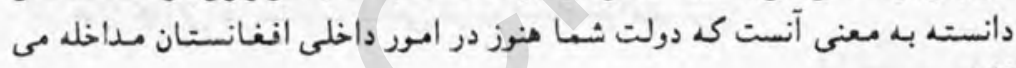
نمابد.

ما بكبار ديكر به شما و دولت شما خاطر نشـان مي سازيم كه اينكونه اتدامات

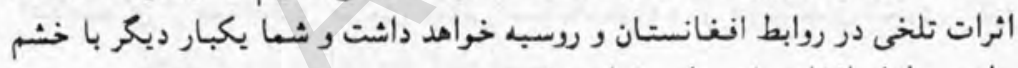
1992 19ن r.

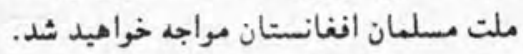

$\$ \$$

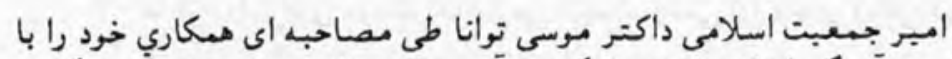

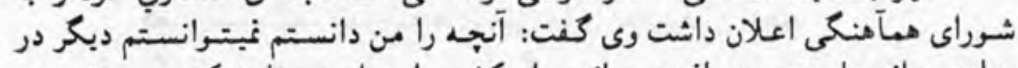

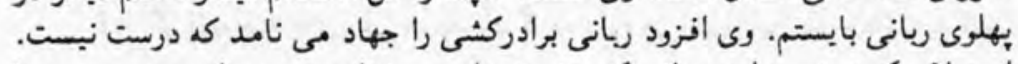

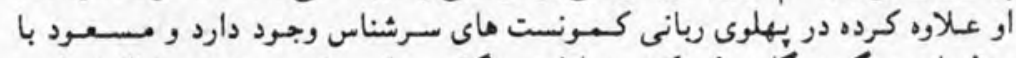

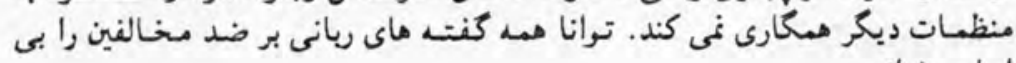

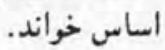
| $199\{$ | 
طرح جديد شوراى مهآهنكى بخاطر اعاده صلع عاجل دركشور:

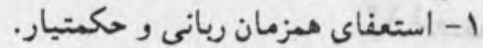

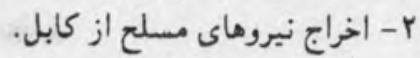

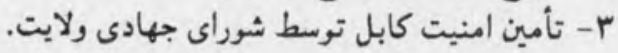

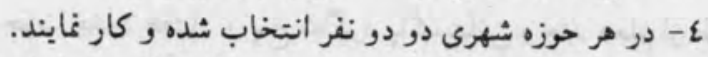

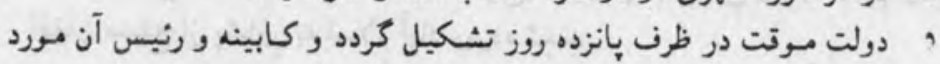

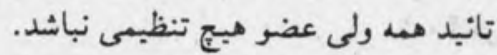

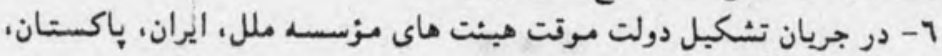
سعودى و تركيه نظارت نمايند.

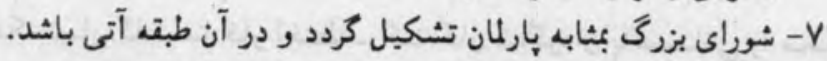

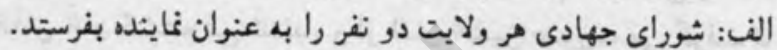

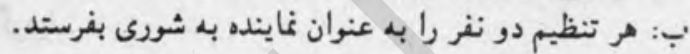

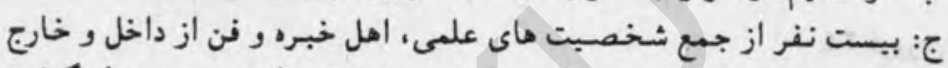

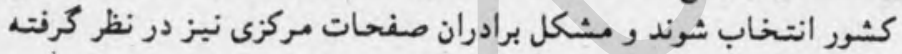
^- هر تنظيم ده نفر از افراد مسلمان و خبر خـواه خود را به هينت هاى ناظر

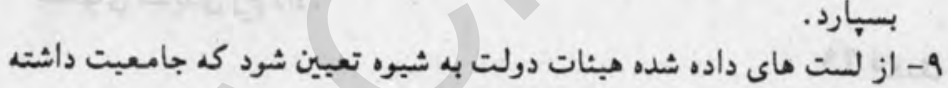
و حضور مردم را در شورى تمثيل كند. . - حكومت موقت در دوران كارش به وظايف آتى اهتمام ورزد : الف: بركزارى انتخابات. ب: تشكيل دولت منتخب اسلامى.

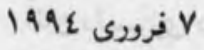

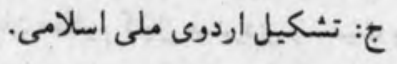
\& $\$$

شوراى مهآهنكى آتش بس مشروط جهار روزه را اعلان نمود طى اين مدت بايدة

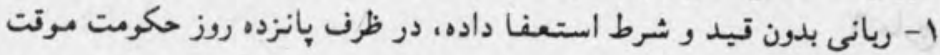
تشكيل كردو.

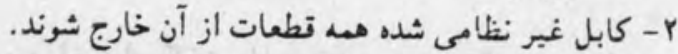

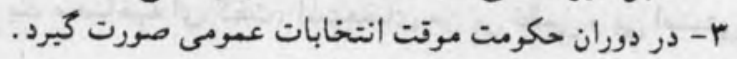




$$
\text { ع - امنيت كابل را مجاهدين كابل خود بدوش كيرند. }
$$

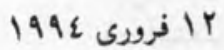

بتاريخ أول حوت حدود هنتاد و بنج شاكرد باكستانى و جند معلم از طرن سه

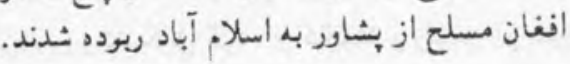

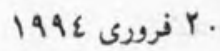

\section{$\infty \&$}

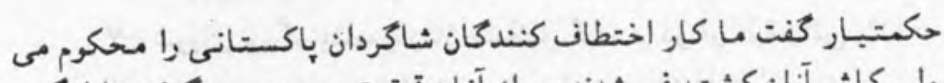

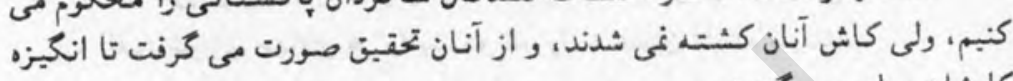
كارشان معلوم مى كرديد. | ع كرورى 1999

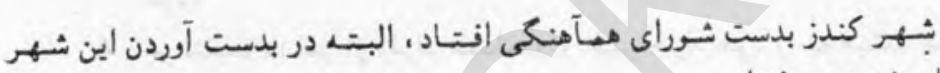
جنكهاى شديدى رخ داد.

4 Y فرورى 1994

$\$ \& \&$

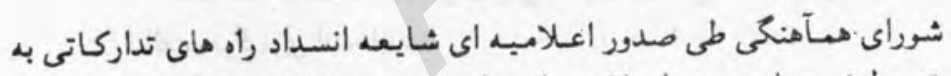

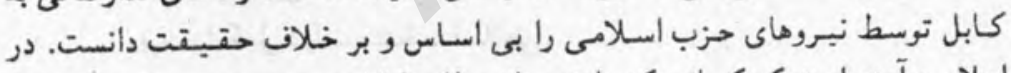

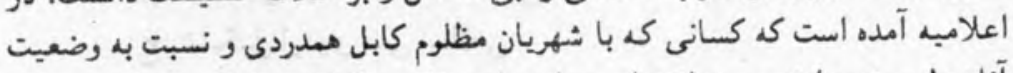

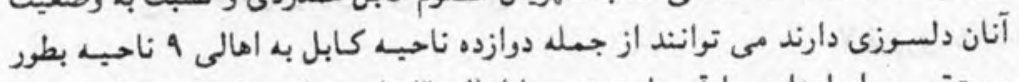

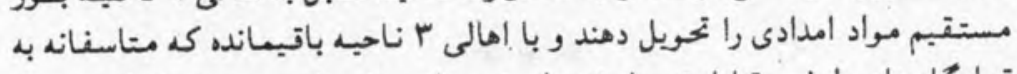

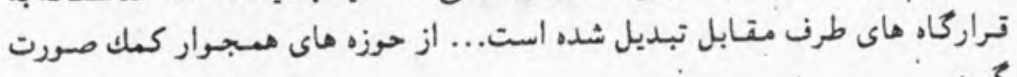
كيرد. 1998 198

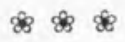

ربانى طى يك مصاحبه اي كفت: استعفاى من بى نظىى و بى امنيتى را در 
/ احواثث تاريخى افغانستان

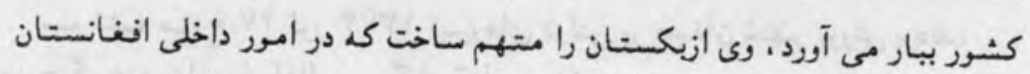
1992 Pار

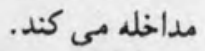

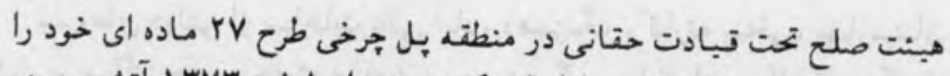

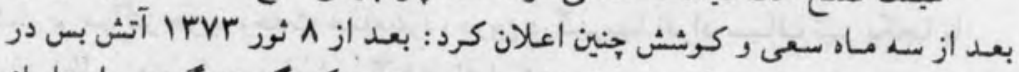

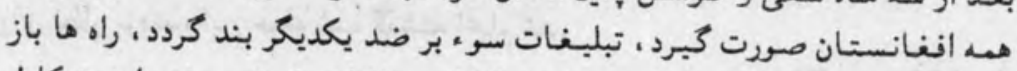

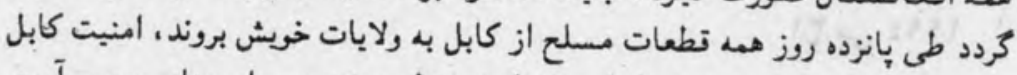

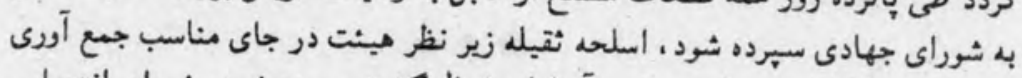

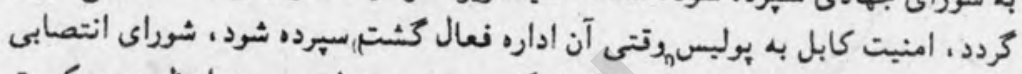

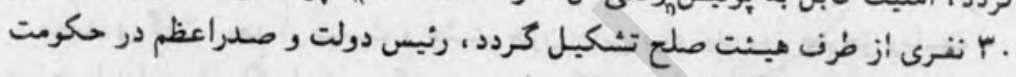

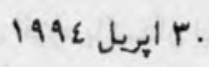

انتخابى كانديد شده نمبتوانند.

مولوى خالص طرح صلح حقانى را بـ مثيابه موعظه دانست و افزود كه جناب 1992 (1) شان بدان طرح خوشبين نبستنر.

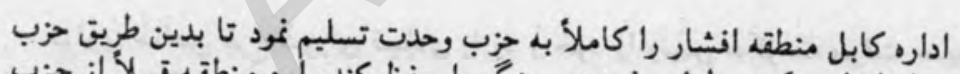

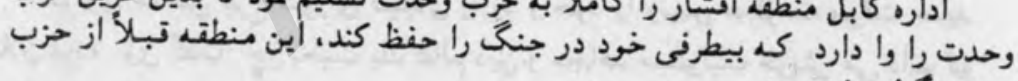
$199 \varepsilon$ ع 19 وحدت كرفته شده بوده.

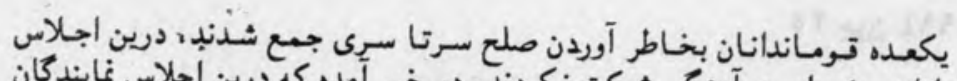

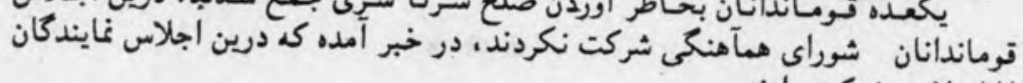

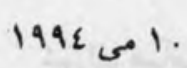
V واندانان شركت دارند 


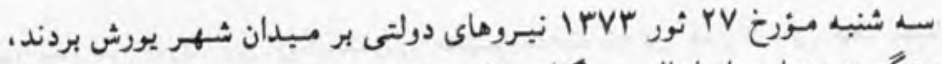

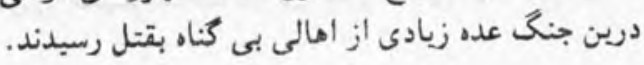

19 1992 199

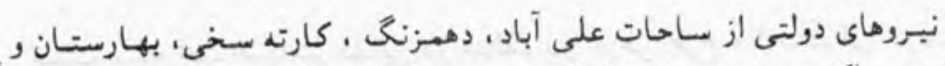

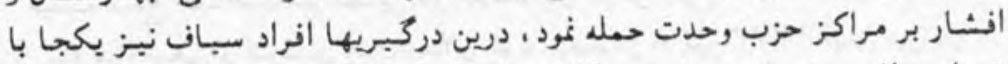

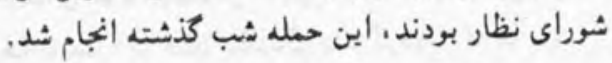

1 1992

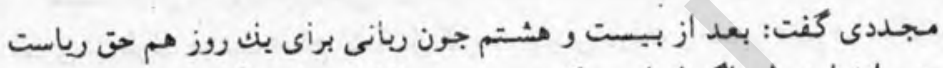

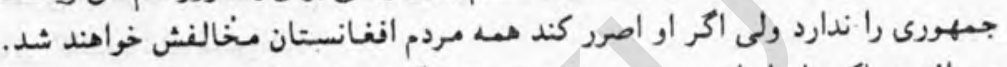

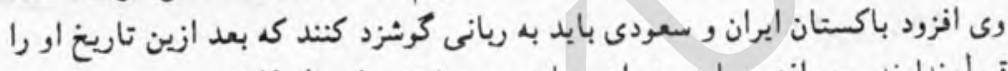

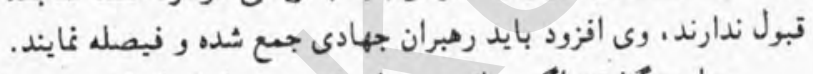

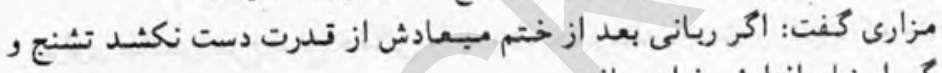
بيجبد3ى اوضاع افزابش خراهد يانت.

ا ا جون 1992

$\$ \&$

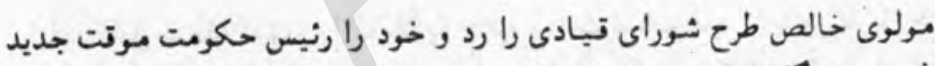

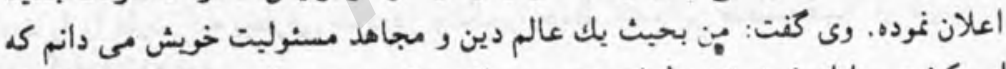

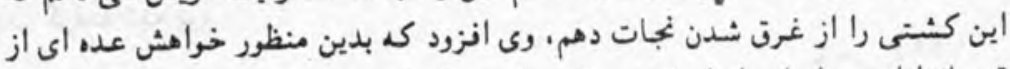

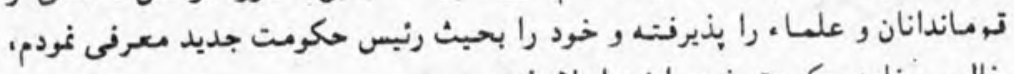

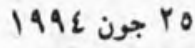
خالص برنامه حكومت خود را نبز اعلام نمود.

$\$ 28$

شوراى هـآهنكى طى صدور اعلامبه ایى در باره دولت ربانى كفت:

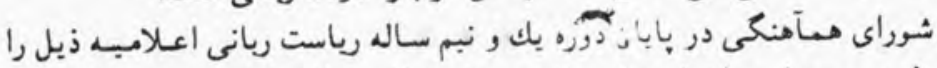

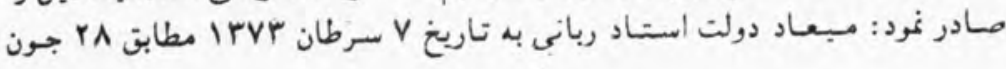




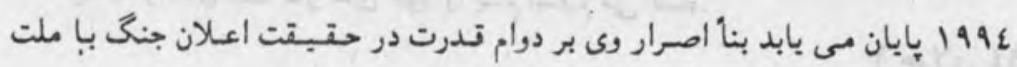
مزمن افغان است.

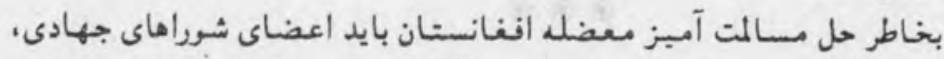

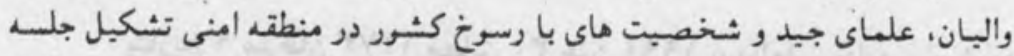

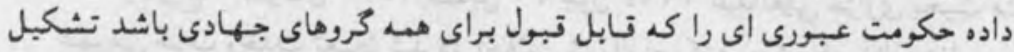

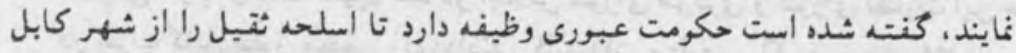

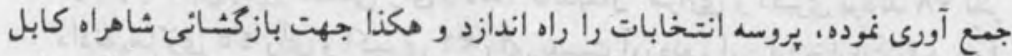

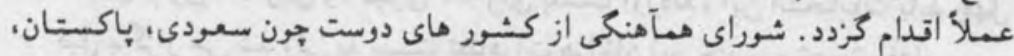

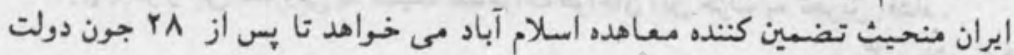

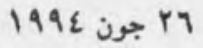
استاد ربانى را به رسميت نشناسند.

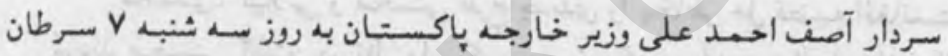

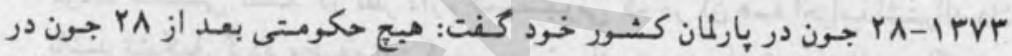

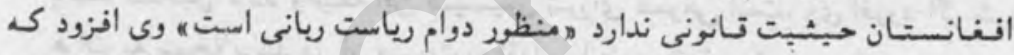

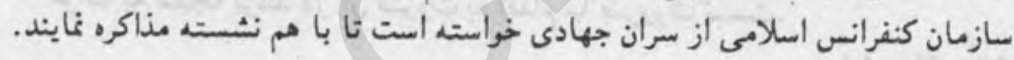

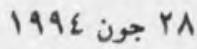

\section{$\$ 88$}

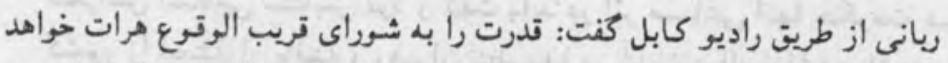

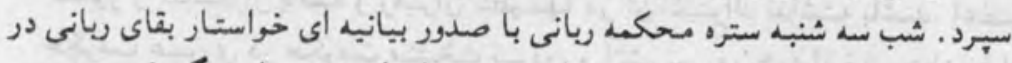

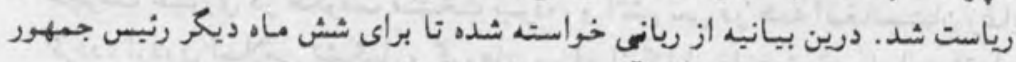

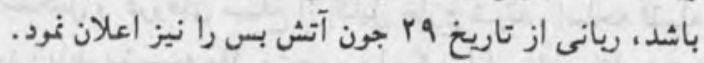

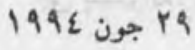

$\& \&$

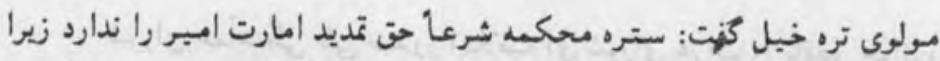

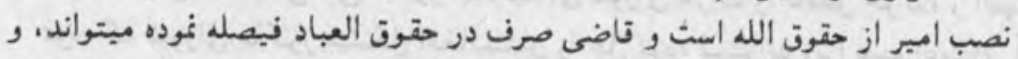

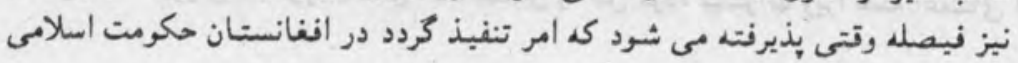




$$
\text { نيست و آنان هد كار هاى خود را بنام اسلام مى كنند. }
$$

1 جولاي 1992

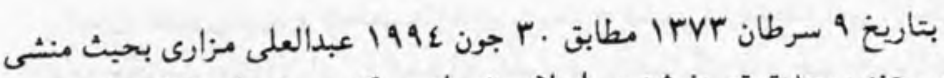

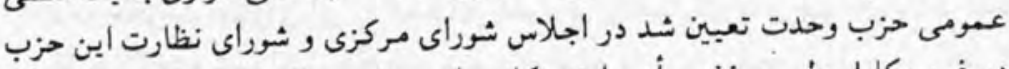

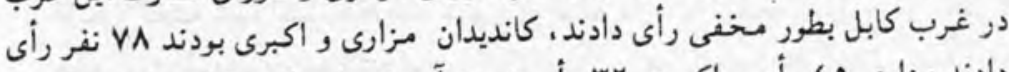

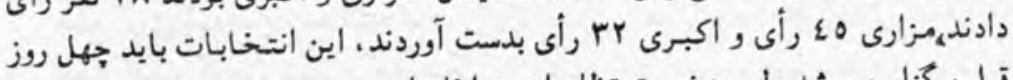

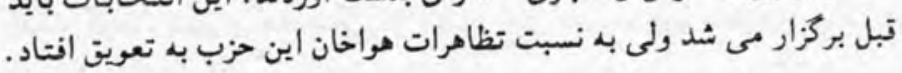
r بولاي ع 199

محمدى، كيلانى و محسنى طرح جديدى را بـاطر حل قضبم افغانستان مطرح

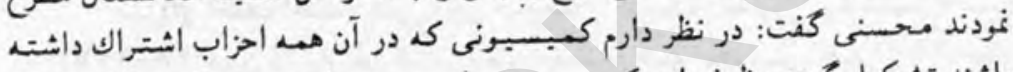

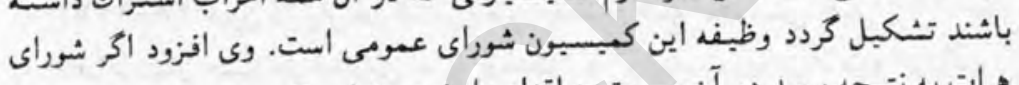

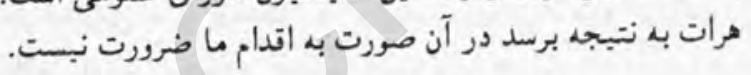

أجولاي 1992

شوراى هـآهنكى طى صدور اعلامبد ایى از تلاشهاى مؤسسه ملل و سازمان

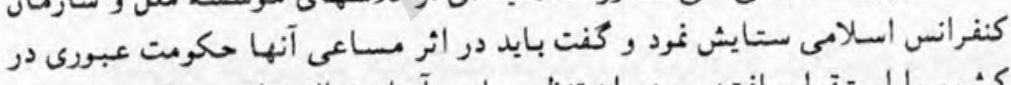

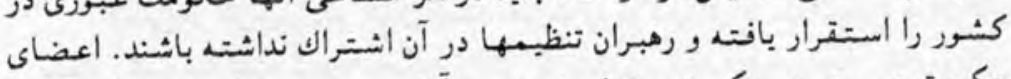

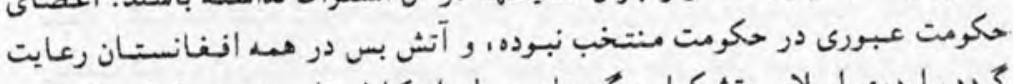

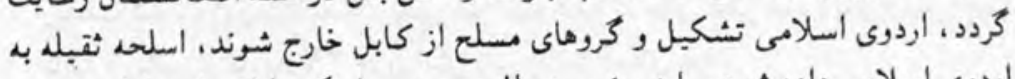

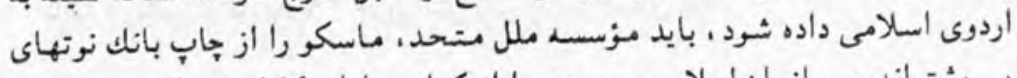

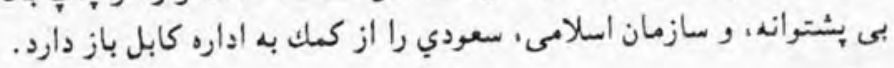
1992 ا 194

$\mathscr{8}$

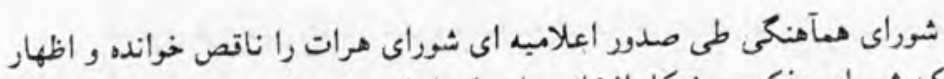

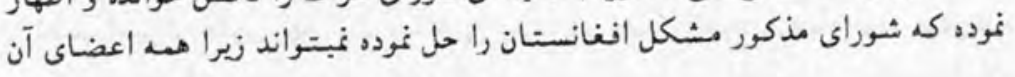




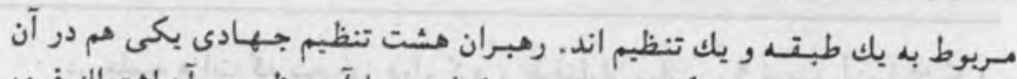

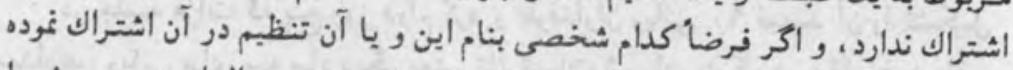

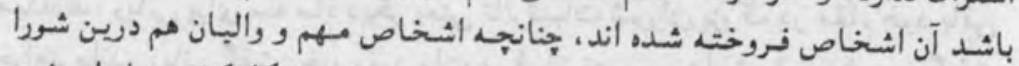

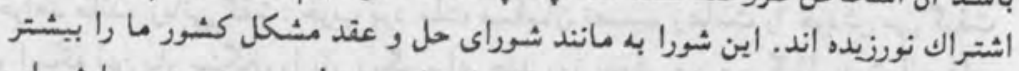

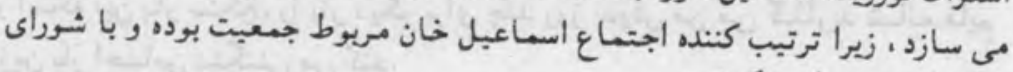

1992 هآهنكى در حال جنگ است.

$8 \% \&$.

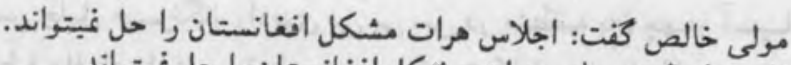

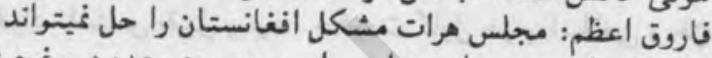

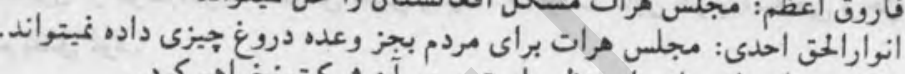

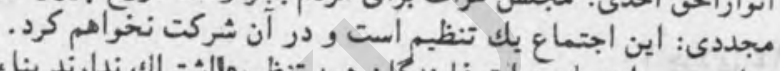

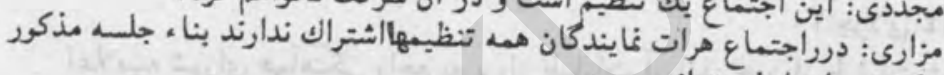

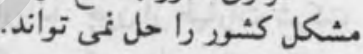

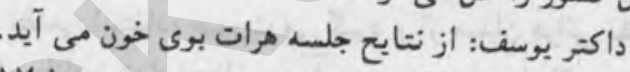

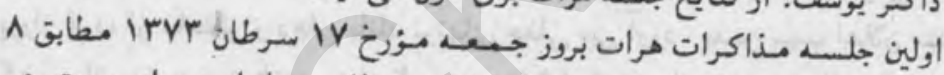

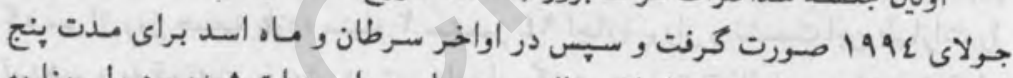

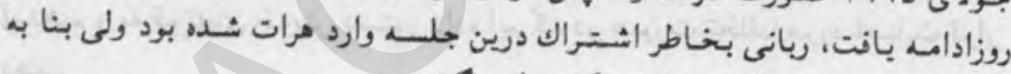

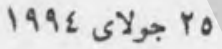
اختلافات موجود نتوانست داني داخل مكان جلسه كردد.

$8 \%$

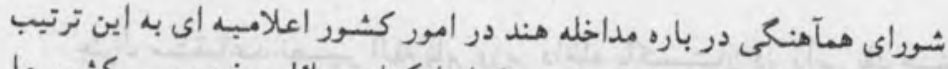

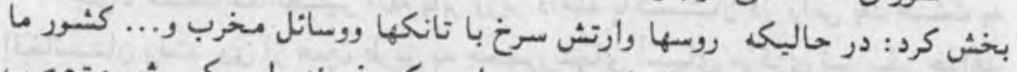

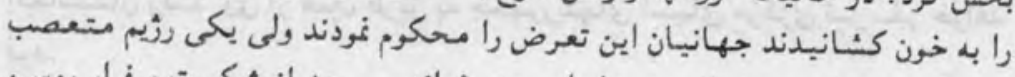

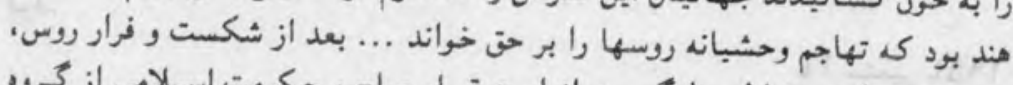

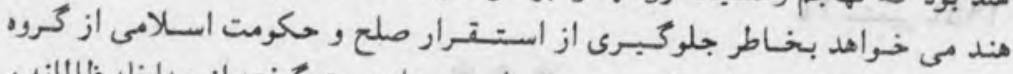

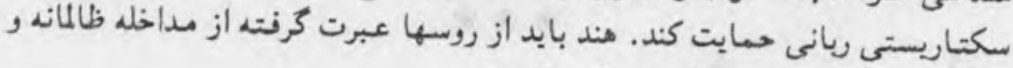

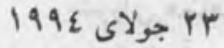

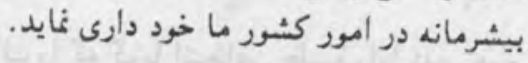




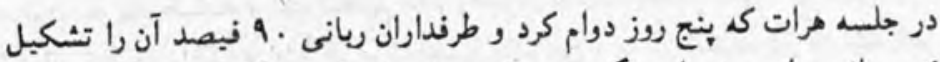

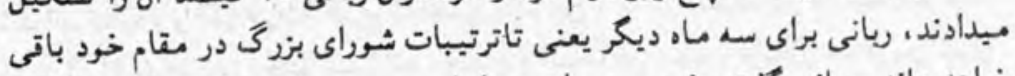

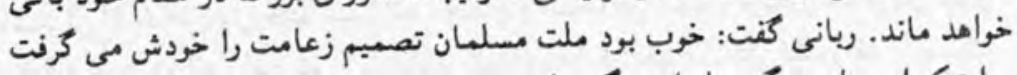

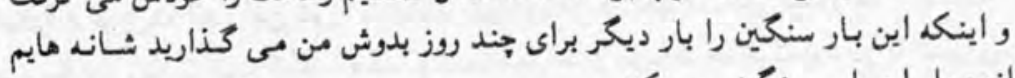
ازين بار احساس سنكينى مى كند.

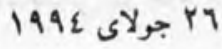

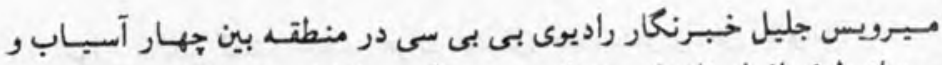

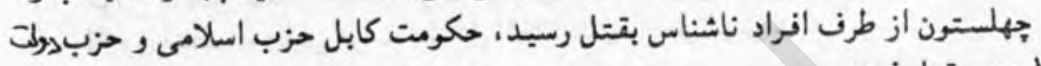
لإمتهم بتتل نمود.

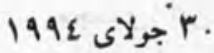

اعلاميد شوراى ههآهنحى راجع بد يرواز طيارات آريانا : جون از طبارات شركت

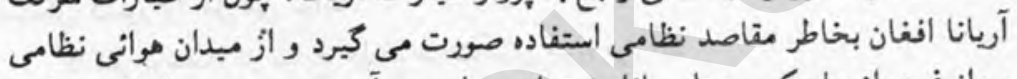

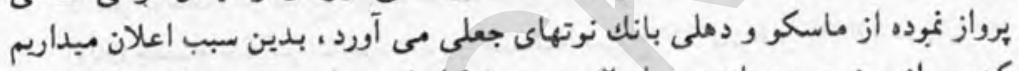

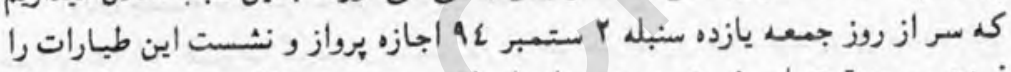

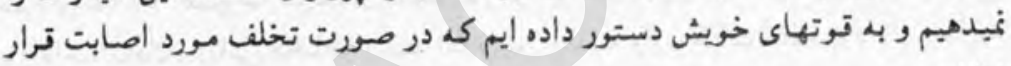

1992

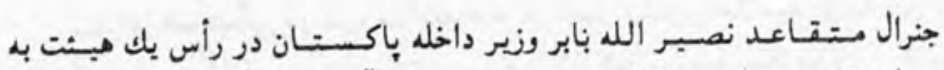

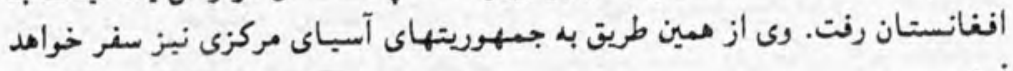

$199 \varepsilon$ r $19 \varepsilon$

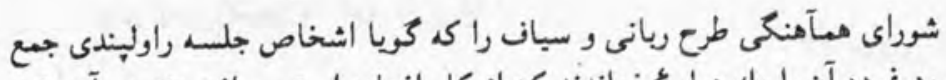

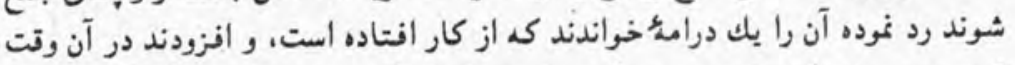

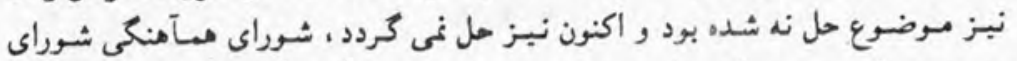

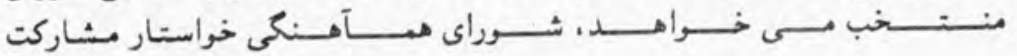


جنبش ملى در شوراى آينده نيز شد.

1992 ا اكتوبر

क क

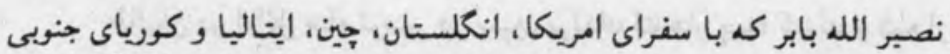

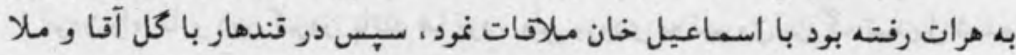

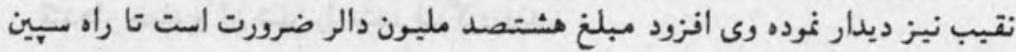
بولدك تورغندى اعمار كردد.

$199 \varepsilon$ \& 19

$\$ \$ 8$

\section{اعلاميسشورايهمآمنكى:}

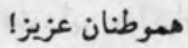

درين اواخر اداره جهنمى خاد تبليغاتى را مبنى بر جعلى بودن بانك نوتهاي درو

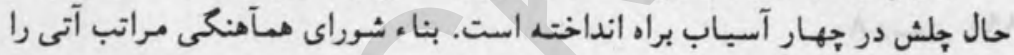
1- بجزز بانك نوتهاى بنج هزار و ده هزار افنفانيكى سـاير بانك نوتهاً تـابل

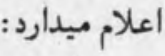

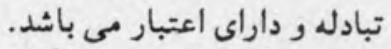

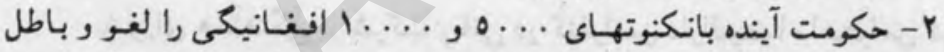

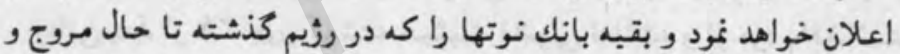

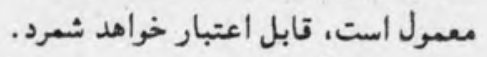

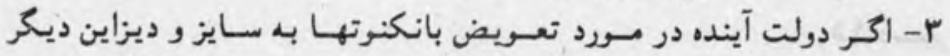

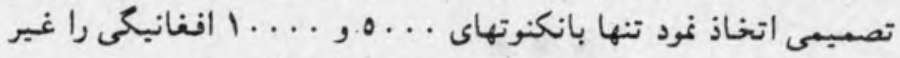

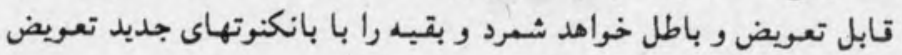

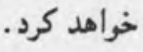

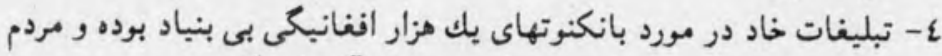

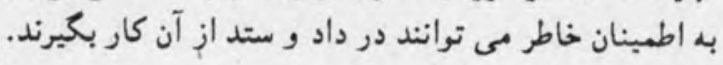
1992 نومبر 19

8818

طالبان در ا Y نومبر قندهار را متصرف شدند. مولوى خالص در باره حركت كى 
حوادث تاريخى افغانستان/ 107

از جندى قبل در قندهار بوجود آمده كفت: اكر تيام طالبان بخاطر خدا باشد آنان تنها

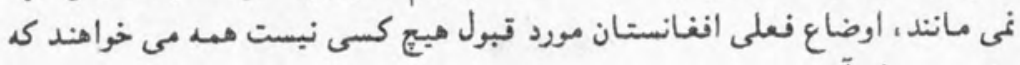

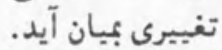

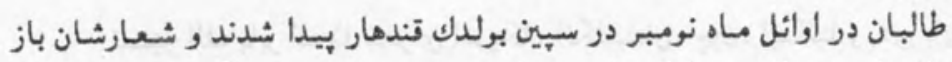

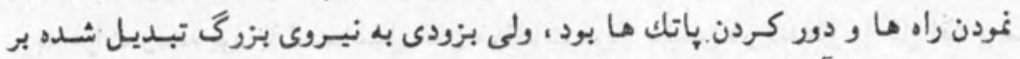

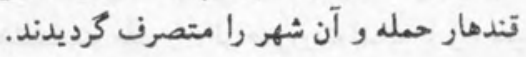

1992

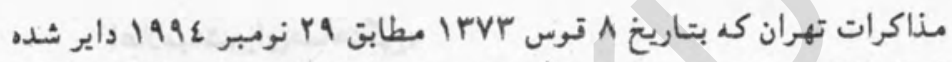

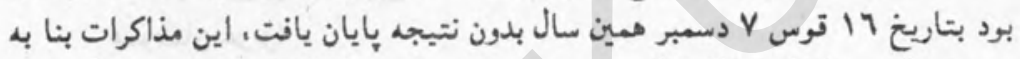

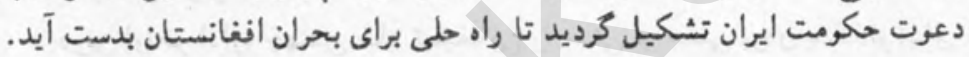
1 1992

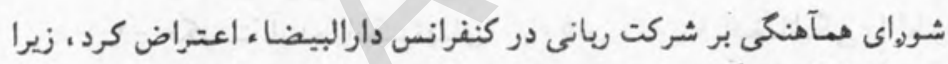

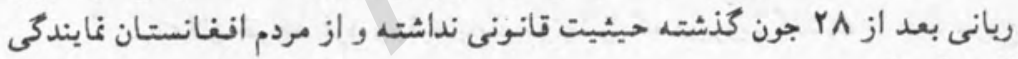
كرده نميتواند. 10 دسمبر 1992 


\section{سال 1990م}

\section{اعلاميه هينتحلع:}

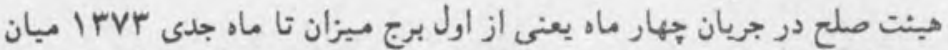

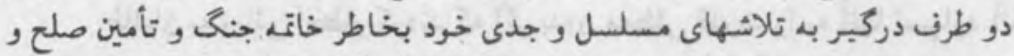

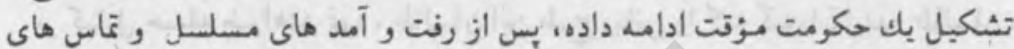

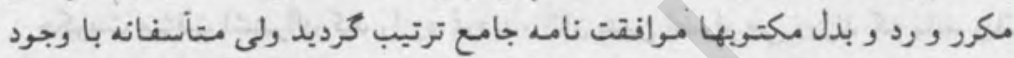

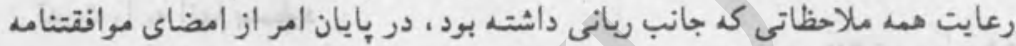

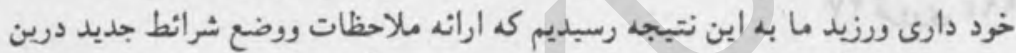

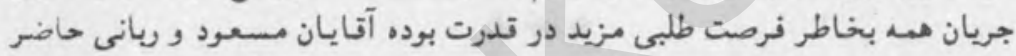

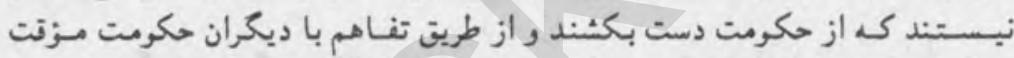

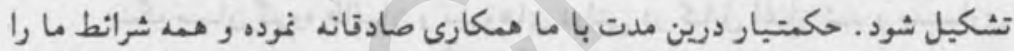

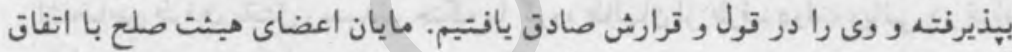

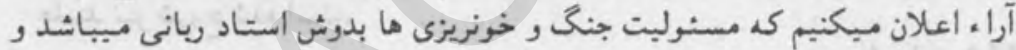

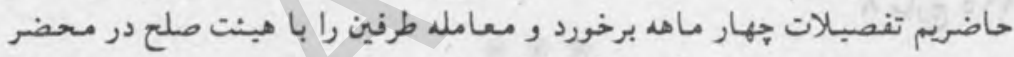

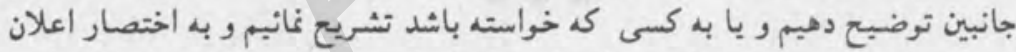

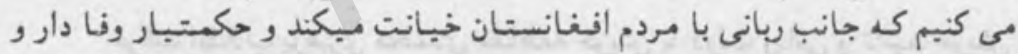

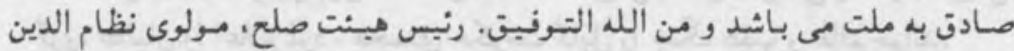
1990 19 19

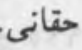

حكتيار در رابطه با جنبش طالبان كفت: حركت طالبان توطثه خارجى يكتعداد

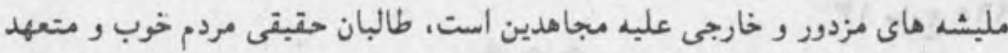

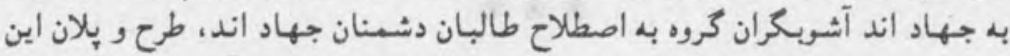

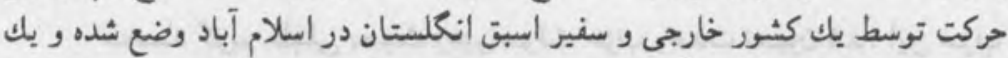

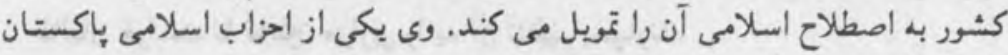

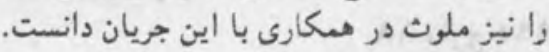




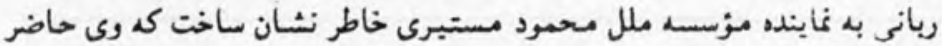

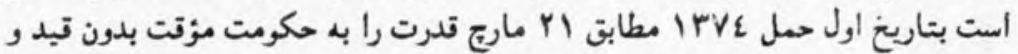

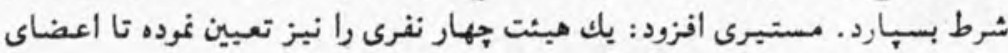
مكرمت مؤت را تعيين نمايند.

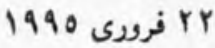

$\$ 8$

طالبان به ربانى اخطار كردند كه اخر بدون معطلى قدرت را بـ آنها نسبارد آنان

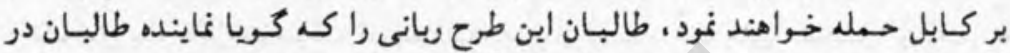

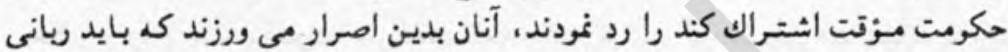

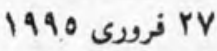
قدرت را بـ آنها بسلهرد.

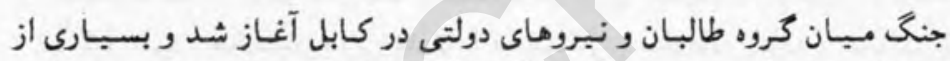

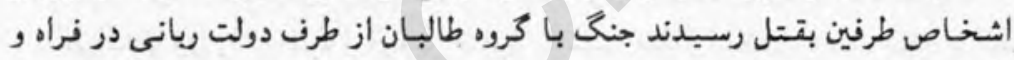

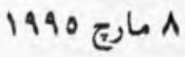

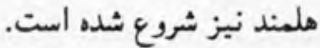

$8 \%$

حركت انقلاب برهبرى محمدى مقاطعه خويش با دولت ربانى و تاثيد خويش از راز

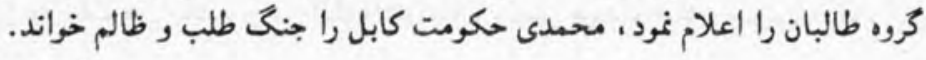

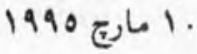

عبدالعلى مزارى رهبر حزب وحدت ذريعه كروه طالبان بقتل رسيد، در مورد قتل

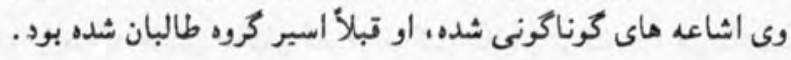

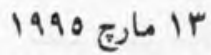

$\$ \$$

مسحمد كريم خليلى بحيث رهبر مـوقت حزب وحدت تعبين شد. اين حزب از

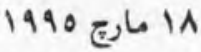
طالبان خواست تا قاتلين مزارى را به آن تنظبم بسبارند. 


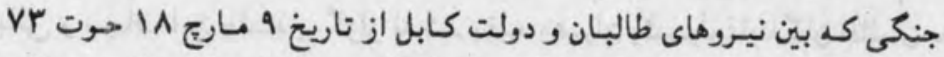

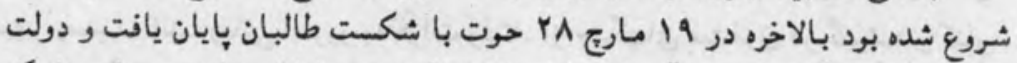

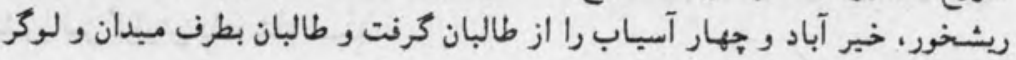

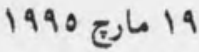
نرار نموده وره عده اي از آنان كثته شدند.

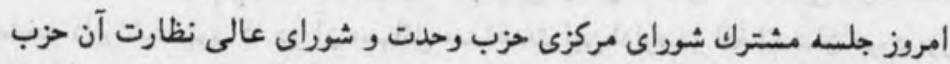

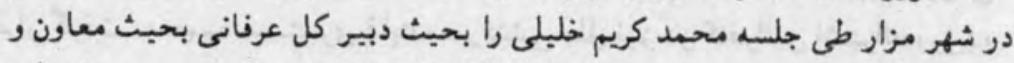

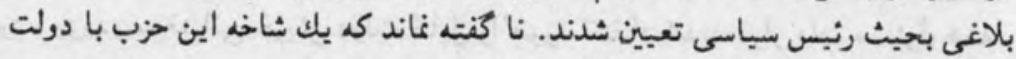

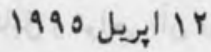

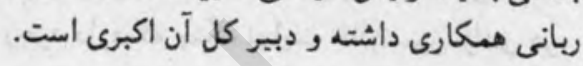

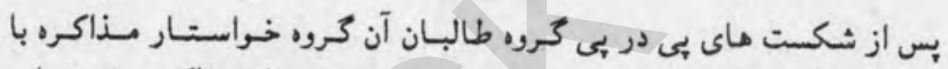

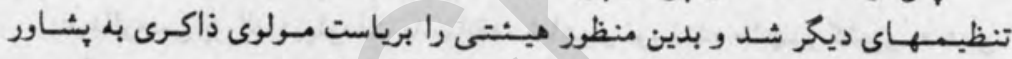
1990 14

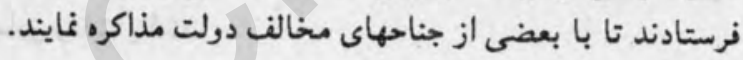

888

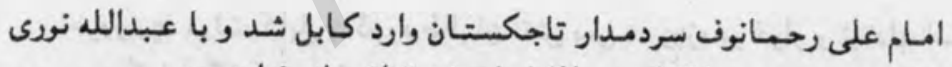

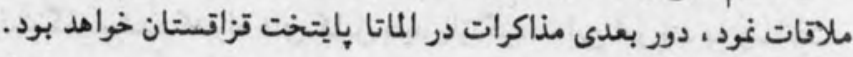
1990 19 19 19 19

در اولين ساعات صبح امروز ه شنبه 11 جوزا مولوى فضل الرحبيم ابو ادريس

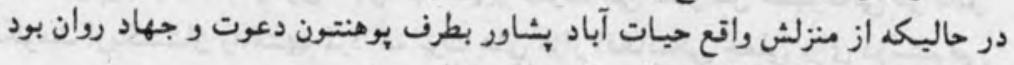

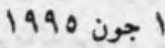
در نزديك منزلش از طرف اشخاص نا معلوم بقتل وسيد. 


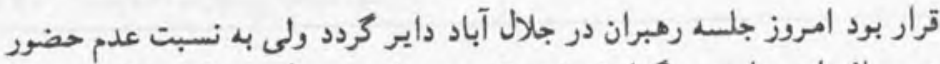

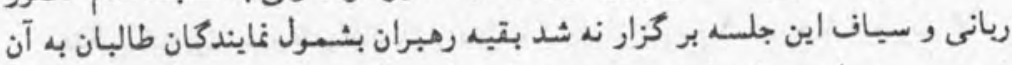

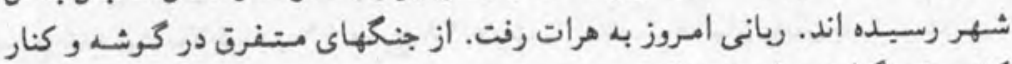

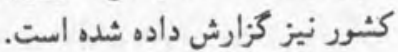

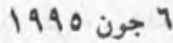

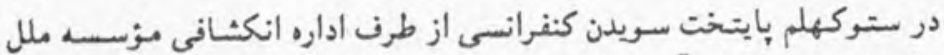

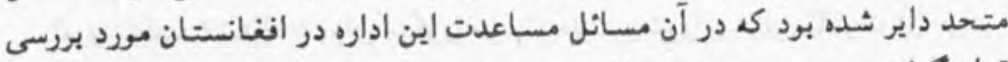

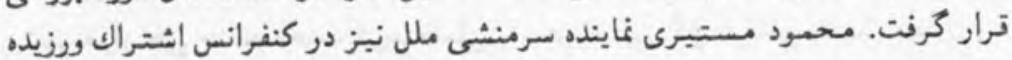

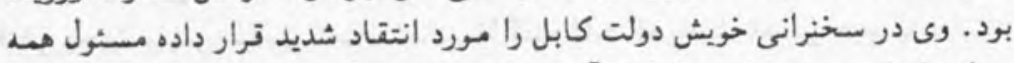

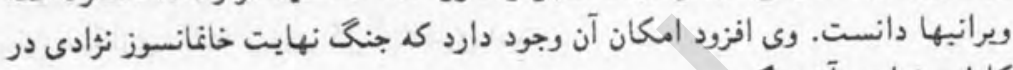
كابل و نواحى آن دركيرد. 1990 جون P

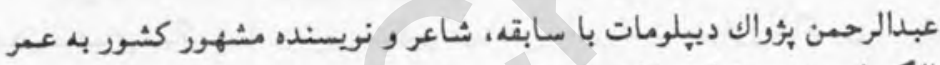
1 A سالكى امروز در بشاوز وفات يافت.

19 1990

$\mathscr{8} \&$

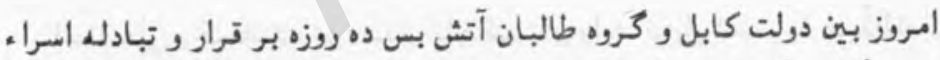

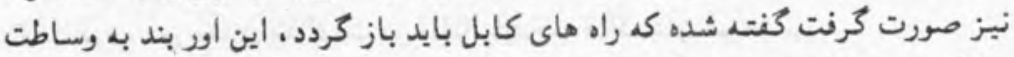

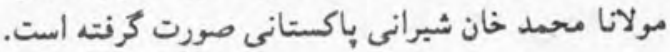

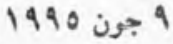

سر برست بانك مركزى كابل عبدالقدير نطرت طى كنفرانس مطبوعاتى در كابلز.

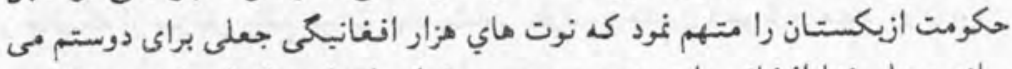

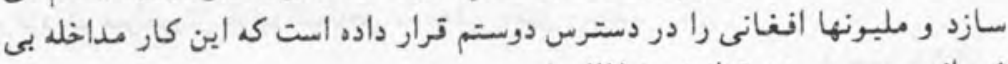
شرماند بوده و بر ضد توانين بين المللى است. 
دوستم همجِو اتهامات را بى اساس خوانده و رد مى كند.

1990 اجون 19

क \& 8

حكومت كابل بخاطر خوشى خاطر طالبان امروز شش نفر طالب اسير را آزاد

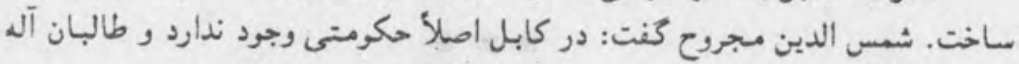

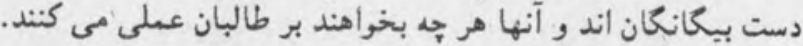

1990 11

هينت بارلمانى روسبه كه روز قبل وارد كابل شده بودند امروز به ماسكو رنتيند،

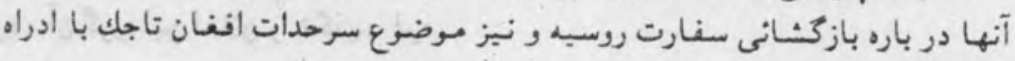
19 1990

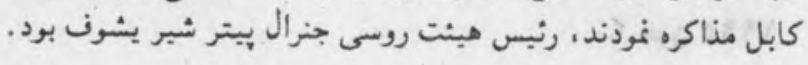

ஜ ஜ \&

بنا به كفته ملا خبـر الله نماينده طالبان امروز اوربند بين طالبان و اداره كابل

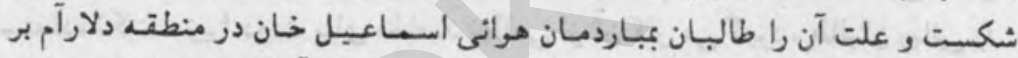

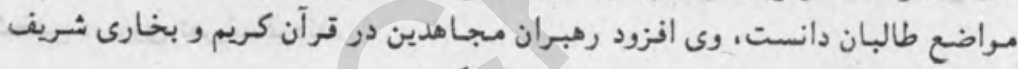

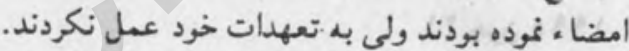

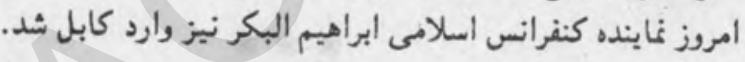

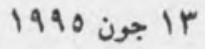

\& 8

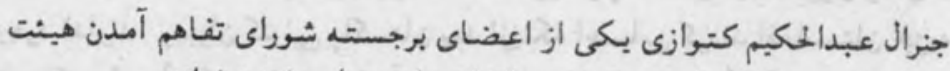

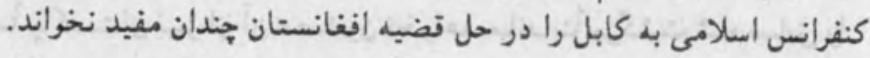

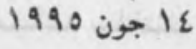

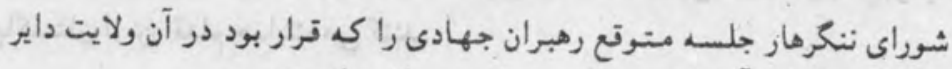
شود فسخ نمود ور علت آن را عدم حضور سباف ورع ريانى دانست.

1990 10 


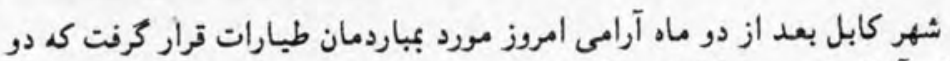

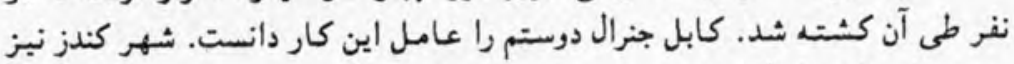

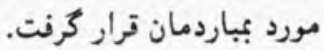

1990 19 190

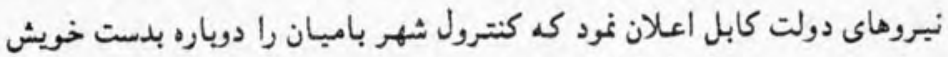

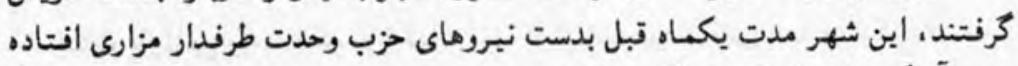
بود. آن كروه اين اعلان را نكذيب نمود.

1990 بون r.

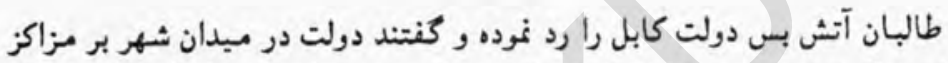

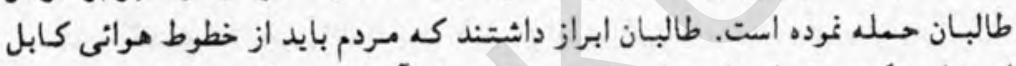

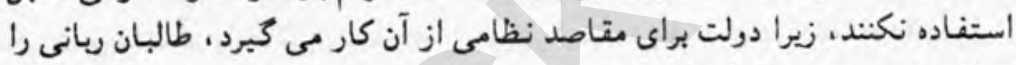
شخض دو روى تعريف نودند.

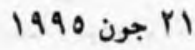

$\$ 2 \%$

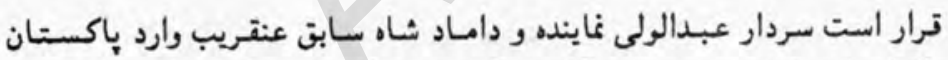

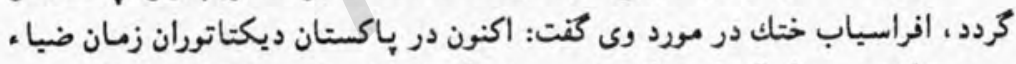

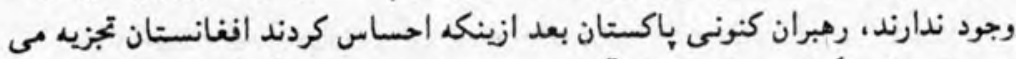

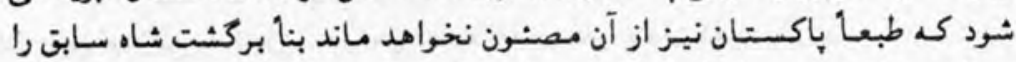

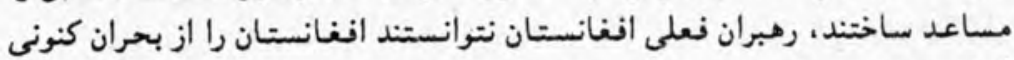

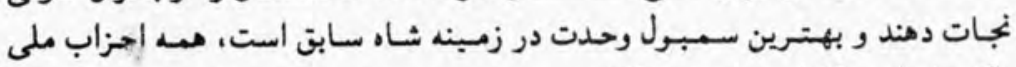
باكستان ازين اقدام حمايت مى كنيند.

1990 T TV

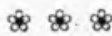

ظهر امســروز سردار عبدالولى وارد اسلام آباد شد در ميدان هوانى اسلام آباد

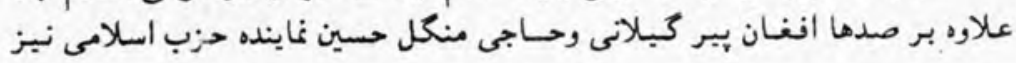




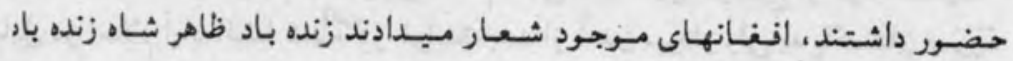

199 1990 افغنانستان.

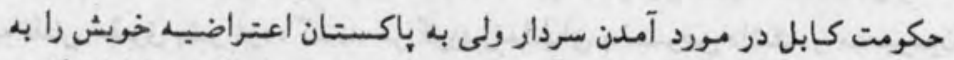

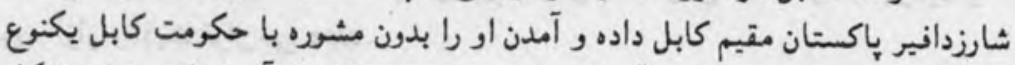

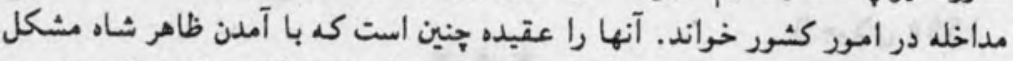

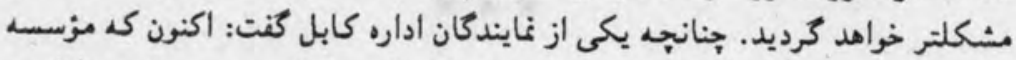

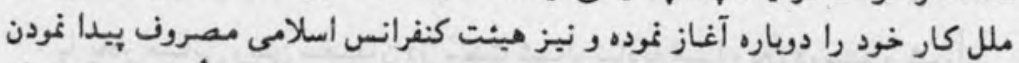

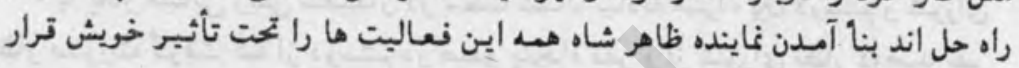

Y بولاى 1990 مى دهد.

$8 \%$

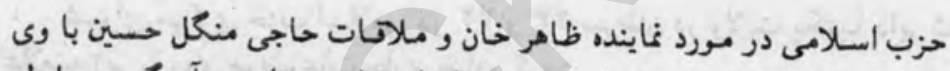

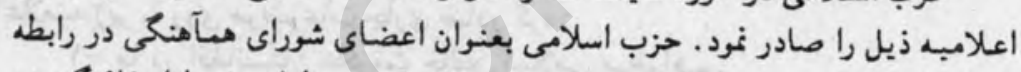

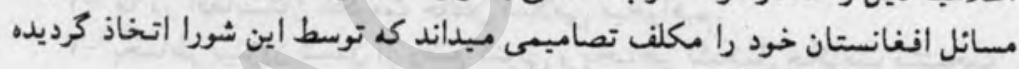

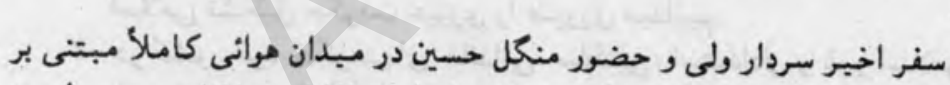

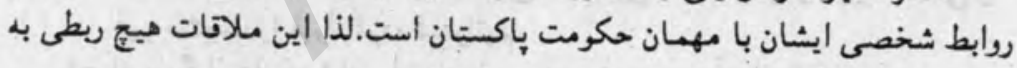
ع ألاى 1990 بالبسى حزب ندارد.

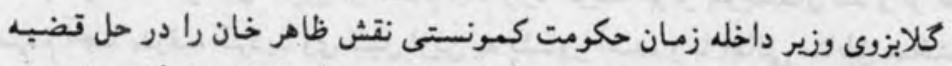

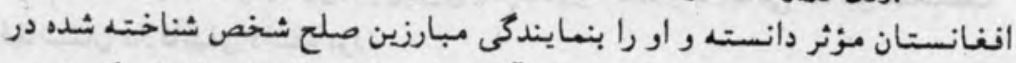

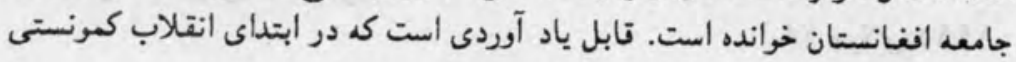

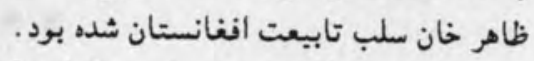

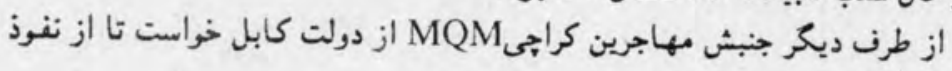


حوادث تاريخى افنانستان/ 1 ح

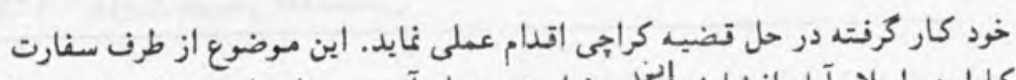

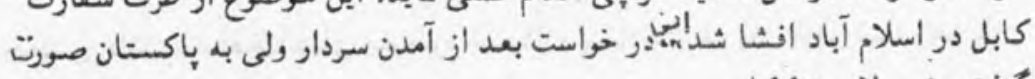
كرنت.

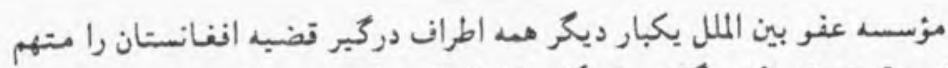

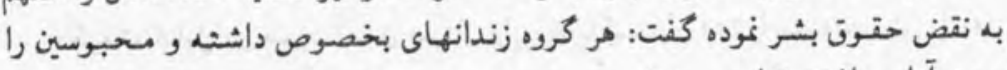
مورد آزار و اذيت قرار مى دهند.

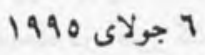

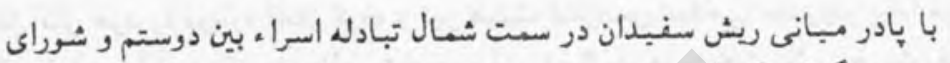

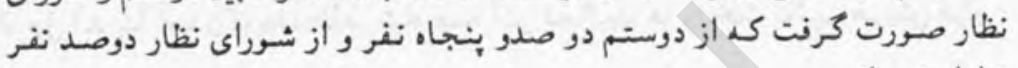
تبادله شده اند. ت مسروت

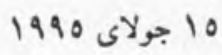

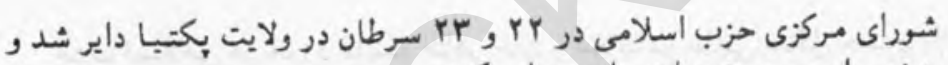

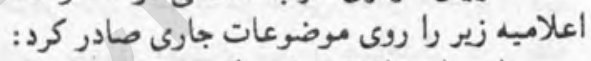

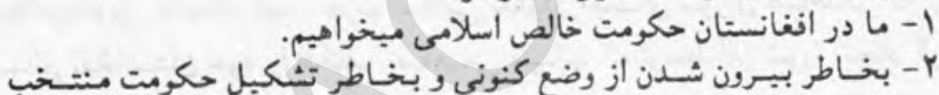

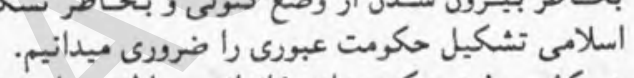

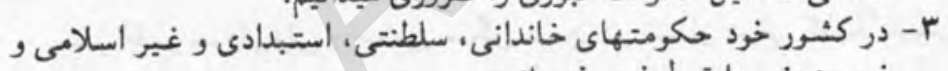

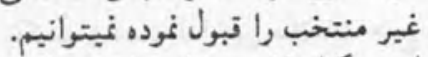

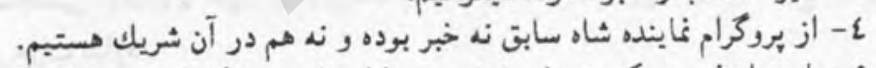

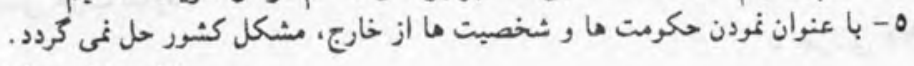

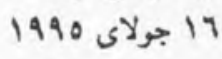

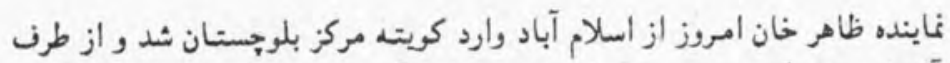

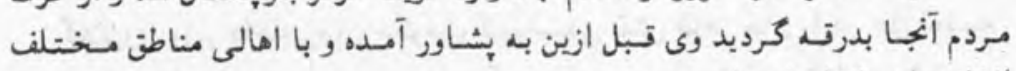
انغانستان ملاقاتهاى داشته بود بودي

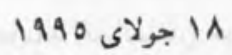




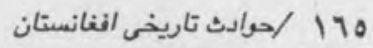

جهارمين دور كرثش هاى محمود مستيرى شروع شد وى از اسلام آباد به جلال

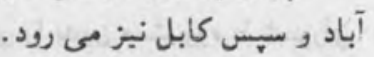

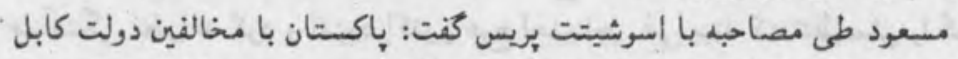

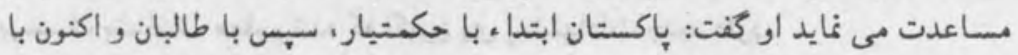

سردار ولى مساعدت مى كند.

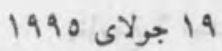

هيثت سازمان كنفرانس اسلامى وارد كابل شد تا با رهبران جهادى مذاكره نمايد.

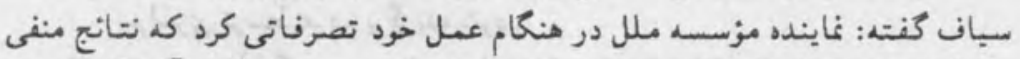

بجا كذاشت، وى ابتدا خواهان تطع مداخلات خارجى سبس ميانجكرى آنها كرديد.

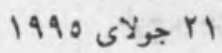

بنا بـ كزارش راديوى كابـل هند آمـادكى خهود را در سـاختن بند برت در منطقد

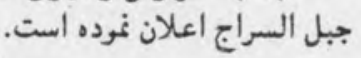

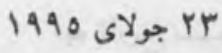

مستيرى روز خنجشنبه با جنرال دوستم ملاقات نمود .

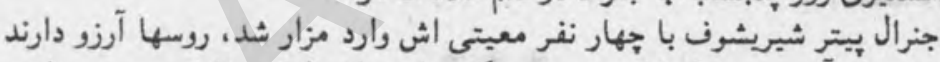

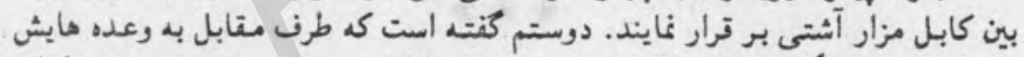

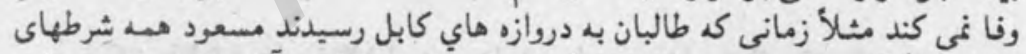

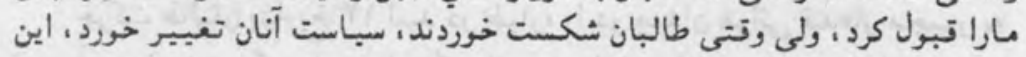

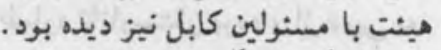

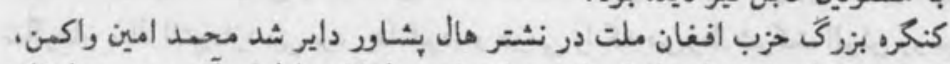

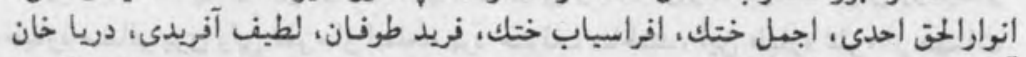

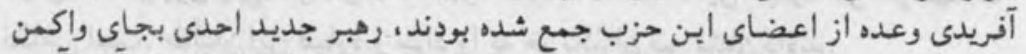

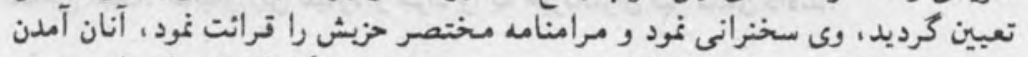

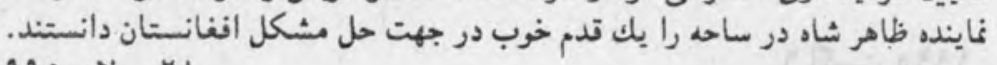

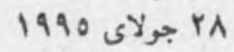




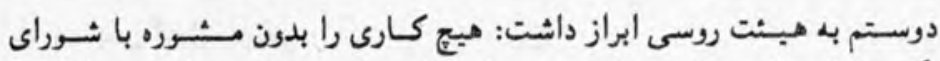

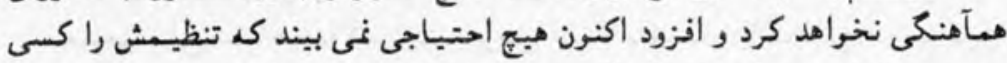

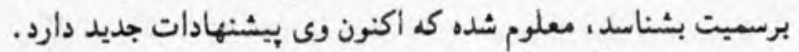

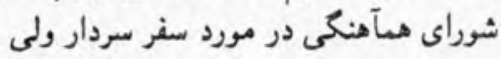

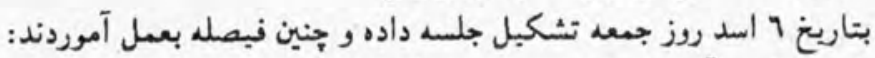

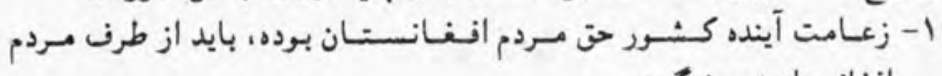
انغانستان تعيين كردد.

r r- نظام آينده كشور يك نظام منتخب اسلامى بردوده برد اساس انتخابات آزاد و سراسرى توسط مردم بركزيده شوده.

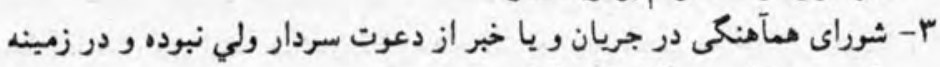

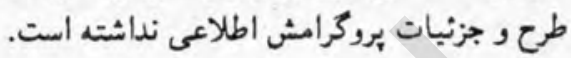

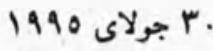

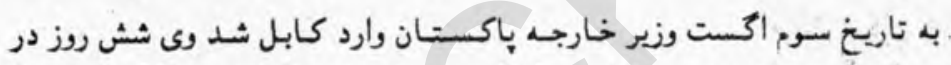

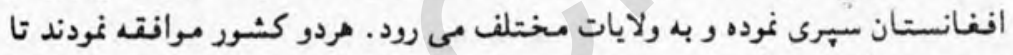

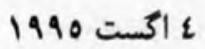

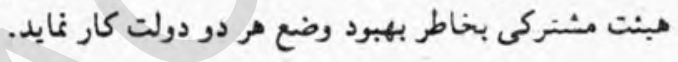

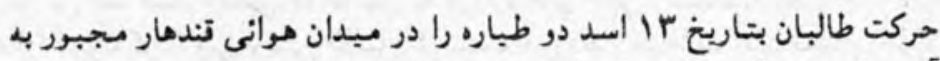

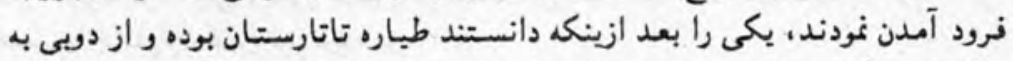

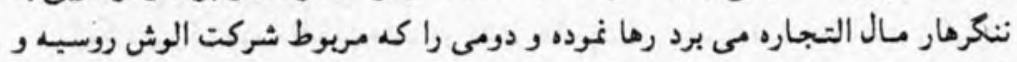

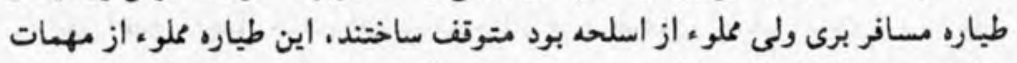

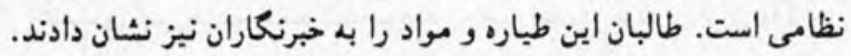

1990 19

حكومت كابل اعتراف نمود كه طباره كاركوى روسى را كرايه نوده و از البانبا

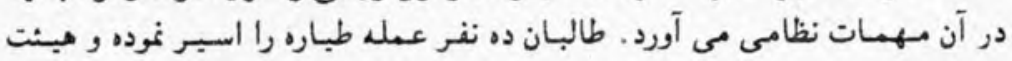


1990 11

روسى بدين منظور بكابل رسيده است.

$\$ 8 \&$

شب كذشته تقريبا در حدود سى راكت بر مناطق مسكونى كارته سه اصابت نمود

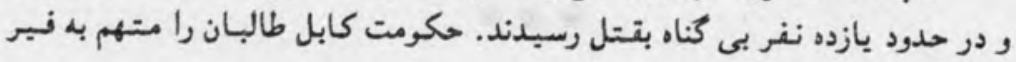

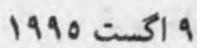
راكت نمود.

$\$ \&$

طالبان در مورد رهائى اسبران روسى خواهان رهائى شصت هزار نفرى شدند كرند

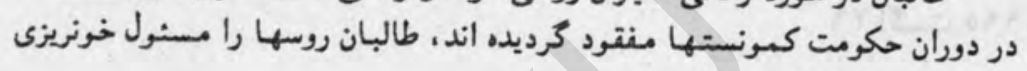

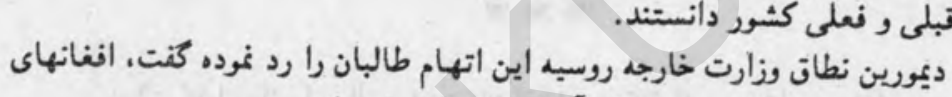

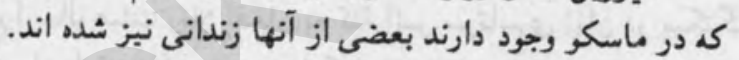

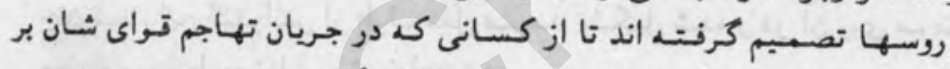
1990 10 افنانستان در بهلوى شان ايستاده بودند ، دفاع حقوقى كنيند.

$\$ 8$

رهبر حزب ناسبيونالست روسيه اظهار داشته كم بخاطر رهانى بيلوتان روسى $1990=3119$ دست بكار خوأهد شد.

$\$ \&$

كابل شب كذشته هدف . ب نير راكت ترار كرفت ب نفر كثته و عده اى كثيرى

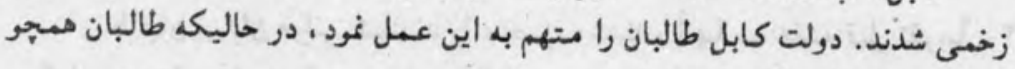

1990 198

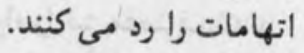

علا عالدين بروجردى معاون وزارت خارجه ايران وارد كابل شد، وى ميخراهد با مأبا 19400 1 إكست رهبران تنظيـهاى جهادى مذاكرن نمايد. 
حوادث تاريخى افغانستان/ 141

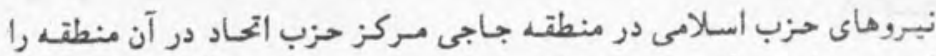

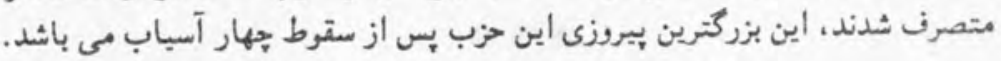

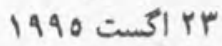

كريم خليلمى رهبر حزب وحدت از ملاقات با آتاى أبراهبسى غناينده رهبر مذهبـ

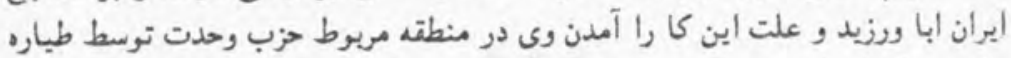

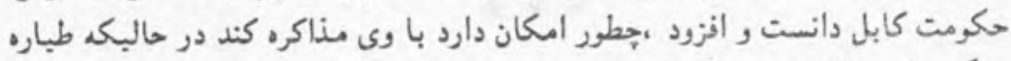

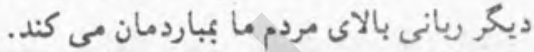

1990 190

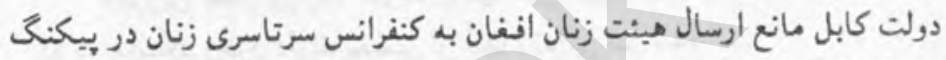

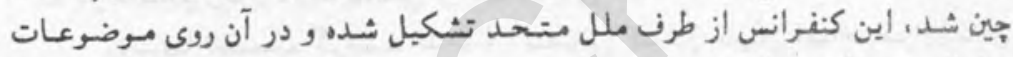

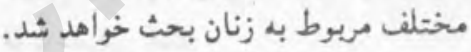

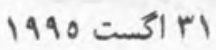

$8 \%$

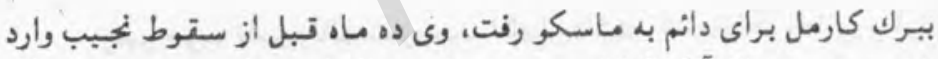

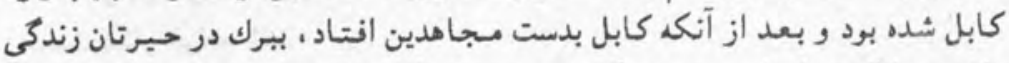

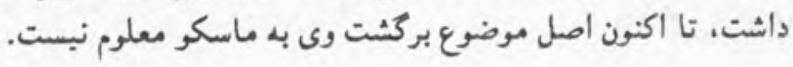

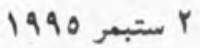

$8 \%$

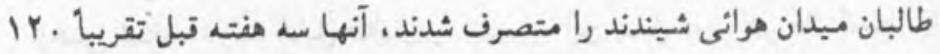

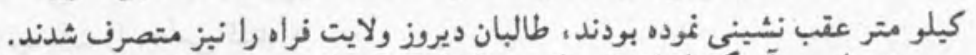

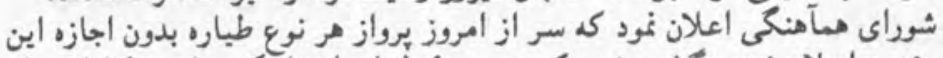

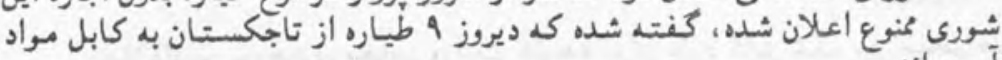

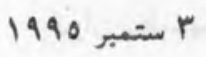




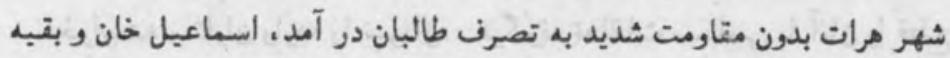

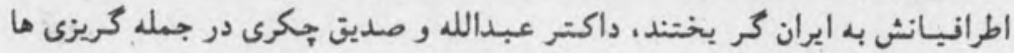

مؤسسه ملل متحد كاركنان خود را از هرات بيرون نمود ، دولت كابل استخبارات

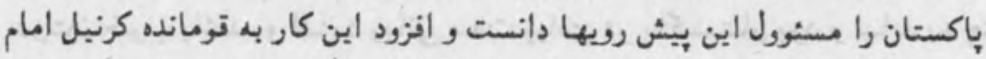

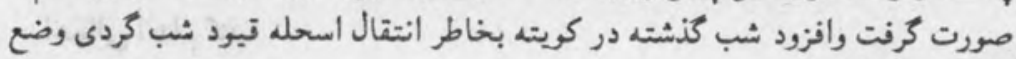
ع 1990 ستمبر شده بود.

88

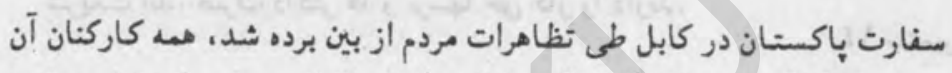

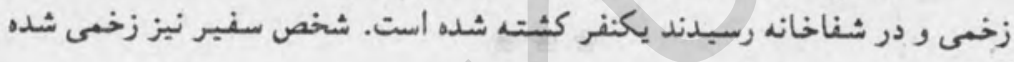
است.

متعبر 1990

$$
\text { از طرف ديكر ايران سرحد خود با افغانستان را مسدود نمود. }
$$

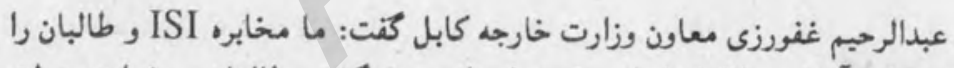

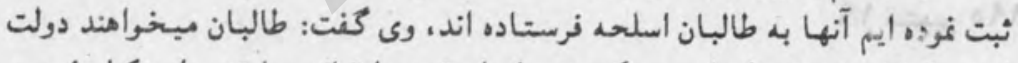

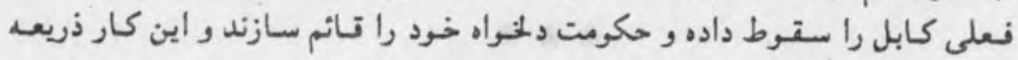

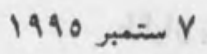

$$
\text { باكستان صورت مى كيرد. }
$$

838

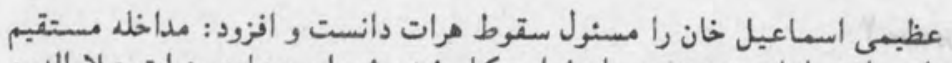

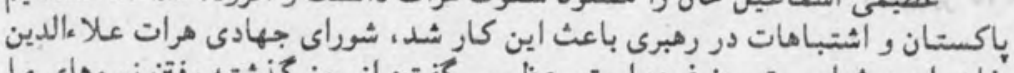

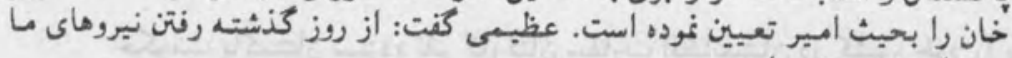
1990 ستمبر 19 


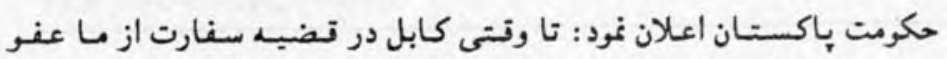

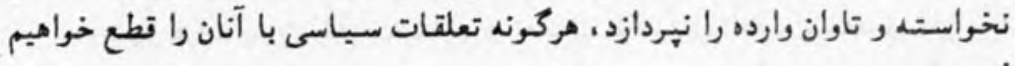
نود. بى نظير بوتو كفت: ما روابط خود با كابل را تطع نى كنيم بلكه سفارت خود

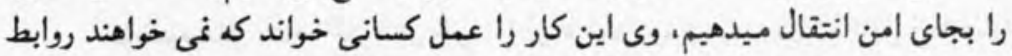

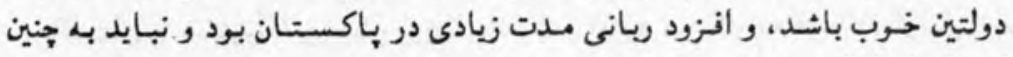

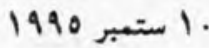

طالبان در هرات مانع رنتن زنان به مكاتب و دفاتر شدند ، طالبان خواهان اجراى 1990 18

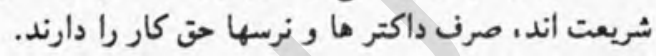

حكومت كابل اعلان نمود تا وقتسى با طالبـان مـاكره نمى كند كـه آنان دوباره

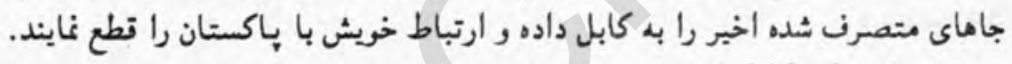

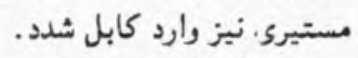
قبلاً طالبان اعلان نموده بودند كم ربانى و مسعود بايد بدون تبد و سرط به آنها تسليم شوند. 1990 19 19

$\& \& 8$

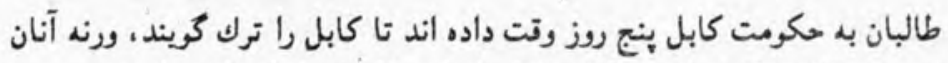

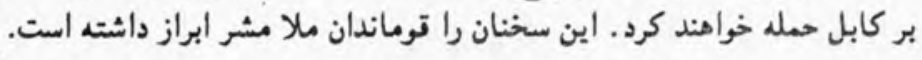

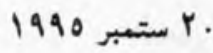

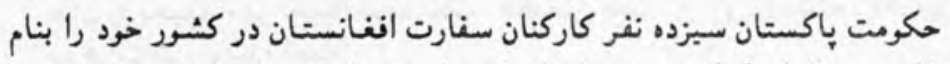

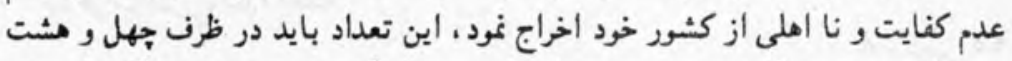

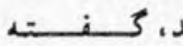
3 كرك أن

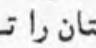


شده كه مده اين افراد مربوط تنظيم جسيت بوده اند.

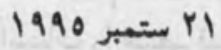

$\& \&$

مزٔسسه عفو بين المللى امنستى انترنشنل از طالبان خواست بخاطر مردم بى كناه

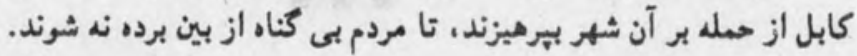
1990 To

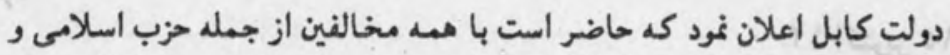

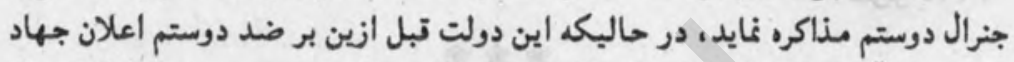

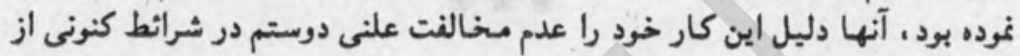
1990 rV دولت دانستند.

$\& \&$

حزب اسلامى و دوستم هر نوع مذاكره با دولت را رد نمودند و از راز ربانى خواستند 1990 199

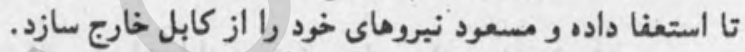
$\notin \approx$

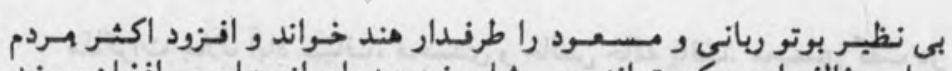

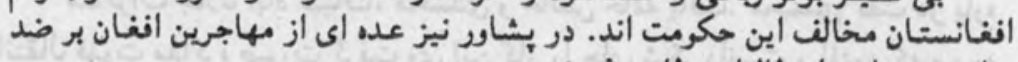
1940 ir ربانى ور حايت از طالبان مظاهره نمودند.

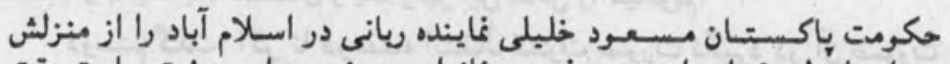

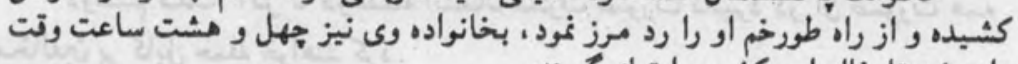

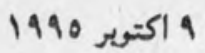
واده شد تا خاك اين كشور را را ترك كريند. 
شام كذشته طالبان حمله بر كابل را شروع نمودند ور در ساعات اول جنى جهار

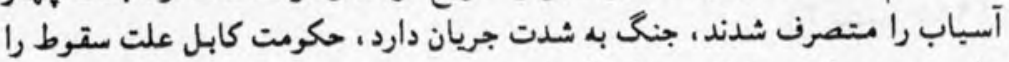

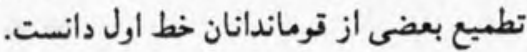

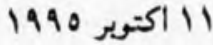

حكومت باكستان از دولت كابل مبلغ بانزده مليون دالر بخاطر ترمبيم سفارت

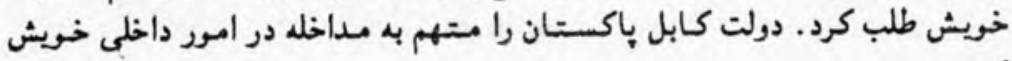
نمود. 1990 14 إكتوبر

طالبان با شوراى همآهنكى توافتى نمودند تا بر كابل يكجا حهله كنتد، احتمال

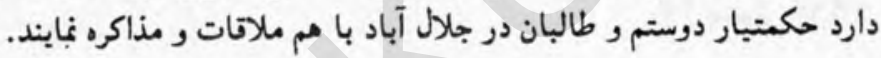

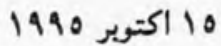

$\& \& 8$

حزب وحدت خليلى شهر بامبان را از دست نيروهاى دولتى متصرن شد.

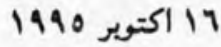

مذاكرات جلال آباد سباف، محمددى و خالص خاتهد يافت. محهمدى كفت در باره

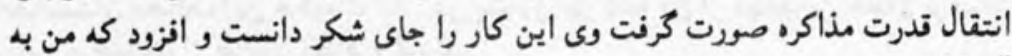

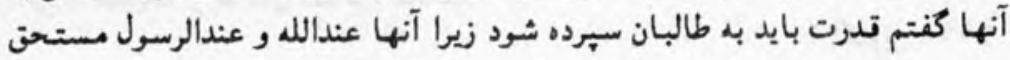

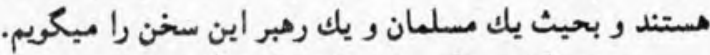

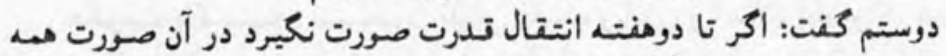
مخالفين بر كابل حمله خواهند كرد.

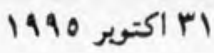

وزير خارجه باكستان آصف احمد على بنابه دعوت دوستم وارد مزار شريف شده 
با وى ملاتات نمود، حكومت كابل در جريان ترار ندارد و كفته شده كه تاضى مهايون

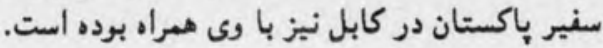

1 1990

$\$ \$$

بروجردى با ربانى و دوستم ملاحتات نمود. ملا عمر رهبر طالبان اين ملاقات رات

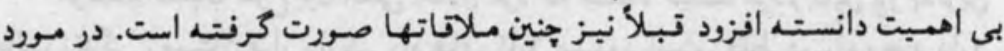

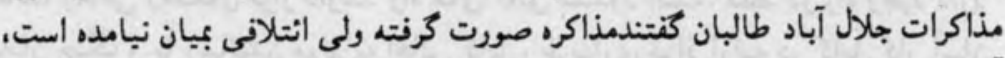

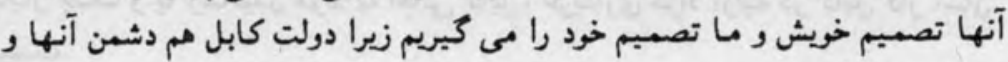

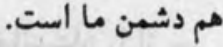

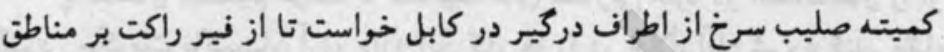

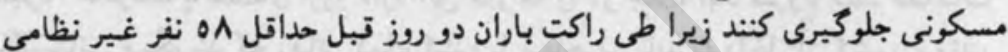

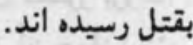

10

$\$ \& 8$

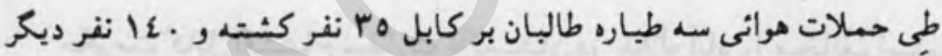

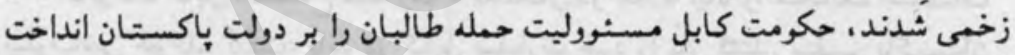
كفت نزد ما اسناد وجود دارد كد باكستان با طالبان كمك مى كند.

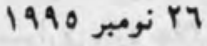

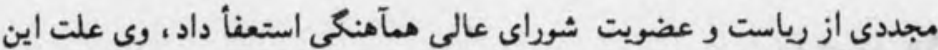

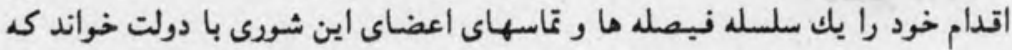

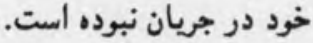

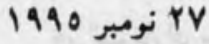

$\$ \& 8$

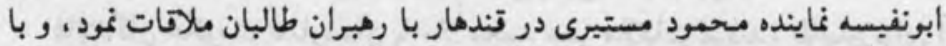

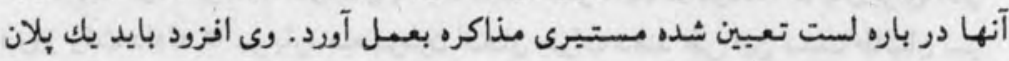


عملى روى دست گرنته شود. جنانجه خواستار وضاهت بلان جنكى عمليات كنونى

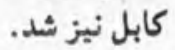

1990 Y نومبر

के \&

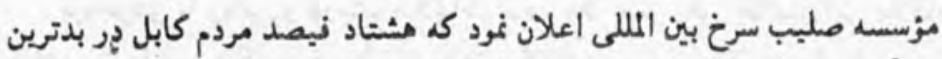

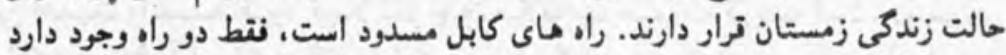

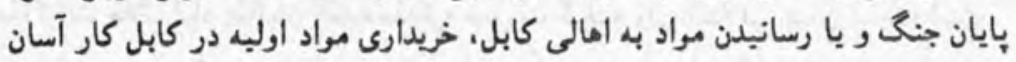

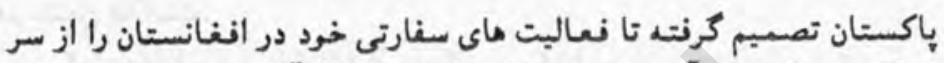

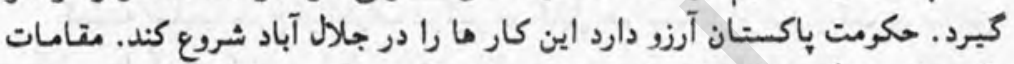

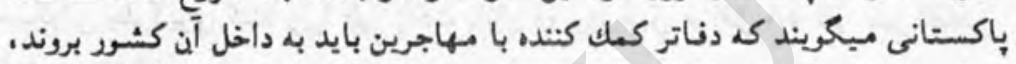

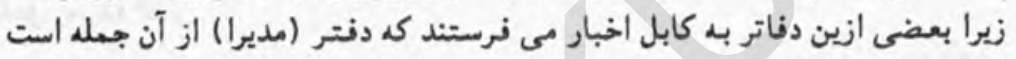

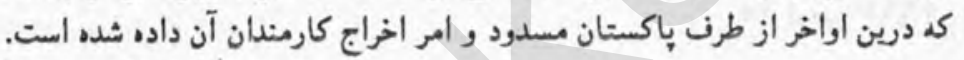
V

$\& \%$

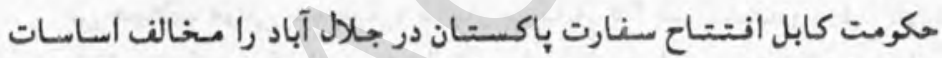

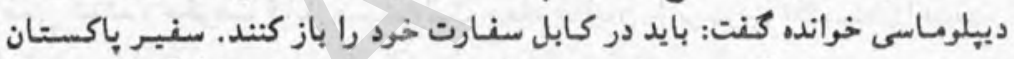

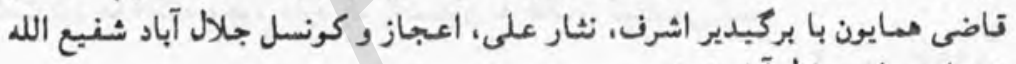

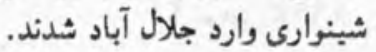

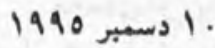

در نيويارك مقر مؤسسه ملل متحد بين نمايندكان حكومات كابل مابل و اسلام آباد

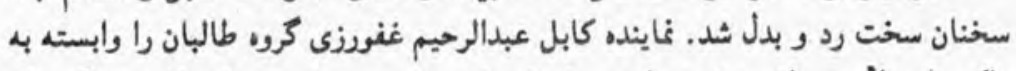

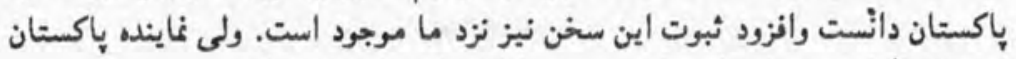

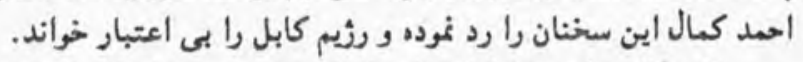

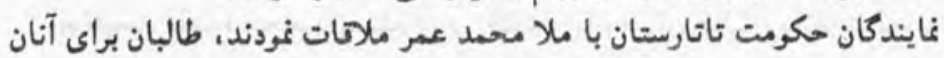

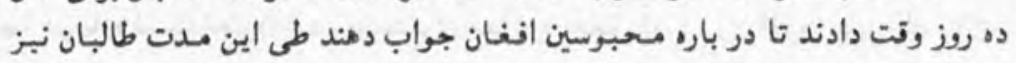


1990 190 د 19.

جواب اخير خود را خواهند داد.

جنگ بين كروه طالبان و حكرمت كابل جريان دارد، طالبان يك طباره جانب

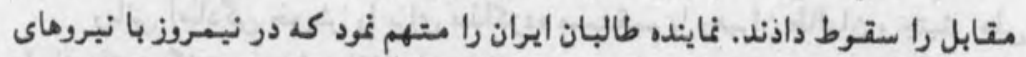

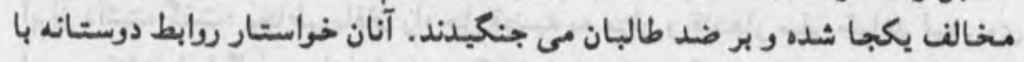

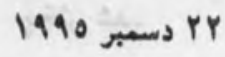
ايران كرديدند. $\$ 8$

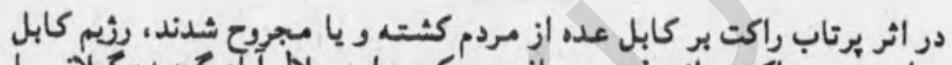

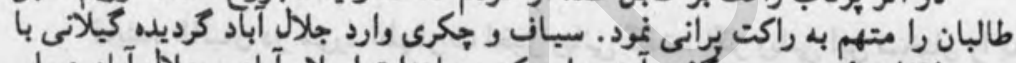

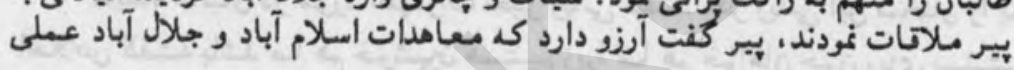

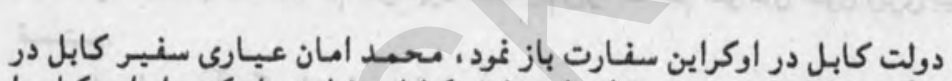

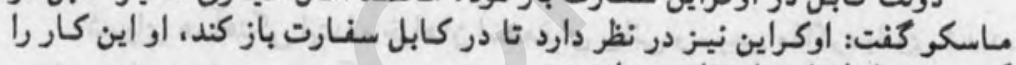
1990 Pr

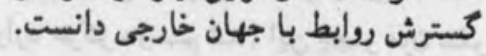

\&

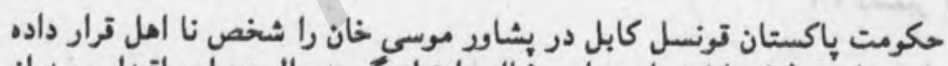

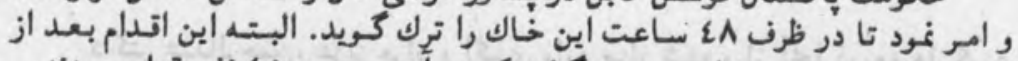

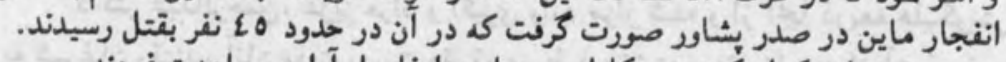

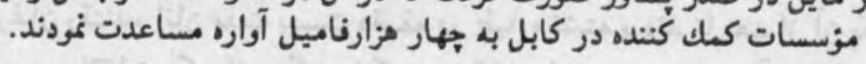

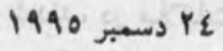

$\$ \$$

در اثر يرتاب راكت حد اقل هفت نفر در كابل بقتل رسبدند ور يازده نفر ديكر 1990 To

$$
\text { مجروح كرديدند. دولت كابل طالبان را متهم بـ اين اين عمل نمود. }
$$


IVY حوادث تاريخى افغانستان/

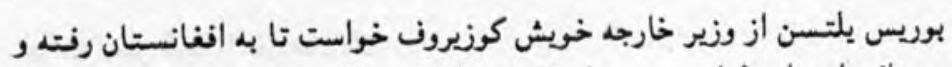
در باره رهائى اسيران طياره روسى با مقامات طالبان مذاكره نمايد. 1990 ST PV

$\$ \&$

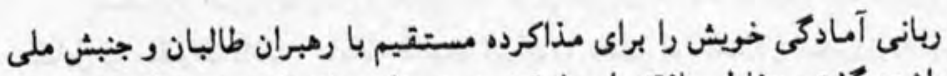

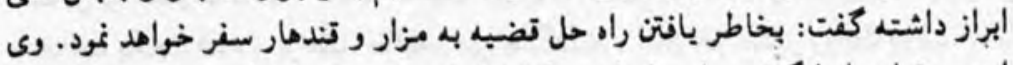

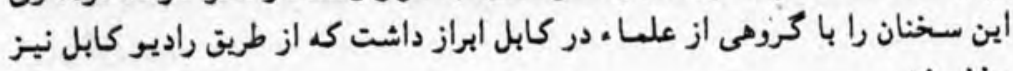
بخش شد.

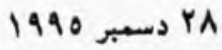

ناينده طالبان در مورد اظهارات اخير ربانى كفت: اكر ربانى اين سخنان را بـ في

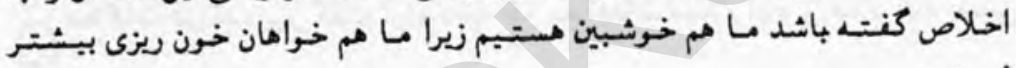

شوراى هـآهنكى ابتداء خواهان استعناى ريانى و سبس مذاكره با ورى شـدند.

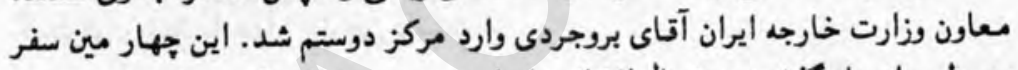

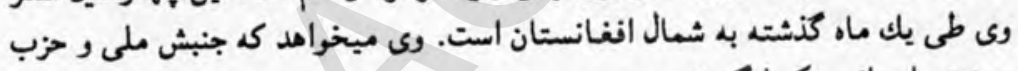
وحدت با رباني يكجا مردند. 1990 199

داكتر عبدالرحمن، عزيز مراد و اكبرى وارد مزار شده و از آنجا ذريعه هليكويتر

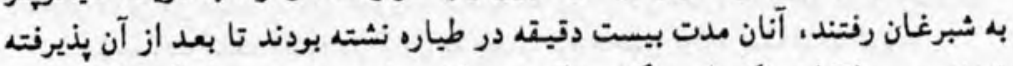

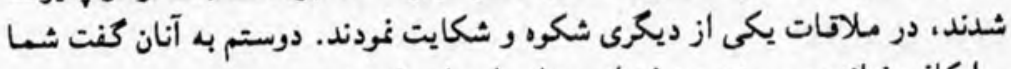

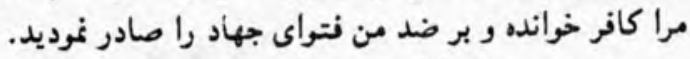

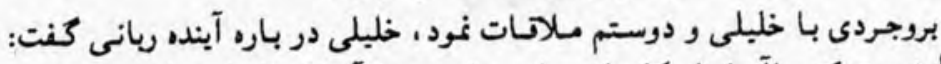

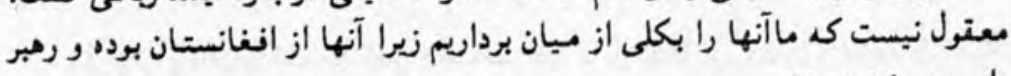
يك حزب نيز مستند.

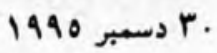


/ هوادث تاريخى افغانستان IVY

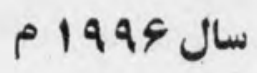

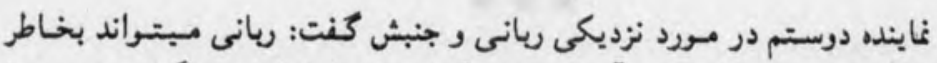

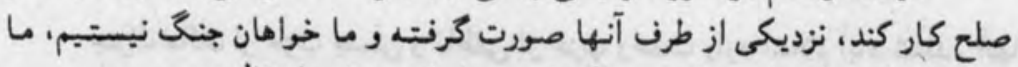

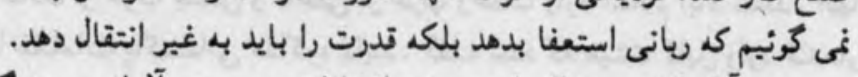

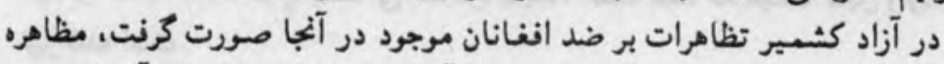

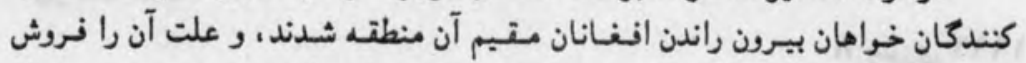

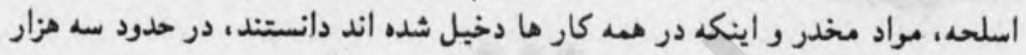
نفر افغان در منطقه مذكور زندكى دارند. 1997 جنورى

در اثر فبر راكت در حدود بيست نفر كشته و عده اي زخمى شدند ، اين راكتها

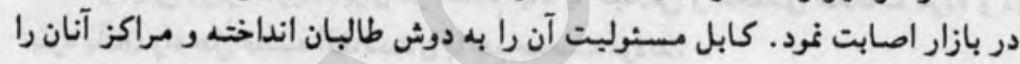

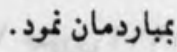

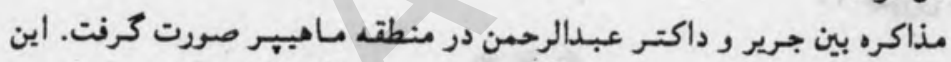

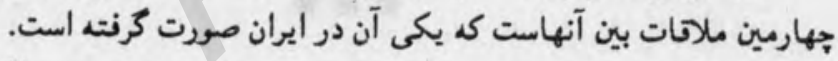

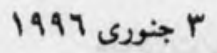

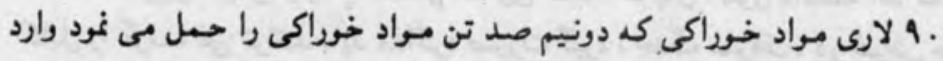

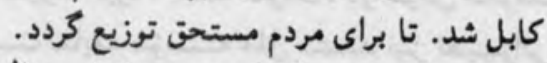

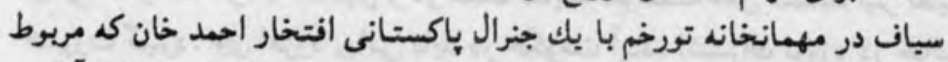

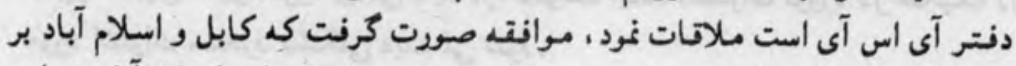

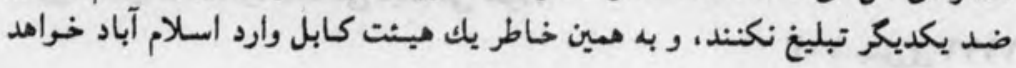
7 جنورى 1997

شد. 
كابل تصميم كرنته نا با طالبان و جنبش مستقيما مذاكره نمايد. يك ميثت سـ نفره كابل وارد مزار شد.

جنورى V

क क

جنرال مالك از حزب جنبش و ناطقى از حزب وحدت وارد اسلام آباد شدند، آنها

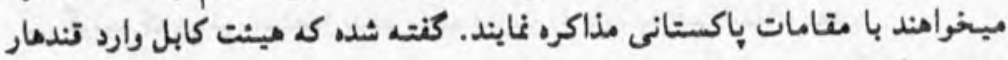
نيز شده است.

A جنورى 1997

$\& \& \&$

احعدشاه مسعود طى مصاحبه اي كفت با تمام جوانب در تماس است. وى طرح

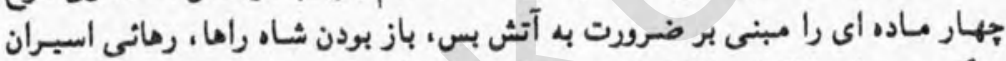

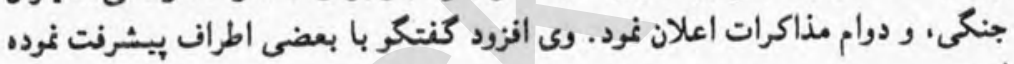

ولايتى ززير خارجه ايران در اسلام آباد با كيلاتى و محمدى ملاقات نموده و در

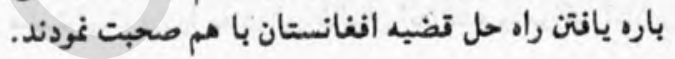
1997 1990وى 19

$\& \& 8$

مذاكرات بين طالبان و شوراى مآهنكى در اسلام آباد جريان دارد، آنان خواهان

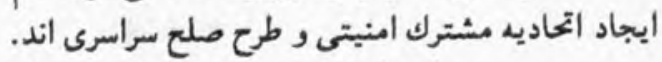

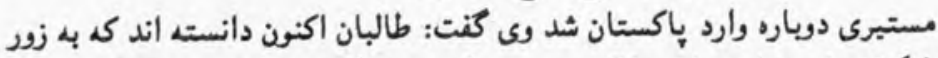

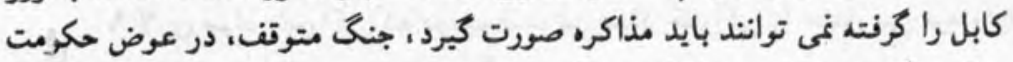

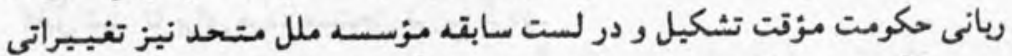

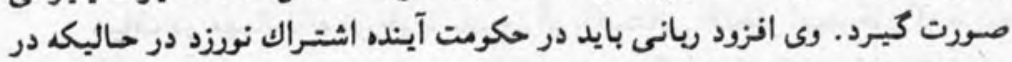
مورد اشتراك مسعود مشكلى ديده نمى شود.

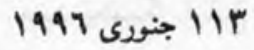

$\notin \notin$

يك هيــت ده نفرى باكســــان از راه كويتهـ روانه هرات شـدند، آنان از طريق 


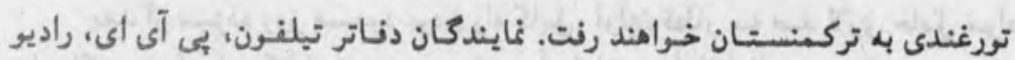

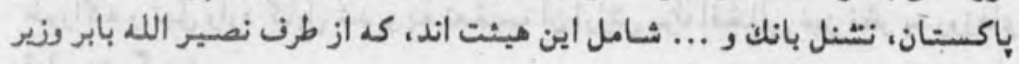
داخله باكستان بدانجا رفته اند.

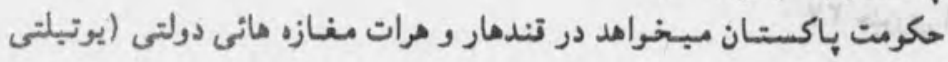
1997 اجنوري ستور) را افتتاح نايد.

\section{$\notin \%$}

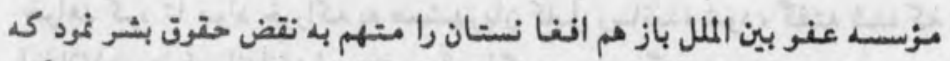

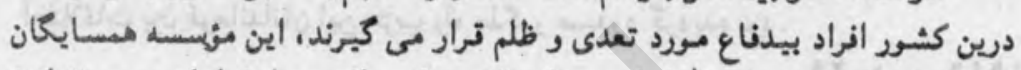

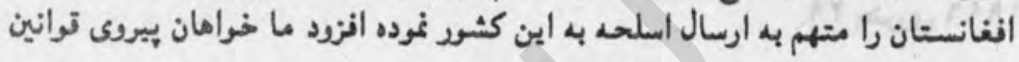
IV 1997 | بين المللى از طرن كروهاى مختلف افنغان هستيم.

\section{$\$ 28$}

مالمعود مستبرى وارد كابل شد، او باز هم اظهار داشت كه طرح جديدى ندارده.

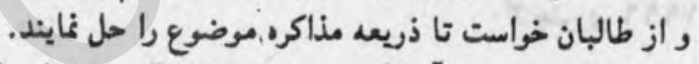

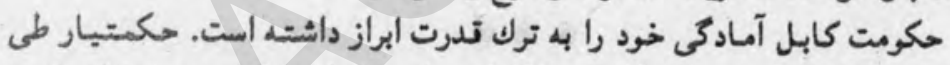

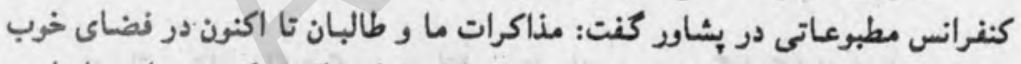

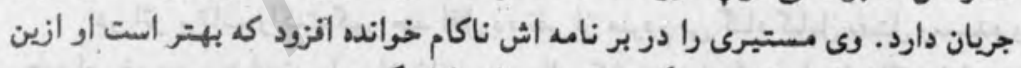
عهده استعفا واده وكسى ديكرى مامور بـ اين كار خردد.

14 إجنورى 1994

$\$ \&$

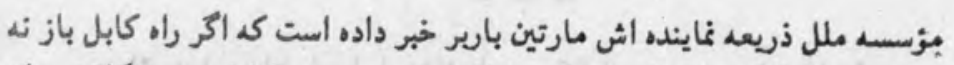

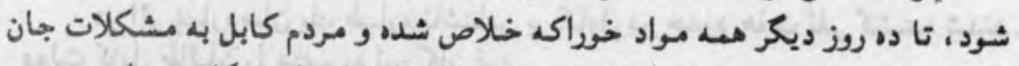

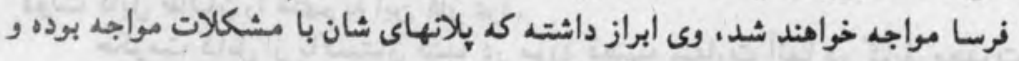

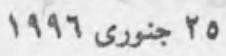

$$
\text { كار ماى شان درست صورت نمى فيرده }
$$


1A. حوادث تاريخى افغانستان/

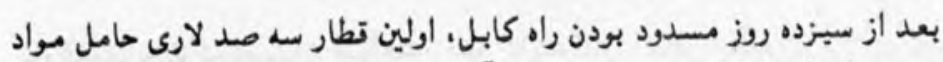

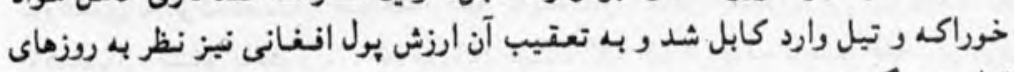
تبل بهتر كرديد. 1997 جنور PV

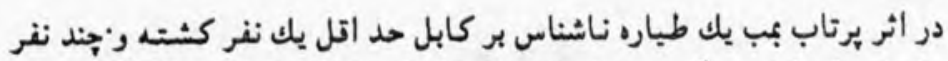

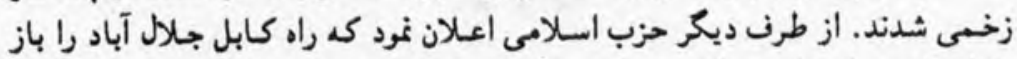

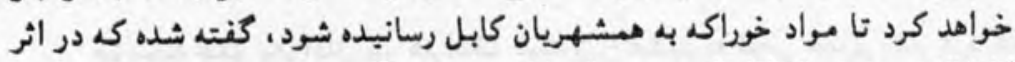

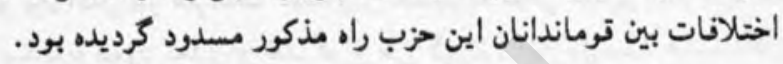
1994 194

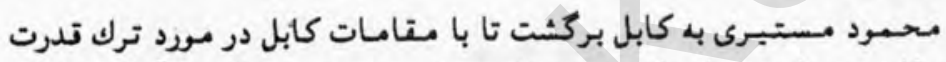

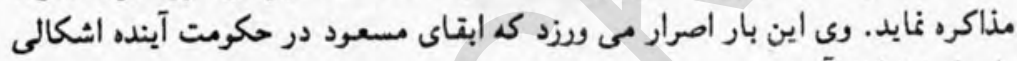
را ببار نخواهد آورد. 1997 197.

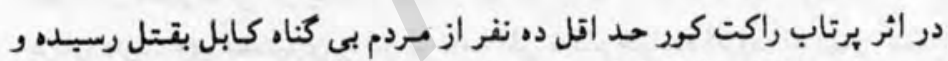

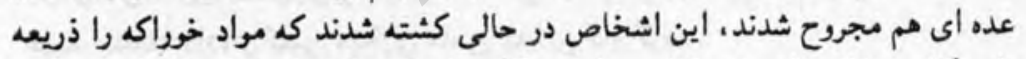

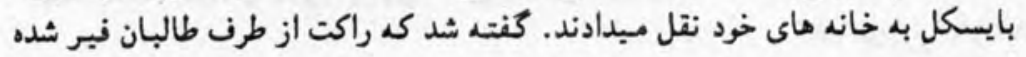

است. آ اجنورى 1947

در اثر بجباردمـان يك طياره ناشناس بر كابل در حابل حدود هنت نفر كشتــ شدند.

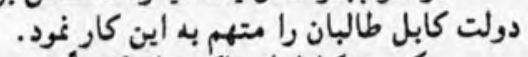

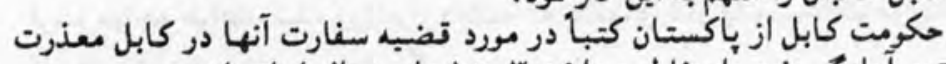

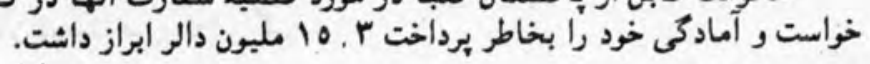

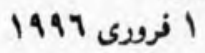


مسنولان كبيسارى عالى ملل متحتد خبر داده اند كي اخر وضع كابل به همين

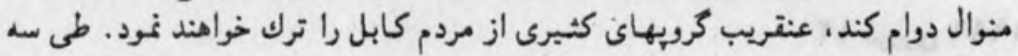

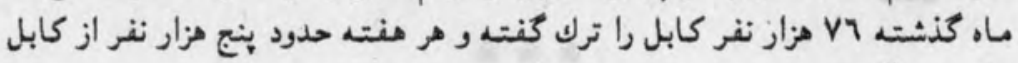

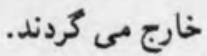

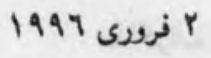

\&\&\&

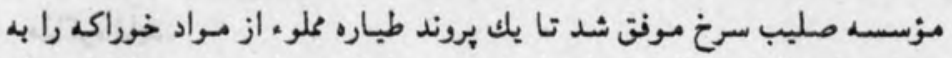

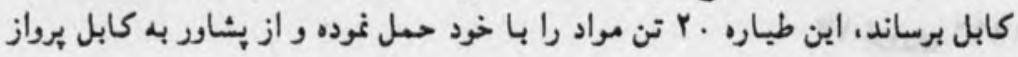

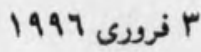
نمود.

$\infty \approx$

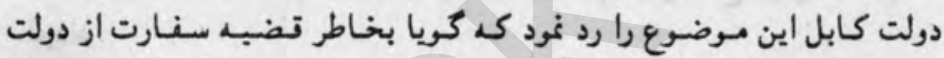

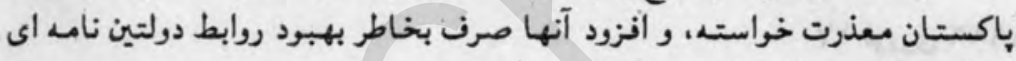
عنوانى حكومت باكستان فرستاده اند.

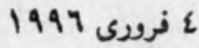

$\$ \$$

يكبار ديكر اسلام آباد ميزيان مذاكرات رهبران افغان كرديد. مجددى، دوستم، محقق و داكتر طالب تا اكنون به اسلام آباد رسبده اند.

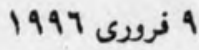

\&\& $\&$

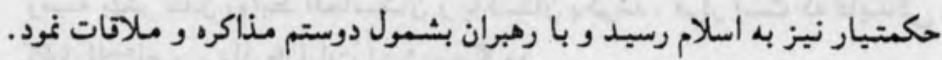

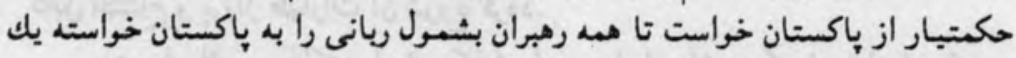

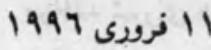
راه حل معقول را بخاطر تضيه انغانستان در بيش كيرند.

$\mathscr{8}$

دولت كابل در مورد مـذاكرات اسلام آباد احتـجاج نمود كفت: اين مـذاكرات 
نتيبه نداده و بايد همجو مذاكرات در داخل انغانستان صورت كيرد.

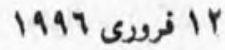

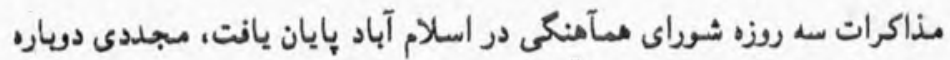

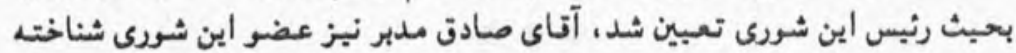

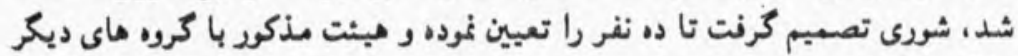
مذاكره نمايد.

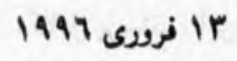

$\$ \approx$

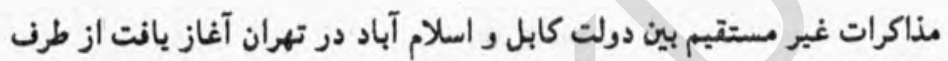

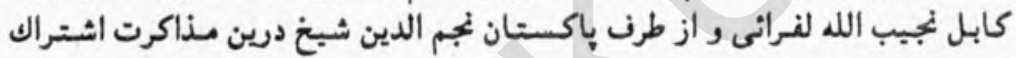
نمودند.

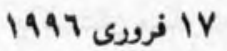

$\$ 88$

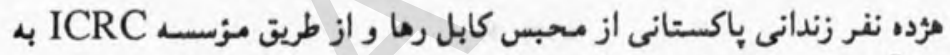

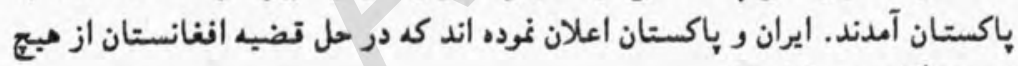
1994 19 194 نوع همكارى دريغ نورزند. $\$ 8$

نماينده رئيم كابل از دولت جين خواسته تا با استفاده از روابط با باكستعان در

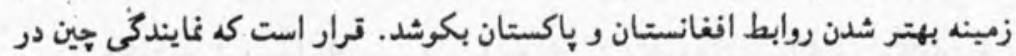
كابل افتتاح و برواز طيارات آن شروع كردد.

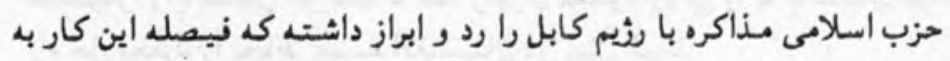

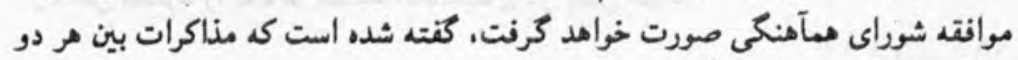
تنظيم خيلى بيش رفته است.

1997 199 
تبل ازظهر امروز جند راكت بر كابل نبر شد ، سه نفر بتتل رسبدند.

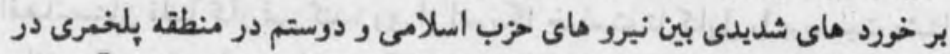

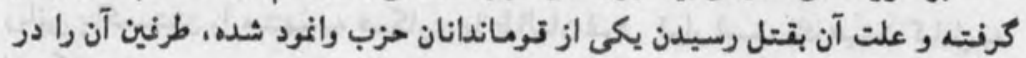
1997 بارت كيرى محلى خوانده اند.

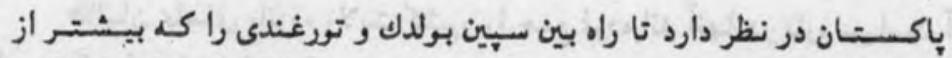

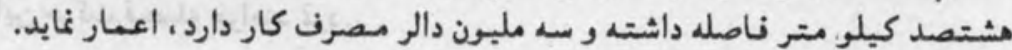

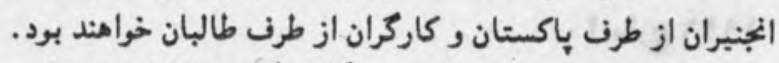

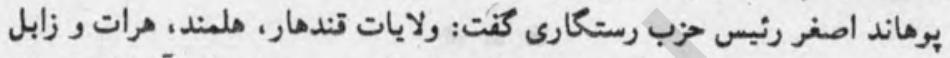

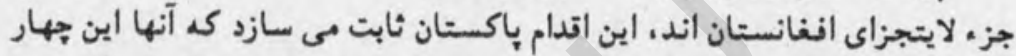

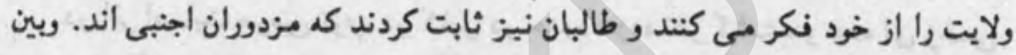
1997 مار

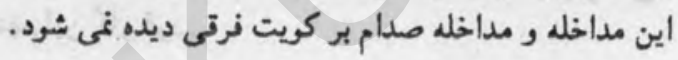

$\$ \$$

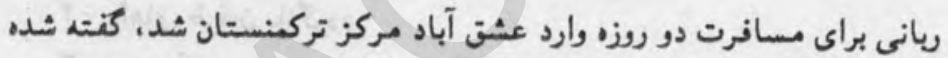
1997 79

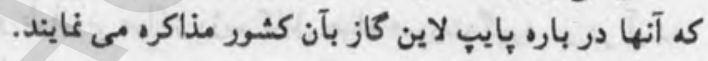
$\approx \approx$

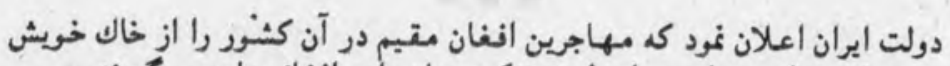

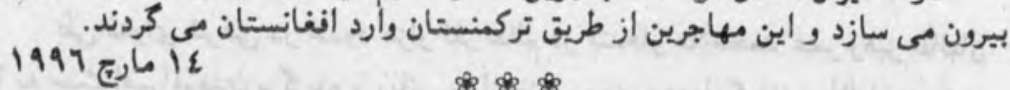

\& \&

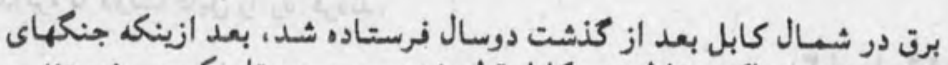

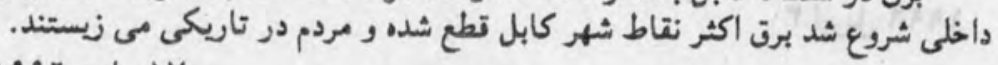

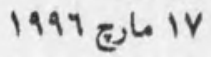




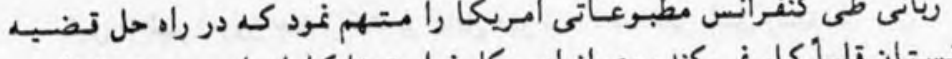

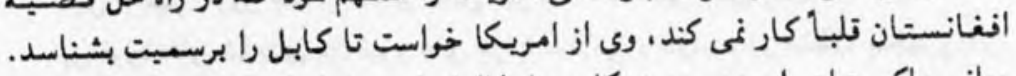

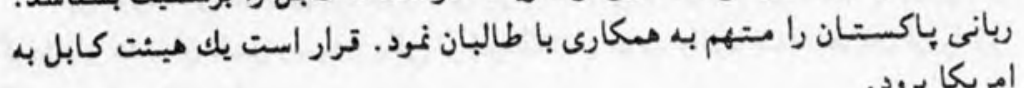
امريكا برود.

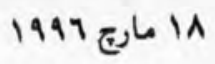

$\$ \&$

طالبان علماى بانزده ولايت كثور را جهع نموده اند آنها در باره سياست آينده اين حركت فيصله خواهند نمود.

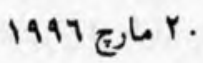

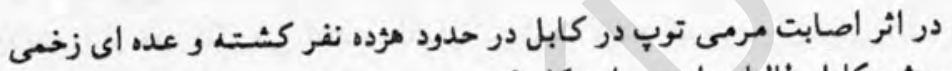

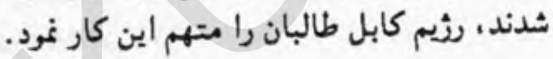

1997 r

جزب وحدت و كروه طالبان در ميدان شهر موافقتنامه ذيل را امضا نمودند:

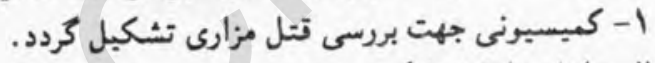

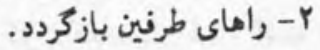

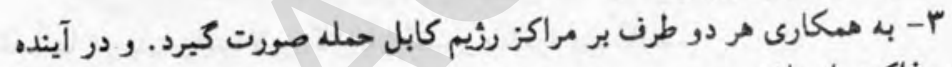

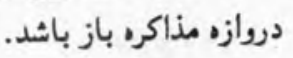

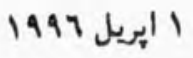

$\$ \& 8$

طى نتواى شرعى در حدود هزار نفر عالم در تندهار ملامحمد عمر رهبر طالبان

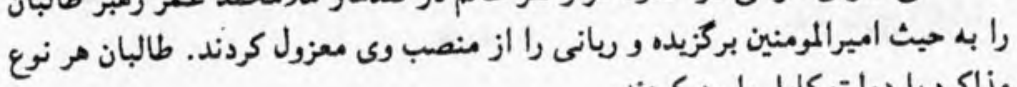
مذاكره با دولت كابل را رد رد كردند.

1999 (ب9 إيريل

$\$ \$$.

حكومت كابل بيشنهاد طالبان مبنى بر ترك حكومت را رد كرده و آنان را كروب.

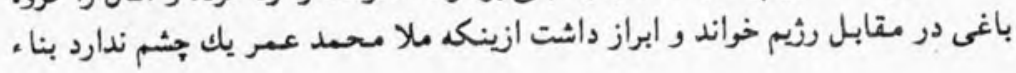


ع إيريل 1997

$$
\text { امير شرعى شده نى تواند. }
$$

$\& \& \&$

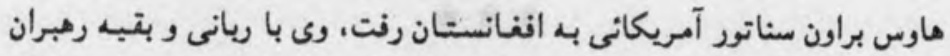

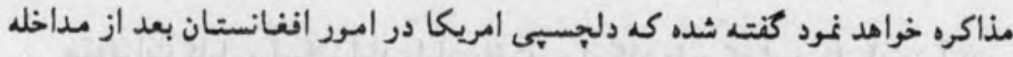

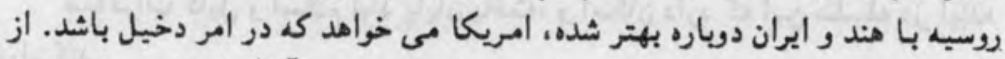

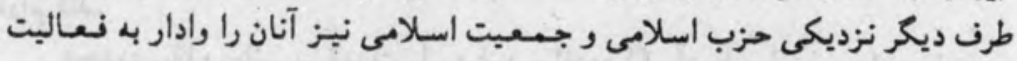
1 إبريل 1997 ساخته است.

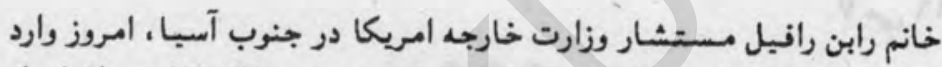

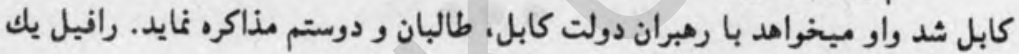
1997 إيريل 19

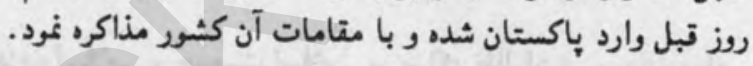

$\$ \& \&$

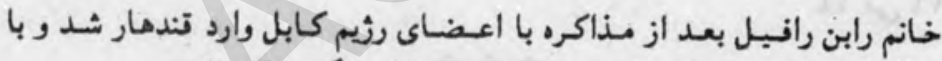

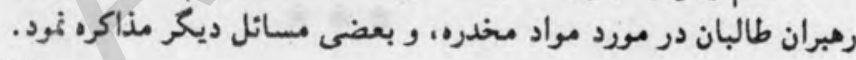

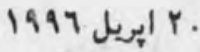

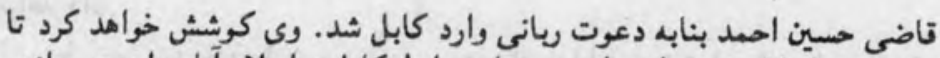

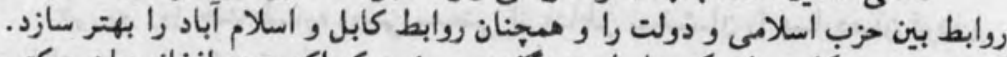

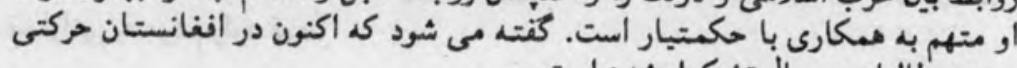

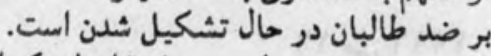

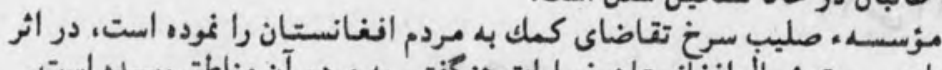

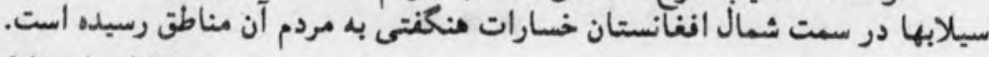
1997 Tr 


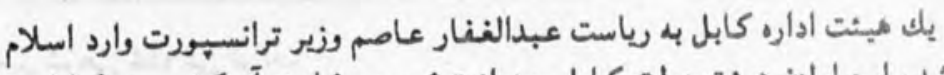

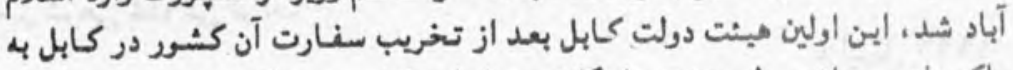
1997 مي

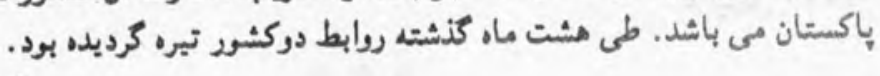

مذاكرات كابل و اسلام آباد بِايان يافت، و امكان دارد كه اين سلسله در آينده. دوار كند.

مجددى بقاء ـ ربانى بر تدرت را رد نمود و افزود اكر آن را بـذيذيريم به اين مفهوم

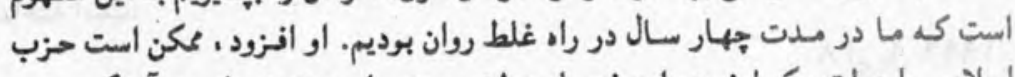

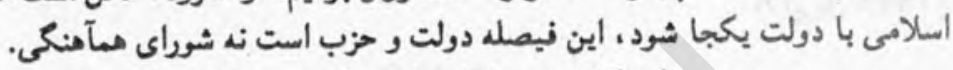

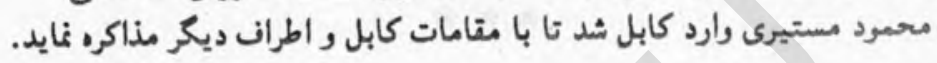
1997 r 197

توتهاى مشترك حزب اسلامى و جمعيت اسلامى بر مراكز طالبان در وردك حملد

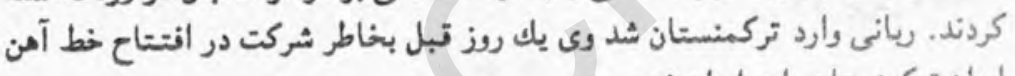

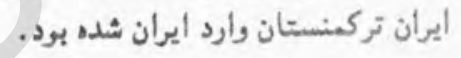
1994 مى 18

$\$ \& 8$

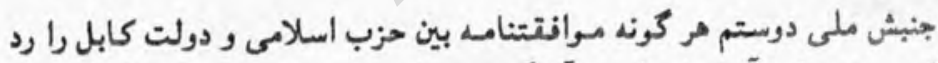

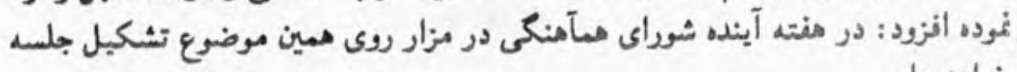
خواهد داد.

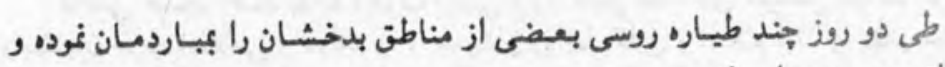
خساراتى به مردم وارد نمود.

1997 مي 19

\&

نجم الدين شينخ سكرتر وزارت خارجه باكستان با ايكورى يوانوف سكرتر وزارت خارجه روسبه در ماسكو روى موضوع الفغانستان مذاكره نمودند. 
يك كنفرانس كد بخاطر موضوع انغانستان در ماسكو تشكيل شده بود بائايان

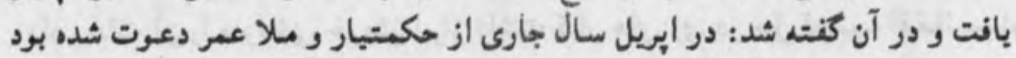

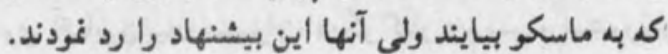

1999 on

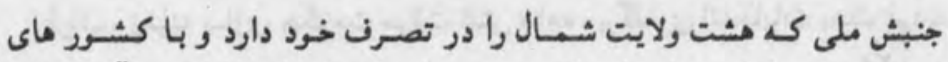

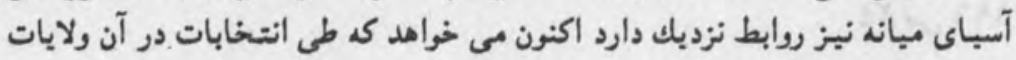

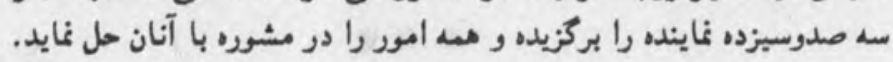
1994 ا 199

ديروز در منطق، ماهيبر ملاتاتى بين ريانى و حكمتبار صسورت كرفتت، درين

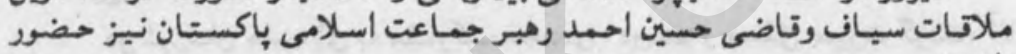

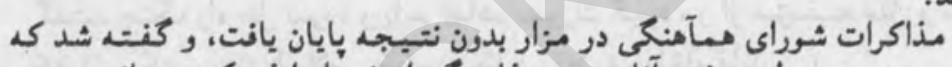

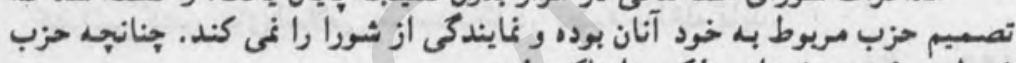
1994 (1) شموليت خود در شوراي مذكور را تاكيد نمود.

$\& \&$

يك مييت طالبان به شمول ملا غنور و ملا بدخشى به آلمان رفتند، طالبان علت آن را دعوت انغانان مقيم آن ديار وانمود نمودند. 1994 r rY

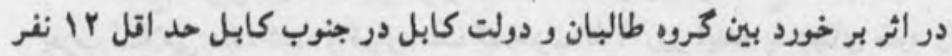

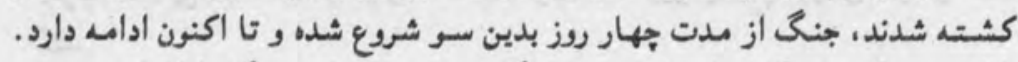

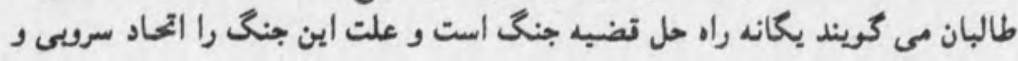

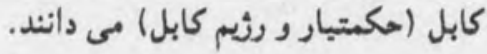

1994 H Tr 
محسود مستيرى ناينده مؤسسه ملل در امور انغانستان از وظبفه اش استعفا

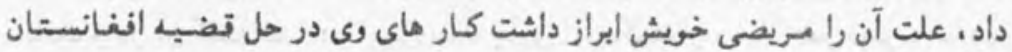

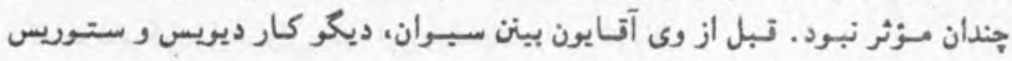
مسوريس عهلده دار اين وظيفه بودند.

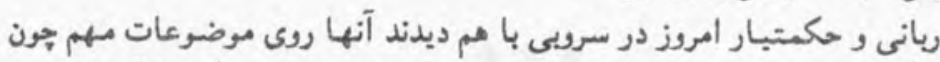

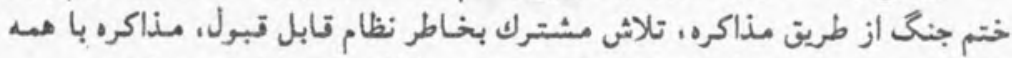

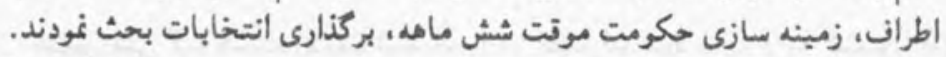

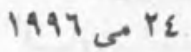

عزيز مراد سخنكوى رياست جمهروى كفت: حكومت جديد بزودى كار را شروع آنا

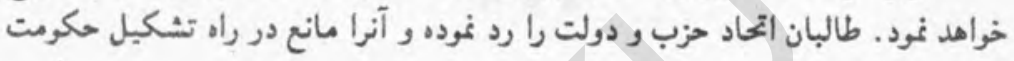
اسلامى دانستند.

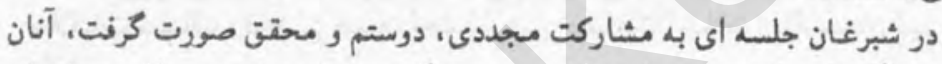

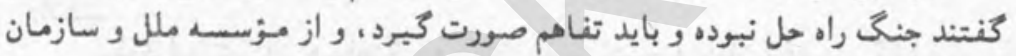

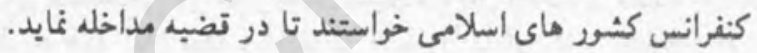

1997 مي

\section{\&8 8}

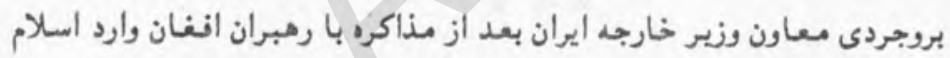
آباد شد. وى مى خواهد با مقامات اخير الذكر روى مسائل انغانستان صسحبت نمايد.

1997 مي

क\& 8

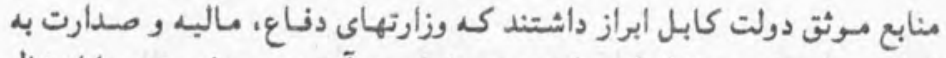

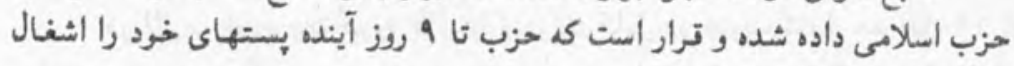


جنرال يوسف نماينده دوستم كفت، حاضر است با ربانى بحيث رئبس جمبعبيت

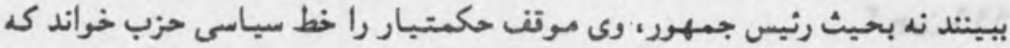

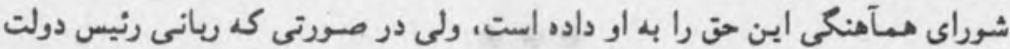

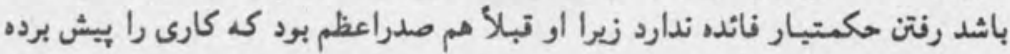

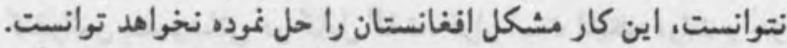

1997 r ra

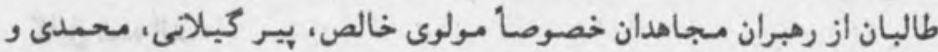

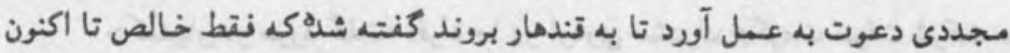

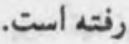

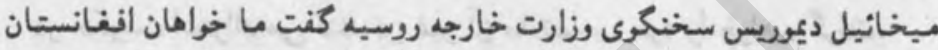

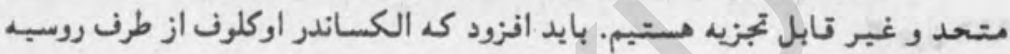
1997 (194. نماينده آن كثور در موضوع حل تضبه انغانستان تعيين شده است.

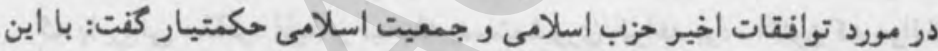

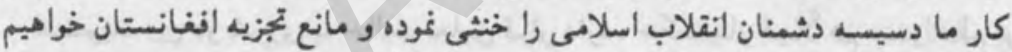

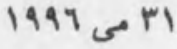
كشت. وى انزود بعد ازين طالبان بيش روى نخواهند توانست.

طالبان ادعا نودند كه مركز ولايت غور را بدست آوردند. آنها ادعاى رثيم كابل

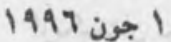

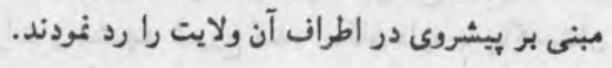

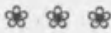

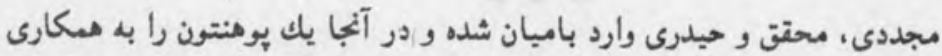

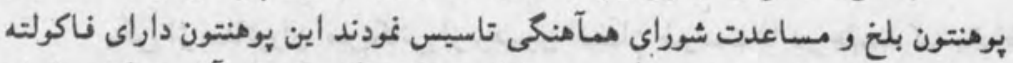

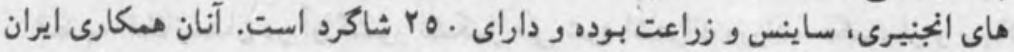


در تاسيس اين بوهنتون را رد نمودند.

1997 Pون

$8 \%$

ربانى طى كنفرانس مطبوعاتى در كابل كفت: ترار است نماينده دولت و حزب

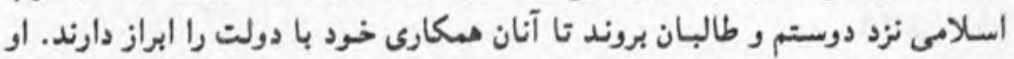

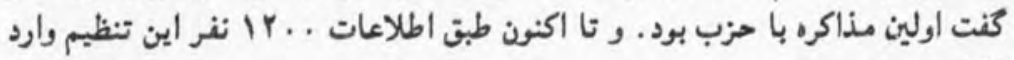

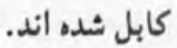

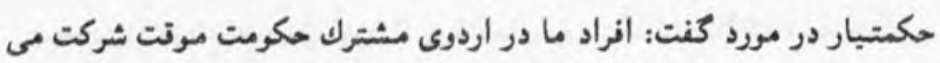

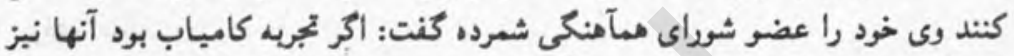

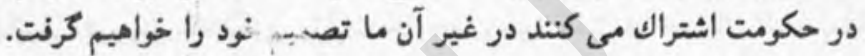

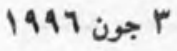

در جلسه تندهار محعدى، كيلاتىى، خالص و مناينده مجلدى اشتبراك ورزيدند.

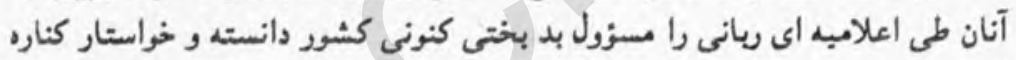

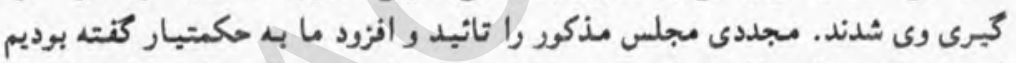

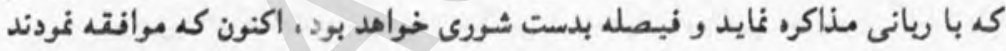

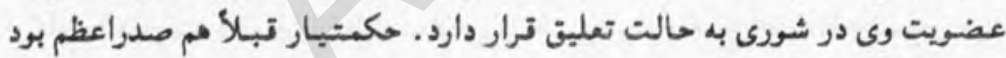

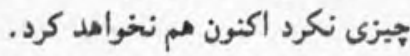

1997 (9

\& \&

ترار است كه يك شركت جديد موا بيـمانى بنام هوإيبـانى بلخ از طرن دوستم

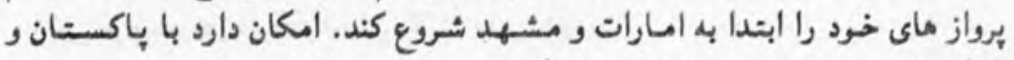

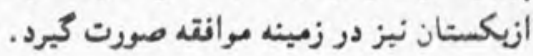

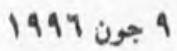

$\Leftrightarrow \&$

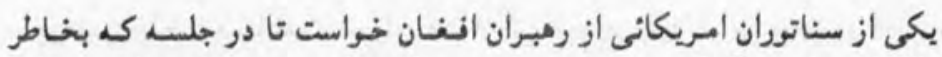

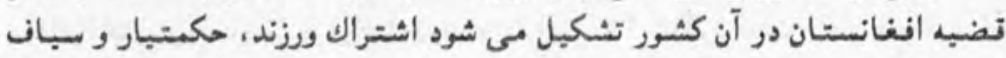


1997 14

شامل اين رهبران نبستند زيرا امريكا آنانرا بنيادكرا خوانده است. $\notin \&$

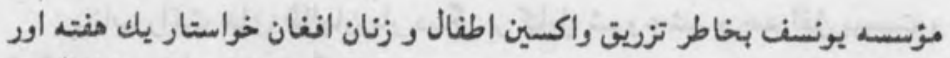

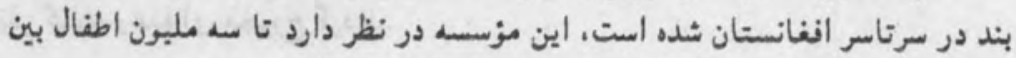

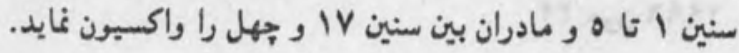

10

$\notin \otimes$

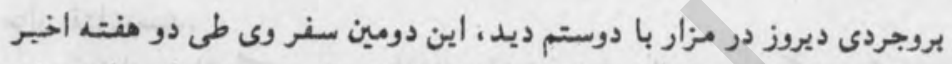

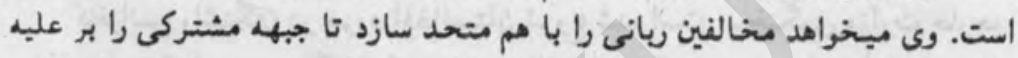

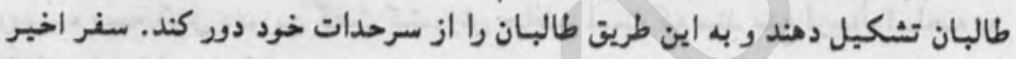

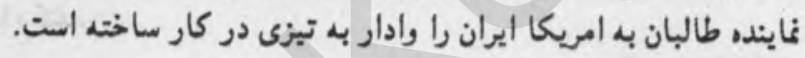

1997 19

\&8 8

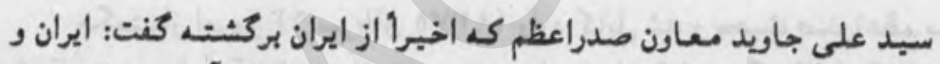

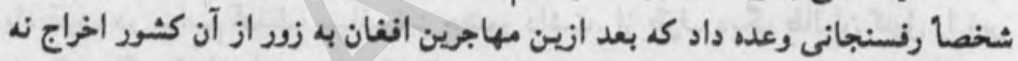

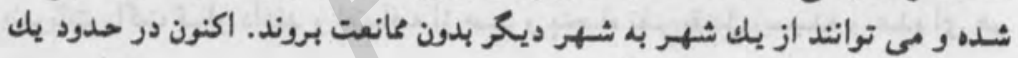

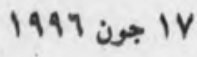
مليون مهاجر افغان در ايران زندكى دارند.

$\notin \approx$

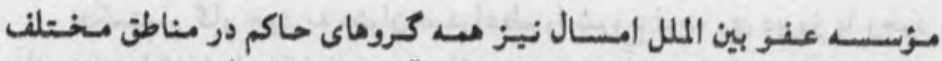

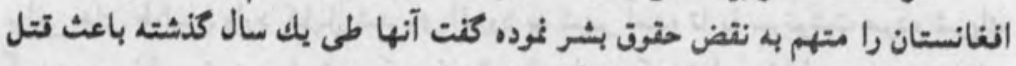
11 1949

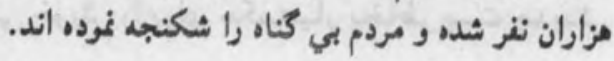

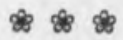
حكومت امريكا نروش هر نوع اسلحه به انغانستـان را منوع ترار داد، و انزود 
اين كار را بخاطر تقاضاى هاى مكرر مؤسسه ملل نموده است.

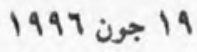

يرتاب راكت هاى طالبان بار ديكر بر كابل شروع شد و حهد اتل بيست و هند نفر كثته وعده اى مجروح گرديد.

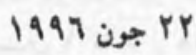

دكر جنرال رسول بهلوان معاون شوراى سعت شمال و مسزول نظامى فارياب در مزار بقتل رسيد. - مبران.

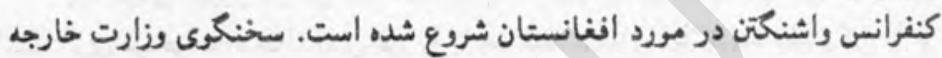

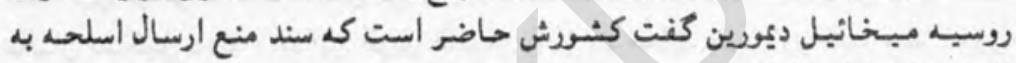

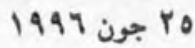

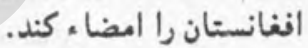

$\circledast \infty$

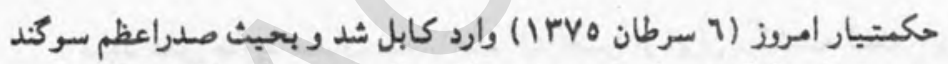

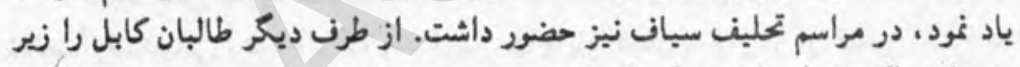

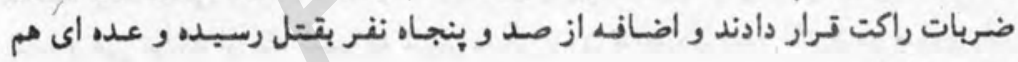

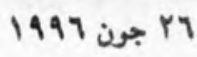

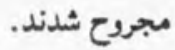

$\$ 8$

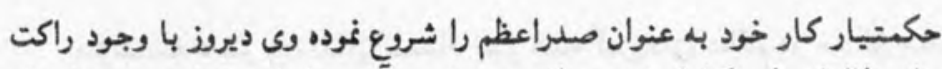

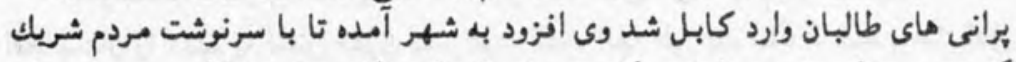

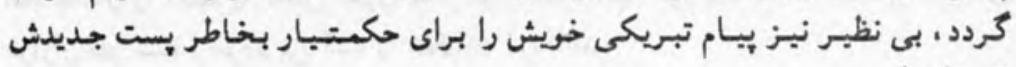

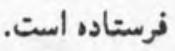

1997 جو Pr 


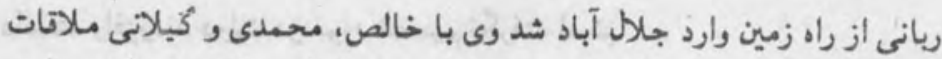

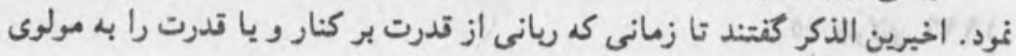

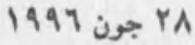

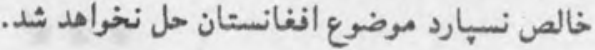

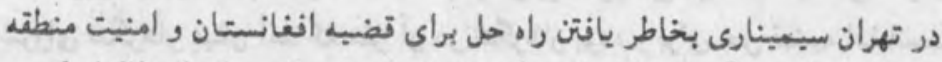

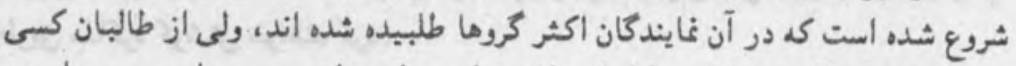

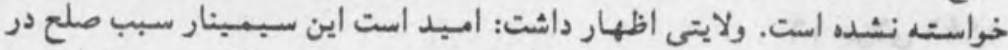

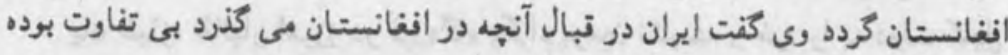

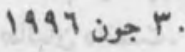
نمى تواند.

خليلى از نزديكى حزب اسلامى و دولت استـبال نموده و آنرا يك كام مشبت

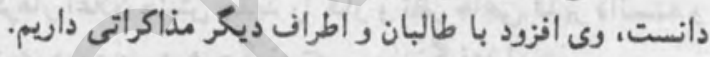

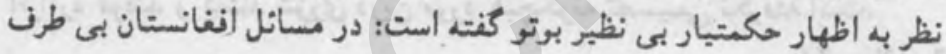

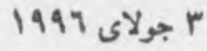
خواهند ماند، ديروز ي يام حكمتيار ذريعه غيرت بهير به وى سبرده شد. $\& \%$

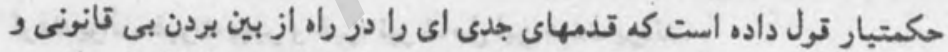

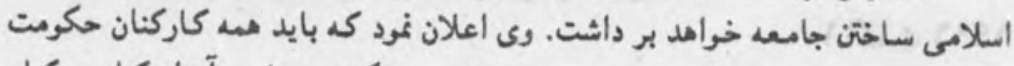

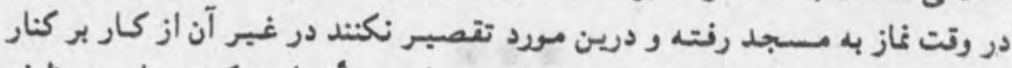

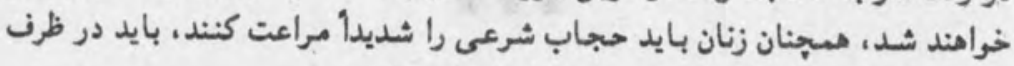

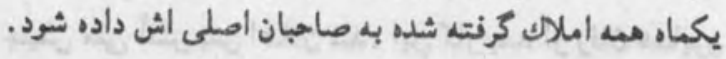

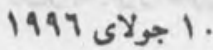

$\% 8$

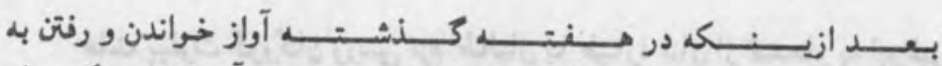

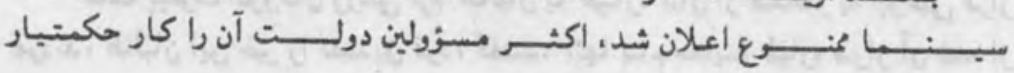


دانسته وافزودند دولت در مورد تصعيم نكرفته است.

10

روز دوشنبه كذشته يك اثتلاف جديدى بين كروهاى دوستم ،مجددى، كبلانى و

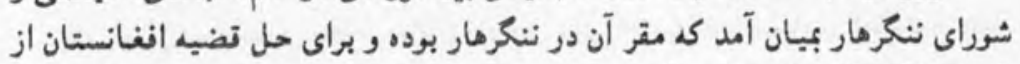
طريق مذاكره كوشش خواهند كرد.

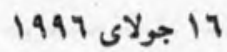

يك طياره طالبان امروز در فرودكاه بحرام بزمين نشسته و خود را به دولت كابل

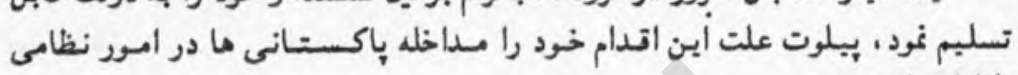
طالبان دانست. 1V

\&8 \& 8

اعضاى شوراى ننكرهار اعلان جنبش جديد را كار و نظر حاجى تدير دانسته و

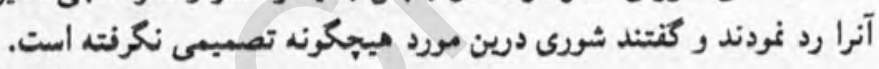

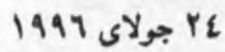

$\because \%$

هينت هشت نفرى دولت كابل بد رياست يونس قانونى وارد اسلام آباد شدند،

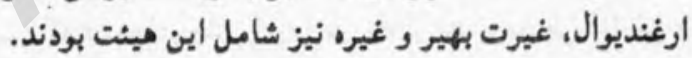
1997 11. 20.

\&\&

بين دولت كابل و جنبش ملى آتش بس اعلان شد، اين كار بعد از رنتن معايون جرير به مزار صورت كرنته است.

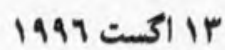

$\nLeftarrow$

هنت بِيلوت كروگان روسى نزد طالبان با طياره شان از تندهار به ابوظبى نرار

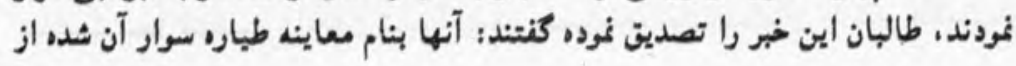


1999 ا 19

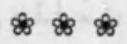

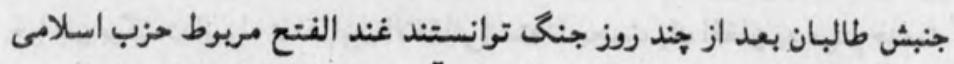

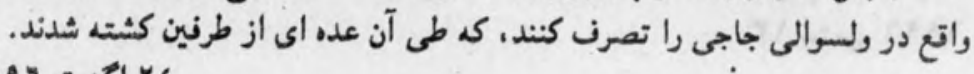
1994 Y

شاهراه كـابل سـالنخ به روى ترانبك باز كرديد، اين جـاده از مـدت مـديدى

1994 ت34

حكمتـبـار بر ضـد كسـانى كه در متـابل حكومت مى رزمند اعلان جهاد نمود

1997 1979 9 منظور او كروه طالبان است.

$\$ 8$

كفته شده كه جنگ بين كروه طالبان و شوراى ننكرهار در منطقه حصارك در

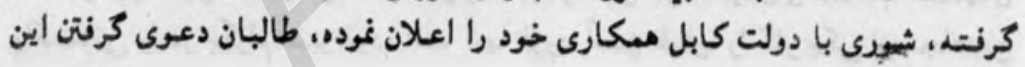
1994 19 ستبمر 1.

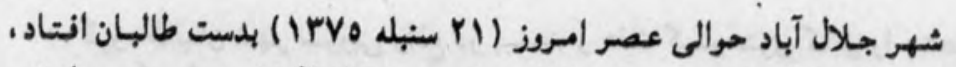

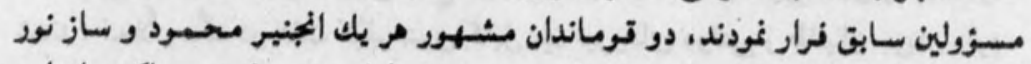

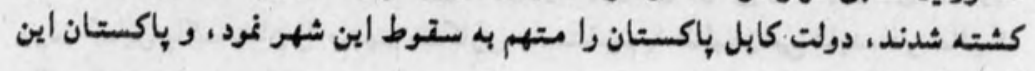
1999 11 


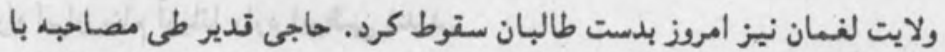

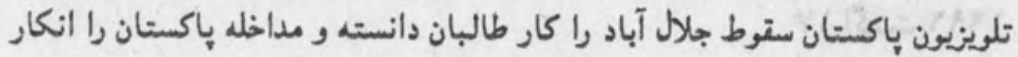

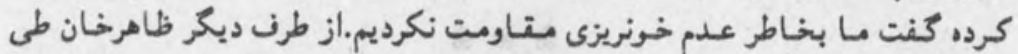

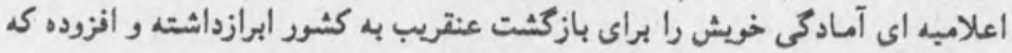

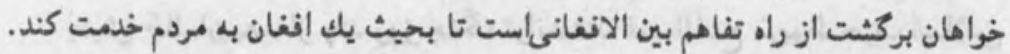

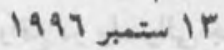

$\nLeftarrow \%$

طالبان امروز ولايت كنر را تصرف نمودند، اكنون آنان در آرزوى تسخبر كابل

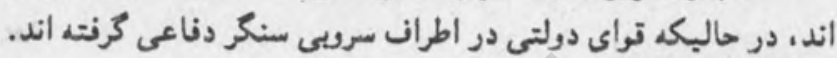
1997 أنمبر

هكومت كابل از مزوسته ملل خواست تا مداخلات مستقبيم باكستان در امور

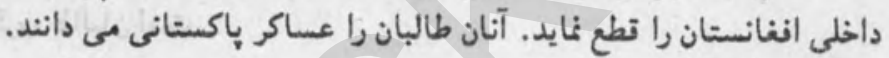

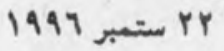

\section{$\$ 8$}

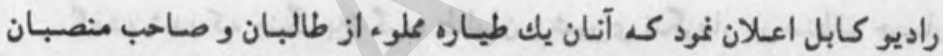

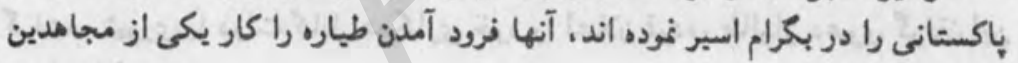
1999 YE دانسته اند.

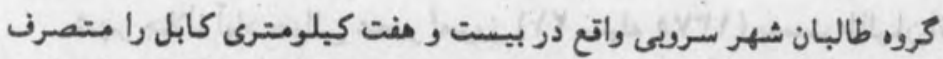

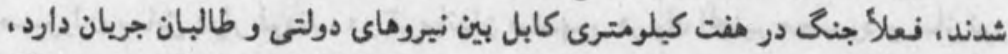

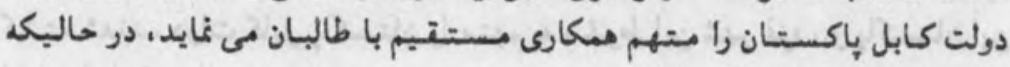
1997 Yo

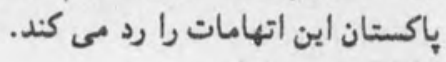




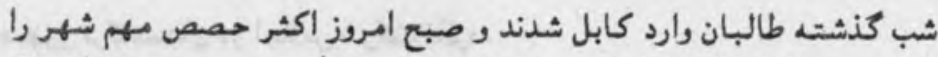

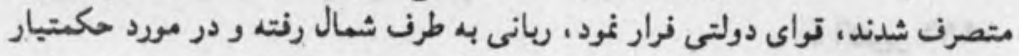

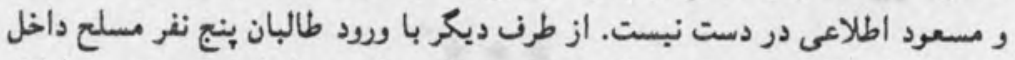

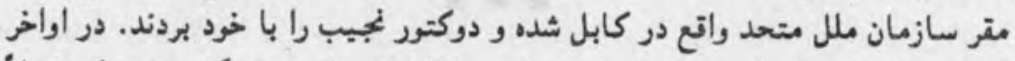

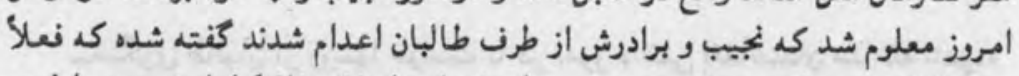

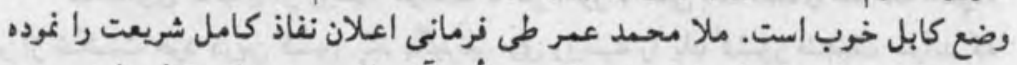

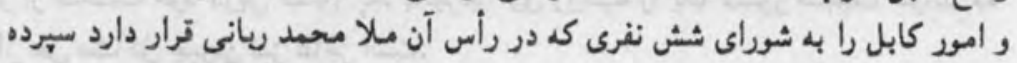

\section{9 rv}

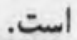

\section{$\$$}

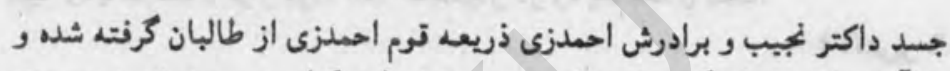

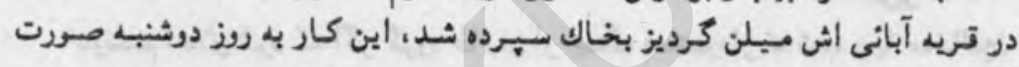
كرنت.

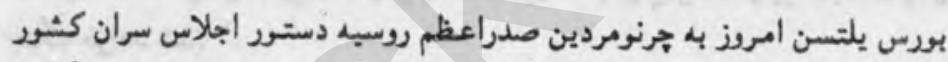

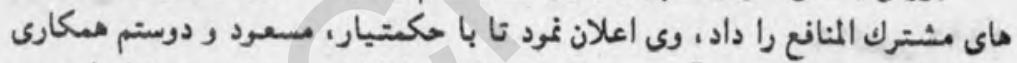

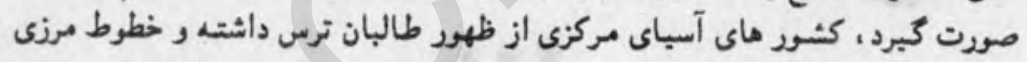
| اكتوبر 1994

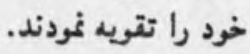

\section{$\% \%$}

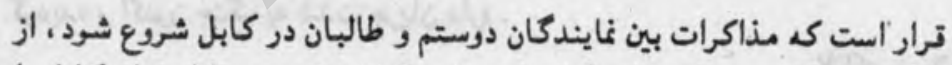

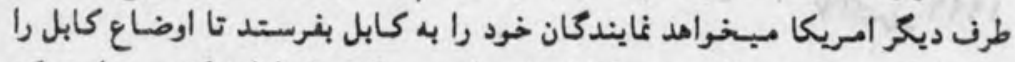

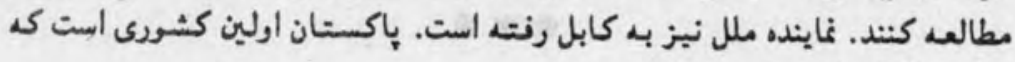
ب اكتوبر 1949 دولت طالبان را برسميت شناخت.

\& \& \&

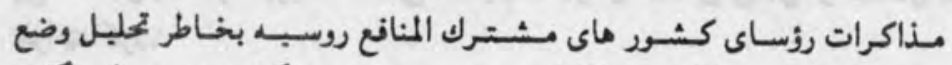

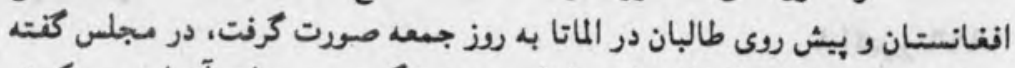

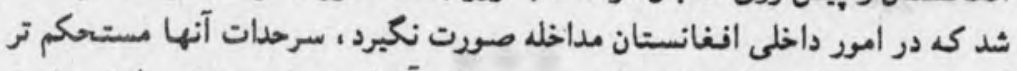

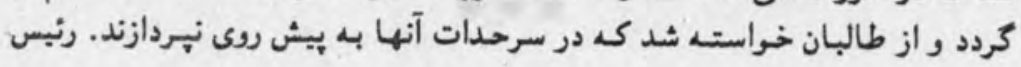


جمهور تركنستان در اجلاس شركت نكرد.

أ اكتوبر 1949

سخنكوى طالبان از روسها خواست تا در امور داخلى انغانستان مـداخله ننهوده

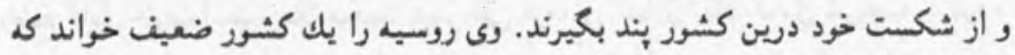
از حل مشاكل جيجهن نيز عاجز است.

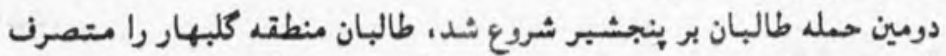

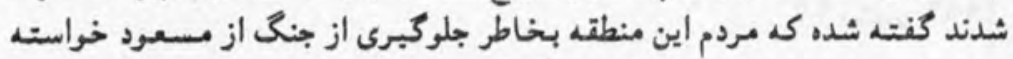

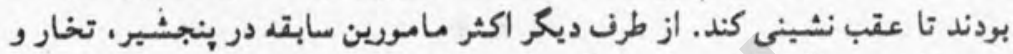

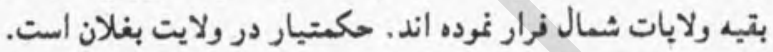

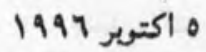

دوستم اعلان نمود كه اكر كروه طالبان از جنح دستبردار نه شده و با مخالفين

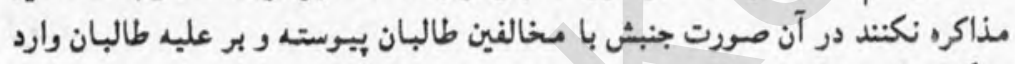
جنش خواهد شد.

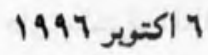

\section{$\& \& \&$}

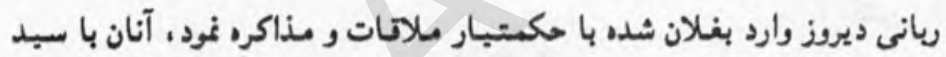

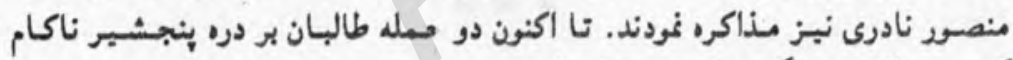

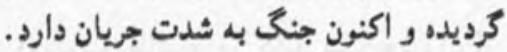

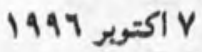

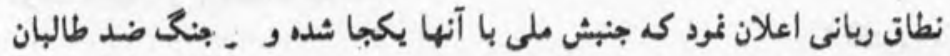

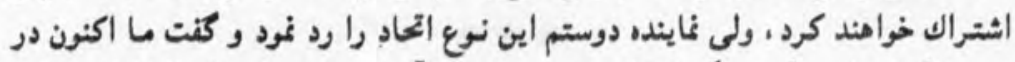

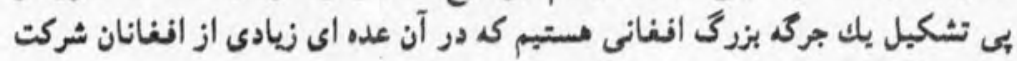
1997 اكتوبر 1997 


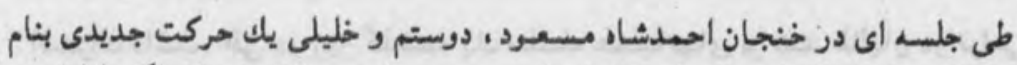

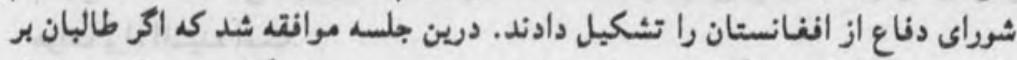

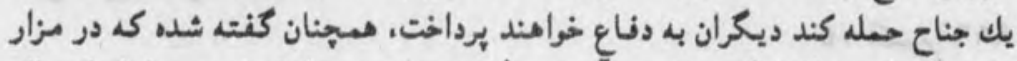

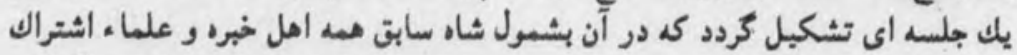

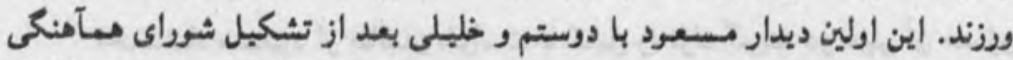

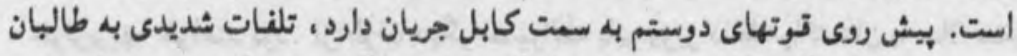

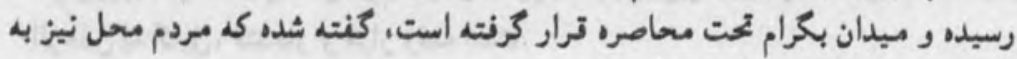

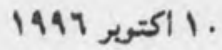
طرندارى مسعود يرداخته اند.

88

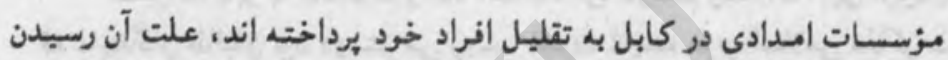

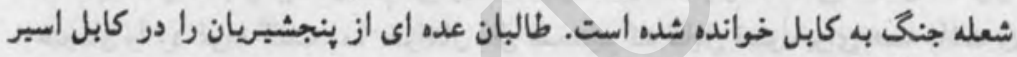
1997 111

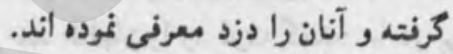

के

شهر جبل السراج بعد از جنگ شديد بدست نبروهاي احمدثاه مسعود افتاد.

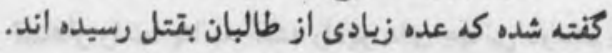

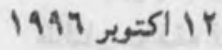

بعد از بِيش روى نيروهاى احمدشاه مسعود اينك شهير جاريكار نيز بلدست آنها

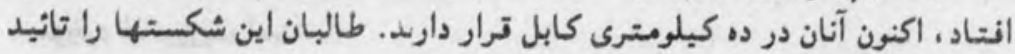
1997 194 اكتوبر

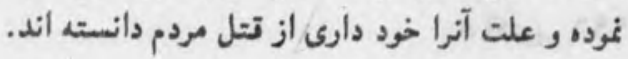

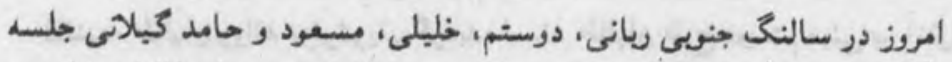

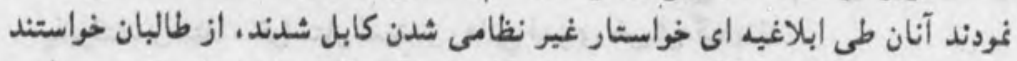

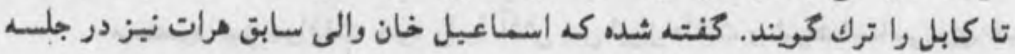


اثتراك داشت، طى دو روز كنشته يك سلسله عملياتهاى بر ضد طالبان در نواحى

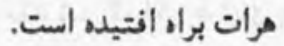

ع 1994 اكتوبر

احمدشاء مسعود از طالبان خواست تا كابل را ترك كويند در غير آن مستول

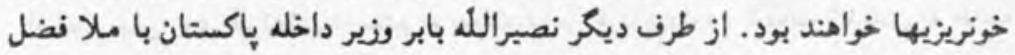
الرحمن به كابل، تندهار ور مزار رفته است.

1947 اكتوبر 19

نصيرالله بابر با ملاغوث ر ملا الله داد نزد دوستم رفته اند ، اين اولين بار است

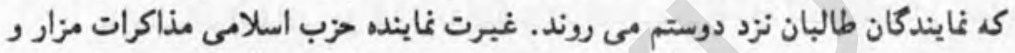

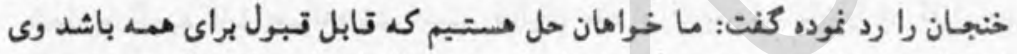

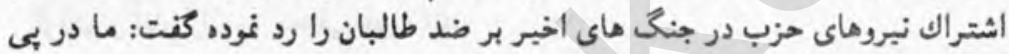
1997 197 (19 اكتوبر

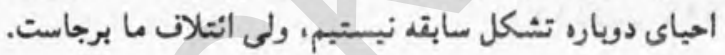

\section{$\$ \& 8$}

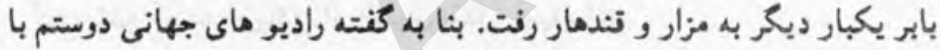

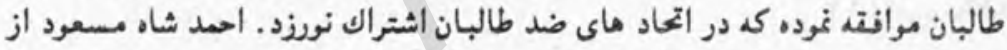

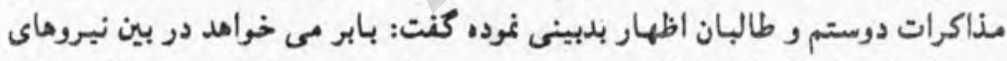

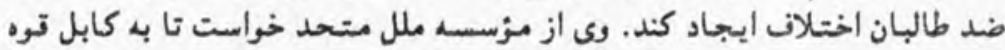

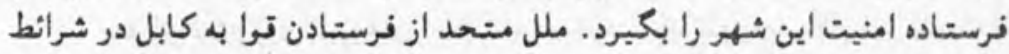

1 1947 موجود ابا ورزيده است.

يك روز تبل ميدان هوانى بحرام دوباره بدست نيروماي مسعود افتاد ، بابر بدون

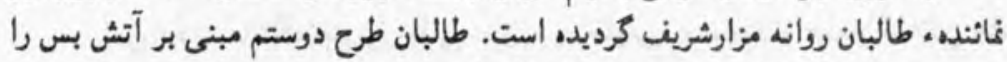

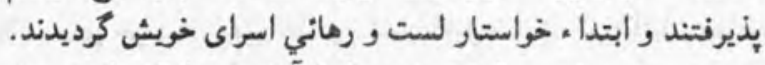

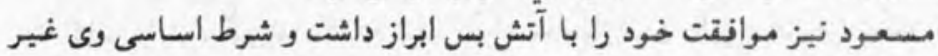


نظامى گردانبدن شهر كابل اعلان شده است. طالبان مى كريند كابل غير نظامى است ر امنيت آن اكنون بدست بوليس استران.

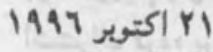

$\$ \&$

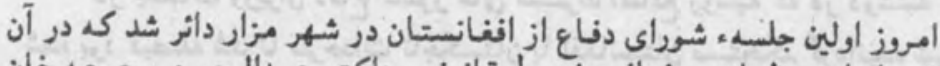

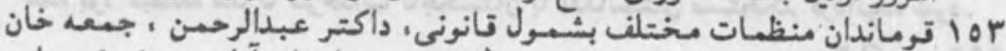

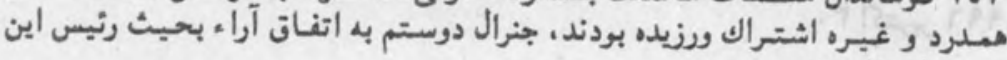

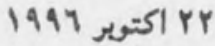

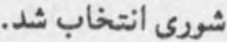

حكومت هاى ايران، روسبيد و هند اعلان نمودند كه حكومت آتاى ربانى را به

1994 ( 199 رسميت مى شناسند، طالبان نزد آنها رسميتى ندارند.

$\$ 8$

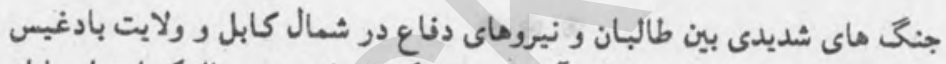

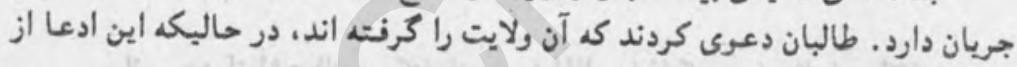

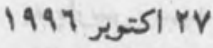
طرف سخنكوى دوستم بة شدت رد شده است. $\$ \&$

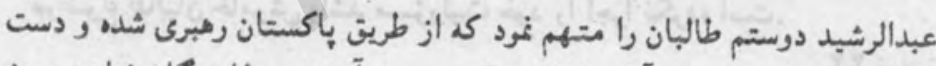

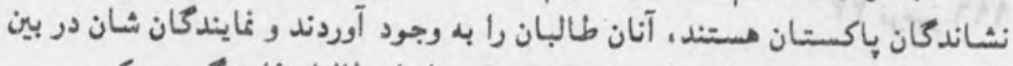

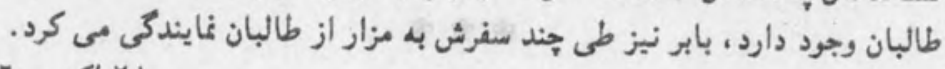

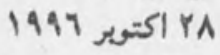

$\$ \%$

ملا متقى سر يرست وزارت اطلاعات طالبان بر ضد دوستم اعلان جهاد نود،

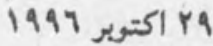

وى جند وقت قبل او را شخص مسلمان خوانده بود. 


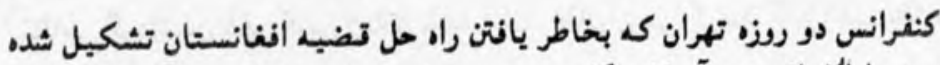

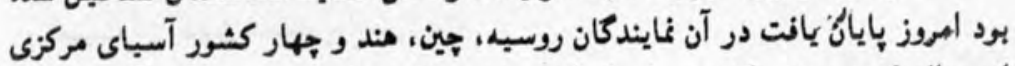

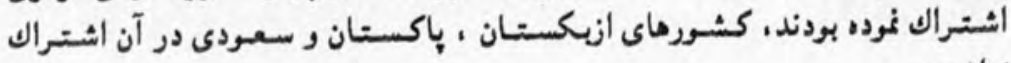
نداشتند.

در جلسات وزيران دفاع كشور هاى مشترك المنافع روسيد كه در دوشنبه تشكيل

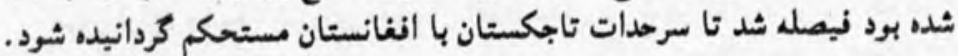

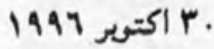

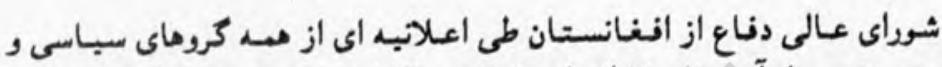

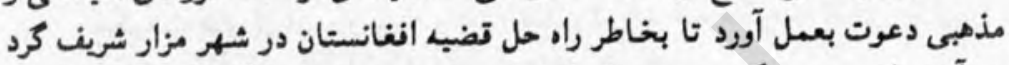

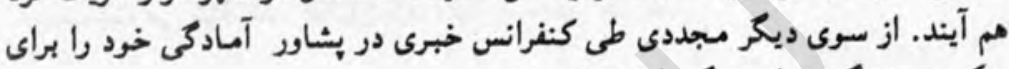

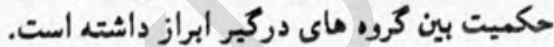

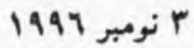

ربانى بعد از اشتراك در كنفرانس بين المللى غذا كد در ايتائيا بر كذارشده بود

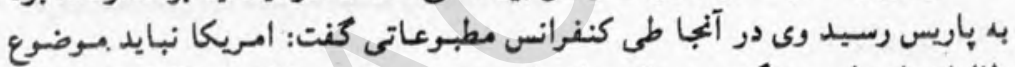

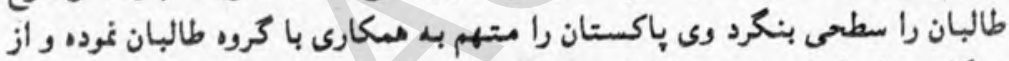

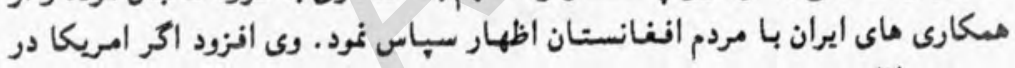

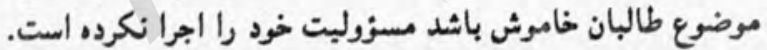
1947 نو YY 


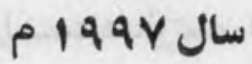

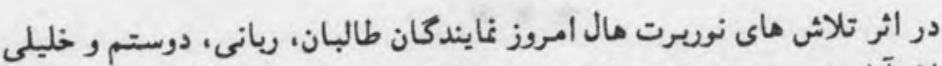

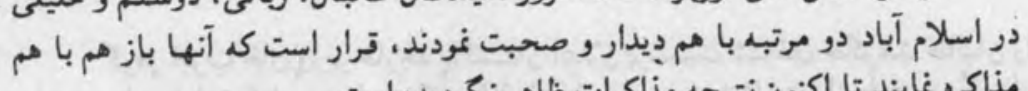

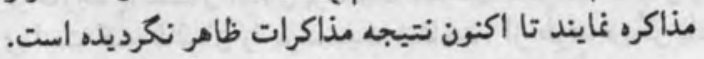

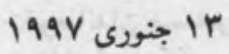

\& \& \&

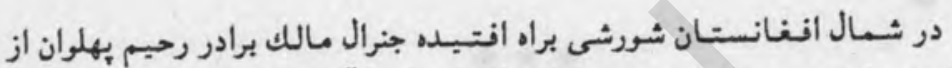

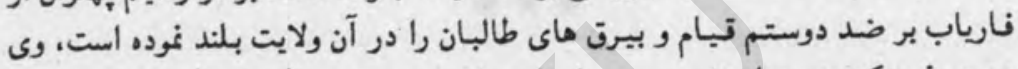

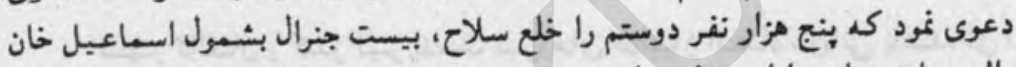

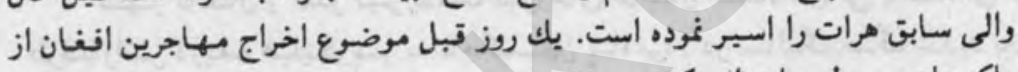

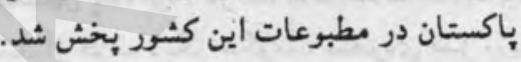

1997 م 19

$\$ \$ 8$

در حالبكه مطبوعات باكستانى از بيشروى سريع السبر طالبان در سمت شمال

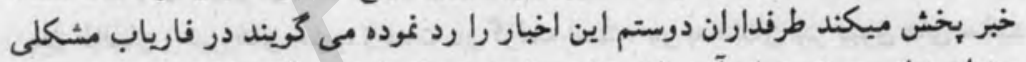

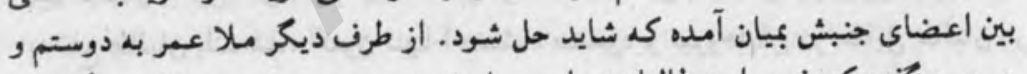

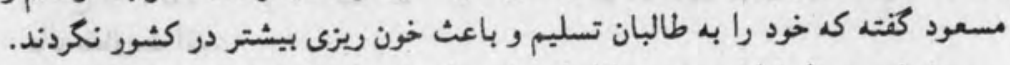

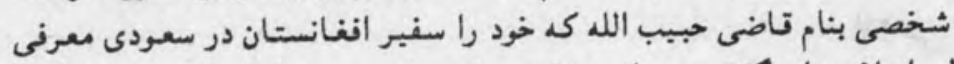

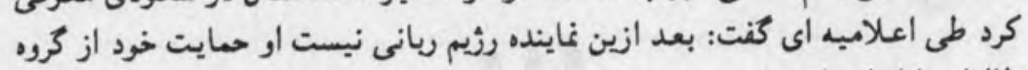

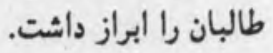
199V مr.

\section{$8 \%$}

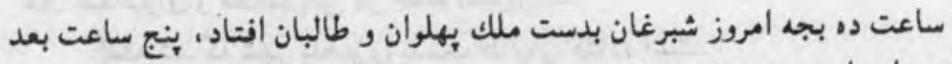

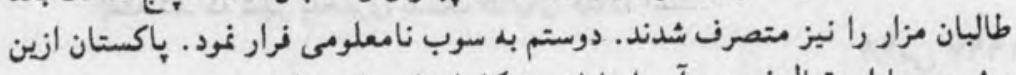

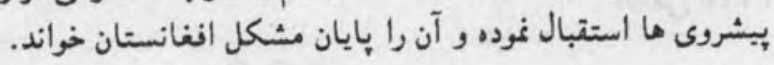




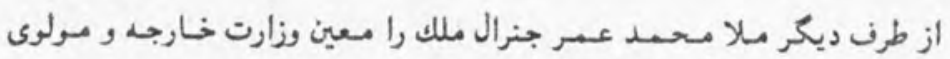

$199 V$ V re

$$
\text { عبدالرزاق اخوند را مسؤول سمت شهال تعبين نمود. }
$$

$\$ 28$

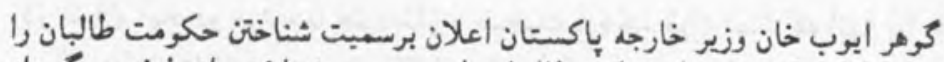

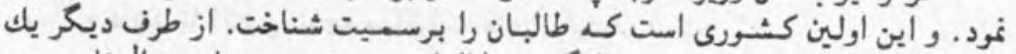

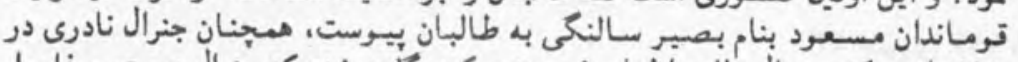

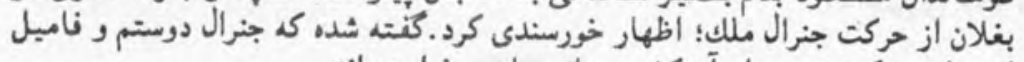
1997 ro

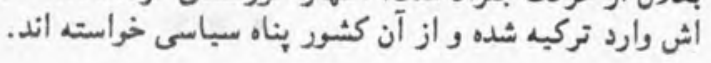

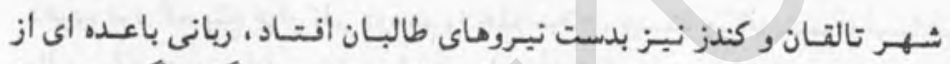

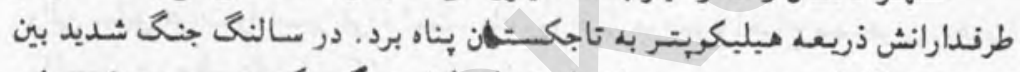

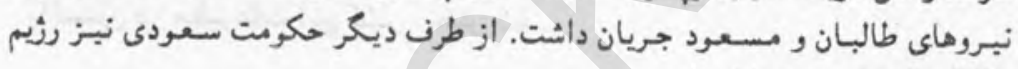
199V ry طالبان را برسمبت شناخته است.

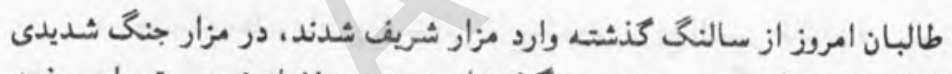

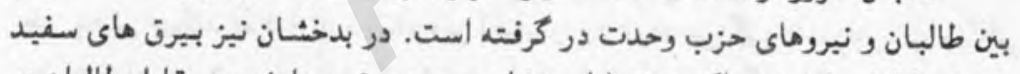

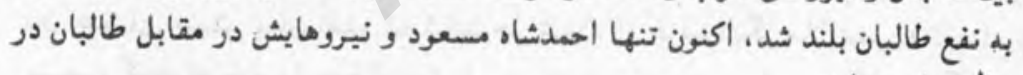
1997 rV rV

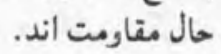

88

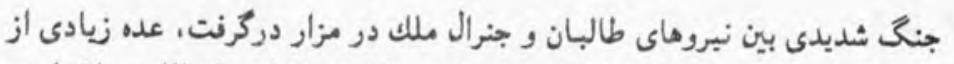

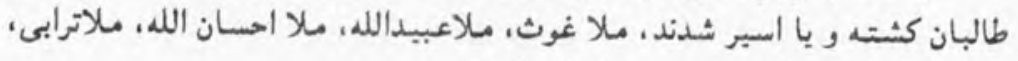

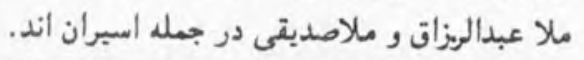
199V G.TA 


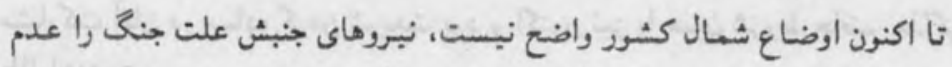

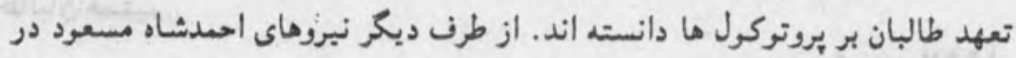

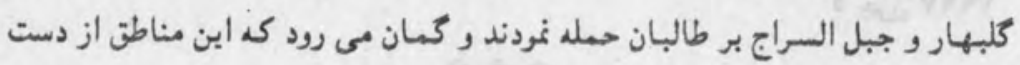

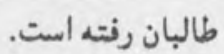

قرار يك خبر ديكر جنرال ملك امروز در مزار از طرف علدا . و موسفبدان بحبث 1994 ra رهبر جنبش تعبين شد.

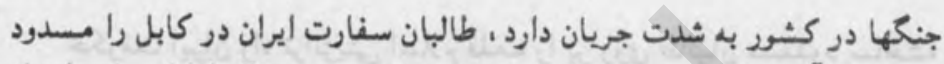

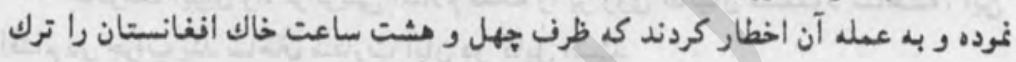

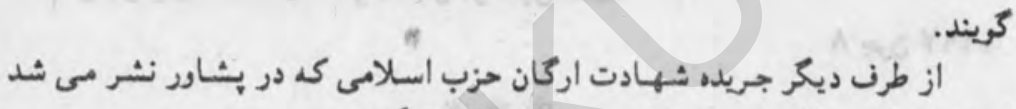

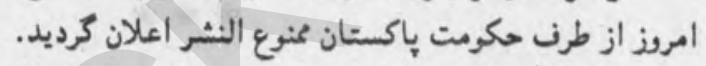

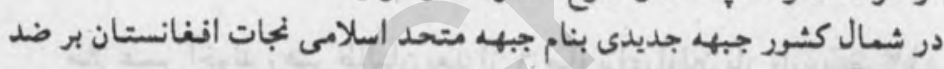

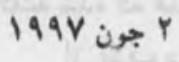

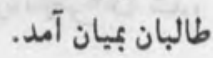

\section{$\$ 8$}

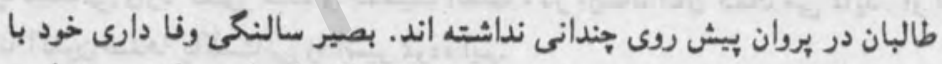

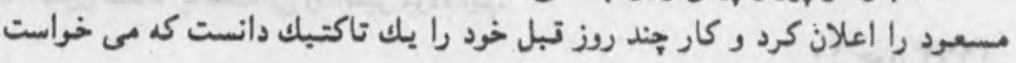

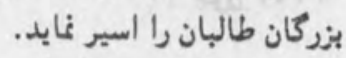
حكومت هند راكتهاى بلاستيك را در سرحدات باكستان نصب كردند.

\section{ع أع ان}

\section{$\% \%$}

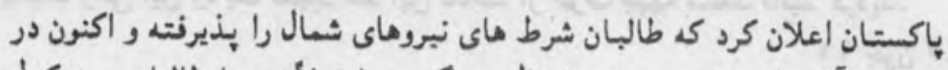

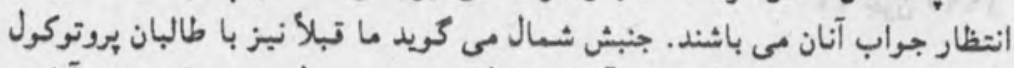

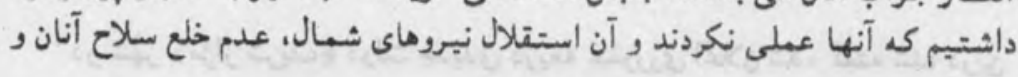




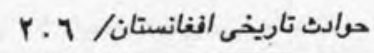

مشاركت آنان در بياده كردن شريعت بود و اكنون نيز با هين شروط حاضر مذاكره با

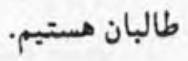
1997 جون

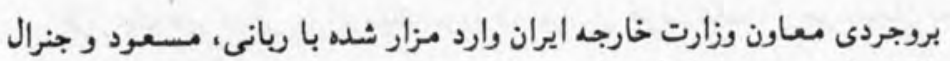

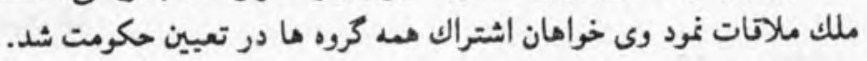
1997 199

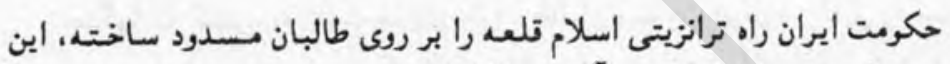

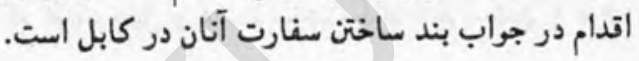
A جون 1994

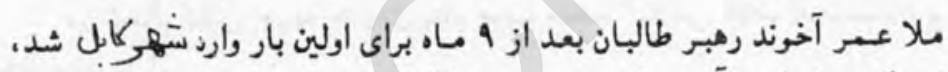

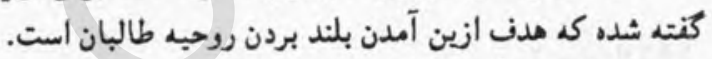

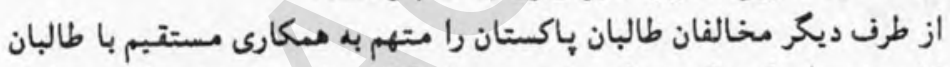

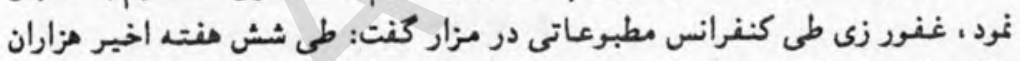

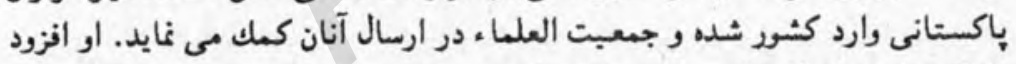

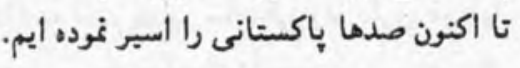
1997 جون 19.

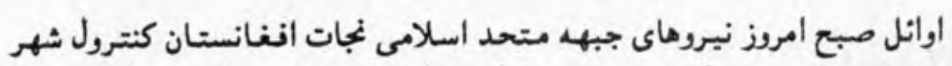

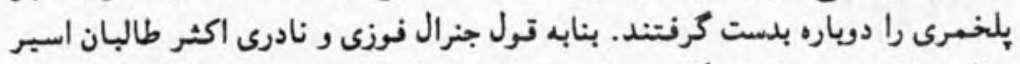

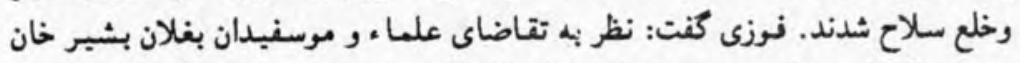

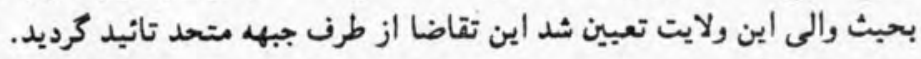
111997

در شهر " مزار شريفه دولت جديدى ذريعه غفورزى اعلان شد، كفته شده درين 


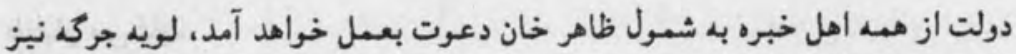

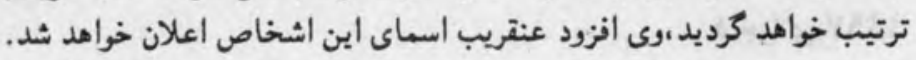

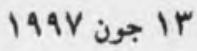

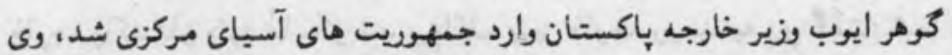

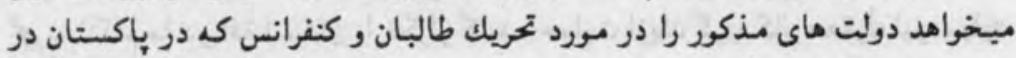

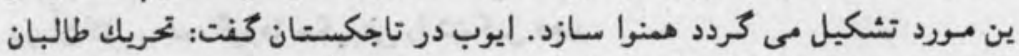

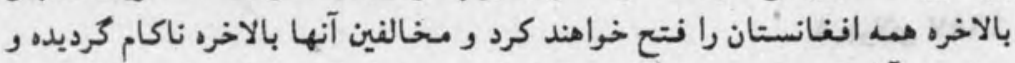

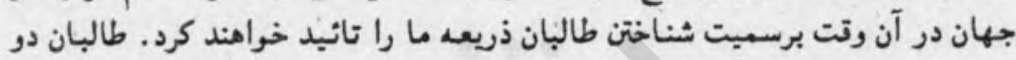
روز تبل دعواى بدست آوردن شهر كندز را نيز نموده بودند.

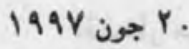

\section{$\Leftrightarrow \&$}

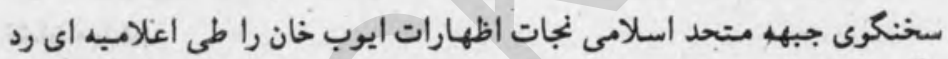

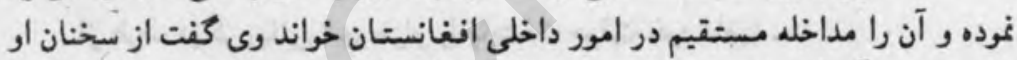

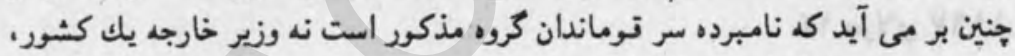
غفورزى نيز سخنان ايوب خان را خلاف موازين واصول مؤسكسه ملل متحد دانست.

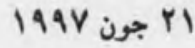

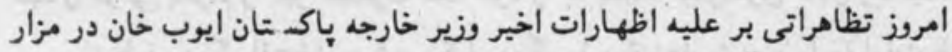

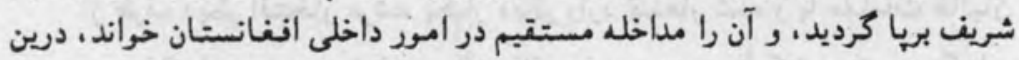

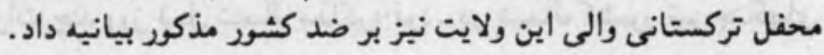

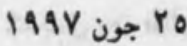

باكستـان كاركنان تونسلكرى خويش از مزار شريف را نرا خواند علت آنرا نا

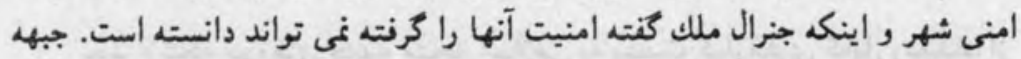

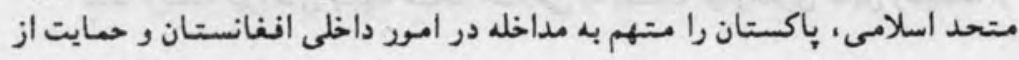


0

$8 \%$

جنگ در جندين ولايت بين طالبان و جبهه متسحد جريان دارد. كوهر ايوب وزير

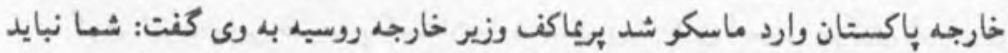

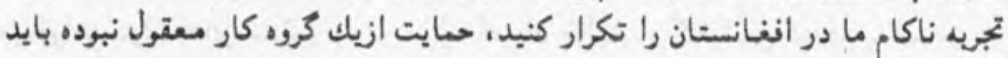

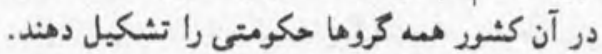

A $199 \sqrt{199}$

$\& \&$

انتخار مرشد نماينده حكومت باكستان كم سر كرم بازديد و مـلاحاتها با سران

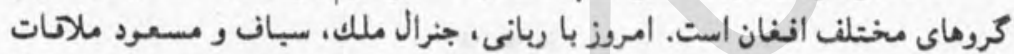

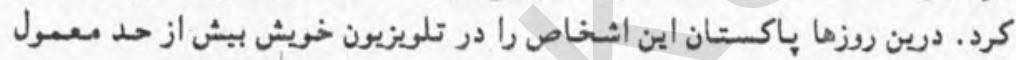

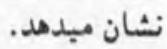

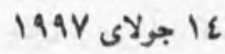

\section{از طرن ديحر ريانى شهر مزار را بايتخت موقت خود نابيد.}

$\& \& \&$

نيروهاى احمدشاه مسعود ولايت يروان را از طالبان دوباره بدست آرردند، امروز مبدان هوانى بحرام را نيز متصرف شده خود را به بنجاه كيلومترى كابل رسانيدند.

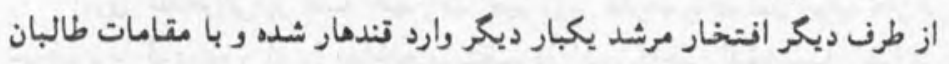

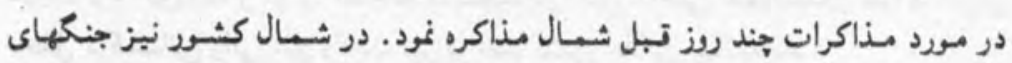

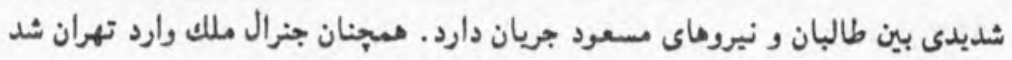

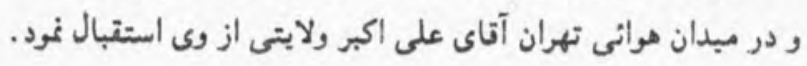

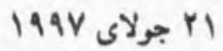

क \&

بعد ازينكه نبروهاى جبهه متحد اسلامى به ببيت كيلومترى كابل رسبلند از 
طالبان خواستند تا كابل را غبر نظامى ساخته و به تشكيل يك خكومت شامل هـ

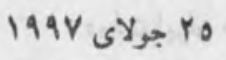

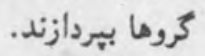

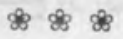

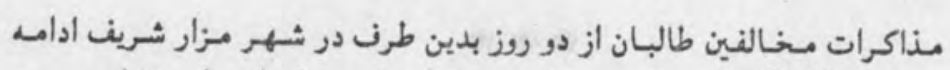

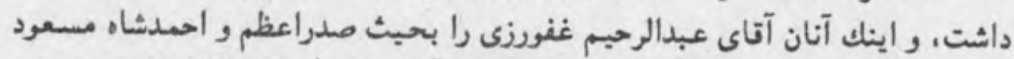

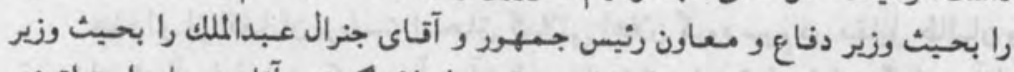

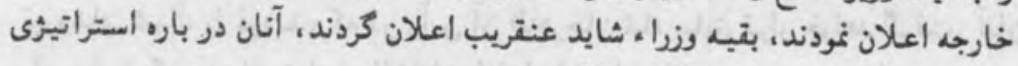
1998 11 19 جديد خويش (حمله بر كابل) نيز مذاكره نمودند.

$\& \%$

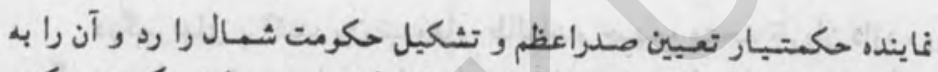

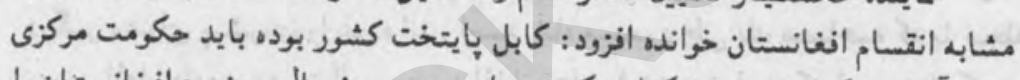

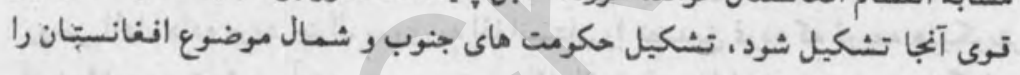

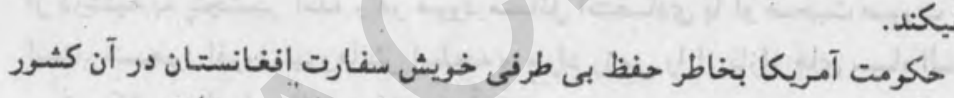
1994 110

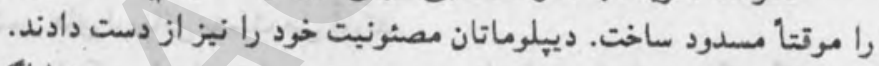

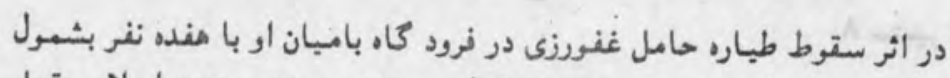

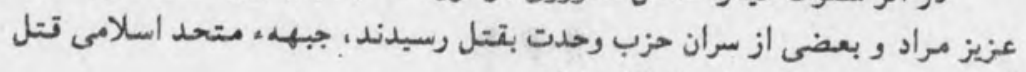

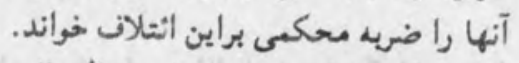

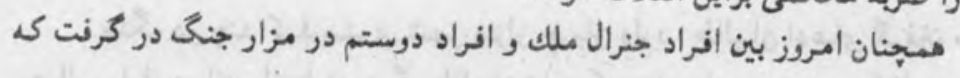

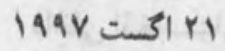
زود وضع بهتر شد.

$\$ 8$

راديوى طالبان اعلان نمود كه يك جاسوس ايرانى را با مواد منفجره در كابل 


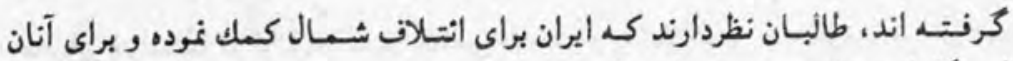
اردوكاهاي در كثور خود ساخته است.

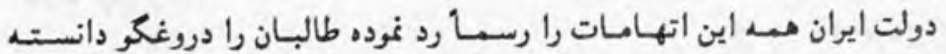
افزودند كد با اين كار ها ميخواهند صلح در آن كشور. قاثم نكردد.

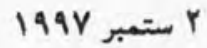

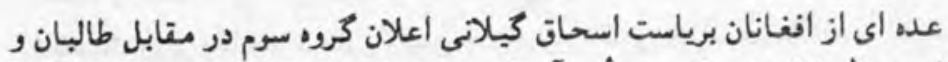

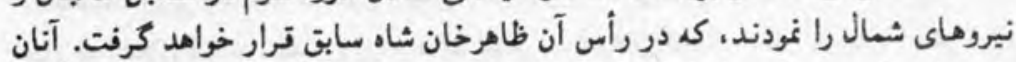
199V ستمبر V باور دارند كه عده ايى زياد از افغانان طرندار اين طرح آندان

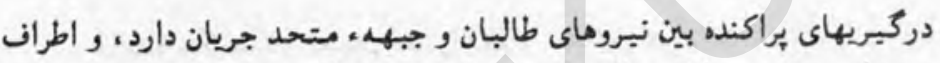

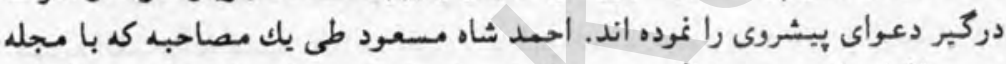

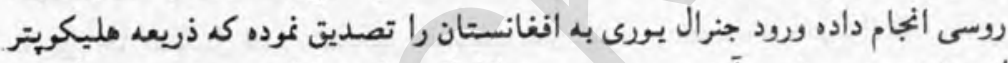

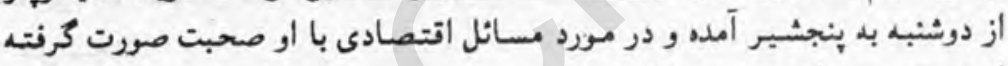

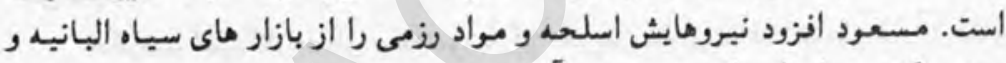
بعضى كشور هاى اروياثى بدست مئى آورند.

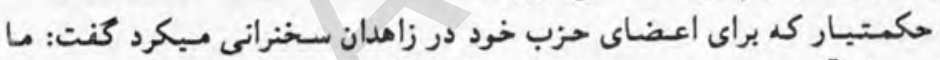

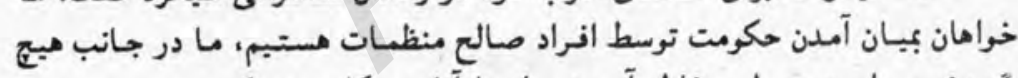

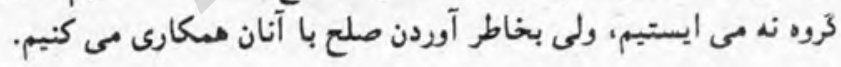

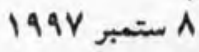

جنگ در جند كيلومترى شهر مزار جريان دارد ، طالبان ادعاى كرفتين مبدان

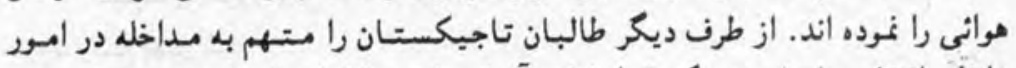

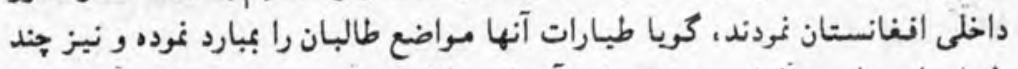

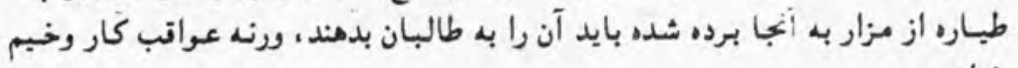

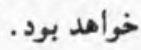
از طرن ديكر نبروهاى مسعود از سمت تخار بر كندز حمله نوده بيشروى نموده 


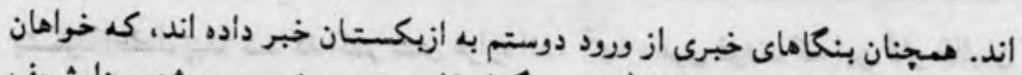

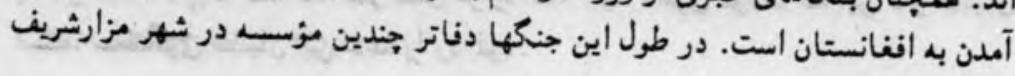
11 | 1994 غارت شده اند.

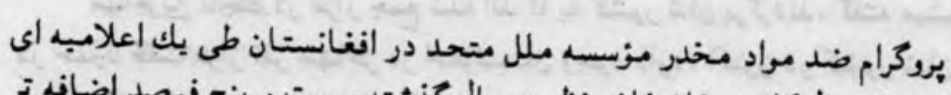

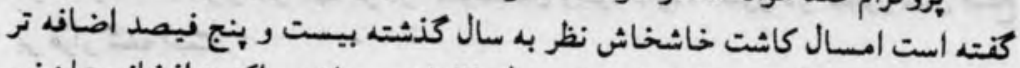

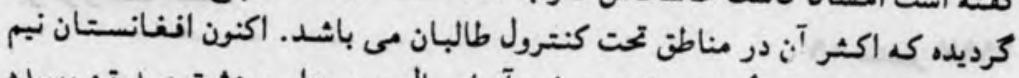

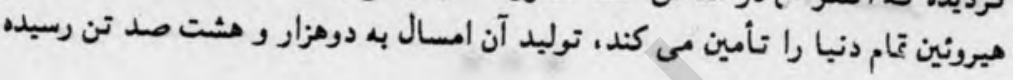

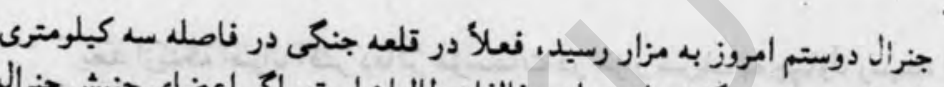

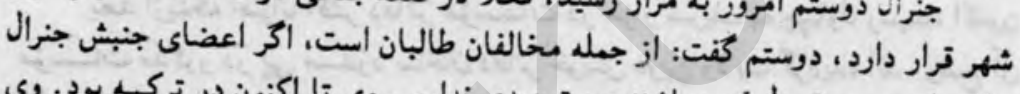

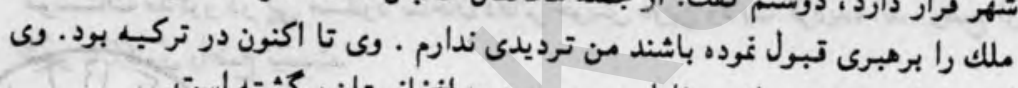
I ا ستمبر 1997

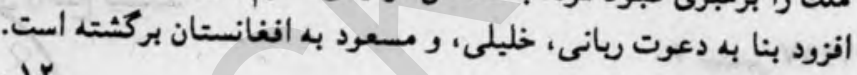

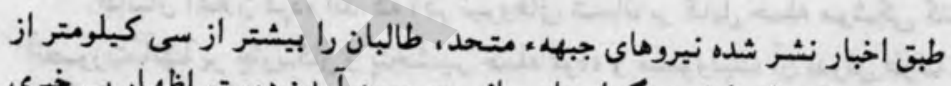

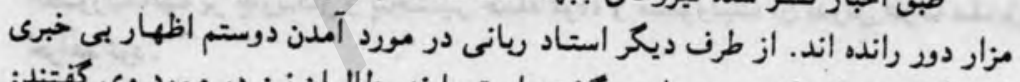

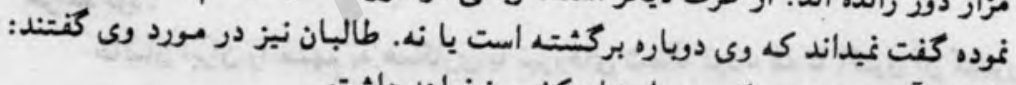
1998 I استعبر

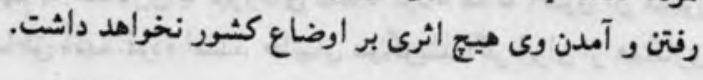

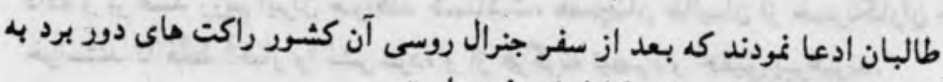
10 ستمبر 1947 مسعود داده كي بر مبدان هواثى كابل فير نموده است.

$\notin \&$

طالبان امروز منطقه مهم حيرتان را تصرن نمودند.

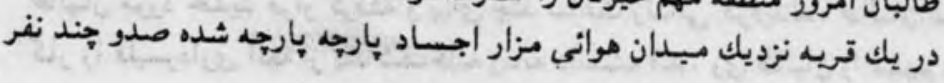


بشـول اطفال يبيدا شـد كه اكثر شان هزاره اند، آنها دعوى نمودند كه اين كار طالبان است، سخنكوى طالبان اين ادعا را رأ رد نمود.

14

مهاجرين تاجك در مزار جمع شده اند تا به كثشور شان بركردند، كنته ميثود كى

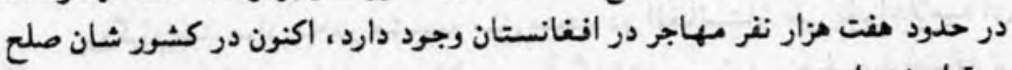
بر ترار شده است. 19

بعد ازينكه اموال اكثر دفاتر موسسات در مزار شريف به جياول رسبد ، اكنون

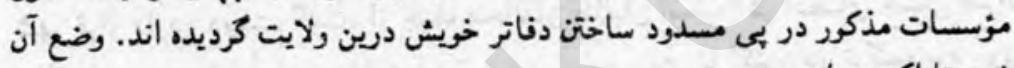
l99V rتمبر r. .

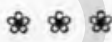

طالبان اعلان نوده اند كم اكر نيروماى شعال بر كنبل حمله موشكى كنند، درو

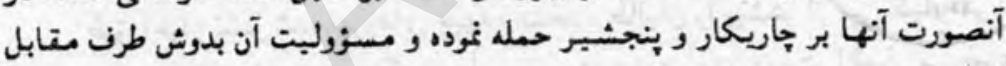
طالبان ايران را متهم به همكارى با نيروهاى شمال نمود، كد تا اكنون آن كشور

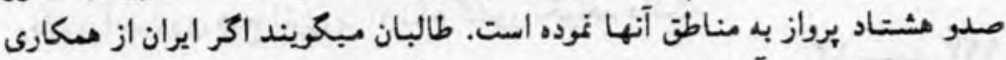

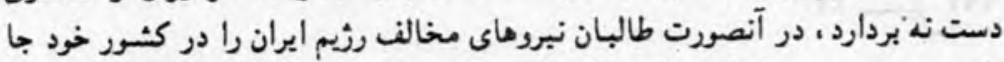

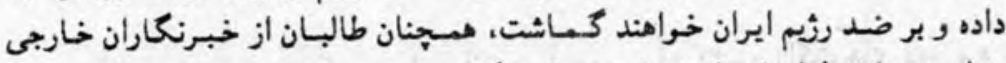

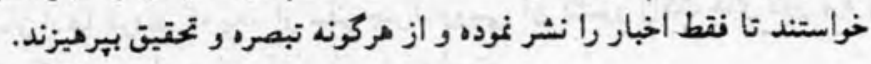
199V Tr

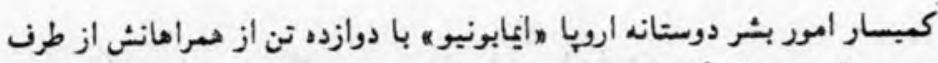

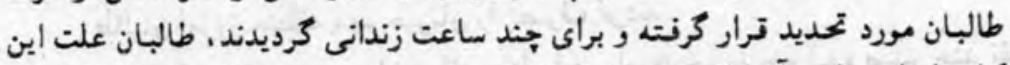

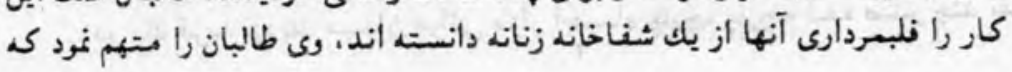




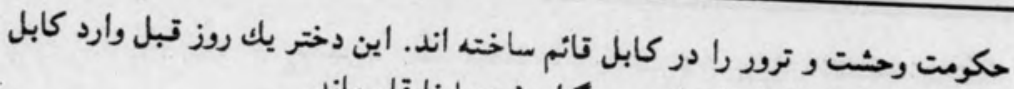
Y99V 1998 شده بود. و اينك كابل را ترك و ورو بروكرام خود ران نا تمام ماند.

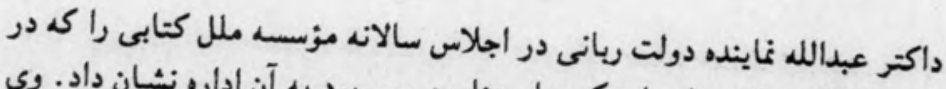

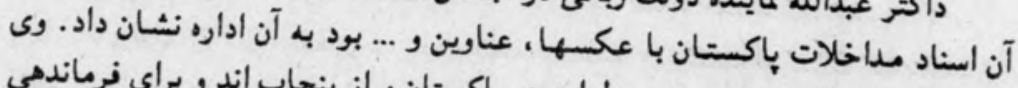

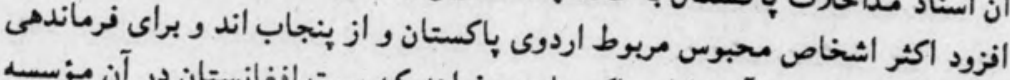

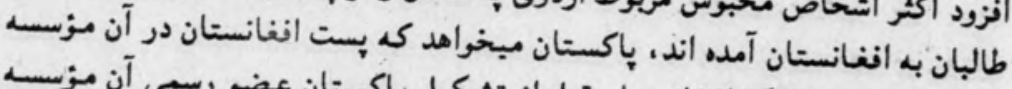

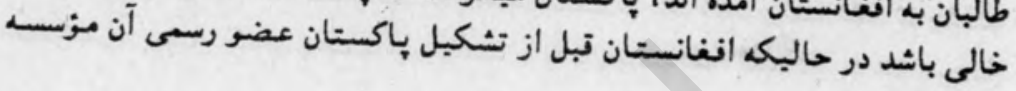
r اكتوبر 1994 بود.

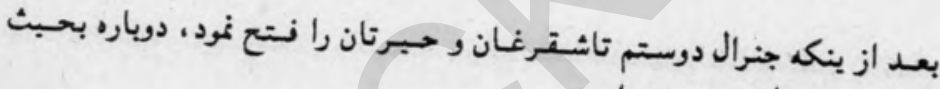

19 اكتوبر 1994 توماندان سمت شمال تعيين شده است.

88

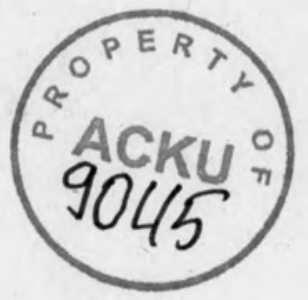



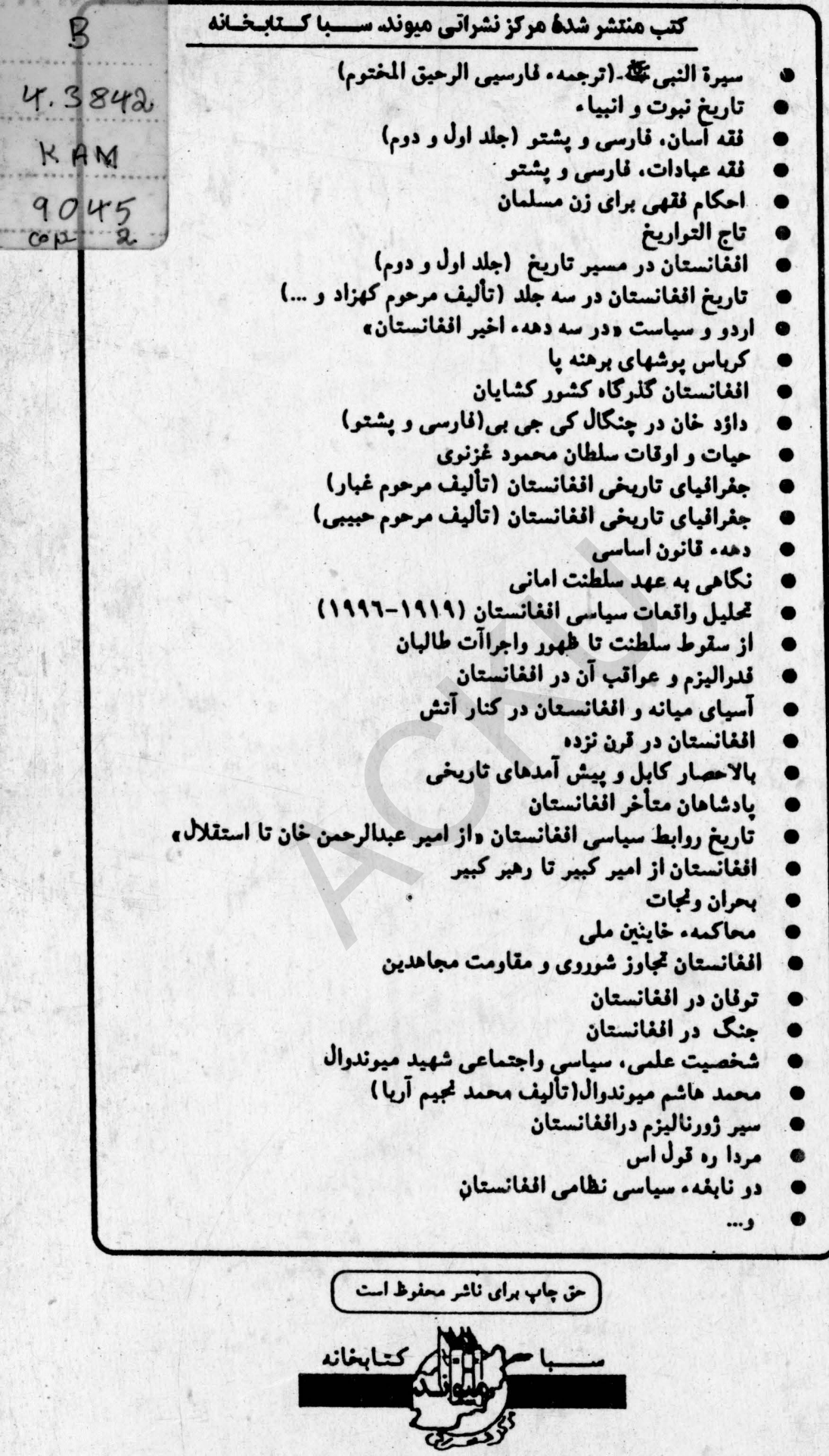

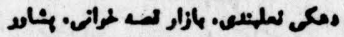

CTAII, Yovoor. sosts 